\title{
CONTROLE DE QUALIDADE POSICIONAL EM DADOS ESPACIAIS UTILIZANDO FEIÇÕES LINEARES
}

\author{
Positional quality control in spatial data using linear feature
}

\author{
AFONSO DE PAULA DOS SANTOS 1 \\ NILCILENE DAS GRAÇAS MEDEIROS 1 \\ GÉRSON RODRIGUES DOS SANTOS 2 \\ DALTO DOMINGOS RODRIGUES ${ }^{1}$ \\ 1 Departamento de Engenharia Civil \\ Setor de Engenharia de Agrimensura e Cartográfica \\ Universidade Federal de Viçosa - Viçosa - MG - Brasil \\ 2 Departamento de Estatística \\ Universidade Federal de Viçosa - Viçosa - MG - Brasil \\ afonso.santos@ufv.br; nilcilene.medeiros@ufv.br; gerson.santos@ufv.br; dalto@ufv.br
}

\section{Resumo:}

Nas últimas duas décadas, o uso de feições lineares tem sido frequentemente investigado no controle de qualidade cartográfica, sendo que diversos métodos foram propostos para tal finalidade. Neste sentido, o presente trabalho tem como objetivo descrever os métodos da Banda Épsilon (Método das Áreas), do Buffer Simples, do Buffer Duplo, da Distância de Hausdorff e da Influência do Vértice na avaliação da acurácia planimétrica através de feições lineares, utilizando como padrão o Decreto-lei $n^{\circ} 89.817$ aliada à ET-ADGV, e ao final, compará-los com o método tradicional por pontos. Para tanto, foi avaliada a acurácia posicional planimétrica de uma ortoimagem Ikonos, onde os resultados obtidos mostraram que os métodos da Banda Épsilon, Distância de Hausdorff e Influência do Vértice apresentaram resultados similares, obtendo-se classificação Classe B na escala 1:10.000. Já os métodos Buffer Simples e Buffer Duplo apresentaram resultados semelhantes ao método tradicional por pontos, que por sua vez, foram mais restritivos que os métodos anteriormente citados, classificando a ortoimagem como Classe C na escala 1:10.000.

Palavras-chave: Controle de Qualidade Cartográfica; Acurácia Posicional; Feição Linear.

\begin{abstract}
:
In the past two decades, the use of linear features has often been investigated in cartographic quality control, and various methods have been proposed for such a purpose. In this sense, this paper aims at describing the methods of the Epsilon Band (areas' method), Simple Buffer,
\end{abstract}


Double Buffer, Hausdorff's Distance and Vertex's Influence in the assessment of planimetric positional accuracy by means of linear features, using as standard the Decree-Law number 89,817 / ET-ADGV, and after this, compare them with the traditional method by points. On the one hand, planimetric positional accuracy was evaluated in a orthoimage Ikonos, where results showed that the methods of the Epsilon Band, Hausdorff's Distance and Vertex's Influence presented similar results, obtaining "class B" rating on the scale 1: 10,000. On the other hand the methods Simple Buffer and Double Buffer presented similar results to traditional method by points, which in turn were more restrictive than the previously mentioned methods, classifying the orthoimage as "Class $C$ " in 1: 10,000 scale.

Keywords: Cartography Quality Control; Positional Accuracy; Linear Feature.

\section{INTRODUÇÃO}

Com a demanda cada vez maior de informações espaciais, cresce a cada dia a disponibilidade de dados espaciais de forma gratuita, equipamentos de medição de fácil utilização e softwares cada vez mais amigáveis. Diante de todo este aparato, fica muito facilitada a manipulação e geração da informação geográfica, o que possibilita que usuários ou empresas, ainda que não detentores de formação técnica especializada em produção cartográfica exerçam tal atividade. É neste sentido que Galo \& Camargo (1994), Santos (2010) e Lunardi et al. (2012) observam que o cuidado com a qualidade, seja ela posicional, geométrica, temporal ou de atributo, pode ser esquecido no processo de análise ou produção de dados espaciais.

Goodchild (2010) ressalta a importância do controle de qualidade ao investigar dados espaciais de modo a garantir e especificar a qualidade e acurácia dos mesmos, explicitando discrepâncias, omissões e incertezas, bem como definindo sua finalidade.

Tanto na avaliação da acurácia posicional em dados cartográficos quanto no processo de representação vetorial cartográfica podem se utilizardas primitivas gráficas: ponto, linha e polígono. Tradicionalmente, em vários países, Normas e Leis têm suas metodologias fundamentadas na comparação entre pontos homólogos pertencentes a diferentes bases cartográficas, sendo que alguns exemplos de pesquisas nessa linha podem ser observados em Ariza (2002), Nogueira Júnior (2003), Nero (2005), Santos (2010), Pereira \& Nero (2012), entre outros. Entretanto, segundo Tong et al. (2013), a investigação de métodos de avaliação daacurácia posicional que utilizam feições lineares tem sido um dos pontos chave nas pesquisas de Sistemas de Informações Geográficas, o que levou a um grande esforço da comunidade científica durante as duas últimas décadas para a compreensão do tema e desenvolvimento de diferentes métodos de avaliação.

Basicamente, os métodos de avaliação da acurácia posicional com o uso de feições lineares consideram a comparação entre linhas homólogas dos dados de teste em relação aos dados de referência. Esta comparação analisa aspectos como: razão entre comprimentos e quantidade de vértices, angularidade, razão de segmentos curvilíneos, distância entre os vértices, percentual de inclusão em uma área de influência, entre outros.

Dentre os métodos existentes, destacam-se: a Banda Épsilon; o Buffer Simples; o Buffer Duplo; a Banda Genérica; o Modelo de Erros Estatístico por Simulação; a Influência do Vértice; o Ponto Gerado; a Distância de Hausdorff; as Aproximações por Spline; o Retângulo Envolvente; a Completude; a Corretude; o RMS modificado; entre outros (Goodchild \& Hunter 1997; Heipke et al. 1997; Galo et al. 2001; Ariza 2002; Vieira et al. 2002; Mozas \& Ariza 2010; Mozas \& Ariza 2011; Tong et al. 2013). 
No Brasil, não é comum o uso de feições lineares para controle de qualidade posicional em dados espaciais. Assim, um questionamento que se apresenta é se a integração dos métodos que utilizam feições lineares com o padrão brasileiro de acurácia posicional (Decreto-lei $\mathrm{n}^{\circ}$ 89.817, Brasil, 1984) resultaria em resultados condizentes aos métodos tradicionais que utilizam feições pontuais.

Diante do exposto, este trabalho tem como objetivo descrever metodologicamente a aplicação dos métodos de avaliação da acurácia posicional planimétrica através de feições lineares, como Banda Épsilon (Método das Áreas), Buffer Simples, Buffer Duplo, Distância de Hausdorff e Influência do Vértice; utilizando como padrão o Decreto-lei n ${ }^{\circ}$ 89.817. Bem como, a realização da comparação dos resultados obtidos da aplicação dos distintos métodos de feições lineares com o método tradicional por pontos.

Uma das principais justificativas para a investigação de incertezas em base de dados espaciais utilizando feições lineares é o fato de que: (i) $80 \%$ dos dados presentes em uma base cartográfica tem como estrutura a primitiva gráfica linha; (ii) geralmente as feições lineares têm uma boa distribuição espacial nas bases cartográficas como redes de rodovias e hidrografia e; (iii) os elementos lineares apresentam uma grande quantidade de informação geométrica como vértices, segmentos, orientação, entre outros (Mozas e Ariza 2011).

Habib et al. (2004) citam que o uso de feições lineares é atrativo, já que feições retas são mais fáceis de serem identificadas e extraídas na imagem, tanto visualmente, quanto automaticamente.

\section{O PADRÃO BRASILEIRO DE ACURÁCIA POSICIONAL}

Percebe-se que existem diversos métodos de avaliação da acurácia posicional que utilizam feições pontuais, sendo que todos eles são similares no fato de realizar a comparação entre a amostra de pontos de checagem obtida em campo ou em algum dado espacial mais acurado, com a amostra de pontos homólogos no dado espacial em avaliação. A partir desta comparação, diversas formulações e testes estatísticos são aplicados de acordo com a norma de acurácia posicional utilizada.

Neste trabalho será abordada a avaliação da acurácia posicional utilizando o padrão nacional definido pelo Decreto-lei n ${ }^{\circ}$ 89.817, de 1984, aliado à Especificação Técnica de Aquisição de Dados Geoespaciais Vetoriais (ET-ADGV), de 2011 (BRASIL 1984; DSG 2011). A ETADGV, é uma especificação técnica associada à Infraestrutura Nacional de Dados Espaciais (INDE) com intuito de padronizar e orientar o processo de aquisição da geometria dos vários tipos de dados geoespaciais vetoriais (DSG 2011). Em um de seus itens, a ET-ADGV explica como deve ser a aplicação do Decreto-lei $n^{\circ} .89 .817$ e cria uma classe mais restritiva destinadas para produtos cartográficos digitais (PEC-PCD).

No Decreto-lei 89.817 está implícito que os dados de discrepâncias posicionais sigam a distribuição normal. Portanto, no presente estudo, para se utilizar o padrão de acurácia posicional do Decreto-lei $\mathrm{n}^{\circ} 89.817$ / ET-ADGV, deve-se antes atestar a normalidade da amostra de discrepâncias posicionais.

Conforme se observa na literatura especializada, principalmente (Mood et al. 1974), os testes de normalidade univariada pressupõem a independência estatística dos dados, sendo que, para inferir sobre a independência estatística de um conjunto de dados, pode-se utilizar o teste do Qui-Quadrado. Depois de verificada a independência, torna-se viável a aplicação de testes de normalidade, como Shapiro-Wilk, Komolgorov-Smirnov, Anderson-Darling, Qui-Quadrado, entre outros. 
Segundo BRASIL (1984), Santos (2010) e DSG (2011), para que um produto cartográfico seja classificado quanto ao Decreto-lei 89.817, o mesmo deve atender duas condições: (i) $90 \%$ dos pontos testados devem apresentar valores de discrepâncias iguais ou inferiores ao valor do PEC em relação à escala e a classe testada e; (ii) o RMS (root mean square) das discrepâncias deve ser igual ou inferior à tolerância EP definido pela norma (Tabela 1).

Tabela 1: Tolerâncias utilizadas para avaliação da acurácia posicional planimétrica utilizando o Decreto-lei no 89.817 aliada à ET-ADGV.

\begin{tabular}{c|c|c|c}
\hline Classe & Classe & \multicolumn{2}{|c}{ Planimetria } \\
\cline { 3 - 4 } PEC & PEC-PCD & PEC & EP* \\
\hline- & A & $0,28 \mathrm{~mm}$ & $0,17 \mathrm{~mm}$ \\
\hline A & B & $0,5 \mathrm{~mm}$ & $0,3 \mathrm{~mm}$ \\
\hline B & C & $0,8 \mathrm{~mm}$ & $0,5 \mathrm{~mm}$ \\
\hline C & D & $1,0 \mathrm{~mm}$ & $0,6 \mathrm{~mm}$ \\
\hline
\end{tabular}

* EP é uma tolerância chamada “erro-padrão" de acordo a nomenclatura do Decreto-lei n 89.817 .

A discrepância planimétrica, descrita pela equação 01, é obtida pela resultante posicional entre as coordenadas de campo ou referência $\left(\mathrm{X}_{\mathrm{R}}, \mathrm{Y}_{\mathrm{R}}\right)$ com as coordenadas do dado espacial em teste $\left(\mathrm{X}_{\mathrm{T}}, \mathrm{Y}_{\mathrm{T}}\right)$. Já o RMS das discrepâncias é definido pela equação 02.

$$
\begin{array}{r}
d_{p}=\sqrt{\left(X_{T}-X_{R}\right)^{2}+\left(Y_{T}-Y_{R}\right)^{2}} \\
R M S_{d}=\sqrt{\frac{\sum_{i=1}^{n}\left(d_{p_{i}}\right)^{2}}{n-1}}
\end{array}
$$

\section{MÉTODOS DE AVALIAÇÃO DA ACURÁCIA POSICIONAL QUE UTILIZAM FEIÇÕES LINEARES}

Existem vários métodos de controle de qualidade cartográfica que utilizam feições lineares, muito embora não sejam freqüentes sua divulgação e estudos mais aprofundados no Brasil. A grande maioria destes métodos foi criada com o objetivo de avaliar os resultados do processo/método de generalização cartográfica.

Podem-se dividir os métodos de feições lineares em três grupos principais:

i. Grupo de faixa de incerteza que utilizam uma abordagem determinística, como o método da Banda Épsilon ou Método das Áreas, Buffer Simples e Buffer Duplo.

ii. Grupo de faixa de incerteza utilizando uma abordagem estocástica, como a Banda Genérica e Modelo de Erros Estatístico por Simulação;

iii. Grupo de métodos determinísticos que realizam análises geométricas, como a Distância de Hausdorff, Influência do Vértice, Aproximação por Spline e Ponto Gerado.

O modelo de faixa de incerteza ou Banda de Erro, como é conhecido, é uma faixa ao redor da posição de referência (tida como a posição mais provável) de uma feição espacial. Perkal (1966) criou o modelo da faixa de incerteza que consiste em gerar um buffer ao redor do segmento de linha, sendo esta área utilizada para representar a incerteza posicional da feição linear.

Em seguida serão detalhados alguns métodos do grupo (i) (Banda Épsilon, Buffer Simples e Buffer Duplo) e do grupo (iii) (Distância de Hausdorff e Influência do Vértice) que foram utilizados neste trabalho. Estes métodos foram escolhidos devido a facilidade de implementação em um ambiente de Sistemas de Informações Geográficas. 


\subsection{Banda Épsilon ou Método das Áreas}

O modelo da banda (ou faixa) de incerteza tem sido a base para diversos estudos e métodos de avaliação da acurácia posicional em dados espaciais.

Masry et al. (1980) e Blakemore (1984) adaptaram o método proposto por Perkal (1966), chamando-o de Banda Épsilon $(\mathcal{E}$-band). Este consiste em gerar uma medida de discrepância posicional $(\varepsilon)$ entre duas feições lineares através da razão entre o somatório das áreas $(A)$ formadas pela sobreposição de ambas as linhas e o comprimento da linha testada $\left(L_{T}\right)$ (ver equação 3 e Figura 1). Este método foi utilizado por Lugnani (1986), Galo et al. (2001) e Vieira et al. (2002), sendo chamado de Método das Áreas.

Segundo Tong et al. (2013), a banda Épsilon é uma região de discrepância em torno da linha de teste com uma largura constante em cada lado da linha. No entanto, a Banda Épsilon é um modelo de erro determinístico que assume que essa discrepância é uniforme em largura e que a linha tida como referência se localiza dentro da região dessa banda.

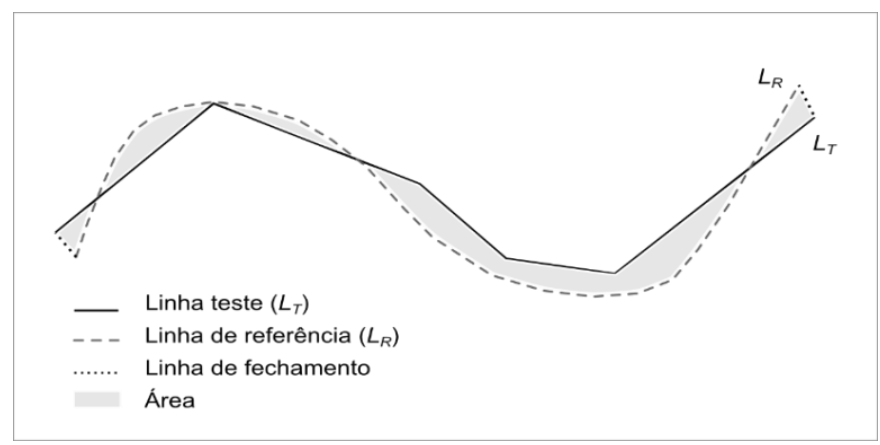

Figura 1: Forma de comparar duas feições lineares através do método da banda de erro épsilon.

Para aplicação do método da Banda de Erro Épsilon ou Método das Áreas, utilizam-se das seguintes etapas:

1. Selecionar uma amostra contendo $n$ linhas homólogas de teste $\left(L_{T}\right)$ e de referência $\left(L_{R}\right)$;

2. Sobrepor as linhas de teste com as de referência, se os pontos extremos das linhas homólogas de teste e de referência não se coincidirem, criar um segmento de reta unindo-os (linha de fechamento);

3. Obter o somatório das áreas internas (unidades $\mathrm{m}^{2}$ ), criadas pela sobreposição das linhas homologas de teste e referência (Figura 1), para cada elemento $i$ pertencente à amostra de linhas homólogas;

4. Obter o comprimento (em metros) de cada linha $i$ de teste $\left(C L_{T}\right)$;

5. Calcular a Banda de Erro Épsilon $(\varepsilon)$, para cada elemento $i$ da amostra, dividindo o somatório das áreas internas pelo comprimento da linha teste:

$$
\varepsilon_{i}=\frac{\left(\sum A\right)_{i}}{C L_{T i}}
$$

6. Ao final, analisa-se a medida de discrepância, obtida pelo valor da Banda de Erro Épsilon, com a norma ou padrão de acurácia utilizado. Para a aplicação do Decreto-lei $\mathrm{n}^{\circ} 89.817$, sugere-se verificar a independência e normalidade e, se constatada, pelo menos $90 \%$ das linhas testadas deverão apresentar valor de $\varepsilon$ menor ou igual ao valor do PEC, bem como o RMS da amostra de $\varepsilon$ ser menor ou igual ao valor de EP, para a classe e escala utilizada. 


\subsection{Buffer Simples}

Goodchild \& Hunter (1997) desenvolveram um método para determinar a largura da Banda de Erro. Nesta metodologia, a referida largura é calculada através da proporção da linha testada que se encontra dentro de um buffer gerado na linha de referência. Portanto, a largura da banda de erro é definida quando a proporção de inclusão da linha testada atinge uma tolerância prédefinida (usualmente $90 \%$ ou 95\%). Os autores chamam este método de Buffer Simples (Simple Buffer method), embora existam em outras bibliografias autores citando o método com o nome de Buffer Overlay. Segundo Shi (2010) este método, modificado da Banda Épsilon, é mais apropriado que o método anterior quando comparados à sensibilidade de erros grosseiros (outliers) na feição linear.

Portanto, o método do Buffer Simples baseia-se na geração de um buffer na linha de referência $\left(B_{R}\right)$ e, em seguida, avalia-se a porcentagem de inclusão da linha testada $\left(L_{T}\right)$ dentro deste buffer (Figura 2). Esta porcentagem de inclusão é utilizada como uma medida de discrepância entre as duas linhas (equação 4).

Ao aumentar a largura do buffer, pode-se obter uma distribuição de probabilidade de inclusão da linha teste no buffer da linha de referência, conforme Figura 3.

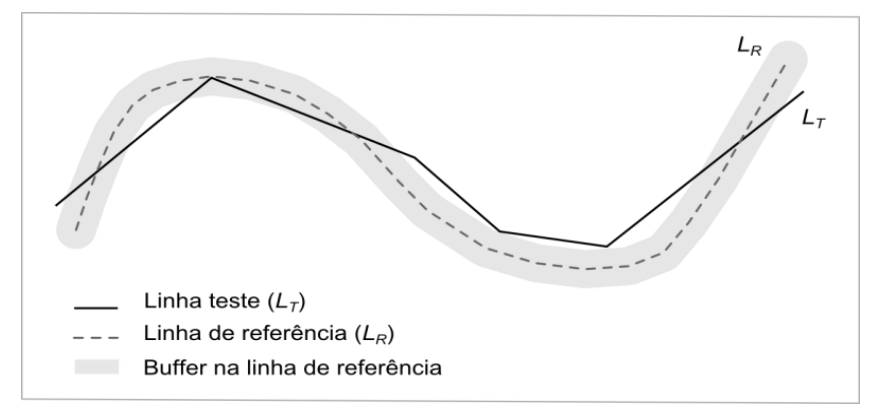

Figura 2: Forma de comparar duas feições lineares através do método do Buffer Simples.

Para a aplicação do método do Buffer Simples, utilizam-se as seguintes etapas:

1. Selecionar uma amostra de $n$ linhas homólogas de teste $\left(L_{T}\right)$ e de referência $\left(L_{R}\right)$;

2. Calcular o comprimento (em metros) de cada linha $i$ da amostra de teste $\left(C L_{T}\right)$;

3. Criar um buffer de tamanho $x$, em metros, para cada linha $i$ da amostra de referência. Para a aplicação do Decreto-lei $n^{\circ} 89.817$, utiliza-se como tamanho do buffer o valor do PEC para a escala e a classe utilizada no processo de avaliação;

4. Fazer uma interseção entre as linhas homólogas de teste e os polígonos gerados, pelo buffer $x$, nas linhas de referências;

5. Calcular o comprimento, em metros, para cada linha teste resultante da interseção $\left(C L_{X}\right)$;

6. Calcular o percentual $(p(x))$ de inclusão de cada linha teste dentro da área do buffer $x$ correspondente. O percentual é calculado através da razão entre o comprimento da linha inclusa e o comprimento total da linha testada.

$$
p(x)_{i}=\frac{C L_{x_{i}}}{C L_{T_{i}}}
$$

7. Para análise do Decreto-lei $n^{\circ} 89.817$, verifica-se a independência e normalidade da amostra de discrepâncias e, caso afirmativo, faz-se a análise se $90 \%$ das linhas testadas apresentam percentual maior ou igual a 0.9 (90\%), classificando o dado espacial de acordo com a classe e a escala trabalhada. 


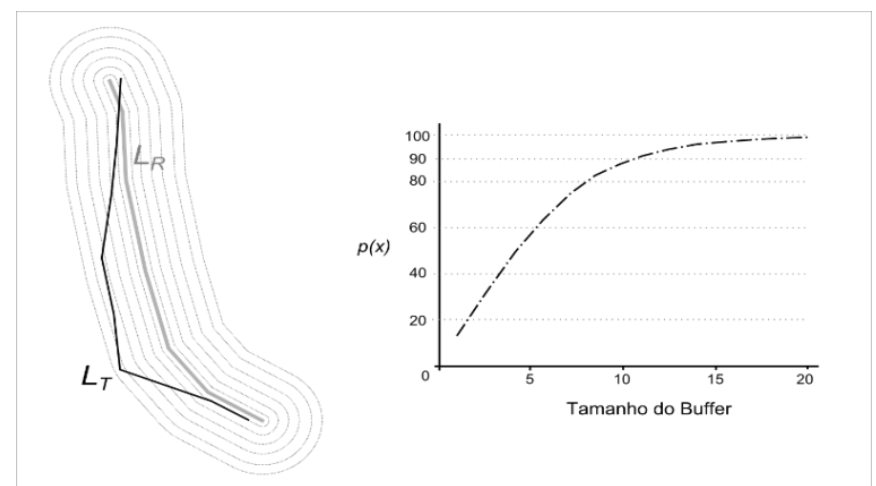

Figura 3: Percentual de inclusão da linha teste no buffer da linha de referência. Fonte: Adaptado de Ariza \& Mozas (2005).

Conforme Atkinson \& Ariza (2002), o método do Buffer Simples é de fácil implementação em um SIG. Por outro lado, não há possibilidade de detectar erros sistemáticos na linha teste, já que não se sabe em qual lado está posicionada a linha de referência em relação à de teste.

Um método similar ao Buffer Simples, com denominação de Corretude, foi sugerido por Heipke et al. (1997) para a avaliação de métodos automáticos de extração de feições lineares em imagens. Outro método sugerido pelos mesmos autores é a Completude, no qual se calcula a porcentagem da linha de referência que se encontra dentro de um buffer gerado na linha teste.

\subsection{Buffer Duplo}

Tveite \& Langaas (1999) propuseram o método chamado de Buffer Overlay Statistics, como um aprimoramento do método do Buffer Simples. Esta técnica consiste em aplicar o modelo da Banda de Erro tanto na linha de referência quanto na linha a ser testada. Portanto, aplica-se um buffer em ambas as linhas, e em seguida é realizada uma interseção entre os polígonos resultantes dos buffers (Figura 4), de modo a obter uma medida de discrepância média entre as feições lineares.Assim, é possível avaliar posicionalmente a acurácia do dado espacial em teste. Dessa maneira, como no método do Buffer Simples, pode-se gerar pelo método do Buffer Duplo um gráfico da discrepância média em relação à largura do buffer.

Atkinson \& Ariza (2002) afirmam que o método é similar ao método do Buffer Simples, embora haja alguns ganhos nas análises de resultados. Exemplo disso é o cálculo de uma medida de discrepância (equação 5) que pode ser aplicada a um teste de tendência para a verificação de erros sistemáticos. A discrepância $(d m)$ pode ser obtida multiplicando-se o valor de pi $(\pi)$ pela largura do buffer $(x)$ e pelo somatório da área do buffer da linha de referência que não faz interseção com o buffer da linha de teste $\left(A_{F}\right)$ dividido pelo valor da área formada pelo buffer da linha teste $\left(A_{T}\right)$.

$$
d m_{i}=\pi \cdot x \cdot \frac{\left(\sum A_{F}\right)_{i}}{A_{T_{i}}}
$$




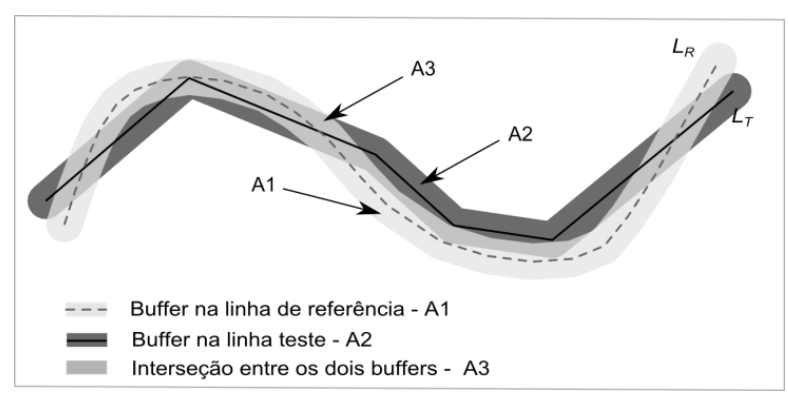

Figura 4: Método Buffer Duplo.

Para a aplicação do Buffer Duplo, utilizam-se as seguintes etapas:

1. Selecionar uma amostra de $n$ linhas homólogas de teste $\left(L_{T}\right)$ e de referência $\left(L_{R}\right)$;

2. Aplicar um buffer de tamanho $x$ em cada linha $i$ da amostra de linhas homólogas de teste e referência. Para o emprego do Decreto-lei $\mathrm{n}^{\circ}$ 89.817, utiliza-se como tamanho do buffer o valor do PEC para a escala e a classe utilizada no processo de avaliação;

3. Calcular a área $A_{T}$ gerada pela operação de buffer em cada linha de teste.

4. Fazer uma sobreposição entre os polígonos gerados pelos buffers da linha teste e da linha de referência e calcular o valor de $A_{F}$, referente a área do polígono de referência que não faz interseção ao polígono teste;

5. Calcular a discrepância média $(d m)$, para cada linha teste $i$ (equação 5);

6. Para análise do Decreto-lei $\mathrm{n}^{\circ}$ 89.817, sugere-se verificar a independência e normalidade e, se constatada, faz-se a análise se $90 \%$ das linhas testadas apresentam discrepância média $(d m)$ menor ou igual ao valor do PEC (da classe e escala utilizados para gerar o buffer $x$ ), e ainda, o RMS das discrepâncias dm ser menor ou igual ao valor do EP (idem ao PEC). Se as duas condições forem aceitas, classifica-se o dado espacial de acordo com a classe e escala trabalhada.

\subsection{Distância de Hausdorff}

Este método, desenvolvido por Abbas (1994), consiste em determinar a Distância de Hausdorff sobre pares de linhas homólogas. A Distância de Hausdorff $(d h)$ consiste em obter o máximo valor das menores distâncias euclidianas entre duas linhas (Figura 5).

Segundo Ariza \& Mozas (2011), a Distância de Hausdorff é utilizada para recuperação de informação e análise de similaridades entre objetos vetoriais e imagens. Para avaliar a acurácia posicional, aplica-se esta distância às feições lineares, obtendo assim a medida de discrepância da linha testada.

Ariza (2002) explica que para a aplicação deste método deve-se obter a distância máxima das menores distâncias de cada linha teste em relação à linha de referência $(d l)$, e a distância máxima das menores distâncias de cada linha de referência em relação à linha teste $(d 2)$. Ao final, o maior valor entre $d 1$ e $d 2$ será a Distância de Hausdorff $(d h)$.

$$
d h=\max [d 1, d 2]
$$

Sabe-se que a Distância de Hausdorff é muito sensível a erros grosseiros ou ruídos, existindo vários métodos modificando a Distância de Hausdorff de modo a evitar este problema. Segundo Ariza (2002), os valores de distâncias obtidos são inadequados para utilizá-los como discrepâncias entre as linhas devido às diferenças de tamanhos, forma, complexidade, números de segmentos, entre outros fatores. Abbas (1994) propõe a eliminação destes problemas 
realizando uma normalização das distâncias $d 1, d 2$ e $d h$, de modo a dividir estas por $d 1 o, d 2 o$ e dho respectivamente. Estes últimos valores citados são obtidos para cada par de objetos através de uma simulação baseada na perturbação dos vértices das linhas com valores de RMS determinados a priori e multiplicados pela discrepância a priori. Após a normalização calculase o percentual de similaridade entre as duas linhas e o valor do RMS.

Mozas (2007) sugere utilizar como valor de $d 1$ e $d 2$ a média das menores distâncias entre os vértices da linha teste com relação à linha de referência, e vice-versa. Em seguida, o maior valor entre $d 1$ e $d 2$ será a Distância de Hausdorff. Este processo substitui o processo de normalização dos valores $d h$, citado anteriormente. Aplicando-se este método em linhas sintéticas, o autor obteve resultados similares ao método da Banda Épsilon (Método das Áreas).

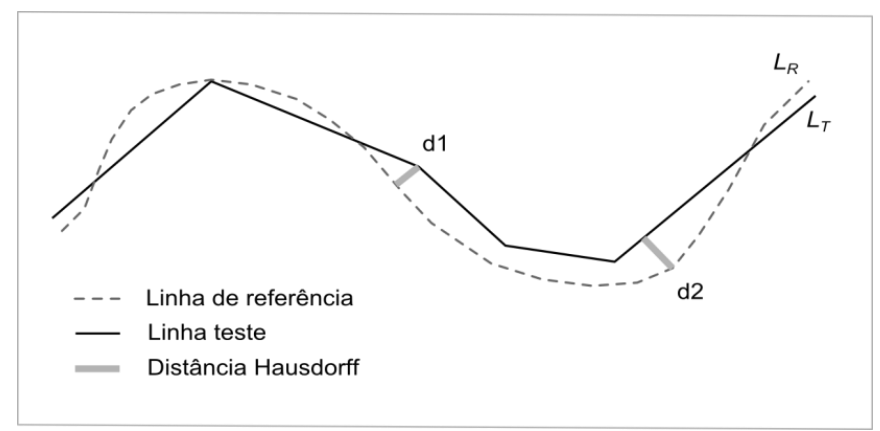

Figura 5: Distância de Hausdorff.

Para aplicação do método Distância de Hausdorff, utilizam-se as seguintes etapas:

1. Selecionar uma amostra de $n$ linhas homólogas de teste $\left(L_{T}\right)$ e de referência $\left(L_{R}\right)$;

2. Extrair os vértices das linhas teste e da linha de referência;

3. Calcular a menor distância de cada vértice da linha teste em relação a qualquer segmento da linha de referência. Obter a média de todas as menores distâncias calculadas, atribuindo o valor a $d l$;

4. Calcular a menor distância de cada vértice da linha de referência em relação a qualquer segmento da linha teste. Obter a média de todas as menores distâncias calculadas, atribuindo o valor a $d 2$;

5. A Distância de Hausdorff (dh) é definida pelo maior valor de $d 1$ e $d 2$;

6. Para a análise deste método junto ao Decreto-lei ${ }^{\circ} 89.817$, verifica-se a independência e normalidade e, se constatada, utiliza-se o valor de $d h$ como medida de discrepância. Portanto, para ser classificado deve-se atender a duas condições: $90 \%$ de $d h$ ser menor ou igual ao valor do PEC e; o RMS da amostra de $d h$ ser menor ou igual ao valor do EP para a classe e escala empregada.

\subsection{Influência do Vértice}

Mozas \& Ariza (2011) afirmam que as feições lineares contidas em uma base de dados cartográfica geralmente são obtidas pelo processo de vetorização, digitalização, restituição ou extração automática. Durante estes processos, as linhas são definidas por um conjunto de vértices, sendo estes os elementos estruturais da linha. Assim, os mesmos autores consideram que os vértices devem ser os elementos prioritários para o controle de qualidade posicional ao se utilizar feições lineares. Isto é reforçado por modelos de incertezas como a faixa ou banda de erro, que definem o valor máximo da incerteza nos extremos de um segmento de reta (locais onde estão os vértices) e mínimo no centro do segmento. 
Segundo os autores do método Mozas \& Ariza (2011), em uma feição linear cada vértice de uma linha determina a posição (alinhamento) dos dois segmentos de retas adjacentes. Pode-se pensar em utilizar um método de feições pontuais através dos vértices, mas os autores afirmam que este método não seria sensível ao cruzamento dos segmentos de retas.

Portanto, o método baseia-se na medição da distância euclidiana a partir dos vértices da linha de referência $\left(L_{R}\right)$ para a linha teste $\left(L_{T}\right)$. Estas distâncias são ponderadas em função do comprimento dos segmentos adjacentes ao vértice aplicado. Assim, obtém-se o valor ponderado das distâncias entre os vértices de referência para a linha teste.

Logo, para o conjunto completo de linhas propõe-se o cálculo da média aritmética ponderada usando o comprimento das linhas (peso), para obter o valor da discrepância média $(D)$ entre as duas linhas, conforme equação 7 e Figura 6.a.

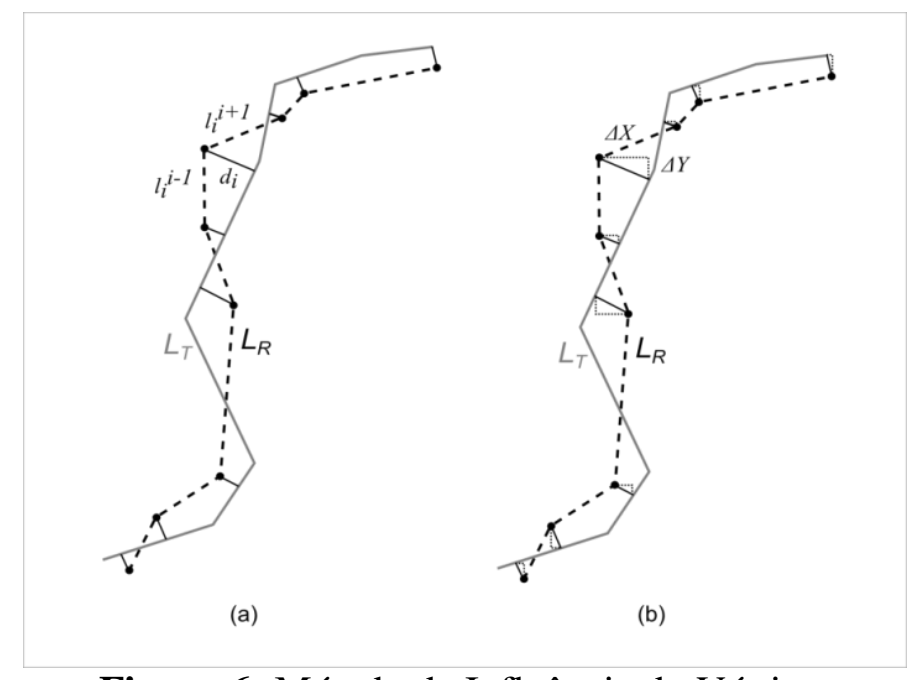

Figura 6: Método da Influência do Vértice.

Fonte: Adaptado de Mozas \& Ariza (2011).

Os autores ainda propõem realizar a análise de tendência nos dados de duas formas: a primeira aplicando o teste $\mathrm{t}$ de Student baseado nas componentes $(\Delta x, \Delta y)$ de cada distância analisada (Figura 6.b); ou tendo como base a obtenção da média ponderada das componentes analisadas em relação ao comprimento dos seguimentos adjacentes, conforme equação 8 .

$$
\begin{aligned}
& D_{i}=\frac{\left[\sum_{k=1}^{m}\left(d h_{k} \cdot\left(l_{k}^{k-1}+l_{k}^{k+1}\right)\right)\right]_{i}}{2 \cdot C L_{R_{i}}} \\
& \bar{\Delta}_{(x, y)_{i}}=\frac{\left[\sum_{k=1}^{m}\left(\Delta_{(x, y)} \cdot\left(l_{k}^{k-1}+l_{k}^{k+1}\right)\right)\right]_{i}}{2 \cdot C L_{R_{i}}}
\end{aligned}
$$

onde:

$m$ : número de vértices da linha de referência;

$d h_{k}$ : distância horizontal mínima entre o vértice $k$ de $R$ para $T$;

$l_{k-1}$ e $l_{k+1}$ : comprimento dos seguimentos adjacentes ao vértice $k$ em $R$;

$C L_{R}$ : comprimento da feição linear de referência;

$\Delta$ : componente analisada ( $\Delta X$ e $\Delta Y$ ) da distância do vértice $k$ em $R$ para $T$;

Para a aplicação do método da Influência do Vértice, utilizando o padrão de acurácia posicional brasileiro, utilizaram-se as seguintes etapas:

1. Selecionar uma amostra de $n$ linhas homólogas de teste $\left(L_{T}\right)$ e de referência $\left(L_{R}\right)$; 
2. Calcular o comprimento $\left(C L_{R}\right)$ e extrair os vértices de cada linhai de referência;

3. Calcular a menor distância $\left(d h_{k}\right)$ para cada vérticek da linha referência em relação a qualquer segmento da linha teste.

4. Obter os valores dos comprimentos dos segmentos de retas anteriores $\left(l_{k-1}\right)$ e posteriores $\left(l_{k+1}\right)$ aos vértices $k$ da linha $i$ de referência;

5. Calcular a discrepância média $(D)$ para cada linha $i$ de referência (equação 7);

6. Para o dado espacial ser classificado de acordo com o Decreto-Lei ${ }^{\circ} 89.817$, verificase a independência e normalidade; caso afirmativo, $90 \%$ de $D$ tem que ser menor ou igual que o valor do PEC e o RMS de $D$ tem que ser menor ou igual ao valor do EP, para a classe e escala empregadas no processo de avaliação da acurácia posicional

\section{EXPERIMENTOS E RESULTADOS}

Para a aplicação e posterior comparação dos métodos de avaliação da acurácia posicional baseados no uso de feições lineares e feições pontuais, avaliou-se a acurácia posicional planimétrica de uma ortoimagem Ikonos.

Aplicaram-se os métodos de feição linear da Banda Épsilon (Método das Áreas), Buffer Simples, Buffer Duplo, Distância de Hausdorff e Influência do Vértice; utilizando-se a metodologia descrita na seção 3, sendo esta implementada no software ArcGIS utilizando da ferramenta Model Builder. O método de feições pontuais foi utilizado conforme metodologia descrita na seção 2.

A área de estudo compreendeu parte do município de Viçosa, no estado de Minas Gerais, contendo a sub-bacia do ribeirão São Bartolomeu, que integra a bacia hidrográfica do Rio Doce. Possui uma área de $134 \mathrm{~km}^{2}$, delimitada pelas latitudes $20,73^{\circ} \mathrm{S}$ e $20,84^{\circ} \mathrm{S}$, e longitudes $42,82^{\circ} \mathrm{W}$ a $42,92^{\circ} \mathrm{W}$. Tem altitudes variando de 600 a 900 metros, apresentando relevo montanhoso.

A imagem avaliada é proveniente do satélite Ikonos II, produto Geo Ortho Kit pan-sharpened, na qual as imagens multiespectrais (resolução espacial de 4 metros) e a imagem pancromática (resolução espacial de 1 metro) são fusionadas. Após fusão, a imagem Ikonos foi submetida a um processo de ortorretificação, através do software PCI Geomatics 10, com modelos matemáticos baseados nas transformações racionais polinomiais, com o uso de RPCs (Rational Polinomial Coeficients), sem o emprego de pontos de controle. Na ortorretificação utilizou-se um MDE advindo de dados das cartas topográficas na escala de 1:50.000 do mapeamento sistemático brasileiro.

De posse da ortoimagem a ser avaliada, foram coletadas em campo 14 estradas (totalizando 46,2 km) e 23 pontos de checagem, conforme ilustrado pela Figura 7. Como o Decreto-lei 89.817 / ET-ADGV não define a quantidade de pontos a ser utilizada em uma avaliação da acurácia posicional, foi adotada a norma americana NSSDA (National Standard for Spatial Data Accuracy) que indica que um mínimo de 20 pontos deve ser utilizado no processo de avaliação (FGDC 1998). Alguns cuidados foram observados na escolha dos pontos e trechos de estradas, como: evitar locais com obstrução dos sinais dos satélites pela vegetação e/ou edificações; locais com acesso facilitado, por questões de logística; observância do relevo, de modo que os pontos fossem distribuídos pelas baixas, médias e altas altitudes; escolher pontos e trechos de estradas bem distribuídos espacialmente.

Foram utilizados no levantamento de campo, receptores GNSS de dupla frequência, tanto para a coleta das estradas quanto dos pontos de checagem. O processamento se deu pelo método relativo estático para os pontos e relativo cinemático para as estradas. A maior linha de base 
utilizada foi da ordem de $8,5 \mathrm{~km}$. Os pontos e os trechos de rodovias coletados, após o processamento, apresentaram uma precisão posicional planimétrica entre $15 \mathrm{~cm}$ e $50 \mathrm{~cm}$, respectivamente.

Em seguida, foi realizado o processo de monorestituição das linhas correspondentes aos trechos de rodovias, e coletadas as coordenadas dos pontos homólogos na ortoimagem, sendo todos estes processos realizados no software ArcGIS. De posse da amostra de coordenadas dos pontos de checagem campo e seus homólogos na ortoimagem, bem como os trechos de estradas coletados em campo e seus homólogos na ortoimagem, foi possível aplicar os métodos propostos de avaliação da acurácia posicional planimétrica.

De posse das amostras de discrepâncias, obtidas pelos diferentes métodos de feições lineares e por pontos, foram verificadas as independências estatísticas pelo teste do Qui-Quadrado e, se comprovadas, o teste de normalidade Shapiro-Wilk. Utilizou-se o software R (R Core Team 2014) para a aplicação de tais testes estatísticos.
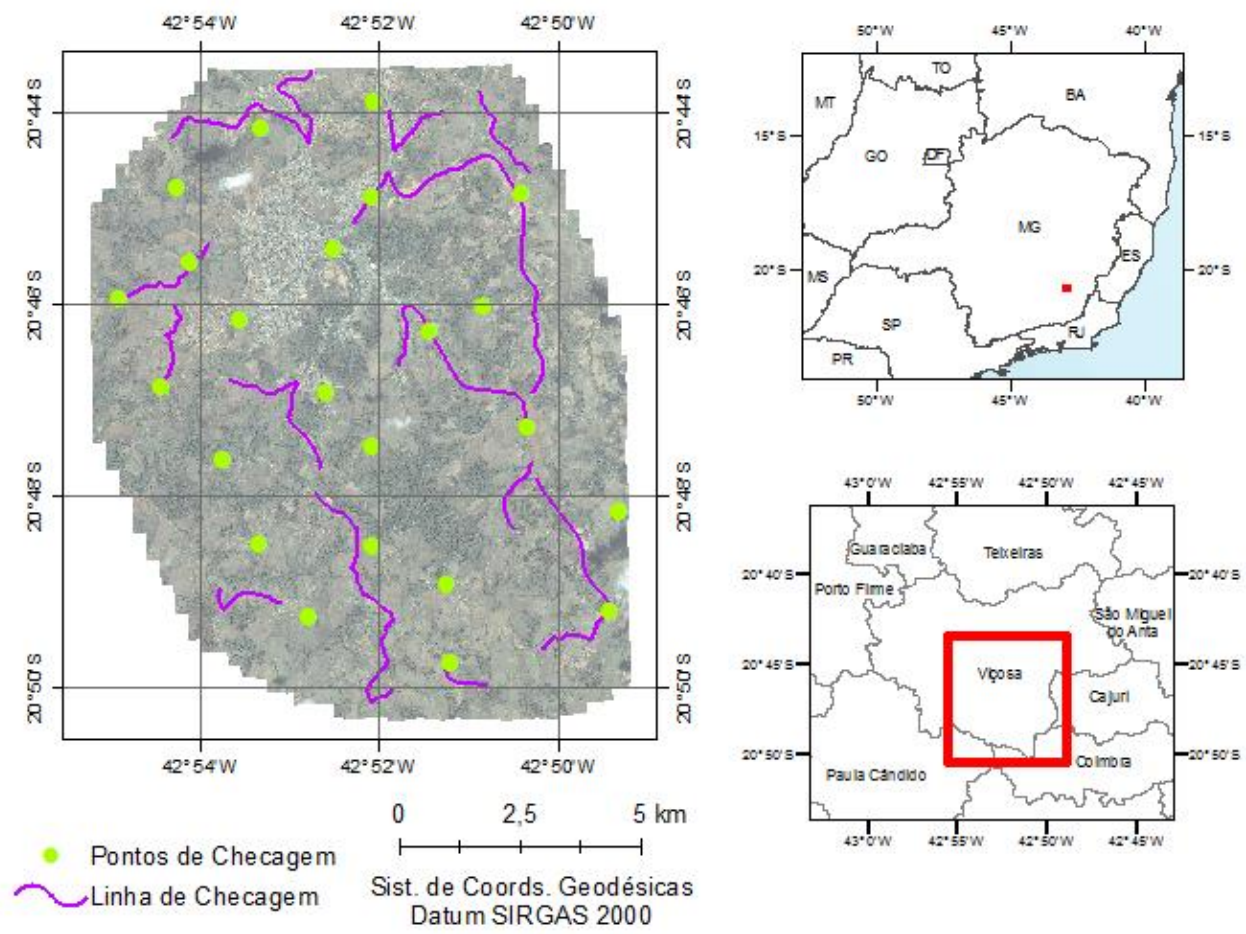

Figura 7: Pontos e linhas utilizadas no processo de avaliação da acurácia posicional da ortoimagem Ikonos.

Constatada a normalidade da amostra de discrepâncias, fez-se a avaliação da acurácia posicional da imagem Ikonos utilizando os valores de PEC e EP para a escala 1:10.000, conforme apresentado pela Tabela 2. Esta escala foi utilizada, baseando-se nos trabalhos de Machado e Silva (2007), Santos et al. (2010) e Santos et al. (2012), os quais sugerem tal escala para geração de produtos cartográficos advindo da utilização de imagens Ikonos ortorretificadas utilizando RPCs, sem pontos de controle. 
Tabela 2: Valores para PEC e EP na escala de 1:10.000

\begin{tabular}{c|c|c|c}
\hline Classe & Classe & \multicolumn{2}{|c}{ Escala 1:10.000 } \\
\cline { 3 - 4 } PEC & PEC-PCD & PEC & EP \\
\hline- & $\mathrm{A}$ & $2,8 \mathrm{~m}$ & $1,7 \mathrm{~m}$ \\
\hline $\mathrm{A}$ & $\mathrm{B}$ & $5 \mathrm{~m}$ & $3 \mathrm{~m}$ \\
\hline $\mathrm{B}$ & $\mathrm{C}$ & $8 \mathrm{~m}$ & $5 \mathrm{~m}$ \\
\hline $\mathrm{C}$ & $\mathrm{D}$ & $10 \mathrm{~m}$ & $6 \mathrm{~m}$ \\
\hline
\end{tabular}

Como resultados da aplicação dos métodos de feições lineares, têm-se a Figura 8 apresentando as discrepâncias observadas pelos métodos: (a) tradicional por pontos; (b) método das Áreas; (c) Buffe Simples - utilizando uma tolerância referente à classe B; d) método do Buffer Duplo - utilizando uma tolerância referente à classe B; (e) Distância de Hausdorff e; (f) Influência do Vértice.

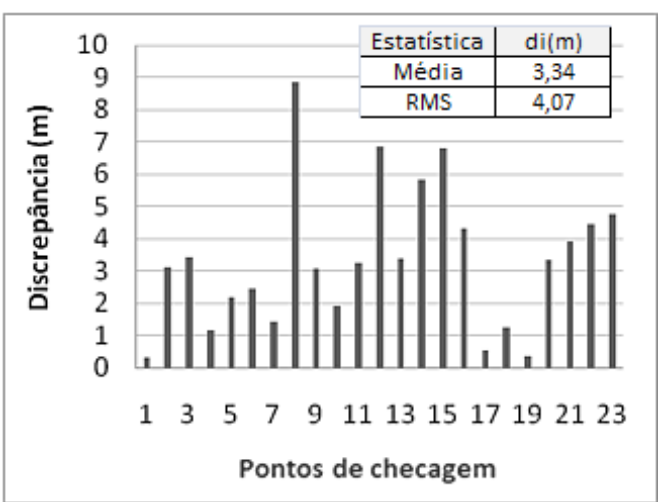

(a) Método por Pontos

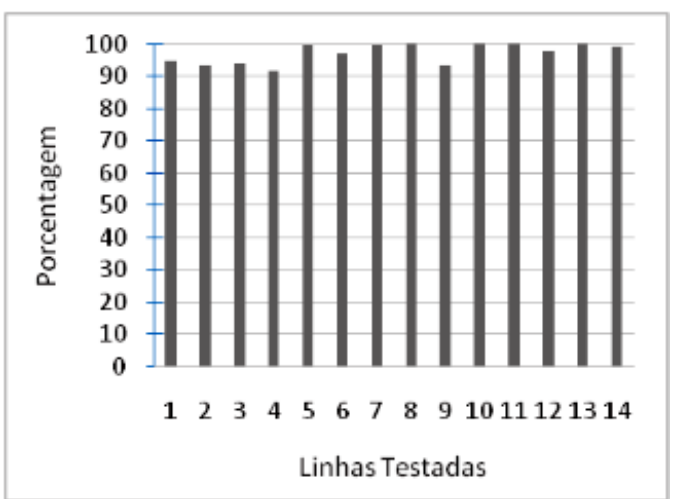

(c) Método Buffer Simples

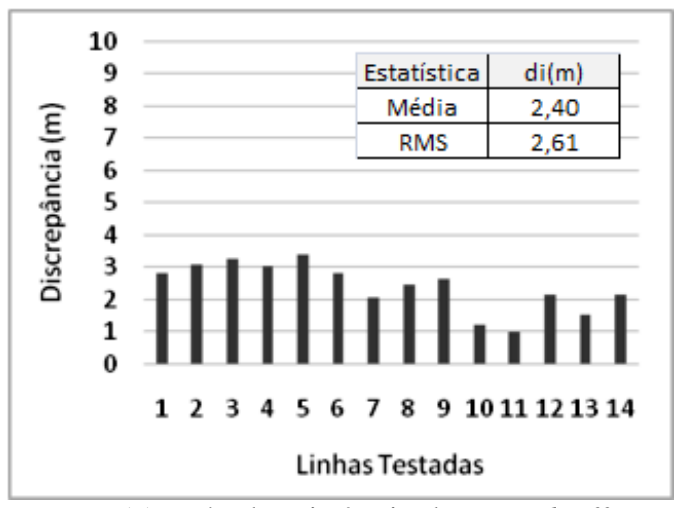

(e) Método Distância de Hausdorff

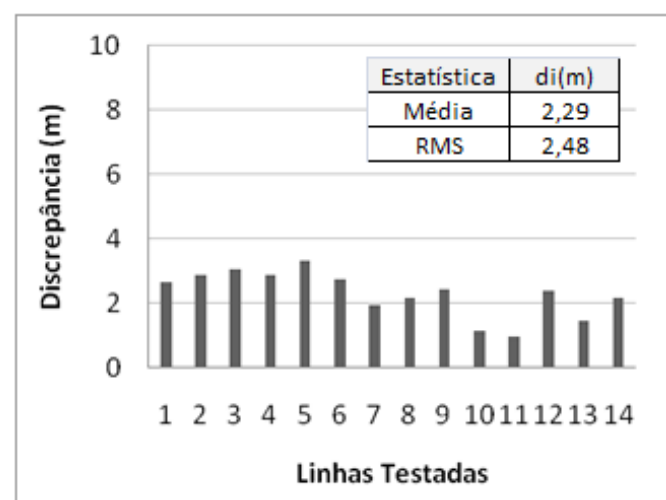

(b) Método das Áreas ( $\varepsilon$-band)

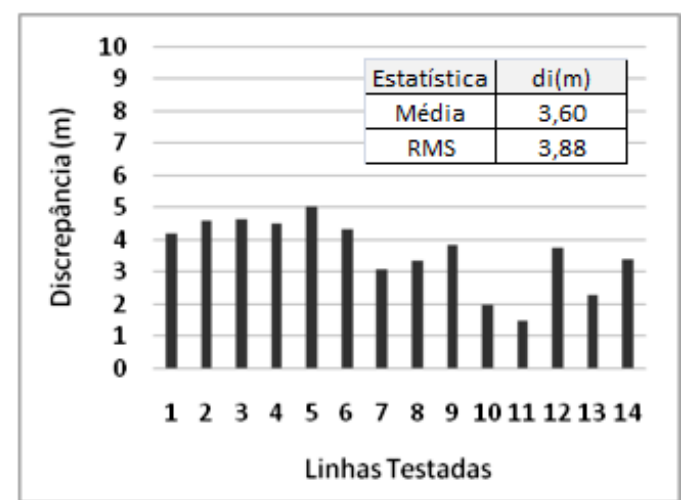

(d) Método Buffer Duplo

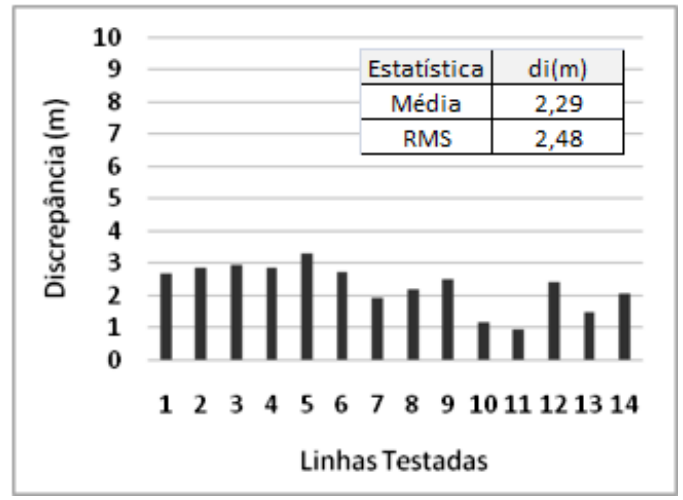

(f) Método Influência do Vértice

Figura 8: Gráfico das discrepâncias observadas utilizando o método tradicional por pontos e os métodos de feições lineares. 
Em todos os métodos utilizados para avaliação da qualidade posicional, com o uso de feições pontuais e lineares, as amostras de discrepâncias apresentaram o valor de probabilidade do QuiQuadrado significativo a 10\%, demonstrando a independência estatística destas amostras. Assim, aplicou-se o teste de normalidade Shapiro-Wilk, que apresentou valor de probabilidade significativo a $5 \%$ para todas as amostras analisadas.

A Tabela 3 apresenta os resultados obtidos a partir da aplicação do método de avaliação de feições pontuais e lineares, junto ao padrão de acurácia posicional brasileiro, descrito no Decreto-lei n ${ }^{\circ}$ 89.817, aliada à ET-ADGV.

Percebe-se que os métodos de feições lineares da Área (Banda Épsilon), Distância de Hausdorff e Influência do Vértice apresentaram resultados similares. Enquadraram-se na Classe B para escala de 1:10.000, com média e RMS das discrepâncias em torno de 2,3 a 2,5 metros, respectivamente.

Tabela 3: Classificação da acurácia posicional da imagem Ikonos, utilizando como padrão o Decreto-lei n 89.817 / ET-ADGVpara a escala 1:10.000.

\begin{tabular}{c|c|c|c|c|c|c}
\hline Método & Pontos & Met. Área & B. Simples & B. Duplo & D. Hausd. & Inf. Vert. \\
\hline $\begin{array}{c}\text { Classe } \\
\text { PEC-PCD }\end{array}$ & C & B & C & C & B & B \\
\hline
\end{tabular}

Os métodos do Buffer Duplo e Buffer Simples se mostraram mais rigorosos quando comparado aos demais métodos de feições lineares testados. Ao testar estes dois métodos, utilizando como tamanho do buffer a tolerância do PEC-PCD para a Classe A e B da escala 1:10.000, os mesmos não obtiveram classificação quanto ao Decreto-lei 89.817 / ET-ADGV. Assim, gerou-se outras duas amostras de discrepâncias, para o método do Buffer Simples e Buffer Duplo, a partir da definição do tamanho do buffer como sendo a tolerância do PEC-PCD para a Classe C da escala 1:10.000. Ao avaliar a acurácia posicional destas novas amostras de discrepâncias, ambos os métodos enquadraram-se na Classe C para a escala 1:10.000. O Buffer Duplo apresentou média e RMS das discrepâncias em torno de 3,6 e 3,9 metros.

$\mathrm{O}$ método tradicional que utiliza pontos foi classificado como Classe $\mathrm{C}$, apresentando discrepâncias médias de 3,3 metros e RMS em torno de 4 metros. As maiores discrepâncias foram verificadas nos pontos 8, 12, 14 e 15, variando de 5,8 a 8,8 metros. Apesar destes pontos apresentarem altos valores de discrepâncias, quando comparados aos outros pontos de checagem, os mesmo não se caracterizam como outliers. Santos (2010), baseado em Nero (2005), sugere utilizar o limite de $3 * \mathrm{EP}$, para a classe A do Decreto-lei 89.817 (Classe B do PEC-PCD) da escala testada, para detectar erros grosseiros.

Os métodos de feições lineares apresentaram valores de discrepância mais homogêneos, quando comparados ao método tradicional por pontos, da ordem de 2 a 4 metros.

Pode-se perceber, que ao analisar a média e o RMS das discrepâncias entre os métodos aplicados, o método de feição pontual se mostrou similar ao método de feição linear do Buffer Duplo, apresentando valores da ordem de 3,5 e 4 metros, respectivamente.

Assim, pode-se considerar, diante dos resultados dos métodos utilizados neste trabalho, que o método por pontos, o Buffer Duplo e o Buffer Simples são mais rigorosos que os demais para detecção de discrepâncias posicionais no produto avaliado. Desta forma, o método tradicional por pontos, onde a discrepância é obtida pela resultante posicional entre as coordenadas do ponto teste e as coordenadas do ponto de referência se mostrou uma das formas mais fidedignas de se verificar as discrepâncias de um produto cartográfico. Os métodos de feições lineares, em sua grande maioria, obtêm um valor de discrepância média baseado nas diferenças entre as linhas homólogas ou entre os vértices das mesmas. Desta forma, pode-se ter uma linha que apresente uma discrepância média de valor razoável, mas que em algum trecho desta, apresente uma diferença significativa. No método tradicional por pontos se existir algum ponto de 
checagem com valor alto de discrepância, este valor poderá influenciar as estatísticas da amostra de checagem, mostrando que o produto tem alguma inconsistência. Já em alguns métodos de feições lineares (como a Distância de Hausdorff e Influência do Vértice), a ocorrência de uma diferença significativa em um trecho de alguma linha é minimizada devido ao cálculo da discrepância média considerar toda a linha ou todos os vértices da linha. A aplicação dos métodos de feições lineares, de um modo geral, pode ser eficiente quando: (i) os pontos de checagem não possuem uma boa distribuição espacial na região de estudo e; (ii) quando se utiliza de um processo automatizado, onde a identificação e extração de feições lineares são mais fáceis de serem implementadas em relação às feições pontuais.

\section{CONCLUSÃO}

Este trabalho buscou apresentar o potencial e a viabilidade de utilização de métodos de avaliação da acurácia posicional em dados espaciais que utilizam feições lineares tendo por base o padrão de acurácia posicional brasileiro, definido pelo Decreto-lei $n^{\circ}$ 89.817. Os métodos utilizados são relativamente de simples implementação, em um ambiente de Sistema de Informações Geográficas, sendo mais uma alternativa para o Controle de Qualidade de bases cartográficas.

De um modo geral, os resultados da avaliação da ortoimagem Ikonos apresentaram classificações, quanto ao Decreto-lei ${ }^{\circ} 89.817$ / ET-ADGV, similares na aplicação dos métodos da Banda Épsilon, Distância de Hausdorff, Influência do Vértice. Para a ortoimagem Ikonos, o uso destes métodos apresentou classificação B para a escala de 1:10.000.

Já os métodos de feição linear Buffer Simples e Buffer Duplo mostraram classificação similar ao método tradicional por pontos na avaliação da ortoimagem, obtendo classificação planimétrica Classe C para a escala de 1:10.000.

Assim, recomenda-se a utilização do método Buffer Duplo ao se fazer o uso de feições lineares para realizar o controle de qualidade em dados espaciais, já que os resultados foram similares ao método tradicional por pontos, tanto na classificação da acurácia posicional quanto nas estatísticas descritivas das discrepâncias resultantes de cada método.

Apesar do método do Buffer Simples ter apresentado resultado similar ao Buffer Duplo, este último pode ser considerado mais robusto devido ao fato de gerar uma medida de discrepância, na qual pode-se investigar a presença de outliers e tendências nos dados.

Como dificuldade encontrada neste trabalho, pode-se citar a coleta em campo de trechos de estradas via receptores GNSS, já que grande parte destas consistia de estradas vicinais, na qual apresentavam, em vários locais, vegetações que obstruíam o sinal GNSS, e consequentemente, a perda do mapeamento deste trecho de estrada.

Recomenda-se, para trabalhos futuros, a investigação da integração dos padrões de acurácia posicional do Decreto-lei n ${ }^{\circ} 89.817$ / ET-ADGV aos métodos de feições lineares que se encaixam no grupo de faixa de incerteza, que utilizam uma abordagem estocástica (Banda Genérica e o Modelo de Erros Estatístico por Simulação).

\section{REFERÊNCIAS BIBLIOGRÁFICAS}

Abbas, I. 1994. "Base de Données Vectorielles et Erreur Cartographique. Problèmes Posés Par Le Controle Ponctuel. Une Méthode Alternative Fondée Sur La Distance de Hausdorff: Le Controle Linéaire.” Paris, France: Université Denis-Diderot. 
Ariza, Francisco Javier López. 2002. “Calidad En La Producción Cartográfica.” Ra-Ma.

Ariza, Francisco Javier López, and Antonio T. Calvache Mozas. 2005. "Methodology for the Development of a Sampling Recommendation When Using Linear Elements for Positional Quality Control.” In International Cartographic Conference. La Coruña, Spain.

_. 2011. "Comparison of Four Line-Based Positional Assessment Methods by Means of Synthetic Data.” GeoInformatica 16 (2): 221-43. doi:10.1007/s10707-011-0130-y.

Atkinson, Alan D. J., and Francisco Javier López Ariza. 2002. "Nuevo Enfoque Para El Análisis de La Calidad Posicional En Cartografia Mediante Estudios Basados En La Geometría Lineal." In XIV Congreso Internacional de Ingeniería Gráfica. Santander, Spain.

Blakemore, M. 1984. "Generalization and Error in Spatial Databases.” Cartographica 21: 13139.

BRASIL. 1984. Decreto $N^{\circ} 89.817$ de 20 de Junho de 1984. Normas Técnicas Da Cartografia Nacional. Brazil. http://www.planalto.gov.br/ccivil_03/decreto/1980-1989/D89817.htm.

DSG. 2011. Especificação Técnica Para a Aquisição de Dados Geoespaciais Vetoriais (ET$A D G V)$. Brasil. http://www.geoportal.eb.mil.br/images/PDF/ET_ADGV_Vs_2_1_3.pdf.

FGDC. 1998. Geospatial Positioning Accuracy Standards Part 3: National Standard for Spatial Data Accuracy. World. http://www.fgdc.gov/standards/projects/FGDC-standardsprojects/accuracy/part3/chapter3.

Galo, Maurício, and Paulo O. Camargo. 1994. "O Uso Do GPS No Controle de Qualidade de Cartas." In $1^{\circ}$ Congresso Brasileiro de Cadastro Técnico Multifinalitário. Florianópolis, Brazil.

Galo, Mauricio, Aluir Porfírio Dal Poz, and France Michel Ferreira. 2001. "O Uso De Feições No Controle De Qualidade Em Cartografia.” In XIX Congresso Brasileiro de Cartografia. Porto Alegre, Brazil.

Goodchild, Michael F. 2010. "Foreword.” In Principles of Modeling Uncertainties in Spatial Data and Spatial Analyses. CRC Press.

Goodchild, Michael F., and Gary J. Hunter. 1997. “A Simple Positional Accuracy Measure for Linear Features." International Journal of Geographical Information Science 11 (3). Taylor \& Francis: 299-306. doi:10.1080/136588197242419.

Habib, A., M. Morgan, E. M. Kim, and R. Cheng. 2004. "Linear Features in Photogrammetric Activities." In International Archives of the Photogrammetry, Remote Sensing and Spatial Information Sciences, 35:610-15. Istanbul, Turkey.

Heipke, C, H Mayer, C Wiedemann, Remote Sensing, and O Jamet. 1997. "Evaluation of Automatic Road Extraction." International Archives of Photogrammetry and Remote Sensing, 47-56. doi:10.1.1.30.7686.

Lugnani, João Bosco. 1986. "Estimativa de Qualidade de Feições Digitalizadas - Um Novo Método." Revista Brasileira de Cartografia 39.

Lunardi, Omar Antônio, Alex De Lima Teodoro Da Penha, and Rodrigo Wanderley De Cerqueira. 2012. "O Exército Brasileiro E Os Padrões De Dados Geoespaciais Para a Inde." In IV Simpósio Brasileiro de Ciências Geodésicas E Tecnologias Da Geoinformação Recife, 1-8. Recife, Brazil.

Machado e Silva, Antonio. J. F. 2007. “O Uso de Polinômios Racionais Na Ortorretificação de Imagens de Satélite.” In XIII Simpósio Brasileiro de Sensoriamento Remoto. Florianópolis, Brazil. 
Masry, S. E., J. R. R. Gauthier, and Y. C. Lee. 1980. "Accuracy and Time Comparisons of Digital Maps.” In International Society of Photogrammetry. Hamburg.

Mood, Alexander MacFarlane, Franklin A. Graybill, and Duane C. Boes. 1974. Introduction to the Theory of Statistics. McGraw-Hill International.

Mozas, Antonio T, and Francisco J Ariza. 2010. "Methodology for Positional Quality Control in Cartography Using Linear Features." Cartographic Journal. doi:10.1179/000870410X12825500202931.

Mozas, Antonio T., and Francisco J. Ariza. 2011. "New Method for Positional Quality Control in Cartography Based on Lines. A Comparative Study of Methodologies." International Journal of Geographical Information Science 25 (10). Taylor \& Francis: 1681-95. doi:10.1080/13658816.2010.545063.

Mozas, Antonio T. Calvache. 2007. "Control de La Calidad Posicional En Cartografia Por Elementos Lineales.” Jaén: Universidad de Jaén, Spain.

Nero, Marcelo Antônio. 2005. "Propostas Para O Controle de Qualidade de Bases Cartográficas Com Ênfase Na Componente Posicional.” São Paulo, Brazil: Escola Politécnica da USP, Brazil.

Nogueira Júnior, João Bosco. 2003. “Controle de Qualidade de Produtos Cartográficos: Uma Proposta Metodológica.” Presidente Prudente, Brazil: Faculdade de Ciências e Tecnologia UNESP, Brazil.

Pereira, T. A. J., and M. A Nero. 2012. "Análises de Normas de Controle de Qualidade Cartográfica Ao Redor Do Mundo: Exemplos Atuais de Alguns Países." In IV Simpósio Brasileiro de Ciências Geodésicas E Tecnologias Da Geoinformação. Recife, Brazil.

Perkal, Julian. 1966. "On the Length of Empirical Curves." Michigan Inter-University Community of Mathematical Geographers 10: 17-20.

R Core Team. 2014. "R: A Language and Environment for Statistical Computing." $R$ Foundation for Statistical Computing.

Santos, Afonso Paula. 2010. “Avaliação Da Acurácia Posicional Em Dados Espaciais Com O Uso de Estatística Espacial.” Viçosa, Brazil: Universidade Federal de Viçosa.

Santos, Afonso Paula, Ítalo Oliveira Ferreira, Nilcilene Graças Medeiros, Dalto Domingos Rodrigues, and Joel Gripp Junior. 2012. "Avaliação Da Acurácia Posicional Em Imagens Ikonos Ortorretificadas Com O Uso de RPCs Aliado a Pontos de Controle." In IV Simpósio Brasileiro de Ciências Geodésicas E Tecnologias Da Geoinformação. Recife, Brazil.

Santos, Afonso Paula, Leila Freitas Oliveira, Wellington Donizete Guimarães, and Carlos Antônio Oliveira Vieira. 2010. “Avaliação Da Acurácia Planimétrica de Imagens Ikonos Ortorretificadas Com Diferentes MDEs." In XXIV Congresso Brasileiro de Cartografia. Aracaju, Brazil.

Shi, W. 2010. Principles of Modeling Uncertainties in Spatial Data and Spatial Analyses. CRC Press.

Tong, Xiaohua, Tong Sun, Junyi Fan, Michael F Goodchild, and Wenzhong Shi. 2013. “A Statistical Simulation Model for Positional Error of Line Features in Geographic Information Systems (GIS)." International Journal of Applied Earth Observation and Geoinformation 21 (0): 136-48. doi:http://dx.doi.org/10.1016/j.jag.2012.08.004.

Tveite, Havard, and S. Langaas. 1999. “An Accuracy Assessment Method for Geographical Line Data Sets Based on Buffering." International Journal of Geographical Information Science 13 (1). Taylor \& Francis Group: 27-47. doi:10.1080/136588199241445. 
Vieira, Carlos Antônio Oliveira, Paul M. Mather, and Paulo A. F. Borges. 2002. "Assessing the Positional Accuracy of Remotely Sensed Products.” In 5th International Symposium on Spatial Accuracy Assessment in Natural Resources and Environmental Sciences. Melbourne, Australia.

(Recebido em julho de 2014. Aceito em dezembro de 2014). 


\title{
SENSIBILIDADE DE ESPECTROS DE ONDAS OCEÂNICAS RECUPERADOS POR RADAR DE ABERTURA SINTÉTICA
}

\author{
Sensitivity of ocean-wave spectra retrieved by synthetic aperture radar
}

\author{
ANDRÉ LUIZ CORDEIRO DOS SANTOS 1,2 \\ FELIPE MARQUES DOS SANTOS ${ }^{2}$ \\ LUIZ MARIANO CARVALHO ${ }^{2,3}$ \\ NELSON VIOLANTE-CARVALHO \\ ${ }_{1}^{1}$ Centro Federal de Educação Tecnológica do Rio de Janeiro, Departamento de Ensino Superior \\ Avenida Maracanã 229, Maracanã, CEP 20271-110, Rio de Janeiro - Brasil \\ andreluiz.cordeiro@gmail.com \\ 2 Universidade do Estado do Rio de Janeiro, Programa de Pós Graduação em Engenharia Mecânica. \\ Rua Fonseca Teles 121, São Cristóvão, CEP 20940-903, Rio de Janeiro - Brasil \\ felipems@gmail.com \\ ${ }^{3}$ Universidade do Estado do Rio de Janeiro, Instituto de Matemática \\ Rua São Francisco Xavier, 524, 4015E, CEP 20550-900 Rio de Janeiro, RJ, Brasil \\ luizmc@gmail.com \\ ${ }^{4}$ Universidade Federal do Rio de Janeiro, Programa de Engenharia Oceânica \\ Av. Athos da Silveira Ramos, 274. Cidade Universitária, Ilha do Fundão, CEP 21941-916, Rio de \\ Janeiro, RJ, Brasil \\ violante_carvalho@yahoo.co.uk
}

\section{Resumo:}

SAR (Synthetic Aperture Radar ou Radar de Abertura Sintética) é o único sensor transportado por satélites capaz de medir o espectro direcional de ondas. Sua elevada cobertura espacial e temporal permite caracterizar o estado de mar, especialmente a região de baixa frequência do espectro de energia, que vem sendo assimilada em modelos numéricos de previsão de ondas em diversos centros operacionais espalhados pelo globo. Contudo, a extração do espectro de ondas de uma imagem SAR é um procedimento complexo. Alguns modos de operação não permitem o emprego de imagens sequenciais para resolver a ambiguidade direcional de propagação das ondas, o que requer informações adicionais, geralmente obtidas de um modelo de ondas. A dependência destas informações adicionais é investigada aplicando-se a inversão clássica de Hasselmann a alguns estados de mar teóricos. Esta abordagem é baseada na transformação 
analítica do espectro direcional de ondas sobre o espectro de imagem SAR correspondente. A solução deste problema inverso é determinada por um algoritmo numérico que minimiza um funcional não linear. Apesar de amplamente utilizado por diversos centros operacionais de previsão, este método não foi extensivamente testado em cenários experimentais bem definidos. Os resultados mostram que a dependência investigada é bastante significativa, sobretudo no que diz respeito à direção de propagação das ondas, levantando questionamentos sobre a acurácia da técnica.

Palavras-chave: Espectro de Ondas; Sensibilidade; Radar de Abertura Sintética.

\begin{abstract}
:
Synthetic Aperture Radar (SAR) is the only sensor to date on-board satellites able to measure the directional wind wave spectrum. Its high spatial and temporal coverage allows the characterization of the sea state, especially at the low frequency region of the energy spectrum, which has been assimilated into numerical models at several operational centres world wide since the late 1990's. However, the extraction of the wave spectrum from a SAR image is a complex task. Not all imaging modes allow the use of sequential images to resolve the wave directional ambiguity, requiring some sort of additional, first guess information, in general from a wave model. The dependency of the wave retrieval on this first guess is investigated applying the classical Hasselmann inversion to some simple, theoretical, sea states. This approach is based on the analytical transformation relating the wind wave variance spectrum to its correspondent SAR image spectrum. The solution of this inverse problem is determined by a numerical algorithm, which minimizes a non-linear function. Although widely employed at operational forecasting centres, the method has not been extensively tested in experimental, well defined, situations. The results show that the first guess wave direction is fundamental to the reliability of the results obtained, raising questions about the accuracy of the technique.
\end{abstract}

Keywords: Ocean Wave Spectra; Sensitivity; Synthetic Aperture Radar.

\title{
1. INTRODUÇÃO
}

Desde o advento do radar de abertura sintética (SAR, da sigla em inglês synthetic aperture radar), transportado em satélites, uma quantidade considerável de dados do espectro direcional de ondas tornou-se disponível para cientistas. Atualmente, SAR é o único instrumento transportado em satélites capaz de estimar o espectro direcional e, portanto, de fornecer uma caracterização completa do estado do mar. Com elevada resolução espacial e temporal, os espectros de ondas obtidos de imagens SAR vêm sendo operacionalmente assimilados por modelos numéricos implementados em diversos centros de previsão (Aouf et al 2006, Heiberg et al 2006, Abdalla et al 2006). A possibilidade de medição do espectro direcional por uma extensa área, de até algumas dezenas de quilômetros quadrados, possibilita também uma série de investigações sobre as transformações espaciais sofridas pelas ondas (Violante-Carvalho et al 2012, Wang et al 2012, Collard et al 2005).

Existem diversos mecanismos que influenciam a estimativa do espectro direcional de ondas através de um radar de abertura sintética. A análise e a interpretação destes mecanismos dependem fortemente da compreensão das interações entre as ondas oceânicas e as ondas eletromagnéticas emitidas pelo radar. Diversos modelos interpretativos foram propostos 
(Kasilingam; Shemdin, 1990), porém, um modelo que explique definitivamente o complicado fenômeno que caracteriza a formação de imagens SAR não é conhecido no momento. A estimativa do espectro de ondas a partir de imagens SAR representa um problema desafiador, em que a maior dificuldade provém do comportamento aleatório da superfície oceânica ao longo do tempo (Phillips, 1977). Apesar disto, a análise espectral de imagens SAR demonstra que, sob condições específicas, é possível obter o espectro direcional de ondas de grandes comprimentos.

Hasselmann e Hasselmann (1991) propuseram uma relação funcional entre o espectro de imagem SAR e o espectro de ondas da correspondente superfície oceânica. Esta relação deve ser invertida para fornecer uma estimativa do espectro de ondas da correspondente imagem SAR. Entretanto, esse mecanismo de inversão não é único devido à ambiguidade direcional de $180^{\circ}$ inerente ao espectro congelado da imagem e a perda de informação do espectro de imagem para frequências acima do cut-off azimutal do SAR (Violante-Carvalho et al, 2012). Segundo os autores, os movimentos orbitais induzidos por ondas geram distorções não lineares na intensidade da imagem. Isto acarreta perda de informação na direção azimutal (paralela ao deslocamento do satélite) a partir de uma região de altas frequências, dando origem ao chamado cut-off azimutal. Por conta destas limitações apontadas, a inversão da relação de mapeamento espectral oceano-SAR, que é implementada, será viável apenas quando houver um espectro de ondas inicial (first-guess) disponível. Isto implica que a aplicação de uma imagem SAR para esta finalidade, em geral, emprega um modelo de ondas operacional para obter um espectro de ondas inicial. Portanto, a técnica de inversão de Hasselmann recupera um espectro de ondas associado à imagem SAR observado que é dependente da escolha do espectro de ondas inicial usado como dado de entrada do mecanismo de inversão. O principal objetivo deste artigo é estudar a influência do espectro de ondas inicial sobre o referido mecanismo.

A motivação para este trabalho vem dos artigos de Corsini e Manara (1995) e Litovchenko e Ivanov (1993). Corsini fez estimativas de espectros de ondas recuperados de imagens SAR simuladas, enquanto Litovchenko analisou parâmetros de ondas obtidos por satélites que orbitam em altitudes diferentes, ambos utilizando o procedimento de inversão de Hasselmann. Neste artigo, aplica-se o procedimento de inversão a um espectro de imagem SAR simulado, obtido da parametrização de um espectro de ondas unimodal, aqui denominado espectro de ondas de referência. O papel do espectro de ondas de referência é representar um estado de mar idealizado. Este espectro de ondas será usado para comparar resultados obtidos pelo algoritmo de inversão quando rotações do espectro de ondas de referência são utilizadas como dado de entrada (espectro de ondas inicial) do mecanismo de inversão. Deste modo, é possível determinar o grau de correlação entre o espectro de ondas de referência e o espectro de ondas recuperado em função da direção associada ao período de pico, aqui sendo chamada de direção principal do espectro. A correlação fornece um indicativo sobre a distorção que é imposta ao espectro de ondas recuperado, que é dependente do espectro de ondas inicial usado como dado de entrada do mecanismo de inversão. Um espectro de ondas recuperado é considerado muito

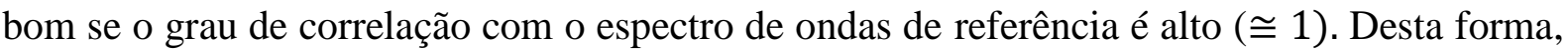
o espectro de ondas recuperado é bastante similar ao espectro de ondas de referência, que é, em teoria, a melhor resposta possível esperada do mecanismo de inversão. Paralelamente a isto, são avaliados os impactos sobre os parâmetros de ondas associados ao espectro de ondas recuperado, de modo a refinar ainda mais a análise.

É importante salientar que, para a execução desta proposta, foi necessário o desenvolvimento de uma complexa ferramenta computacional, aqui denominada de processador espectral. Este processador transforma um espectro de ondas oceânicas no correspondente espectro de imagem SAR e, portanto, constitui um ingrediente fundamental neste contexto: dispensa a necessidade de uma imagem SAR obtida de um satélite ou de um simulador de imagens. Acoplado ao processador espectral, é utilizado o algoritmo responsável pela inversão, doravante chamado simplesmente de algoritmo MPI (Max Plank Institute), desenvolvido na instituição que lhe dá 
o nome (Hassemann; Hasselmann, 1991). Há outras rotinas menores, porém importantes, envolvidas neste procedimento as quais serão destacadas oportunamente ao longo do texto.

Não são conhecidos trabalhos publicados em periódicos cuja abordagem aqui proposta tenha sido utilizada para medir a distorção do espectro de ondas recuperado pelo mecanismo de inversão de Hasselmann. Nota-se que devido à complexidade do processo de formação de imagem SAR, simulações numéricas constituem uma importante ferramenta para uma melhor compreensão do processo de recuperação de espectro de ondas através de radares de abertura sintética.

Por fim, apresenta-se a estrutura do artigo: na seção 2, o SAR e seus mecanismos fundamentais são brevemente discutidos. Na seção 3, o algoritmo de inversão e o modelo teórico utilizado são descritos. Também são apresentados os conceitos de correlação espectral e de desvios (dos parâmetros de ondas), além do esquema numérico correspondente ao modelo teórico. $\mathrm{O}$ algoritmo utilizado para a realização das simulações é descrito na seção 4 . Na seção 5, apresentam-se as conclusões.

A discussão apresentada na sequência tem como principal objetivo explicar a razão da simulação de ondas se propagando em três direções distintas em relação ao deslocamento do satélite: ondas se propagando na direção de range (ortogonal em relação ao deslocamento do satélite), na direção azimutal (paralela ao deslocamento do satélite) e numa direção intermediária às anteriores ( $45^{\circ}$ em relação ao deslocamento do satélite). Isto isolará a dependência das três modulações fundamentais introduzidas a seguir.

\section{SAR: MECANISMOS FUNDAMENTAIS}

Os conceitos apresentados ao longo desta seção podem ser encontrados em, por exemplo, Robinson (2004). No oceano são observadas ondas com uma grande variedade de comprimentos. De ondas centimétricas, geradas quando o vento começa a enrugar uma superfície espelhada, até ondas de algumas centenas de metros, típicas de ondulações. O pulso eletromagnético emitido pelo radar SAR, apresentando comprimento de onda de alguns centímetros, interage com as ondas presentes na superfície do oceano com comprimentos de mesma ordem, em um mecanismo denominado ressonância de Bragg. De forma geral, o sinal eletromagnético retroespalhado é proporcional à amplitude destas ondas centimétricas, denominadas ondas de Bragg, sempre presentes na superfície do oceano caso haja ventos de intensidade mínima de $3 \mathrm{~m} / \mathrm{s}$ aproximadamente.

As ondas de Bragg são as ondas efetivamente medidas pelo radar, porém apresentam menor importância do ponto de vista prático quando comparadas às ondas de maior comprimento e com maior energia. Estas ondas de maior comprimento se tornam detectáveis pelo radar uma vez que modulam as ondas de Bragg em um mecanismo chamado de duas escalas (two-scale model). Basicamente são três os mecanismos de modulação das ondas de Bragg que tornam as ondas de maior comprimento observáveis pelo SAR:

(m1) modulação de inclinação - altera o ângulo de incidência da energia emitida pelo satélite em função da esbeltez das ondas de maior comprimento.

(m2) modulação hidrodinâmica - advém das zonas de convergência e divergência de ondas de Bragg decorrentes dos movimentos orbitais induzidos por ondas de maior comprimento.

(m3) velocity bunching - efeito oriundo do mecanismo de abertura sintética empregada pela técnica SAR. Para simular uma antena de maior abertura, e consequentemente aumentar a resolução espacial, o desvio Doppler do sinal de um mesmo alvo mapeado em momentos distintos do deslocamento do satélite é empregado para determinar sua posição no plano da imagem. Como a superfície do oceano é um alvo não estático devido ao movimento orbital 
induzido pela presença das ondas de maior comprimento, este movimento induz uma alteração na frequência do sinal retroespalhado. Dependendo da esbeltez das ondas, esta alteração se torna altamente não linear impossibilitando a correção da posição do alvo no plano da imagem. A modulação de inclinação e a modulação hidrodinâmica são responsáveis pela detecção das ondas se propagando em uma direção ortogonal ao deslocamento do satélite (direção de range), enquanto que o velocity bunching é responsável pela detecção de ondas se propagando paralelamente à direção de deslocamento do satélite (direção azimutal).

\section{METODOLOGIA}

\subsection{Algoritmo de Inversão}

O estado do mar pode ser estatisticamente caracterizado pelo espectro bidimensional de ondas, o qual descreve a distribuição da energia da onda com respeito à direção de propagação e sua frequência. A primeira etapa na definição de um procedimento numérico para recuperação de espectro de ondas a partir de imagens SAR é determinar a relação entre a variância da intensidade da imagem SAR e a variância da elevação das ondas do mar. Estas variâncias estão relacionadas através da transformação H (Hasselmann; Hasselmann, 1991; Krogstad; Shyberg, 1992), de tal forma que

$$
\mathrm{H}(P(\boldsymbol{k}))=S_{\text {sar }}(\boldsymbol{k})
$$

Em (1), $P$ e $S_{\text {sar }}$ denotam, respectivamente, o espectro de ondas e o espectro de imagem SAR, sendo $\boldsymbol{k}$ o vetor número de onda. A transformação $\mathrm{H}$ é denominada transformada de Hasselmann, uma aplicação fortemente não linear que carrega todas as informações sobre a modulação SAR através das funções de transferência de modulação. A hipótese fundamental feita por Hasselmann, a qual permitiu estabelecer a relação (1), foi supor que a modulação SAR (modulação de inclinação + modulação hidrodinâmica + velocity bunching) está linearmente relacionada com a elevação do oceano através de filtros, representados por suas respectivas funções de transferência (Krogstad; Shyberg, 1992).

Basicamente, o procedimento de inversão consiste na obtenção do espectro direcional de ondas a partir uma de imagem SAR. Entretanto, esse mecanismo de inversão não é único devido à ambiguidade direcional de $180^{\circ}$ inerente ao espectro congelado da imagem e à perda de informação do espectro de imagem para frequências acima do cut-off azimutal do SAR. Estas dificuldades são contornadas através de um espectro de ondas inicial (first-guess), utilizado para decidir a questão direcional, bem como de fonte de informação para estender às altas frequências, ou seja, frequências acima do cut-off azimutal.

Em termos teóricos, este procedimento é realizado pela minimização do seguinte funcional (Hasselmann; Hasselmann, 1991):

$$
\boldsymbol{J}(P)=\int\left[S_{\text {sar }}(\boldsymbol{k})-S_{o b s}(\boldsymbol{k})\right]^{2} d \boldsymbol{k}+\mu \int \frac{\left[P(\boldsymbol{k})-P^{0}(\boldsymbol{k})\right]^{2}}{[B+P(\boldsymbol{k})]^{2}} d \boldsymbol{k}
$$

Em (2), $P^{0}$ e $S_{\text {obs }}$ representam o espectro de ondas inicial e o espectro de imagem SAR observado respectivamente. A constante $\mu$, que possui uma limitação apresentada adiante, é escolhida de acordo com a confiabilidade do espectro de imagem SAR observado relativamente 
ao espectro de ondas inicial. $B$ é uma constante positiva com valor pequeno, introduzida para prevenir que o denominador da segunda integral não se anule.

Seja $P^{r}$ o espectro de ondas que satisfaz a desigualdade

$$
\boldsymbol{J}\left(P^{r}\right) \leq \boldsymbol{J}(P)
$$

qualquer que seja o espectro de ondas $P$. De acordo com (2), o espectro de ondas $P^{r}$ é recuperado da informação fornecida pelo espectro de imagem SAR observado $S_{o b s}$ e pelo espectro inicial de ondas $P^{0}$. Por esta razão, $P^{r}$ é denominado espectro de ondas recuperado. Segundo Komen (1994), a condição de mínimo local,

$$
\frac{\partial J}{\partial P}=0
$$

satisfeita por $P^{r}$, é obtida iterativamente através do algoritmo MPI (Max Plank Institute). Este algoritmo baseia-se em aplicações alternadas da transformação não linear H no sentido oceanoSAR e, da forma simplificada (linear) de H na inversão, isto é, no sentido SAR-oceano. A convergência do esquema iterativo a um resultado satisfatório depende da semelhança entre o espectro de ondas inicial e o espectro de ondas de referência. Desta forma, o espectro de ondas inicial, utilizado para inicializar o processo iterativo, exerce um papel fundamental neste processo. Entretanto, o esquema de iterações do algoritmo MPI converge mesmo nos casos em que o espectro de ondas inicial é pouco confiável, desde que $\mu$ não seja tão pequeno, isto é, $\mu \geq$ $\mu_{0}$ em que

$$
\mu_{0}=0,1 \max S_{o b s}^{2}
$$

e a constante $B$ seja tomada como sendo 0,01 max $\mathrm{P}^{0}$ (Hasselmann; Hasselmann, 1991). Nestas condições, nem todo resultado obtido pelo mecanismo retratará com fidelidade o estado de mar considerado. Isto motiva tentar compreender em que medida um espectro de ondas inicial influencia o resultado obtido pelo algoritmo de inversão.

\subsection{Modelo Teórico}

Num cenário operacional, o SAR faz a aquisição de imagens do oceano e, após adequado processamento de dados, o espectro de imagem SAR é obtido. Este espectro de imagem, junto com a informação prévia fornecida pelo espectro de ondas inicial, constituem os dados de entrada requeridos para a execução do algoritmo MPI. Este algoritmo fornecerá como resposta o espectro direcional de ondas associado à cena observada pelo satélite (isto é, o espectro de ondas recuperado). Devido ao processador espectral desenvolvido pelo grupo, um dos avanços obtidos neste trabalho é a possibilidade de produzir artificialmente espectros de imagens SAR a partir de parâmetros de onda escolhidos previamente. Isto abre caminhos para a realização de experimentos com grande controle sobre todos os parâmetros envolvidos neste complexo mecanismo de recuperação de espectros direcionais de onda.

Neste estudo, a execução teórica do procedimento considera os três dados de entrada enumerados a seguir:

(i1) o espectro direcional de ondas de referência: $P$

(i2) o espectro direcional de ondas inicial: $P^{0}$

(i3) o espectro de imagem observado: $\widetilde{S_{\text {obs }}}$

O espectro de ondas de referência $P$, gerado sinteticamente, caracteriza um estado de mar idealizado. Seria este o estado de mar, em teoria, observado pelo satélite. É a partir deste espectro de ondas de referência que se obtém $\widetilde{S_{o b s}}$, o espectro de imagem SAR observado. O 
espectro de ondas inicial $P^{0}$ também será obtido do espectro de ondas de referência $P$, conforme descrição feita adiante.

Inicialmente, define-se o dado de entrada (i1). Para isto, combina-se um espectro de energia do tipo JONSWAP (Hasselmann, 1973) com uma distribuição direcional do tipo $\cos ^{2 s}$ (LonguetHiggins, 1957). Computacionalmente, isto é feito utilizando-se o pacote de rotinas WAFO (sigla do inglês: Wave Analysis for Fatigue and Oceanography. WAFO-group, 2000), desenvolvido para análise e simulação de dados de onda. Essas rotinas requerem três parâmetros de onda como entrada: altura significativa $\left(H_{m_{0}}\right)$, período de pico $\left(T_{p}\right)$, direção principal $\left(\theta_{w}\right)$, além da escolha do tipo de distribuição direcional.

Em seguida, o dado de entrada (i2) pode ser definido através do espectro de ondas de referência $P$, obtido em (i1), bastando para isto efetuar adequadas perturbações dos parâmetros de ondas exigidos pelo pacote WAFO e usando-se a mesma distribuição direcional de $P$.

Finalmente, define-se o dado de entrada (i3). Em tese, esta informação é obtida através de uma aplicação direta da transformação de Hasselmann sobre (i1), o espectro de ondas de referência, isto é, $\mathrm{H}(P(\boldsymbol{k}))=S_{\text {obs }}$. A obtenção do espectro de imagem SAR observado utiliza o processador espectral, citado anteriormente. Este processador é a versão computacional da transformada de Hasselmann. Esta complexa ferramenta foi implementada em Matlab e desempenha papel destacado neste estudo, pois é responsável por gerar um espectro de imagem SAR sintético a partir de um estado de mar plenamente conhecido, dispensando o uso de uma imagem SAR para realização de experimentos.

É fundamental observar que, de acordo com o procedimento descrito, os dados de entrada (i2) e (i3) são obtidos de forma que as condições de similaridade entre os espectros referência e inicial possam ser controladas, assim como a confiabilidade do espectro de imagem SAR relativamente ao espectro de ondas inicial. De acordo com Robinson (2004), num processo operacional de aquisição de dados pelo SAR, o sinal que retorna ao radar é contaminado por ruído (speckle). O algoritmo MPI foi, por isso, concebido para receber um espectro de imagem SAR ruidoso, de modo que deve-se levar este fato em consideração. Desta forma, o espectro de imagem SAR observado, produzido sinteticamente, será dado por

$$
\widetilde{S_{\text {obs }}}(\boldsymbol{k})=\mathrm{H}(P(\boldsymbol{k}))+N(\boldsymbol{k})
$$

em que $N$ simula o efeito de speckle. Maiores detalhes sobre a introdução deste ruído gerado randomicamente serão apresentados mais adiante.

\subsection{Conceituação}

É importante definir quantidades que permitam medir a influência do espectro de ondas inicial - usado como dado de entrada pelo algoritmo MPI - sobre o espectro direcional recuperado. Neste sentido, considera-se o espectro de ondas de referência $P$ associado a um estado de mar idealizado, o espectro de imagem SAR observado $\widetilde{S_{\text {obs }}}$ correspondente à cena descrita por $P \mathrm{e}$ um espectro de ondas inicial $P^{0}$, todos obtidos conforme (i1), (i2) e (i3). A partir de agora, supõe-se, sem menção explícita, que $P^{r}$ é o espectro de ondas recuperado pelo algoritmo MPI quando utilizados o espectro de imagem $\widetilde{S_{o b s}}$ e o espectro de ondas inicial $P^{0}$ como dados de entrada.

\subsubsection{Correlação Espectral}


Um conceito importante e amplamente utilizado na comparação de imagens é o conceito de correlação. Intuitivamente, duas imagens são correlacionadas se elas são semelhantes entre si, e não são correlacionadas se elas são bastante diferentes. Por exemplo, duas cópias idênticas da mesma imagem são totalmente correlacionadas, mas adicionando-se gradualmente um ruído aleatório a uma delas, a correlação irá reduzir, até que, finalmente, tornem-se não correlacionadas. Assim, o grau de correlação fornece uma indicação para a semelhança entre as imagens.

Esta ideia pode ser adaptada ao presente contexto, usando-a para medir o grau de similaridade (correlação) entre o espectro de ondas referência e o espectro de ondas recuperado pelo SAR. Baseados em Cartwright (1990), define-se o grau de similaridade - devido ao espectro de ondas inicial $P^{0}$ - entre o espectro de ondas de referência $P$ e o espectro de ondas recuperado $P^{r}$, como sendo

$$
g\left(P^{0}\right)=\frac{P}{\|P\|} \circ \frac{P^{r}}{\left\|P^{r}\right\|}
$$

Em (7), o símbolo ${ }^{\circ}$ denota o produto interno de Frobenius entre matrizes, enquanto que o símbolo \|. . denota a norma matricial induzida por este produto interno (Stewart, 2011). O grau de similaridade (coeficiente de correlação) entre o espectro de ondas de referência e o espectro de ondas recuperado será máximo quando for igual a 1 (correlação total) e mínimo se for igual 0 (não há correlação).

\subsubsection{Parâmetros Espectrais}

A fim de atingir uma compreensão maior acerca do espectro de ondas recuperado, é importante distinguir o impacto do espectro de ondas inicial sobre cada um de seus parâmetros de onda. Assim, considerando $P$, o espectro de ondas de referência, com parâmetros espectrais

$$
\left\{H_{m_{0}}, T_{p}, \theta_{w}, \theta_{m}\right\}
$$

altura significativa, período de pico, direção principal e direção média respectivamente, e $P^{r}$, o espectro de ondas recuperado, com parâmetros espectrais (ordenados como acima)

$$
\left\{H_{m_{0}}^{r}, T_{p}^{r}, \theta_{w}^{r}, \theta_{m}^{r}\right\}
$$

definem-se os desvios associados aos parâmetros espectrais do seguinte modo:

(I) Desvio da altura significativa:

$$
D_{H}\left(P^{0}\right)=\frac{\left|H_{m_{0}}-H_{m_{0}}^{r}\right|}{H_{m_{0}}}
$$

(II) Desvio do período de pico:

$$
D_{T}\left(P^{0}\right)=\frac{\left|T_{p}-T_{p}^{r}\right|}{T_{p}}
$$

(III) Desvio da direção principal: 


$$
D_{\theta_{w}}\left(P^{0}\right)=\min \{\lambda, 2-\lambda\}
$$

em que $\lambda=\frac{\left|\theta_{w}-\theta_{w}^{r}\right|}{180}$

(IV) Desvio da direção média:

$$
D_{\theta_{m}}\left(P^{0}\right)=\min \{\beta, 2-\beta\}
$$

em que $\beta=\frac{\left|\theta_{m}-\theta_{m}^{r}\right|}{180}$.

As definições (formais) dos parâmetros espectrais podem ser encontradas em Kahma (2005). A densidade de energia espectral, que é proporcional ao quadrado da altura significativa, também será considerada a fim de complementar as análises.

\subsubsection{Esquema Numérico}

A meta fundamental é estudar o espectro direcional de ondas recuperado de um espectro de imagem SAR (observado) quando utilizados espectros de ondas iniciais obtidos de rotações do espectro de ondas de referência, como dados de entrada do algoritmo MPI (de fato, uma mudança da direção principal do espectro de ondas de referência corresponde a uma rotação do mesmo). Neste sentido, considere o espectro de ondas de referência $P$ caracterizado pelos parâmetros em $(9)$, e seja $\widetilde{S_{\text {obs }}}(\boldsymbol{k})$, o espectro de imagem SAR (observado) associado à cena teórica descrita por $P$.

A sequência

$$
\left\{P_{j}^{0}:-12 \leq j \leq 12\right\}
$$

de espectros direcionais, cujos parâmetros: altura significativa, período de pico e direção principal indicados, respectivamente, por

$$
\left\{H_{m_{0}}^{0, j}, T_{p}^{0, j}, \theta_{w}^{0, j}\right\}
$$

são numericamente definidos pelas equações,

$$
\left\{\begin{array}{l}
H_{m_{0}}^{0, j}=H_{m_{0}} \\
T_{p}^{0, j}=T_{p} \\
\theta_{w}^{0, j}=\theta_{w}+15 j
\end{array}\right.
$$

é formada apenas de rotações do espectro de ondas de referência. É importante destacar que para valores de $j$ para os quais $\theta_{w}^{0, j}$ é negativo, deve-se considerar a menor determinação positiva deste ângulo, isto é, $\theta_{w}^{0, j}+360^{\circ}$. Em particular, $P_{0}^{0}$ é o próprio espectro de ondas de referência $P$.

Assim, após todas as rotações $P_{j}^{0}$ do espectro de ondas de referência $P$ serem utilizadas como dados de entrada do algoritmo de inversão, o mecanismo terá produzido uma sequência de espectros direcionais recuperados $\left\{P_{j}^{r}\right\}$ que, juntamente com seus parâmetros, denotados por, 


$$
\left\{H_{m_{0}}^{r, j}, T_{p}^{r, j}, \theta_{w}^{r, j}, \theta_{m}^{r, j}\right\}
$$

serão avaliados através dos indicadores (correlação e desvios) estabelecidos por (11), (12), (13) e (14).

\section{SIMULAÇÕES}

A partir de um espectro de imagem SAR, define-se que um experimento consiste na obtenção do espectro de ondas recuperado (e seus parâmetros) através do processo de inversão, uma vez que uma rotação do espectro de ondas de referência tenha sido utilizada como dado de entrada para iniciar o processo. Uma simulação é um conjunto de 25 experimentos, sendo cada um deles determinado em função da rotação imposta ao espectro de ondas de referência, conforme descrito em (17). Neste trabalho foram realizadas 3 simulações, perfazendo um total de 75 experimentos. Utilizou-se uma máquina com processador Intel Core i5-3210M 2.50GHz, 4GB de memória RAM com o sistema operacional Ubuntu 12.04.5 LTS (Precise Pangolin) 64 bits na execução das rotinas. O processador espectral está implementado em Matlab, enquanto que o algoritmo MPI está implementado em Fortran.

Os parâmetros de entrada utilizados no WAFO são: $H_{m_{0}}=4,8$ metros (altura significativa), $T_{p}=13$ segundos (período de pico), $s=15$ (coeficiente no espalhamento direcional cos $2 \mathrm{~s}$ ). Para simular o efeito speckle (ruído), foi criada uma matriz com entradas aleatórias e uniformemente distribuídas variando no intervalo $[0,10]$. Esta matriz é adicionada à matriz correspondente ao espectro de imagem SAR. Os parâmetros de satélite utilizados correspondem aos do ERS-1 (European Remote Sensing), que esteve em atividade até 2011.

Uma descrição detalhada do algoritmo utilizado nas simulações realizadas é apresentada a seguir:

1. Definição dos parâmetros para geração de um espectro direcional de ondas: altura significativa, $H_{m_{0}}$, período de pico, $T_{p}$, e direção principal, $\theta_{w}$.

2. Geração de um espectro direcional de ondas utilizando rotinas do WAFO adaptadas (espectro de ondas de referência).

3. Execução do processador espectral.

3.1. Geração de um espectro da imagem SAR associado ao espectro direcional de ondas gerado no item 2, utilizando a transformação não linear de Hasselmann oceano-SAR.

3.2. Adição de ruído ao espectro da imagem SAR.

3.3. Conversão do espectro da imagem para o padrão UWA da ESA.

4. Roda 25 experimentos baseados no arquivo gerado no item 3.3.

4.1. Para $\theta_{w}=0^{\circ}$ até $345^{\circ}$ com incrementos de $15^{\circ}$. Aqui há um loop entre os passos (4.1) e (4.2) onde o valor de $\theta_{w}$ é alterado, a partir de $0^{\circ}$ até chegar em $345^{\circ}$.

4.1.1. Utiliza os mesmos valores dos parâmetros $H_{m_{0}}$ e $T_{p}$ utilizados no item 1 .

4.1.2. Geração de um espectro direcional de ondas utilizando rotinas do WAFO adaptadas (espectro de ondas inicial).

4.1.3. Roda o MPI.

4.1.4. Armazena os resultados de forma conveniente (espectro de ondas recuperado + parâmetros de onda)

4.2. Fim para.

Bol. Ciênc. Geod., sec. Artigos, Curitiba, v. 21, no 2, p.251-273, abr-jun, 2015. 


\section{RESULTADOS}

Os gráficos ao longo desta seção devem ser entendidos a partir das seguintes instruções: (I) Cada unidade no eixo horizontal corresponde à direção principal do espectro de ondas inicial utilizado como dado de entrada do algoritmo de inversão (MPI); (II) A direção principal do espectro de ondas de referência é representada em $0^{\circ}$. Os espectros de ondas de referência considerados possuem as direções: range (ortogonal em relação ao deslocamento do satélite), azimutal (paralela ao deslocamento do satélite) e intermediária às anteriores ( $45^{\circ} \mathrm{em}$ relação ao deslocamento do satélite). (III) A direção do espectro de imagem SAR está representada no eixo horizontal por $0^{\circ}$ (que coincide com a direção principal do espectro de ondas de referência) e $\pm 180^{\circ}$ (ambiguidade); (IV) A variação angular da direção principal de um espectro de ondas inicial em relação à direção principal do espectro de ondas de referência será denotada por $\Delta^{0}$. A seguir, alguns exemplos ilustrarão como determinar a direção principal de um espectro de ondas inicial. Se a direção principal do espectro de ondas de referência for, por exemplo, $15^{\circ} \mathrm{e}$ variação angular $\Delta^{0}=75^{\circ}$, então a direção principal do espectro de ondas inicial é $90^{\circ}=$ $15^{\circ}+75^{\circ}$. Se a variação for $\Delta^{0}=-120^{\circ}$, então a direção principal do espectro de ondas inicial é $15^{\circ}-120^{\circ}=-105^{\circ}$. A menor determinação positiva deste arco é $360^{\circ}-105^{\circ}=$ $255^{\circ}$;

A fim de sistematizar a análise realizada, esta tarefa será dividida em partes.

\subsection{Direção Média}

Na Figura 1, cada curva corresponde ao desvio da direção média do espectro de ondas recuperado relativamente ao espectro de ondas de referência - definido em (14) - em função da direção principal do espectro de ondas inicial. Nota-se que todas as curvas estão sobrepostas e possuem um aspecto comum: a forma de sino invertido. Isto significa que a direção média é um parâmetro do espectro de ondas recuperado que é bastante sensível à variação da direção principal do espectro de ondas inicial, e este comportamento é observado em todas as direções dos espectros de ondas de referência considerados nas simulações. De fato, o desvio da direção média aumenta à medida que a variação angular $\Delta^{0}$ também aumenta. Por exemplo, para variações angulares $\left|\Delta^{0}\right| \leq 45^{\circ}$, o desvio da direção média é menor que $20 \%$. Em particular, o desvio da direção média é máximo (igual a 100\%) quando a direção principal do espectro de ondas inicial é oposta à direção principal do espectro de ondas de referência $\left(\left|\Delta^{0}\right|=180^{\circ}\right)$. Conclui-se, portanto, que a direção média do espectro de ondas recuperado acompanha as rotações imprimidas ao espectro de ondas de referência. 


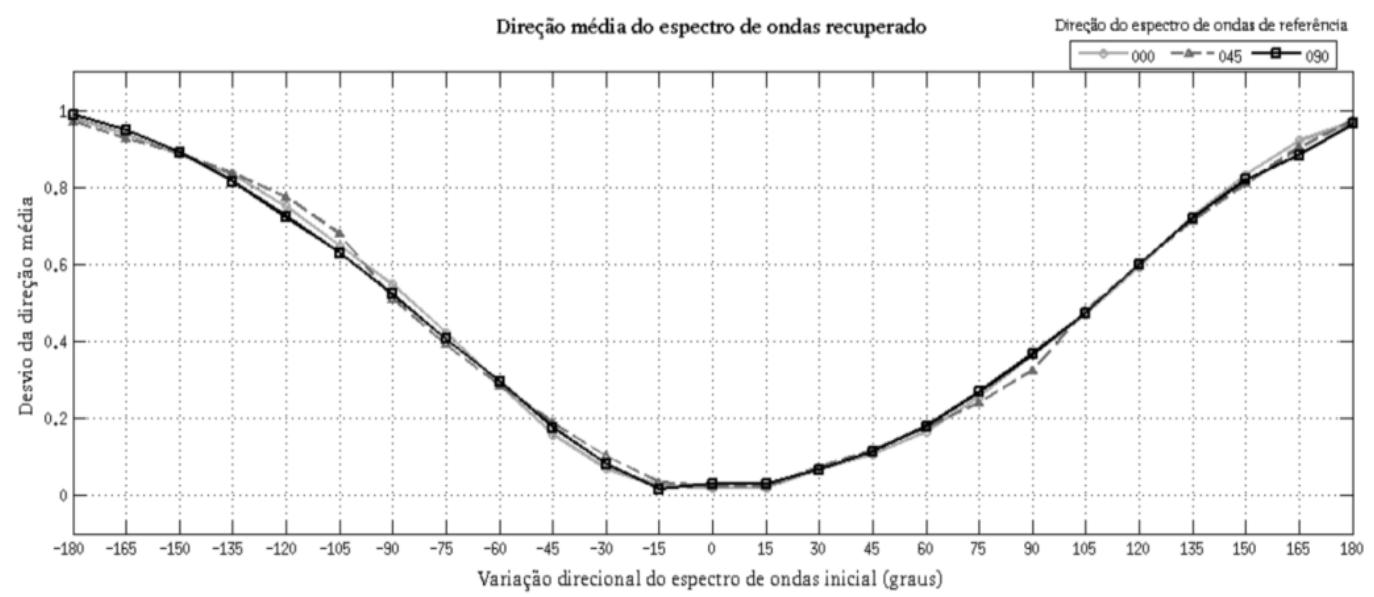

Figura 1: Representação da variação do desvio da direção média (adimensional) do espectro de ondas recuperado em função da direção principal do espectro de ondas inicial e da direção principal do espectro de referência relativamente a direção do voo do satélite.

\subsection{Direção Principal}

Na Figura 2, cada curva corresponde ao desvio da direção principal do espectro de ondas recuperado relativamente ao espectro de ondas de referência - definido em (13) - em função da direção principal do espectro de ondas inicial. Todas as curvas possuem um aspecto comum: a forma aproximada da função degrau. Isto caracteriza que a direção principal do espectro de ondas recuperado é pouco sensível às variações angulares da direção principal do espectro de ondas inicial. De fato, vê-se que se $\left|\Delta^{0}\right| \leq 60^{\circ}$, o desvio da direção principal do espectro de ondas recuperado é menor que $10 \%$. Por outro lado, para variações angulares tais que $\left|\Delta^{0}\right| \geq 75^{\circ}$, de um modo geral, o mecanismo de inversão fornece espectros recuperados com direções principais considerável ou absolutamente discrepantes da direção principal do espectro de ondas de referência. Isto é caracterizado pelo salto súbito evidenciado pelas curvas na faixa angular de $\left|\Delta^{0}\right| \cong 75^{\circ}$, pois verifica-se que a direção do espectro de ondas recuperado possui um desvio em torno $80 \%$ ou mais.

Esta discussão sugere que as repostas do algoritmo MPI, em relação à direção principal de propagação das ondas, são pouco sensíveis à direção do espectro de ondas inicial sendo determinadas principalmente pela direção do espectro de imagem SAR. De fato, considerandose que a direção do espectro de imagem observado está representada nos gráficos por $\Delta^{0}=0^{o}$ e $\Delta^{0}= \pm 180^{\circ}$, verifica-se que as curvas são estáveis nestas vizinhanças. Como contraponto, é bom lembrar que a direção média do espectro de ondas recuperado acompanha a variação da direção do espectro de ondas inicial, isto é, não há, como neste caso, estabilidade em relação às variações da direção principal do espectro de ondas inicial. 


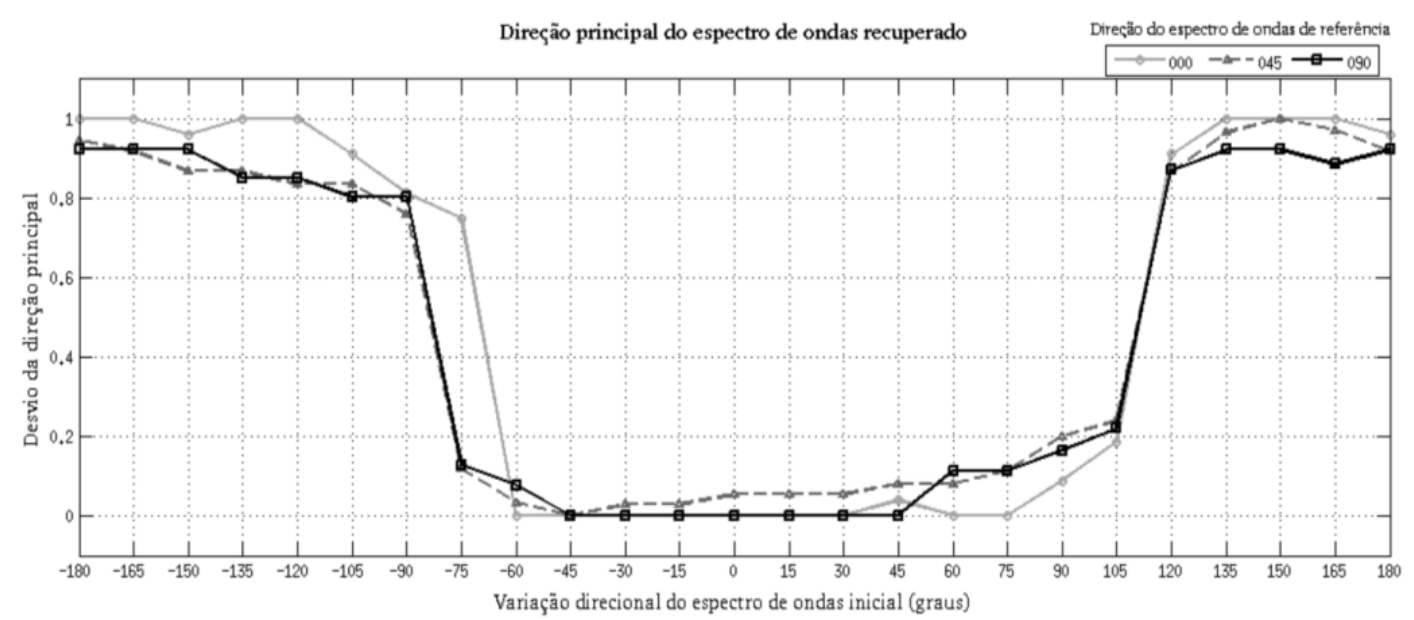

Figura 2: Representação da variação do desvio da direção principal (adimensional) do espectro de ondas recuperado em função da direção principal do espectro de ondas inicial e da direção principal do espectro de referência relativamente à direção do voo do satélite.

\subsection{Altura Significativa}

Na Figura 3-(a), cada curva corresponde ao desvio da altura significativa do espectro de ondas recuperado relativamente ao espectro de ondas de referência - definido por (11) - em função da direção principal do espectro de ondas inicial. Diferentemente do que acontece com os casos analisados anteriormente, não há, num primeiro momento, um evidente padrão comum a todas as curvas.

Analisando as curvas, observa-se que o desvio médio da altura significativa é influenciado pela direção principal do espectro de ondas de referência. Considerando a curva referente à direção azimutal $\left(0^{\circ}\right)$, o desvio médio da altura significativa é aproximadamente de $17.4 \%$. No caso da curva referente à direção intermediária $\left(45^{\circ}\right)$, verifica-se um desvio médio da altura significativa de aproximadamente $12 \%$. E, por fim, no caso da curva referente à direção de range $\left(90^{\circ}\right)$, o desvio médio da altura significativa é de aproximadamente $5 \%$. Isto revela que o desvio da altura significativa torna-se menor à medida que a direção principal das ondas se aproxima da direção de range (ortogonal ao deslocamento do satélite).

Nas Figuras 3-(b), 3-(c) e 3-(d), observa-se como varia a densidade média de energia dos espectros recuperados de acordo com a direção principal do espectro de ondas inicial, para ondas se propagando, respectivamente, nas direções azimutal, intermediária $\left(45^{\circ}\right)$ e de range. É possível notar um comportamento comum nesses gráficos: de modo geral, os maiores valores da densidade de energia são percebidos à medida que a direção principal do espectro de ondas inicial tende a alinhar-se à direção do espectro de imagem SAR. Isto ocorre quando a variação angular $\Delta^{0}$ estiver na vizinhança de $0^{\circ}$ ou $\pm 180^{\circ}$. Nota-se ainda que, nestas vizinhanças, os valores da densidade de energia aumentam quanto menor for o desvio angular entre a direção de propagação das ondas e a direção azimutal. Devido à relação entre a densidade média de energia das ondas e a altura significativa das ondas, esta análise mostra que a altura significativa é sensível à variação da direção principal do espectro de ondas inicial e tem um comportamento muito bem determinado nas condições consideradas. 

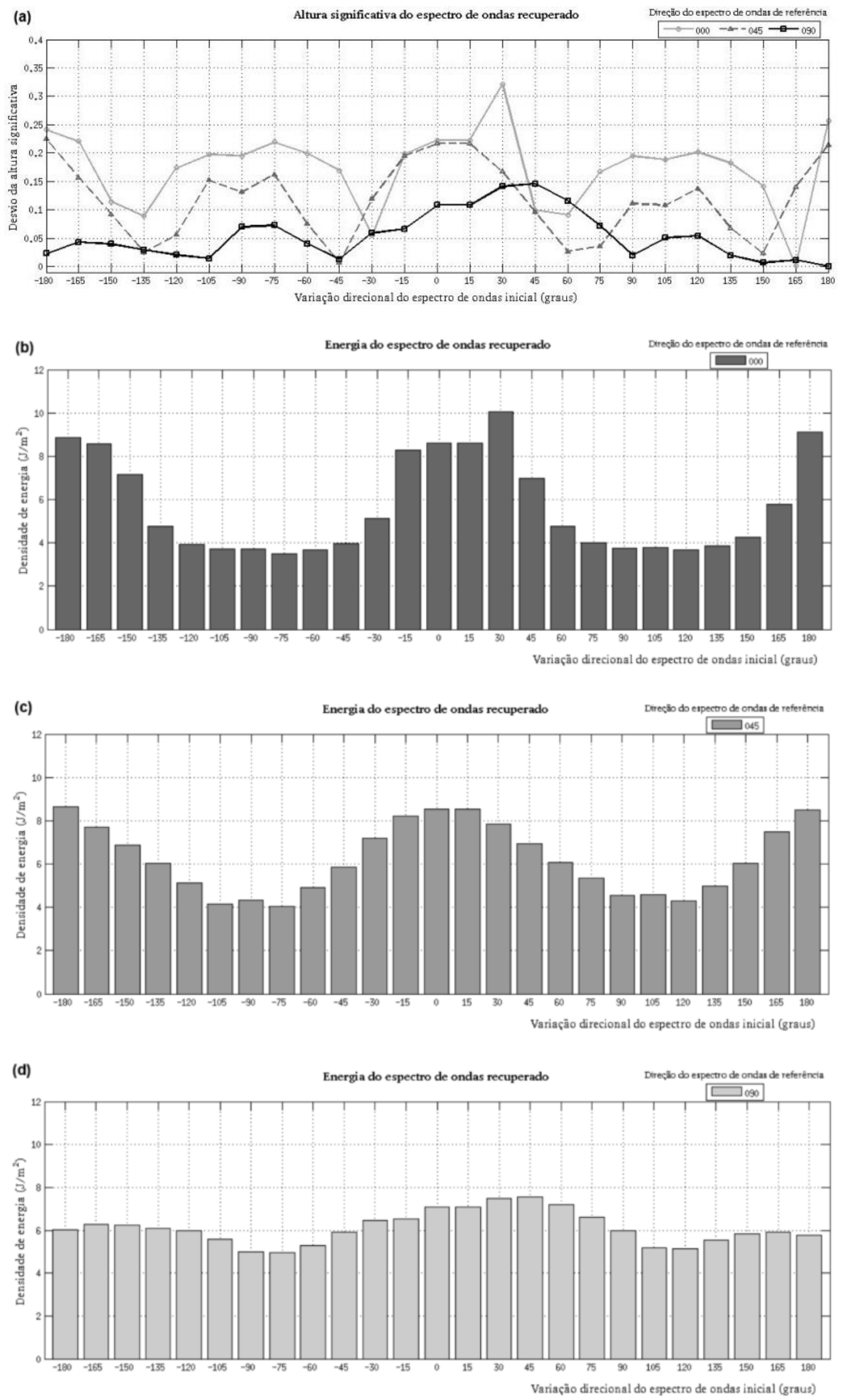

Figura 3: (a) Representação da variação do desvio da altura significativa (adimensional) do espectro de ondas recuperado em função da direção principal do espectro de ondas inicial e da 
direção principal do espectro de referência relativamente a direção do voo do satélite. Os gráficos (b), (c) e (d) representam a densidade de energia do espectro de ondas recuperado obtido de espectro de imagem SAR gerados de espectros de ondas de referência com direções principais de $0^{\circ}, 45^{\circ}$ e $90^{\circ}$.

\subsection{Período de Pico}

Na Figura 4, cada curva corresponde ao desvio do período de pico do espectro de ondas recuperado relativamente ao espectro de ondas de referência - definido por (12) - em função da direção principal do espectro de ondas inicial. As curvas estão inteiramente entrelaçadas, não configurando nenhum comportamento bem definido. Nota-se, porém, que o desvio do período de pico não é, de um modo geral, maior que $8 \%$, seja qual for a direção principal do espectro de ondas de referência considerado na simulação. Isto quer dizer que os períodos de pico dos espectros recuperados afastam-se, em média, de 1 segundo do valor do período de pico do espectro de ondas de referência. Conclui-se, portanto, que o período não é influenciado pela variação de direção principal do espectro de ondas inicial.

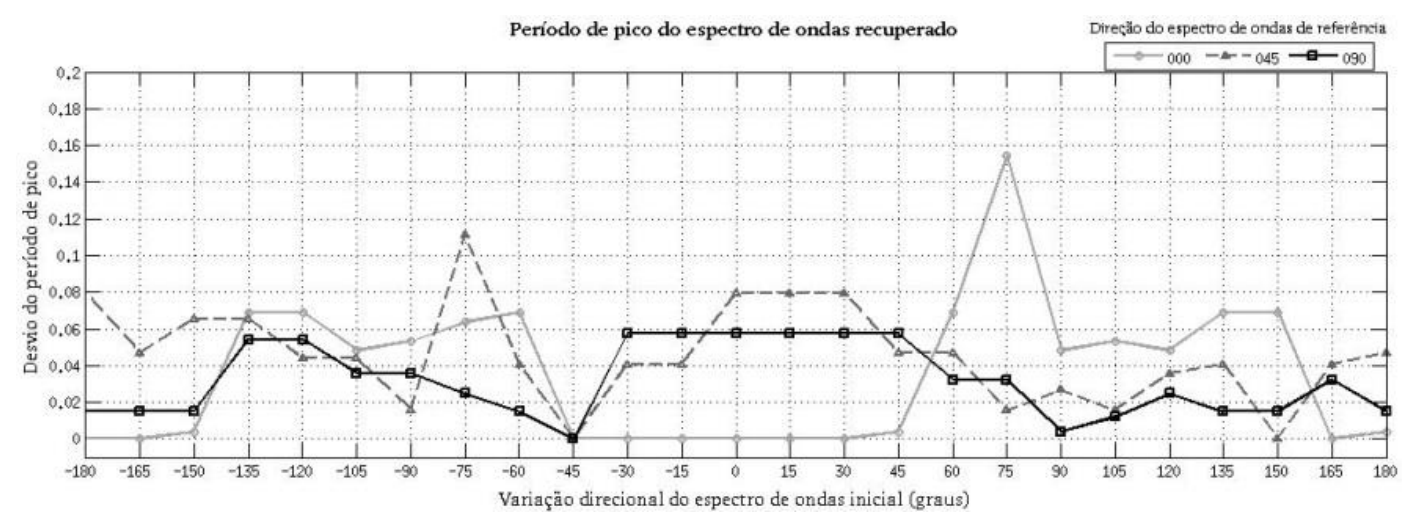

Figura 4: Representação da variação do desvio do período de pico (adimensional) do espectro de ondas recuperado em função da direção principal do espectro de ondas inicial e da direção principal do espectro de referência relativamente a direção do voo do satélite.

\subsection{Correlação Espectral}

Na Figura 5, cada curva corresponde ao coeficiente de correlação entre o espectro de ondas de referência e o espectro de ondas recuperado, definido por (7), em função da direção principal do espectro de ondas inicial. Todas as curvas possuem um aspecto comum: os maiores valores do coeficiente de correlação $(\geq 0.80)$ correspondem às menores variações angulares $\left(\left|\Delta^{0}\right| \leq 35^{\circ}\right)$. Isto quer dizer que o espectro de ondas de referência e o espectro de ondas recuperado possuem alto grau de similaridade. À medida que $\left|\Delta^{0}\right|$ aumenta, fica evidente que o grau de similaridade decresce drasticamente, acarretando que os espectros de ondas recuperados sejam muito diferentes do espectro de ondas de referência. Neste sentido, esta análise é conclusiva: o espectro de ondas recuperado depende fortemente da variação angular $\Delta^{0}$. 


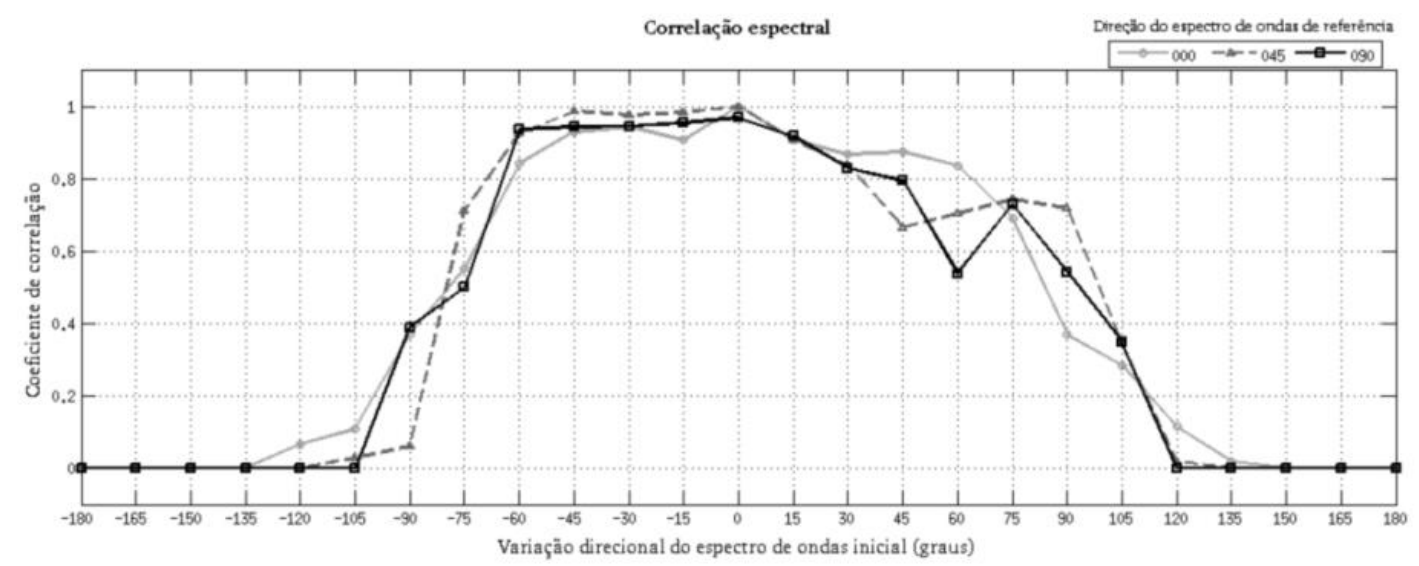

Figura 5: Representação da variação do coeficiente de correlação (adimensional) entre o espectro de ondas recuperado e o espectro de ondas de referência em função da direção principal do espectro de ondas inicial e da direção principal do espectro de referência relativamente a direção do voo do satélite.

$\mathrm{Na}$ análise feita a seguir, tenta-se estabelecer uma relação (percepção visual) do espectro de ondas recuperado e o seu grau de correlação com o espectro de ondas de referência. Partindose do espectro de ondas de referência com direção principal $45^{\circ}$, visto na Figura 6 , gera-se o espectro de imagem SAR apresentado na Figura 7, levando em conta a adição de um ruído aleatoriamente produzido. Este espectro de imagem SAR, correspondente à cena descrita pelo espectro de ondas de referência da Figura 6, será utilizado para recuperação de espectros. Os resultados obtidos pelo algoritmo MPI serão analisados quando as seguintes rotações do espectro de ondas de referência forem usadas como espectro de ondas inicial: $\Delta^{0}=$ : (i) $-30^{\circ}$; (ii) $0^{\circ}$; (iii) $45^{\circ}$; (iv) $-90^{\circ}$; (v) $-105^{\circ}$ e (vi) $150^{\circ}$.

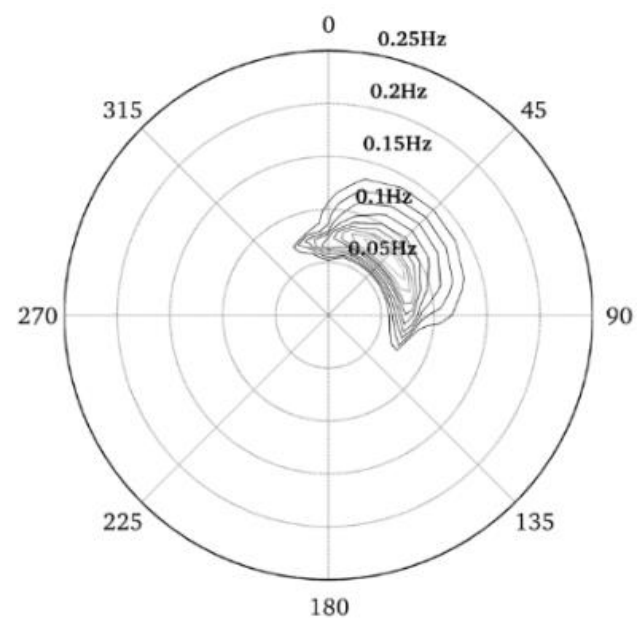

Figura 6: Espectro direcional de ondas (JONSWAP x $\cos ^{2 s}$ ) $\operatorname{com}$ direção principal de $45^{0}$, utilizado como espectro de ondas de referência numa das simulações. 


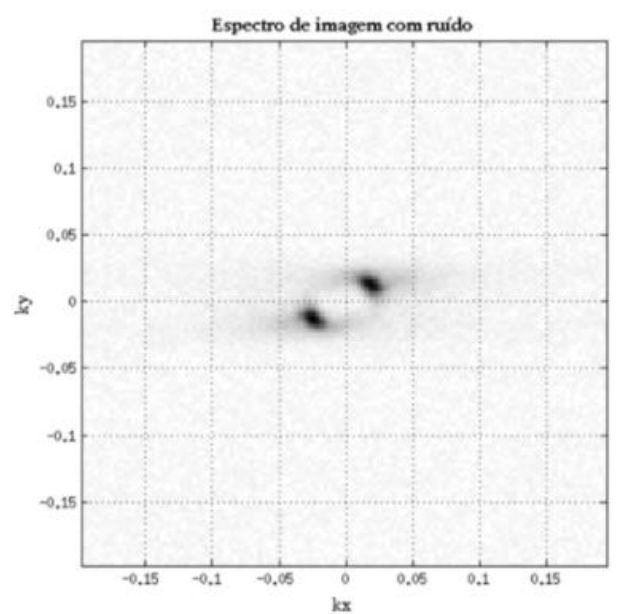

Figura 7: Espectro de imagem SAR com direções $45^{\circ}$ e $225^{\circ}$ (ambiguidade) gerado a partir do espectro de ondas referência da Figura 6.

(i) Neste caso o espectro de ondas inicial possui direção principal de $15^{\circ}$. O coeficiente de correlação entre o espectro de ondas recuperado e o espectro de ondas de referência é alto, aproximadamente 0.98. Isto garante grande similaridade entre estes espectros direcionais. Este fato é constatado rapidamente com uma inspeção visual entre os itens (a) e (c) da Figura 8. É importante observar que a direção principal do espectro de ondas recuperado é preservada, isto é, persiste muito proximamente a $45^{\circ}$, enquanto que a direção média sofre influência grande da direção principal do espectro de ondas inicial. Isto é percebido pela leve rotação (que é uma distorção) imprimida ao espectro de ondas recuperado se comparado ao espectro de ondas de referência.

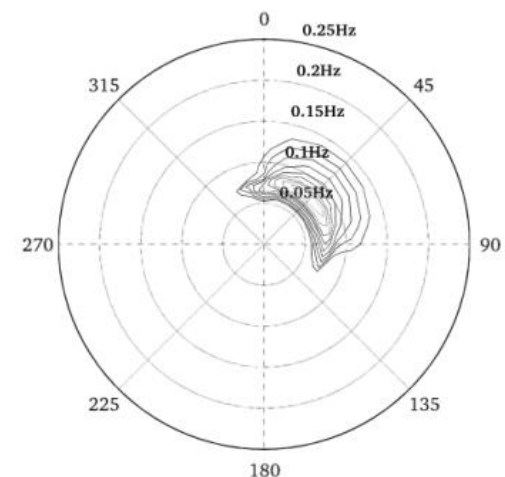

(a)

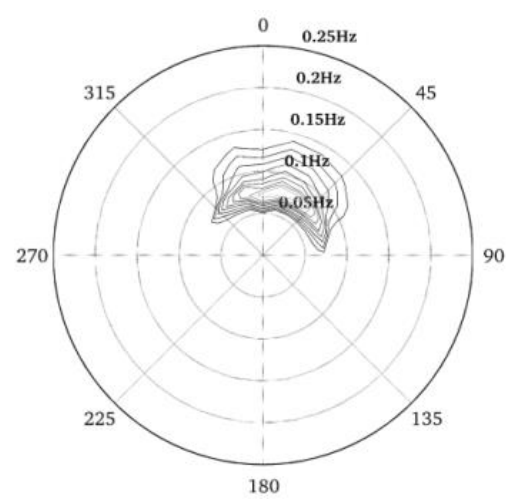

(b)

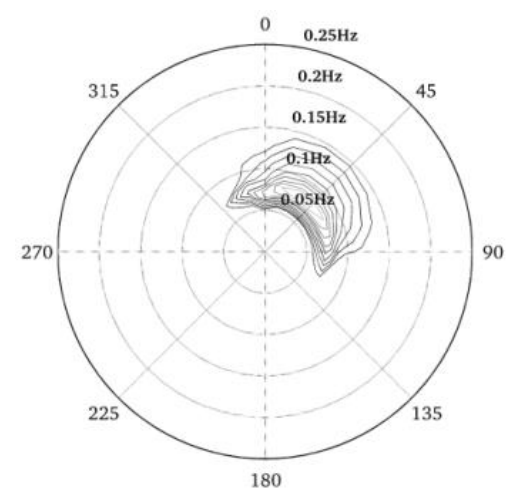

(c)

Figura 8: Caso $\Delta^{0}=-30^{\circ}$ : (a) espectro de ondas de referência; (b) espectro de ondas inicial; (c) espectro de ondas recuperado.

(ii) Neste caso, o espectro de ondas inicial é o próprio espectro de ondas de referência. $\mathrm{O}$ coeficiente de correlação entre o espectro de ondas recuperado e o espectro de ondas de referência é igual a 1. Isto garante que o espectro de ondas recuperado e o espectro de ondas de referência estão totalmente correlacionados. A comparação entre os itens (a) e (c) da Figura 9 não deixa dúvida quanto a esta conclusão. 


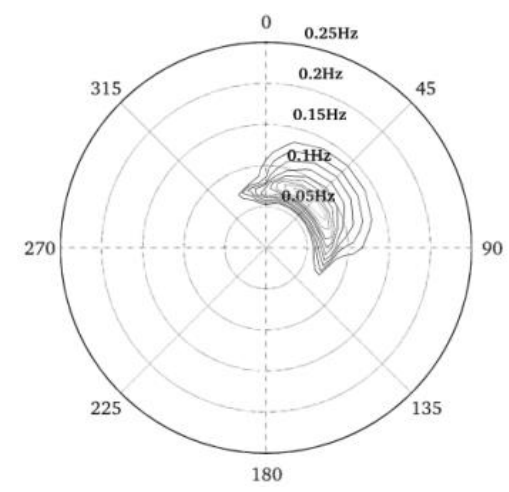

(a)

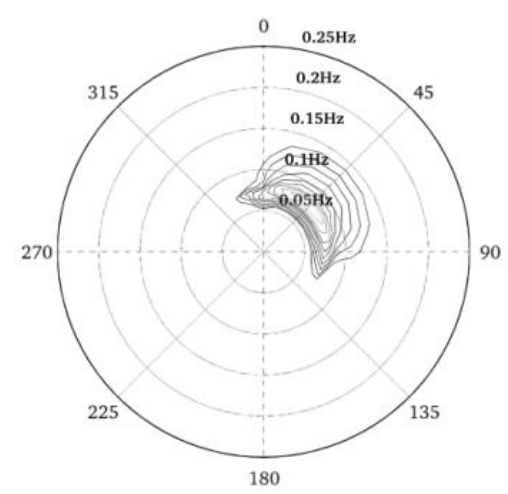

(b)

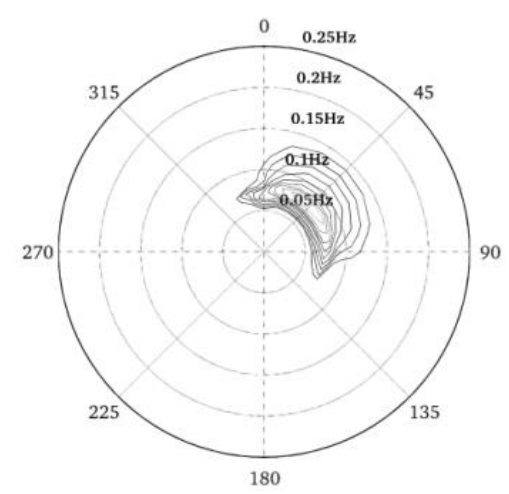

(c)

Figura 9: Caso $\Delta^{0}=0^{\circ}$ : (a) espectro de ondas de referência; (b) espectro de ondas inicial; (c) espectro de ondas recuperado.

(iii) Neste caso, o espectro de ondas inicial possui direção principal de $90^{\circ}$. O coeficiente de correlação entre o espectro de ondas recuperado e o espectro de ondas de referência é igual a 0.68. Uma inspeção visual constata que, de fato, a similaridade entre o espectro de ondas de referência e o espectro de ondas recuperado é bem menor. Como já observado, o espectro de ondas inicial impacta significativamente a direção média. Este fato pode ser reconfirmado comparando-se o espectro de ondas recuperado (Figura 10-c) com o espectro de ondas de referência (Figura 10-a): a direção média do espectro de ondas recuperado tende a acompanhar a direção principal do espectro de ondas inicial $\left(90^{\circ}\right)$.

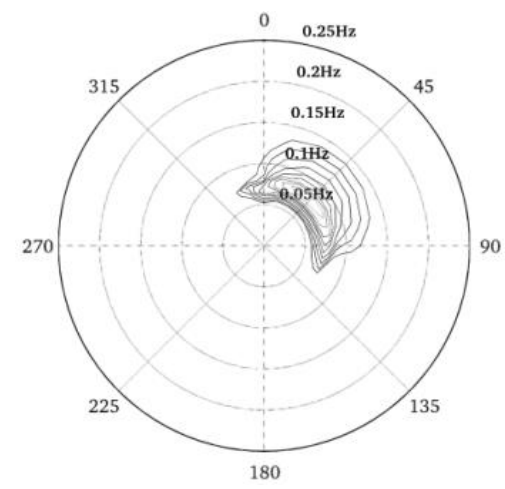

(a)

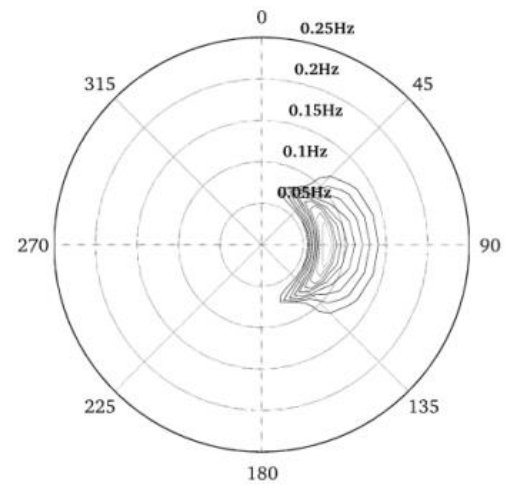

(b)

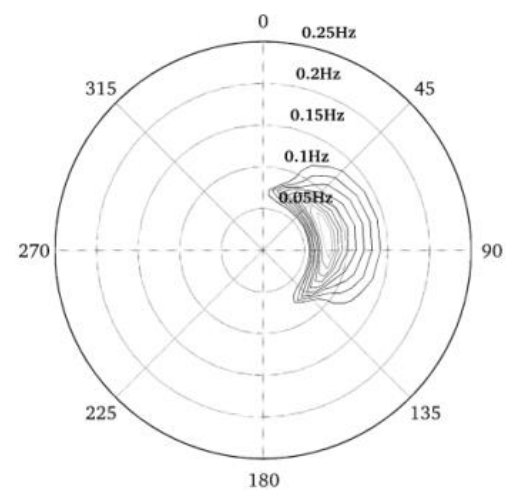

(c)

Figura 10: Caso $\Delta^{0}=45^{\circ}$ : (a) espectro de ondas de referência; (b) espectro de ondas inicial; (c) espectro de ondas recuperado.

(iv) Neste caso, o espectro de ondas inicial possui direção principal de $315^{\circ}$. O coeficiente de correlação entre o espectro de ondas recuperado e o espectro de ondas de referência decresce bastante e vale algo em torno de 0.06. A comparação visual entre os itens (a) e (c) da Figura 11 explica esta baixa correlação: a distorção é muito grande. Isto mostra em que medida uma escolha muito equivocada da direção principal do espectro de ondas inicial impacta os resultados obtidos. No presente caso e em outros não apresentados aqui, em que o espectro de ondas inicial possui direção principal aproximadamente ortogonal à direção do espectro de ondas de referência, a resposta exibida pelo mecanismo de inversão foi, invariavelmente, um espectro direcional particionado, o que corresponde a um sistema bimodal de ondas. Isto ocorre devido à baixa confiabilidade do espectro de ondas inicial em relação ao espectro de imagem, 
não sendo o mecanismo, portanto, capaz de decidir sobre a ambiguidade direcional com clareza. Por fim, cabe destacar que apesar da grande distorção entre os espectros em questão, o coeficiente de correlação entre eles só não é nulo devido ao sistema de ondas com direção principal próxima a $0^{\circ}$, que ainda preserva alguma característica do espectro de ondas de referência.

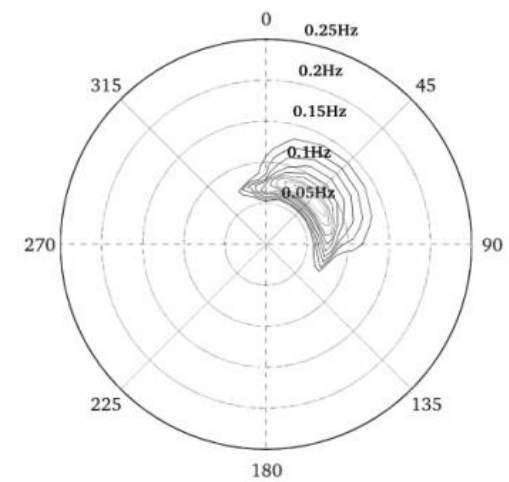

(a)

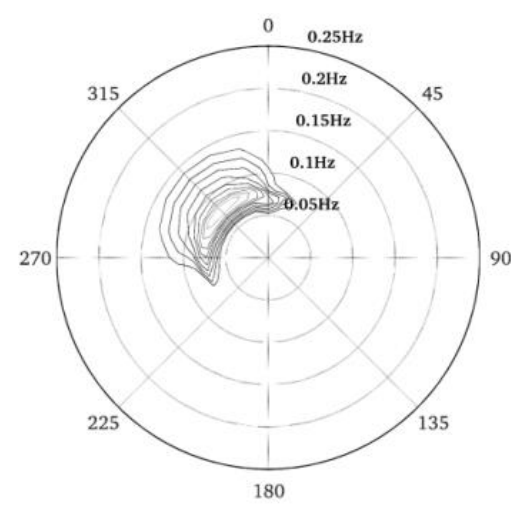

(b)

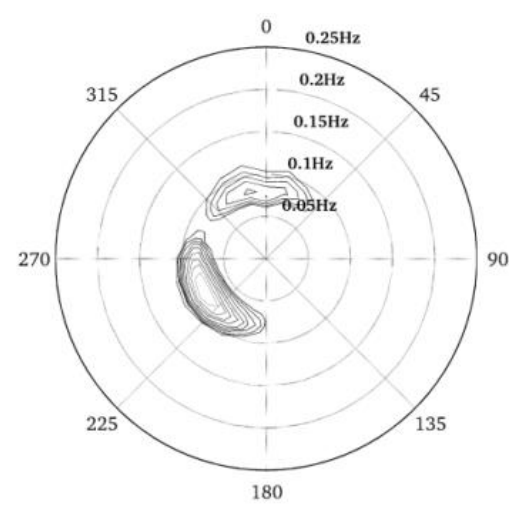

(c)

Figura 11: Caso $\Delta^{0}=-90^{\circ}$ : (a) espectro de ondas de referência; (b) espectro de ondas inicial; (c) espectro de ondas recuperado.

(v) Neste caso, o espectro de ondas inicial possui direção principal de $300^{\circ}$. O coeficiente de correlação entre o espectro de ondas recuperado e o espectro de ondas de referência é ainda menor: vale algo em torno de 0.028. A comparação visual entre os itens (a) e (c) da Figura 12 dá uma boa ideia sobre o baixo grau de similaridade entre os espectros direcionais em questão. Note-se que, como no caso (iv), há uma partição do espectro de ondas recuperado, pois a direção do espectro de ondas inicial é aproximadamente ortogonal à direção do espectro de imagem. $\mathrm{O}$ espectro de ondas recuperado neste caso guarda ainda menos características do espectro de ondas de referência, por isso seu grau de similaridade com o espectro de ondas de referência é ainda menor que o observado no caso (iv). É ilustrativo comparar os espectros de ondas recuperados nos casos (iv) e (v) tendo em mente a energia associada a cada um dos sistemas de ondas com direção principal próxima a $0^{\circ}$. Eles permitem compreender o decréscimo do coeficiente de correlação que ocorre nestes casos. 


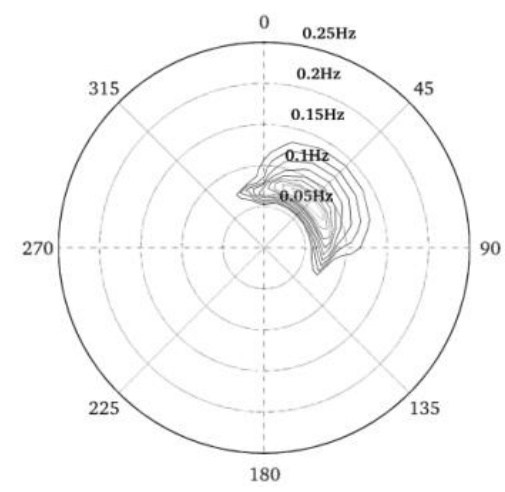

(a)

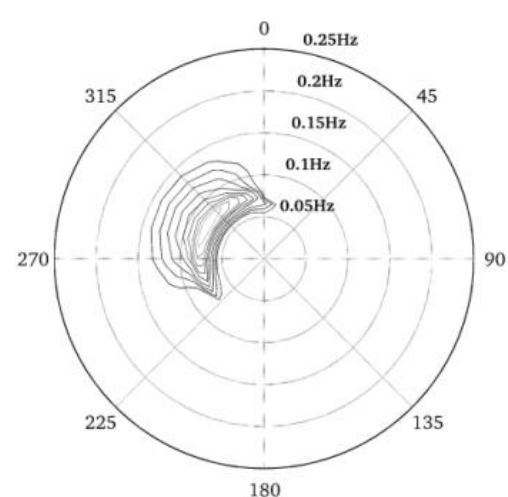

(b)

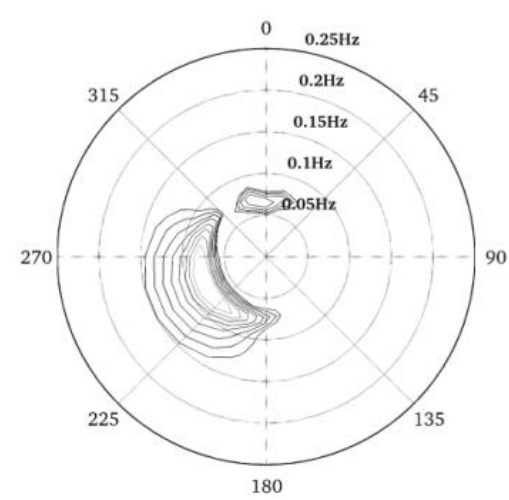

(c)

Figura 12: Caso $\Delta^{0}=-105^{\circ}$ : (a) espectro de ondas de referência; (b) espectro de ondas inicial; (c) espectro de ondas recuperado.

(vi) Neste caso, o espectro de ondas inicial possui direção principal de $195^{\circ}$. O coeficiente de correlação entre o espectro de ondas recuperado e o espectro de ondas de referência é zero, ou seja, não há correlação entre os espectros direcionais. A comparação visual entre os itens (a) e (c) da Figura 13 deixa muito claro que o espectro de ondas recuperado não guarda característica alguma do espectro de ondas de referência. Este resultado decorre da escolha de um espectro de ondas inicial com direção principal praticamente oposta à direção principal da direção do espectro de ondas de referência, levando o algoritmo de inversão basear-se nesta informação equivocada. $\mathrm{O}$ espectro de ondas de referência é o espelhamento deste espectro de ondas recuperado no primeiro quadrante.

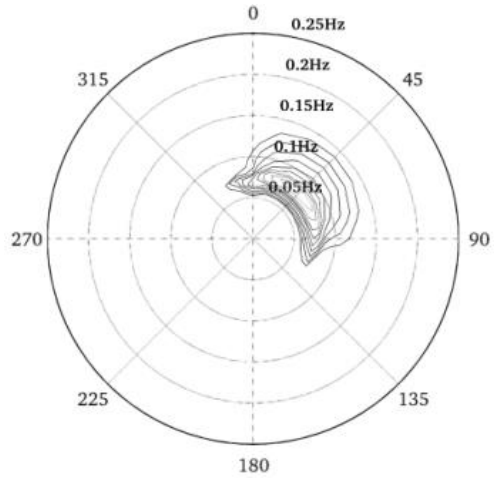

(a)

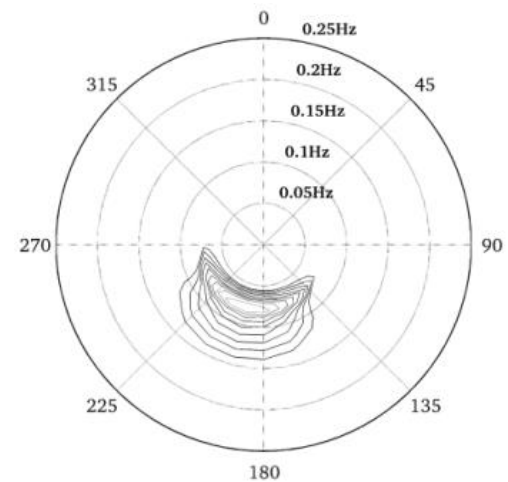

(b)

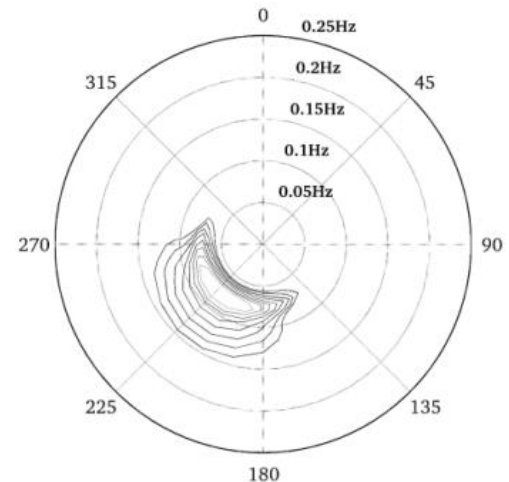

(c)

Figura 13: Caso $\Delta^{0}=150^{\circ}$ : (a) espectro de ondas de referência; (b) espectro de ondas inicial; (c) espectro de ondas recuperado. 


\section{CONCLUSÕES}

Neste artigo foi proposta uma nova metodologia para avaliar os impactos sofridos pelo espectro de ondas recuperado pelo SAR decorrentes da mudança da direção principal do espectro de ondas inicial. Os resultados obtidos para variações angulares da direção principal do espectro de ondas inicial em relação à direção principal do espectro de ondas de referência de até $60^{\circ}$ têm boa concordância com os reais valores dos parâmetros de onda utilizados como referência, além de alto grau de similaridade com o espectro de ondas de referência.

Para o estado de mar considerado, constata-se que a direção média das ondas do espectro de ondas recuperado é muito influenciada pela direção principal do espectro de ondas inicial. Diferentemente, a direção principal das ondas do espectro de ondas recuperado mostra-se bastante estável, desde que a direção do espectro de ondas inicial seja escolhida em uma das vizinhanças da direção do espectro de imagem SAR. Observa-se grande instabilidade deste parâmetro se a direção principal do espectro de ondas inicial é aproximadamente ortogonal à direção do espectro de imagem SAR. Isto não chega, entretanto, a ser uma surpresa, uma vez que um espectro de ondas inicial nestas condições não resolve a ambiguidade direcional.

O período de pico (assim como o período médio) não apresenta um comportamento bem definido nas simulações realizadas. Entretanto, este desvio mostrou-se limitado a, no máximo, $8 \%$. Isto corresponde a, aproximadamente, 1 segundo de defasagem em relação período do espectro de ondas de referência. Os resultados sobre os desvios da altura significativa não revelam, a princípio, um comportamento muito bem definido. Indicam, porém, que o desvio

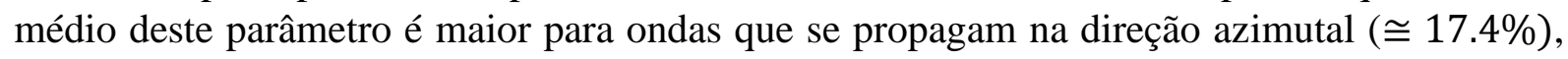

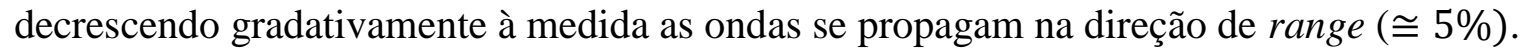

$\mathrm{O}$ mais importante resultado deste trabalho diz respeito à energia espectral. A energia do espectro de ondas recuperado correspondente a determinado estado de mar varia em função da direção principal do espectro de ondas inicial e da direção de propagação das ondas do sistema de ondas considerado. Especificamente, constatou-se que os maiores valores da densidade de energia do espectro de ondas recuperado são detectados quando a direção principal do espectro de ondas inicial tende a alinhar-se à direção do espectro de imagem SAR observado. De fato, os maiores valores da densidade de energia são verificados para sistemas de ondas que se deslocam paralelamente à direção de voo do satélite (azimutal), enquanto que para ondas que se propagam nas outras direções consideradas, estes valores são menos intensos. Isto indica como propor modificações acerca da energia do espectro de ondas inicial de forma a recuperar espectros de ondas com parâmetros de onda mais acurados e com maior correlação com o espectro de ondas de referência. Esta discussão sobre a energia espectral revela que a altura significativa é bastante sensível à variação da direção principal do espectro de ondas inicial, assim como é bem determinado o seu comportamento.

Conclui-se, portanto, que esta metodologia mostra-se muito promissora, pois com as devidas adaptações, ela pode ser utilizada na análise de sensibilidade do espectro de ondas recuperado a outros parâmetros de onda. Sua aplicabilidade pode ser facilmente estendida a situações reais, bastando para isto uma devida adequação. Sendo assim, é possível estimar erros na obtenção de parâmetros de ondas através do SAR e detectar como e quais fatores envolvidos neste processo afetam o resultado obtido. 


\section{AGRADECIMENTOS:}

Agradecimento a CAPES pela concessão de bolsa de estudo para Felipe Marques dos Santos, aluno do curso de doutorado do PPG-EM/UERJ.

\section{REFERÊNCIAS BIBLIOGRÁFICAS}

Abdalla S., Bidlot, J. R., Janssen, P. Global validation and assimilation of Envisat ASAR wave mode spectra. Proc. of SEASAR, Frascati, Italy, p. 1-8, 2006.

Aouf, L., Lefèvre, J-M., Hauser, D. Assimilation of Directional Wave Spectra in the Wave Model WAM: An Impact Study from Synthetic Observations in Preparation for the SWIMSAT Satellite Mission. J. Atm. and Oceanic Technology, 23, p. 448-463, 2006.

Cartwright, M. Fourier Methods for Mathematicians, Scientists and Engineers. United Kingdon, Ellis Horwood, p. 179-180, 1990

Collard, F., F. Ardhuin, B. Chapron. Extraction of coastal ocean wave fields from SAR images, IEEE Journal of Oceanic Engineering, 30(3): 526-533, 2005

Corsini, G. E Manara, G. Sea wave spectrum estimation from SAR images: a simulation based approach. Geoscience and Remote Sensing, 2: 936 - 938, 1995

Hasselmann, K. E Hasselmann, S. On the nonlinear mapping of an ocean wave spectrum into a synthetic aperture radar image spectrum and its inversion. Journal of Geophysical Reasearch, 96: 713 - 729. 1991.

Heiberg, H., Breivik, L-A., Reistad, M., Brattli, A. Use of ASAR wave spectra in operational wave analysis and forecasting, report 10, Norwegian Meteorological Institute. 2006.

Kasilingam, D.P. E Shemdin, O. H. Models for synthetic aperture radar imaging of the ocean: A comparison. Journal of Geophysical Research 95: 1010 -1029. 1990.

Kahma, K., Hauser, D., Krogstad, H., Lehner, S., Monbaliu, J., Wyatt, L. Measuring and analyzing the directional spectra of ocean waves, EU COST Action 174, EUR 21367, p. 19-20, 2005.

Komen, G. J., Cavaleri, L., Donelan, M., Hasselmann, K., Hasselmann S., Janssen, P. Dynamics and modelling of ocean waves. New York, Cambridge University Press, p. 390 - 393. 1994.

Krogstad, H. E Shyberg, H. On Hasselamann's nonlinear ocean-SAR transformation. Journal of Geophysical Reasearch, 97: 2421 - 2425, 1992.

Litovchenko, K. E Ivanov, A. Comparison of ERS-1 and ALMAZ-1 SAR ocean wave imaging. Geoscience and Remote Sensing, 3: 937 - 939. 1993.

Longuet-Higgins, M. S. The statistical analysis of a random, moving surface. Phil. Trans. R. Lond, 249: 321-387. 1957.

Phillips, O. M. The Dynamics of the Upper Ocean, Cambridge University Press, p. 99 - 103. 1977.

Robinson, I. S. Measuring the Oceans from Space. Great Britain, Springer-Praxis Books, p. 669. 2004.

Stewart, D. E. Dynamics with Inequalities. Philadelphia, SIAM, p. 41. 2011. 
Violante-Carvalho, N., Robinson, I., Gommenginger, C., Carvalho, L.M., F. Ocampo-Torres, J. The effect of the spatially inhomogeneous wind field on the wave spectra employing an ERS2 SAR PRI image, Continental Shelf Research (CRS), 36: 1-7. 2012.

WAFO-group (2000). "WAFO - A Matlab Toolbox for Analysis of Random Waves and Loads - A Tutorial" Math. Stat., Center for Math. Sci., Lund Univ., Lund, Sweden. Accessed 08/12/2014. http://www.maths.lth.se/matstat/wafo.

Wang, H ; Zhu, Jh ; Yang, Js ; Shi, Cy. A semiempirical algorithm for SAR wave height retrieval and its validation using Envisat ASAR wave mode data, Acta Oceanologica Sinica, 2012, 31(3): 59-66. 2012.

(Recebido em setembro de 2014. Aceito em dezembro de 2014). 


\title{
PROPOSAL OF A SEQUENTIAL METHOD FOR SPATIAL INTERPOLATION OF MODE CHOICE
}

\author{
Proposta De Um Método Sequencial Para Interpolação Espacial De Escolha \\ Modal
}

\author{
Cira Souza Pitombo ${ }^{1}$
}

Aline Schindler Gomes Da Costa ${ }^{2}$

Ana Rita Salgueiro 3

\begin{abstract}
'Universidade de São Paulo, Escola de Engenharia de São Carlos, Avenida dos Trabalhadores Sãocarlense, 400 - Parque Arnold Schimidt, 13566-590. São Carlos - SP, Brasil.

email:cira@sc.usp.br

2Universidade Federal da Bahia, Programa de Mestrado em Engenharia Ambiental Urbana - Escola Politécnica da Universidade Federal da Bahia - Rua Aristides Novis, 2 - 8ํandar - Federação, CEP 40.210-630, Salvador -Bahia.

email:schindler.aline@gmail.com

3Universidade Federal do Ceará, Departamento de Geologia, Universidade Federal do Ceará, Campus do Pici - Bloco 912 CEP 60440-900 Fortaleza - CE - Brasil.
\end{abstract}

email:geo.ritasalgueiro@gmail.com

\section{Resumo:}

O objetivo do presente trabalho é propor um método sequencial para interpolação espacial da escolha modal em domicílios não amostrados, através de técnicas de Árvore de Decisão e Geoestatística. Inicialmente, foi aplicada a técnica de Árvore de Decisão, com a finalidade de estimar a probabilidade de escolha do modo em domicílios pesquisados, determinando assim a variável numérica a ser krigada posteriormente. Os dados utilizados foram da Pesquisa OrigemDestino e da Pesquisa de Opinião sobre avaliação do transporte público, realizadas em 2007/2008 em São Carlos (SP). A área selecionada para modelagem geoestatística pelo estudo foi uma pequena região da cidade com 110 pontos amostrados. A escolha modal foi estimada na área estudada, revelando uma tendência de aumento da probabilidade do uso do carro do centro para a periferia da região. $\mathrm{O}$ método proposto pode ser uma alternativa às abordagens tradicionais, tanto na modelagem não-espacial, especialmente para o caso de falta de dados de pesquisa de preferência declarada, como em modelagem espacial, permitindo estimar valores em várias coordenadas geográficas.

Palavras-chave: Comportamento relacionado a viagens; Escolha Modal; Estimação Espacial; Krigagem Ordinária; Árvore de Decisão. 


\begin{abstract}
:
The main objective of this study is to propose a sequential method for spatial interpolation of mode choice for household locations where choices are unobserved based on Decision Tree analysis and Geostatistics. Initially, Decision Tree analysis was applied in order to estimate the probability of mode choice in surveyed households, thus determining the numeric variable to be estimated by Ordinary Kriging. The data used is from the Origin-Destination Survey and Urban Transportation Evaluation Survey, carried out in 2007/2008 in the city of São Carlos (São Paulo/Brazil). The study area selected for geoestatistical modeling is a small region of the city with 110 sampling points. The mode choice was estimated for the study area revealing a tendency of increasing the probability of car usage from the center to the periphery of region. The proposed method can be an alternative to traditional approaches in both non-spatial modeling, especially for the case of lack of data from stated preference survey, as in spatial modeling, allowing estimation in various geographic coordinates.
\end{abstract}

Keywords: Travel Behavior; Mode Choice; Spatial Estimation; Ordinary Kriging; Decision Tree Analysis.

\title{
1. Introduction
}

Individuals choose their travel mode considering diverse factors, classified into three groups: (1) Characteristics of the trip maker; (2) Characteristics of the journey; (3) Characteristics of the transport facility. Thus, travel behavior involves household and personal characteristics, travel variables and spatially correlated factors (Ortúzar and Willumsen, 2011).

Several works corroborate the assertion that travel behavior, especially for the case of mode choice, is strongly related to locations, characterized by urban density - compact vs. spread- out cities -, distribution of economic activities and presence of Traffic Analysis Zones (TAZ) with mixed activities (Cervero and Radisch, 1996; Kitamura et al., 1997).

With the advances of technology, geo-referenced information has become more widely available. Travel demand spatial analysis has been identified as an emerging research area (Páez et al., 2013), hence it is now possible to take in account the variables spatial influence and, consequently, incorporate space more effectively into travel.

Recently, researchers have found that travel behavior exhibits signs of spatial interdependence. Bhat and Zhao (2002) identified the spatial issues that need to be recognized in demand modeling, proposing a multi-level, mixed logit, formulation to address these spatial issues in the context of activity stop generation in the Boston Metropolitan area. Páez et al. (2013) introduced a new indicator of spatial fit that can be applied to the results of discrete choice models. Peer et al. (2013) applied geographically weighted regression for the approximation of door-to-door travel times in departure time choice models.

Among the techniques of spatial analysis, geostatistics is to be highlighted. Geostatistics enables the development of studies involving spatial autocorrelation, allowing mainly estimating the value of a variable in locations where values are unobserved.

The objective of this study is to propose a sequential method to estimate the mode choice in known geographical coordinates (sampled households) and also in non-sampled households. 
The method is composed of a sequential application of Decision Tree (DT) analysis and Ordinary Kriging (OK). The DT model estimates probabilities of mode choice in known coordinates. Besides, DT analysis determines the variable to be kriged in the later stage. The OK application can be conducted only with numerical variables - the probabilities estimated by DT model. The OK was applied in one region of the study area. Geo-referenced disaggregated data were used in this work.

The proposed method can be an alternative to traditional approaches. It consists of two main steps: a non-spatial and a spatial model. Decision Tree analysis is presented here as an alternative to traditional econometric models. In spatial modeling stage, the Ordinary Kriging works as a technique that presented a major advantage over other spatial confirmatory techniques as Geographically Weighted Regression, for example. The OK allows estimating probabilities of choice in places not surveyed.

The next section summarizes the recent literature regarding transport and geostatistics and data mining and travel mode choices. The section 3 describes the rationality of the proposed method. In Section 4 DT and OK results are presented, as well as detailed discussions. Finally, the last section presents the work's general conclusions.

\section{Background}

\subsection{Geostatistics and Transport}

There are few applications of geostatistical methods on transportation data and all of them are recently. Is to be noted that most papers available refers to traffic engineering studies (Ciuffo and Punzo, 2011; Mazzella et al., 2011). Miura (2010) presents an approach for predicting car travel time by kriging with good results, indicating that $95 \%$ prediction limits are between \pm 10 minutes and \pm 30 minutes for travel between two arbitrary points. This prediction method is effective for urban districts with links having changeable travel time.

Zou et al. (2012) proposed an improved distance metric called approximate road network distance (ARND), for solving the problem of the invalid spatial covariance function in kriging caused by the non-Euclidean distance metric. Wang et al. (2012) proposed to solve the traditional research method of statistics on the floating car speed with geostatistics. The spatial structure and the interpolation of floating car speeds are analyzed by exact floating car speed data of the study area in Beijing in May 2005.

However, the use of geostatistics in problems concerning the transportation demand or travel behavior is extremely recent (Gi and Gao, 2010; Peer et al., 2013; Pitombo et al., 2010; Pitombo et al., 2015)). So, the focus of this paper is to present not so trivial techniques in the study of travel behavior, for estimation of mode choice, incorporating spatial factors. 


\subsection{Data mining and Travel Mode Choices}

For decades, until nowadays, authors have been investigating the factors that influence mode choice, through different models, such as logit, probit and techniques of data collection as stated preference and revealed preference (Sen et al., 1978.; Ahern and Tapley, 2008).

Most traditional mode choice models are based on the principle of random utility maximization derived from econometric theory. In addition to the econometric techniques used to estimate travel behavior and mode choice, there are several studies that used data mining techniques to investigate the travel behavior. Mode choice modeling can be regarded as a pattern recognition problem in which multiple human behavioral patterns reflected by explanatory variables determine the choices between alternatives (Xie et al., 2007).

Xie et al. (2007) investigates the performance of two emerging pattern recognition data mining methods, decision trees (DT) analysis and neural networks (NN), for work travel mode choice modeling. Shmueli et al. (1996) explored the application of neural networks to a behavioral transportation planning problem. The transportation issue explored is a comparison of travel demand patterns of men and women in Israel. Pitombo et al. (2011) analyzed relationships between socioeconomic, land use, activity participation and travel patterns with Decision Tree (Classification and Regression Tree algorithm) modelling.

The first step of the method here presented is to estimate mode choice, considering socioeconomic variables and measures of the transport system quality, by applying the technique of Decision Tree Analysis (Classification and Regression Tree algorithms). Analysis of DT may be an alternative approach to traditional econometric models because, despite being a nonparametric technique, has no constrains related to input variables (categorical, numeric or dummy) and do not have assumptions such as normality, linearity and multicollinearity. Moreover, it has a high percentage of success even in conditions which are known only socioeconomic variables, with information relating to individuals and not to alternatives.

\section{Material And Method}

To reach the goal of this work, the stages of the proposed method, summarized in the subsequent subsections, have been fulfilled.

\subsection{Data Base Treatment}

The study area of this work is the city of São Carlos (São Paulo/Brazil), with 221,936 inhabitants. $96 \%$ of the population lives in urban areas, which covers, approximately, $105 \mathrm{~km}^{2}$ of 1137.30 $\mathrm{km}^{2}$ of total area (IBGE, 2010).

The data used for the development of this work is from the Household interview and Urban Transportation Evaluation Survey applied together in Origin-Destination Survey of 2007/2008 in the city (Rodrigues da Silva, 2008). 5\% of households was randomly selected. The Urban Transportation Evaluation Survey, which contains qualitative data of the transportation system of São Carlos, was applied to a resident of each household interviewed, in a total of 2,791 cases. This database, associated with the household interview was used as the basis for data processing and obtaining the final sample of this study. 
The database preliminary analysis process led to the elimination of some samples when one, or more, of the following situations occurred: (1) inconsistent or missing data, (2) people who did not travel and (3) households with repeated geographic coordinates. Thus, the final sample contains 1,216 individuals, 22 categorical variables and 4 numeric variables. Such information was then associated with geographic coordinates (latitude and longitude in meters) relative to the households. The main variables in the sample and its description can be found in Table 1.

\subsection{Decision Tree Analysis application - Determining the Numeric Variable}

Decision Tree (DT) analysis, especially the CART algorithm, is a simple representation for the existing relationship within a data set (dependent variable - independent variables). It consists of a sequential binary partitioning of the dataset considering the values of the variables. Tree models are fitted by successively splitting the data to form homogeneous subsets, being the result a hierarchical tree of decision rules useful for prediction or classification (Breiman et al., 1984).

CART is a segmentation modeling technique that satisfies the following properties: (a) The hierarchy is called tree and each segment is known as node; (b) The root node contains the complete database; (c) The root node is divided sequentially, generating child nodes; (d) When no further data subdivision is possible, the final subgroups are considered terminal nodes or leaves;(e) For construction of the CART, three main elements should be determined: a set of questions delimiting data division, a criterion for evaluation of the best division and a rule for termination of the further subdivisions (stop-splitting rule).

The CART application in this work was used to investigate the variables that contribute to understand individual mode choice. Another key objective for the use of DT analysis was the achievement of the continuous variable for application of Ordinary Kriging- mode estimated probabilities of travel modes.

The geostatistics technique used in the next step of this work, consists of using numeric variables, avoiding the use of the original categorical variable "main travel mode" for the spatial interpolation of mode choice.

Accordingly to the above described, the DT analysis was generated with a sample of 1,216 cases, using the CART algorithm and adopting the parameter of a minimum of 25 observations per terminal node (the stop-splitting rule considering the sample size and the desired homogeneity of the groups). The dependent variable was "Main travel mode", consisting of three categories (1 transit, $2 \mathrm{car} / \mathrm{motorcycle}$ and 3 non-motorized). The independent variables were socioeconomic, travel characteristics and the qualitative measures of transport system, as shown in Table 1.

\subsection{Spatial Patterns Analysis}

Following the steps of the proposed method, exploratory maps of probabilities of travel mode choice, obtained by DT model, were generated in order to observe spatial patterns. Good estimates for spatial interpolation depend, mainly, on spatial structure of the variable to be kriged. Figure 1, Figure 2 and Figure 3 present the spatial distribution of the probabilities of choosing the private motorized mode, transit and non-motorized travel mode, respectively, derived DT modelling.

From the exploratory spatial analysis (Figure 1, Figure 2 and Figure 3), was verified that the variables to be kriged did not present apparent spatial pattern. Thus, it was decided to segregate 
the city of São Carlos (São Paulo - Brazil) into small regions, considering the criteria of income, with the objective of defining spatial patterns on smaller regions.

As a result, the Cluster Analysis technique was applied considering the variable income (categorical, by Minimum Wages) and geographic coordinates of households (latitude and longitude in meters). A Two-Step Cluster method was adopted for a total of six groups / regions (Figure 4). The legend shows the percentage of households in the lowest income range (0-2 Minimum Wages) in each region. A detailed analysis of the probability maps for each of the six regions separately, revealed that Region 2 was the one that presented a more diffusive spatial pattern, ranging from the center to the periphery of the area, as shown in Figures 5 ( $a, b$ and c).

Table 1: Main variables.

\begin{tabular}{l|l}
\hline Variables & Description \\
\hline $\begin{array}{l}\text { Main problem - non } \\
\text { motorized mode }\end{array}$ & $\begin{array}{l}\text { (1) risk of running over ; (2) robberies; (3) poor } \\
\text { condition of sidewalks; (4) lack of trees }\end{array}$ \\
\hline Transit Capacity & (1) empty; (2) suitable; (3) crowded; (4) overcrowded \\
\hline Transit Fleet & (1) very small; (2) small; (3) suitable; (4) upper \\
\hline $\begin{array}{l}\text { Main problem - transit } \\
\text { mode }\end{array}$ & $\begin{array}{l}\text { (1) travel time; (2) safety; (3) comfort; (4) itinerary; (5) } \\
\text { schedules }\end{array}$ \\
\hline Main problem - car mode & (1) traffic jam; (2) lack of parking; (3) high cost \\
\hline Driver license & (1) yes; (2) no \\
\hline Gender of household head & (1) male; (2) female \\
\hline Literacy & $\begin{array}{l}\text { (1) complete high school degree or college; } \\
\text { incomplete high school degree or less; (3) illiterate }\end{array}$ \\
\hline Income & $\begin{array}{l}\text { (1) 0 to 2 MW*; (2) 2,1 to 8 MW*; (3) 8,1 to 20 MW*; } \\
\text { (4) not answered }\end{array}$ \\
\hline Main travel mode & (1) public; (2) private; (3) non-motorized \\
\hline Motorcycle ownership & number of motorcycles \\
\hline Car ownership & number of cars \\
\hline Age & household's head age \\
\hline Amount of trips & number of trips performed by the household head \\
\hline & \multicolumn{1}{|c}{ MW* Minimum Wage } \\
\hline
\end{tabular}




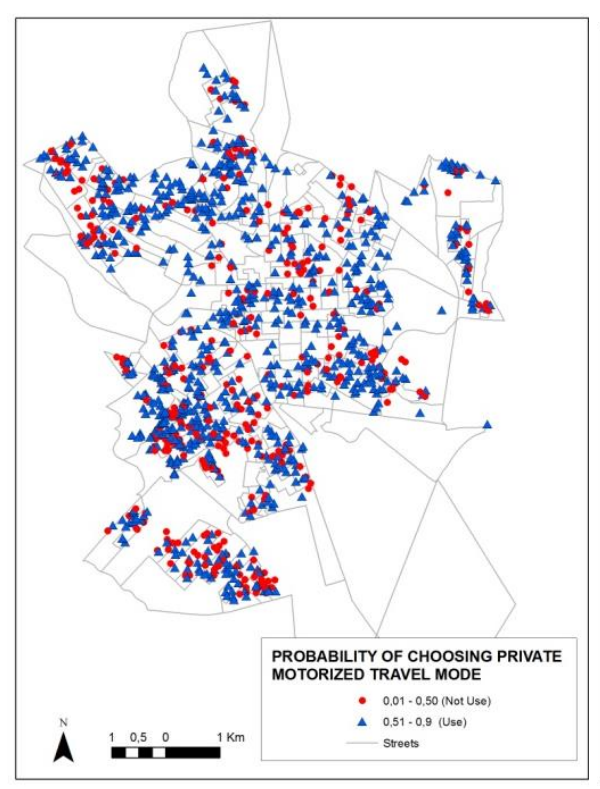

Figure 1.

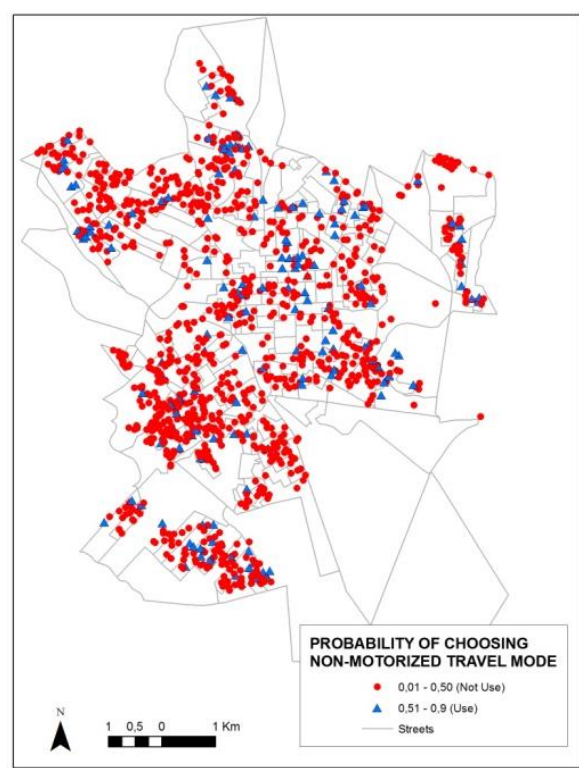

Figure 3.

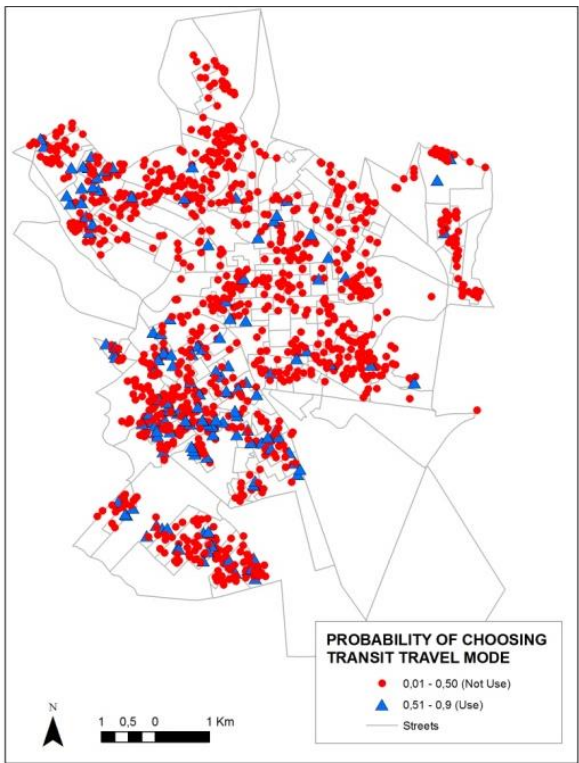

Figure 2.

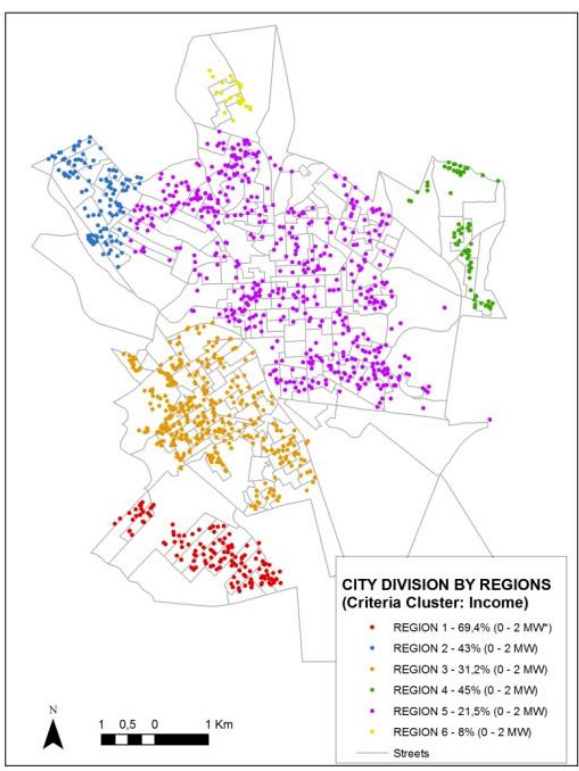

Figure 4.

This region consists of both low-income households (center of the region) and higher income (peripheral neighborhoods). In addition, Region 2, is a particular one in the city hence it includes the University of São Paulo second campus, an important factor that affects the city dynamics.

Therefore, in order to estimate all the area of Region 2 (Santa Felicia), including the locations where mode choice was not observed, a database composed by 110 points was submitted to Ordinary Kriging.

For purposes of geostatistics modelling validation, around $30 \%$ of points were randomly selected for model test. Resulting in 30 points selected for regions 2 to be used in cross validation. Crossvalidation allows the validation of the estimated values at the same time as assesses the goodness of the fitted parameters used. 


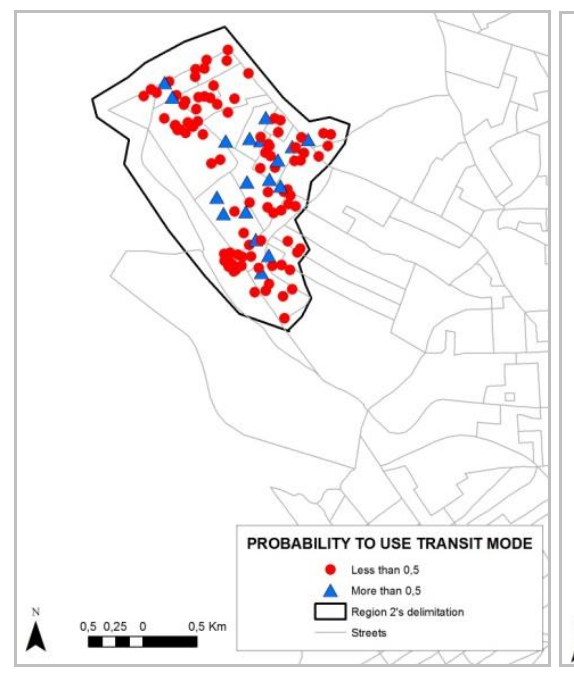

Figure 5 - a.

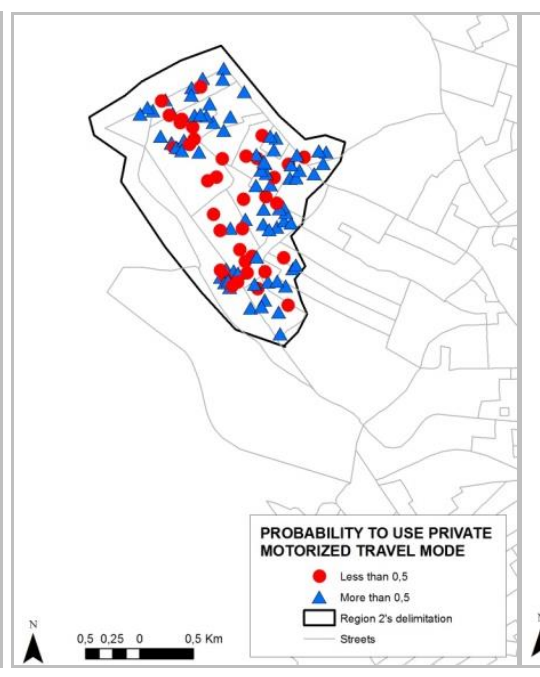

Figure 5 - b.

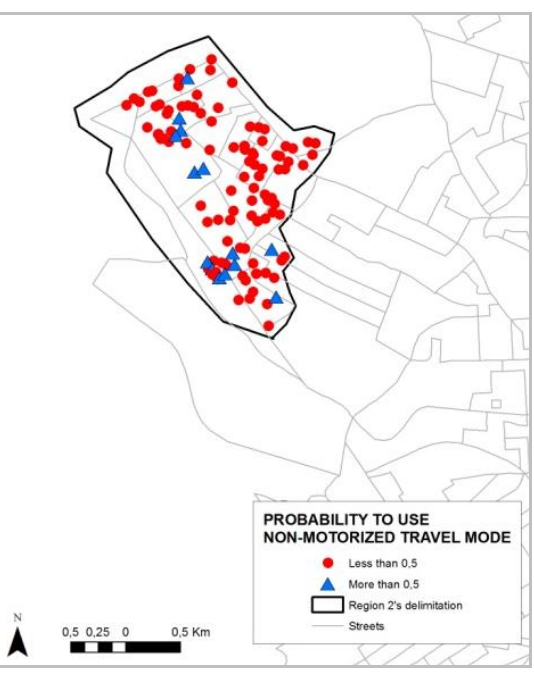

Figure 5 - c.

\subsection{Ordinary Kriging (OK) Application}

\section{a) Choice of Regionalized Variables}

Geostatistics, in general, works with data that has a spatial structure. If, for example, measurements are taken at two different points, differences in the measured values decreases as the two points come closer to each other (Matheron, 1971). The variables, called regionalized, are distributed in space and composed as random functions having a given spatial structure, or, in other words, having a given spatial correlation. The study of regionalized variables starts from the ability to interpolate a given field starting from a limited number of observations, but preserving the theoretical spatial correlation (Goovaerts, 1997).

In this paper, three regionalized variables were used, which have been obtained from Decision Tree Modelling: i) probability of choosing the car, ii) probability of choosing a non-motorized travel mode; iii) probability of selection of transit.

\section{b) Variogram}

The empirical variogram allows the quantitative representation of the variation of a regionalized variable in space. The variogram generates information used in kriging algorithm. The variogram function is defined as half the average square difference between points separated by a distance $\mathrm{h}$ (Matheron, 1963). The variogram function is calculated as.

$$
\gamma(h)=\frac{1}{2 N(h)} \sum_{i=1}^{x(k)}\left[z\left(x_{i}\right)-z\left(x_{i}+h\right)\right]^{2}
$$

Where $N(h)$ is the set of all pairwise; $z(x i)$ and $z(x i+h)$ are data values at spatial locations $i$ and $\mathrm{i}+\mathrm{h}$, respectively.

After obtaining the experimental variograms, a mathematical function is to be fitted, the one that best represents the variability in study. Of the various theoretical models for adjustments of variogram, the most frequently used are Spherical, Gaussian and Exponential. In this step, the 
experimental variogram is replaced by a theoretical variogram function, from which is possible to obtain the main parameters for spatial modelling: nugget effect (C0), Range (a) and Sill $(\mathrm{C}+\mathrm{C} 0)$, see Figure 6.

In this work, experimental variograms (constructed based on observed points) for the three variables obtained by DT analysis were constructed and theoretical models were adjusted with spherical functions.

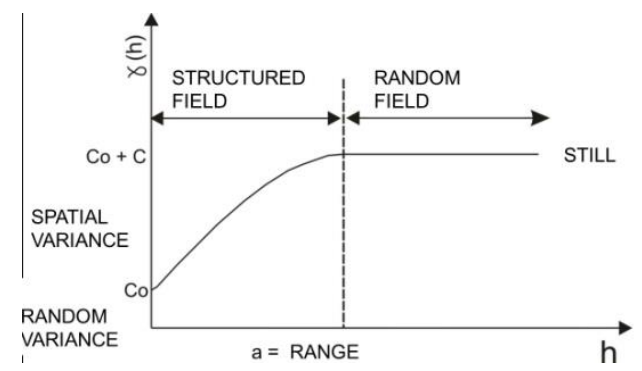

Figure 6: Variogram representing the variable's spatial behavior

Table 2 summarizes the parameters of the theoretical variograms for each regionalized variable for Region 2. Figure 7 ( $a, b$ and $c$ ) illustrates only the theoretical variograms in the main direction for the three regionalized variable for Region 2: Probabilities of private motorized travel mode; Probabilities of transit and Probabilities of non-motorized travel mode.

Table 2: Summary of the parameters of the theoretical variograms

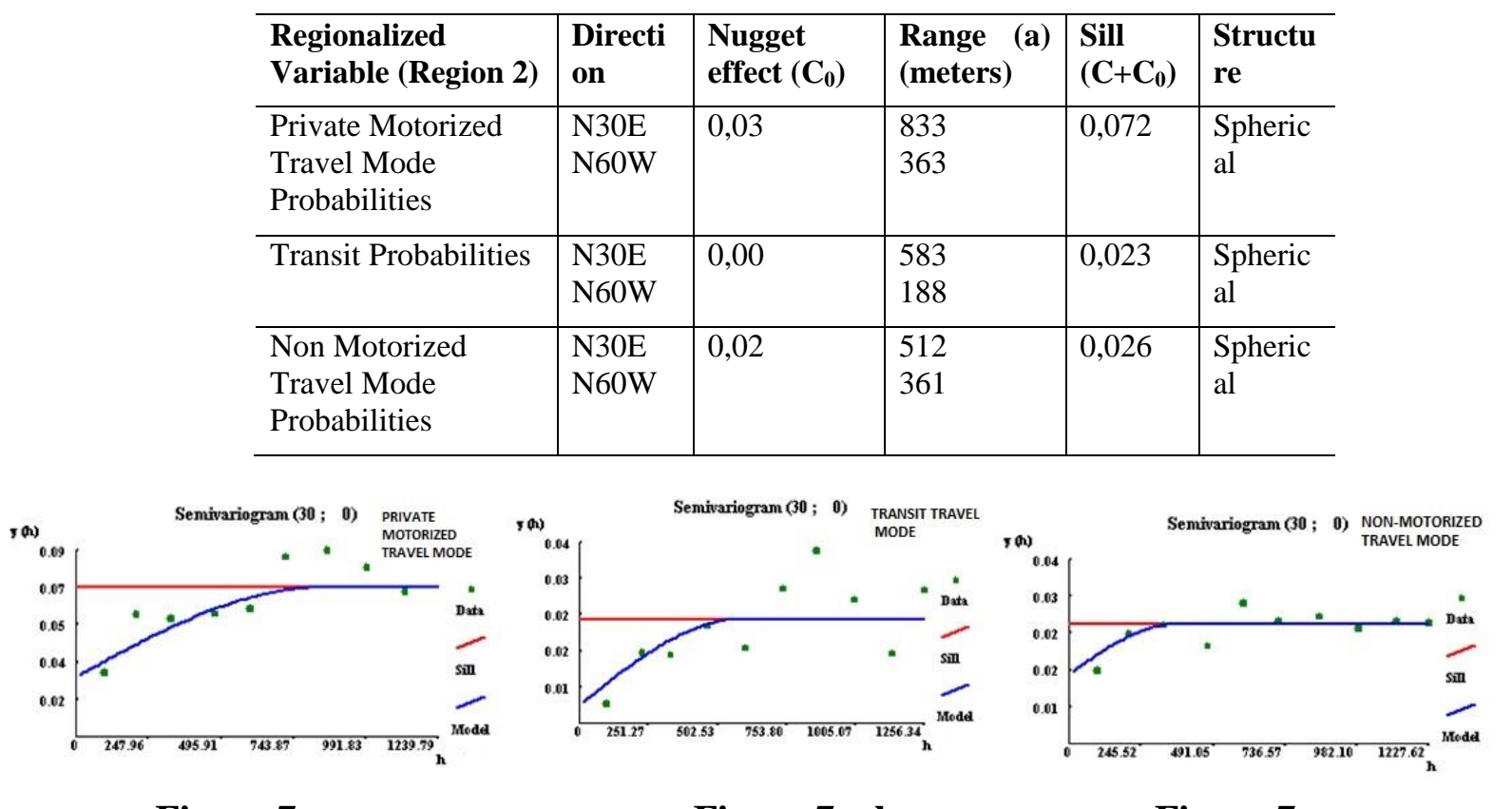

Figure $7-\mathbf{a}$.

Figure $7-b$.

Figure 7 - c.

\section{c) Cross Validation}

Cross Validation is a simple way to compare various assumptions either about the model (e.g. type of function to be adjusted, parameters of variograms) or about the data. In the cross validation procedure, each sample value $Z(x i)$ is removed in turn from the data set and a value $\mathrm{Z}^{*}(\mathrm{xi})$ at the location is estimated using the remaining $\mathrm{n}-1$ samples. The difference between a data value and the estimated value $\left(\mathrm{Z}(\mathrm{xi})-\mathrm{Z}^{*}(\mathrm{xi})\right)$ gives an indication of how well the data value fits into the neighborhood of the surrounding data values (Wackernagel, 2010). 
In order to assess the accuracy of the model determined in theoretical variograms, parameters such as correlation coefficient, mean of residuals and variance of errors, were calculated taking in account the observed and estimated values (30 points randomly selected for Regions 2 ).

\section{d) Ordinary Kriging (OK)}

Ordinary Kriging is the most widely used kriging method. Its main goal is to estimate a value at a point of a region, for which the correspondent variogram is known, using data in neighborhood (Wackernagel, 2010). OK is a method that is often associated with the acronym B.L.U.E. for "best linear unbiased estimator". OK is linear because its estimates are weighted linear combinations of the available data. It is unbiased since it tries to have the mean residual equal to zero. It is best because it aims at minimizing the variance of errors (Isaaks and Srivastava, 1989). For the prediction of the variable $\mathrm{Z}$ at a location $\mathrm{x} 0,\{\mathrm{Z}(\mathrm{x} 0)\}$, the estimator $\mathrm{Z}^{*}(\mathrm{x} 0)$ is defined as (Goovaerts, 1999):

$$
Z^{*}\left(x_{0}\right)=\sum_{i<}^{\infty} \lambda_{i} Z\left(x_{l}\right)
$$

where the $\lambda \mathrm{i}$ are weights found by solving the system of equations,

$$
\left\{\begin{array}{l}
\sum_{i}^{n} \lambda_{i} \gamma\left(x_{i}, x_{i}\right)+\mu=\gamma\left(x_{i}, x\right), i=1, \ldots, n \\
\sum_{i}^{n} \lambda_{t}=1
\end{array}\right.
$$

With $\gamma_{(h)}$ being the theoretical model for the variogram of the variable $\mathrm{Z}$ (fitted to the sample variograms) and $\mu$ being a Lagrange multiplier.

For the interpolation by $\mathrm{OK}$ of the three choice probabilities of travel mode, a grid of $100 \times 100$ meters was established, being its dimensions based on the distance between households in the study area. Kriging maps were generated by interpolation for the three travel modes.

\section{Discussions And Conclusion}

\subsection{Results of DT: Determining the Numeric Variables to be Kriged}

The DT, shown in Figure 8, illustrates that the majority of respondents use private motorized mode $(60.6 \%)$, then the non-motorized mode $(21.2 \%)$ and transit (18.2\%). Here is also possible to observe the variables selected for DT model and their relationship with mode choice. The most important variable (which best explains the data variability considering mode choice) was "Driver's License", splitting data into 2 main branches:

(1) Individuals that have driver's license (Node 1-74.6\% - uses car/motorcycle, $13.0 \%$ uses nonmotorized mode and $12.4 \%$ uses transit); (2) Individuals that do not have driver's license (Node $2-44.6 \%$ uses non-motorized mode, $34.7 \%$ transit and $20.7 \%$ uses car/motorcycle). 
The selection of "Driver license" as the most important variable in travel mode decision could be justified by the strong correlation of this variable and income and car ownership. These variables are known to have robust influence on mode choice.

Subsequently, CART algorithm fragmented dataset into groups. The groups were then divided successively considering the independent variables values. At the end of data segregation 11 terminal nodes were obtained. The terminal nodes are the basis to evaluate travel behavior.

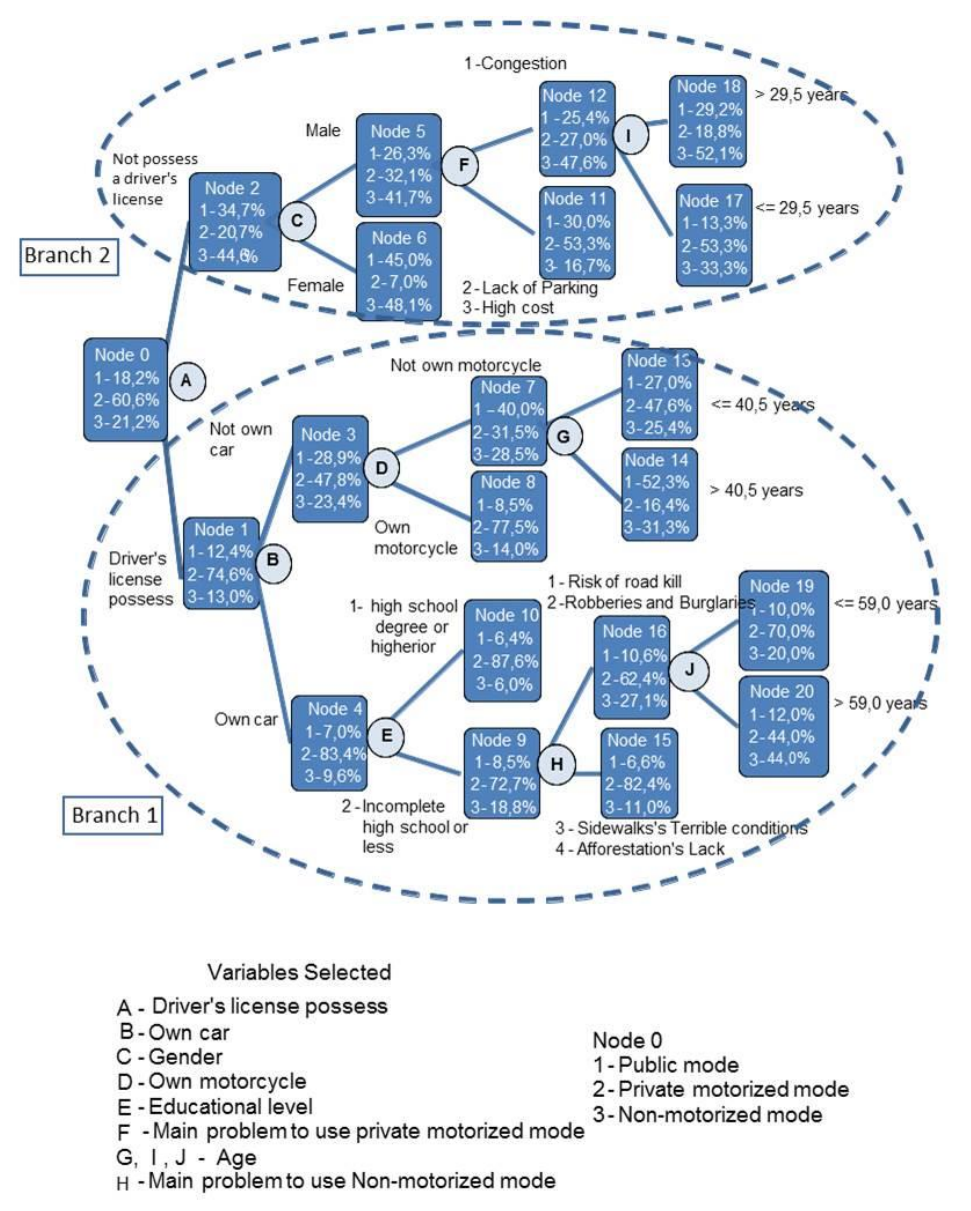

Figure 8: Decision tree - The most used transport's mode (dependent variable)

Therefore, one can observe the relationship of the following variables on car/motorcycle use: having driver license, having car or motorcycle at home, being below 59 years old, being male and being worried with the lack of parking and high cost car travel. Table 3 summarizes the relations (effects) of each variable on choosing travel mode, considering the 11 terminal nodes obtained. DT models also presented a good accuracy: $78 \%$ for private motorized mode, $83 \%$ for transit and $80 \%$ for non-motorized mode. 
Table 3: Variables selected by DT and their relationship on mode choice

\begin{tabular}{l|l|l|l}
\hline $\begin{array}{l}\text { Variables selected by } \\
\text { DT }\end{array}$ & Car/motorcycle & Transit & Non motorized \\
\hline Driver License & yes & no & no \\
\hline Car ownership & at least one car & zero car & zero car \\
\hline Motorcycle ownership & at least one motorcycle & zero motorcycle & zero motorcycle \\
\hline Age & $<=59$ & $>40$ & $>59$ \\
\hline Gender & Male & Female & Female \\
\hline Literacy & $\begin{array}{l}\text { complete high school } \\
\text { degree or college }\end{array}$ & high school/ illiterate & high school/ illiterate \\
\hline $\begin{array}{l}\text { Main problem - car } \\
\text { mode }\end{array}$ & lack of parking/high cost & lack of parking/high cost & traffic jam \\
\hline $\begin{array}{l}\text { Main problem - non } \\
\text { motorized mode }\end{array}$ & $\begin{array}{l}\text { risk of running over } \\
\text { /robberies }\end{array}$ & $\begin{array}{l}\text { poor condition of } \\
\text { sidewalks/lack of trees }\end{array}$ & $\begin{array}{l}\text { poor condition of } \\
\text { sidewalks/lack of trees }\end{array}$ \\
\hline
\end{tabular}

For the analysis with Ordinary Kriging, the results of the DT model were used as regionalized variables: Probability of choosing the car/motorcycle, Probability of choosing transit and Probability of choosing the non-motorized travel mode. These data are linked to geographic coordinates of 110 samples of Regions 2.

\subsection{Results of Ordinary Kriging}

As previously mentioned, approximately $30 \%$ of the samples of each region was randomly selected for cross-validation purposes, which allowed obtaining for 30 surveyed points in regions 2 , the correspondent estimated values according to probability of travel mode based on the determined variograms.

In order to access quality of obtained models some statistical parameters, such as correlation coefficient, mean of residuals and variance of errors, were calculated and can be observed in Table 4. In addition, the percentage of correct estimation of travel mode, considering the estimated and observed probabilities of travel mode, was also obtained.

\begin{tabular}{l|l|l|l|l} 
Table 4: Cross-Validation parameters \\
$\begin{array}{l}\text { Regionalized } \\
\text { Variables/Region 2 }\end{array}$ & $\begin{array}{l}\text { Correlation } \\
\text { Coefficient }\end{array}$ & $\begin{array}{l}\text { Mean of } \\
\text { Residuals }\end{array}$ & $\begin{array}{l}\text { Variance } \\
\text { of Erros }\end{array}$ & $\begin{array}{l}\text { \% Correct } \\
\text { Estimation }\end{array}$ \\
\hline $\begin{array}{l}\text { Private Motorized Travel } \\
\text { Mode Probabilities }\end{array}$ & 0,202 & $-0,003$ & 0,079 & $49 \%$ \\
\hline Transit Probabilities & $-0,228$ & $-0,004$ & 0,032 & $73 \%$ \\
\hline $\begin{array}{l}\text { Non-Motorized Travel } \\
\text { Mode Probabilities }\end{array}$ & 0,237 & 0,003 & 0,027 & $79 \%$
\end{tabular}

Upon analysis of cross-validation results, one can see that, despite the low correlation between observed and estimated values, there were also low values of the mean of the residuals and variance of errors. However, is to highlight that the percentage of correct estimation values is, with exception for Private Motorized Travel Mode Probabilities of Region 2, reasonably good. The travel mode probability was estimated for a $100 \times 100$ meters grid, for the referred region. Maps generated by Ordinary Kriging interpolation for the three travel modes are illustrated in Figure 9.

Results in the case of the probability of using private motorized travel mode, show that this travel mode is more likely to be used in the periphery of the region. Thus, the predisposition for car usage decreases considering the center proximity. Is to be highlighted that the main direction of 
this variogram $(\mathrm{N} 30 \mathrm{E})$ is clearly translated to the respective map. The kriging results for the transit and non-motorized travel mode also could be observed in the same figure. The predisposition to use other travel modes is opposing to the car usage. The tendency to use transit and non-motorized travel mode increases from the periphery to the center area.

The results of spatial interpolation are consistent with the reality of the region. Locations with higher probability of car/motorcycle use are exactly those corresponding to neighborhoods of higher income population. Conversely, the center of Region 2, which is the least probable to use the car, corresponds to low-income households.

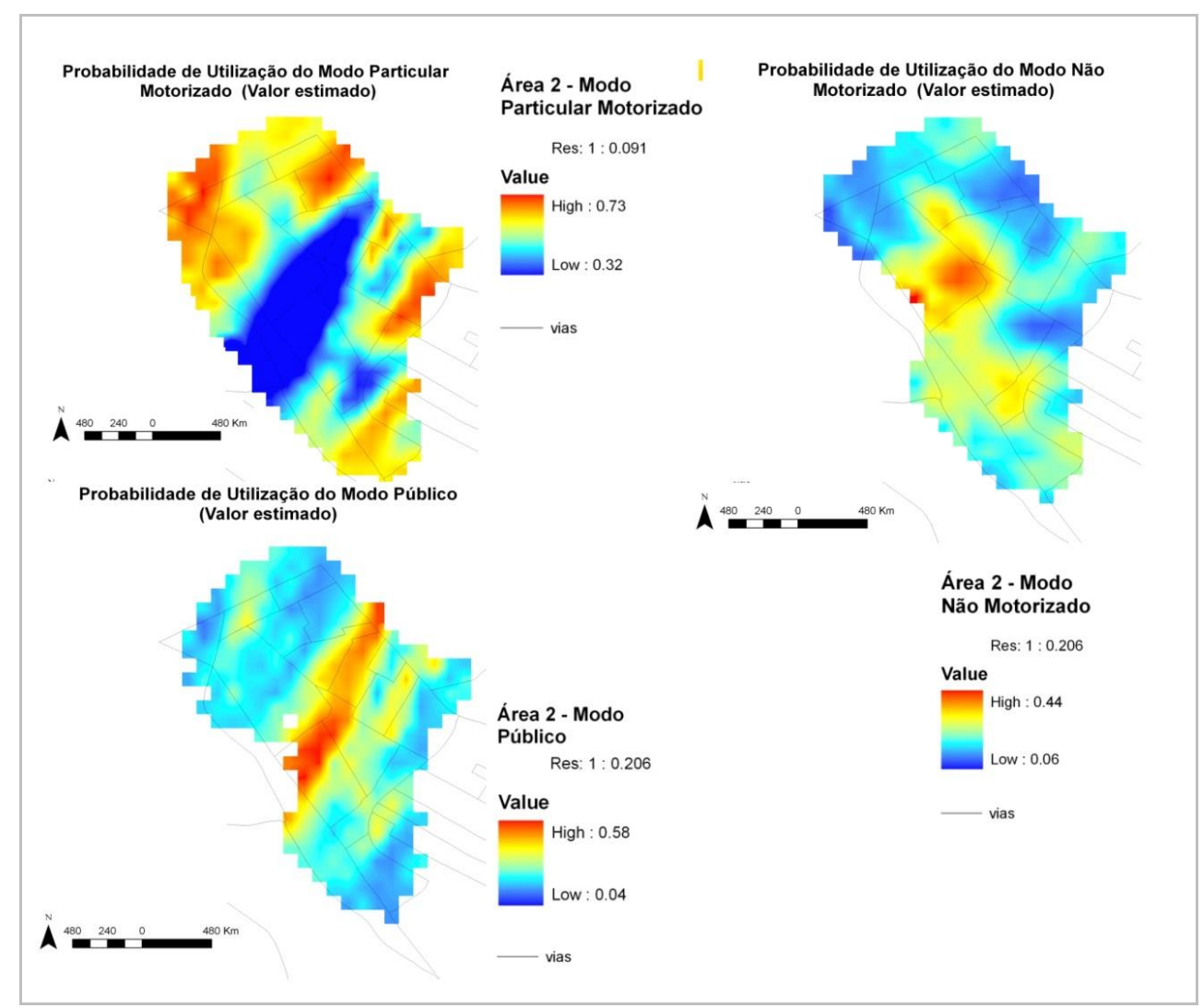

Figure 9: Interpolated values of mode choice's probabilities

\subsection{Conclusion}

The results obtained in this study allowed determining the probabilities of mode choice in household locations where choices are unobserved through this procedure (sequential application of Decision Tree analysis and Ordinary Kriging).

Through the application of DT, relationships between socioeconomic and transportation system variables and mode choice were found as expected, and found in literature (Bhat, 1997; Pas, 1984). The eleven terminal nodes, found in this work, synthesize groups of individuals susceptible to use a particular travel mode, considering socioeconomic and transportation system characteristics, selected by the data partition algorithm.

The resulting maps, obtained from Ordinary Kriging, allowed determining that there is a trend in the use of private motorized travel mode, which increases from the center to periphery. While, opposite trend was observed for the other travel modes in the same area. Cross-validation showed good results considering mean of residuals and variance of errors. Besides, a percentage of correct responses over 70\%, in case of non-motorized travel mode and transit, were achieved. 
An important aspect to be taken into consideration is that the regionalized variables are unnatural (not directly measured), were produced by a nonparametric model, the DT model. Moreover, the process developed in this study probably suffers from the influence of different errors from this type of data and the use of sequential estimation models (spatial and non-spatial).

Nevertheless, the innovative characteristic of this study should be taken into account. The twostep method presented is based in unusual techniques in the analysis of mode choice. However, the results show the success in this combination, which allowed a preliminary assessment of spatial particularities of the study area, and, it also emphasized the necessity of robust/solid information basis, special when dealing with questionnaires.

\section{ACKNOWLEDGEMENTS}

This work was supported by the Conselho Nacional de Desenvolvimento Científico e Tecnológico (CNPQ) and Fundação de Amparo à Pesquisa do estado de São Paulo (FAPESP).

\section{BIBLIOGRAPHICAL REFERENCES}

Ahern, Aoife A. and Nigel Tapley. "The use of stated preference techniques to model modal choices on interurban trips In Ireland". Transportation Research Part A: Policy and Practice 42 (2008): 15-27.

Bhat, Chandra and Huimin Zhao. "The spatial analysis of activity stop generation". Transportation Research Part B 36 (2002): 557-575.

Bhat, Chandra R "Work travel mode choice and number of non-work commute stops". Transportation Research Part B: Methodological 31 (1997): 41-54.

Breiman, Leo., Jerome Friedman., Charles J. Olshen, and R.A. Stone. Classification and Regression Trees. Wadsworth International Group, California, 1984.

Cervero, Robert. and Carolyn Radisch. "Pedestrian versus automobile oriented neighborhoods". Transport Policy 3 (1996): 127-141.

Ciuffo, Biagio and Vincenzo Punzo "Kriging meta-modelling in the verification of traffic microsimulation calibration procedure. Optimization algorithms and goodness of fit measures". Paper presented at the TRB 90th Annual Meeting Compendium of Papers, 2011.

Goovaerts, Pierre. "Geostatistics for Natural Resources Evaluation”. Applied Geostatistics Series (1997). New York, 483. Oxford: Oxford UniversityPress,

Goovaerts, Pierre. Using elevation to aid geostatistical mapping of rainfall erosivity. Catena 34 (1999): 227-242.

IBGE - Brazilian Institute of Geography and Statistics. Census Brazilian population in 2010. Accessed on August 20, 2012. In Portuguese. http://www.ibge.gov.br.

Isaaks, Edward H.. and R. Mohan Srvastava. An introduction to applied Geostatistics. Oxford University Press. 1989.

Ji, Jue and Xiaolu Gao. "Analysis of people's satisfaction with public transportation in Beijing". Habitat International 34 (2010): 464-470. 
Kitamura, Ryuichi; Patricia L Mokhtarian and Laura Laidet. "A micro-analysis of land use and travel in five neighborhoods in the San Francisco Bay Area”. Transportation 24 (1997): 125158.

Matheron, Georges. "The theory of regionalized variables and its applications". Technical Report 5 (1971), Paris School of Mines. Cah. Cent. Morphol. Math., Fontainbleau..

Matheron, Georges "Principles of geostatistics". Economy Geology 58 (1963):1246-1266.

Mazzella, Alessandro, Claudia Piras and Francesco Pinna. "Use of Kriging Technique to Study Roundabout Performance". Transportation Research Record: Journal of the Transportation Research Board 2241 (2011).

Miura, Hidetoshi. A study of travel time prediction using universal kriging. TOP, 18(1): 257$270,2010$.

Ortúzar, Juan de Dios and Luis G. Willumsen. Modelling Transport. Wiley, $4^{\text {th }}$ Edition, 2011.

Páez, Antonio, Fernando A López., Manuel Ruiz and Catherine Morency, C. "Development of an indicator to assess the spatial fit of discrete choice models". Transportation Research Part B 56 (2013): 217-233.

Pas, E.I. "The effect of selected sociodemographic characteristics on daily travel-activity behavior". Environment and Planning A. 16A (1984): 571-581.

Peer, Stefanie, Jasper Knockaert, Koster, Paul, Yin-Yen Tseng and Erik T Verhoef. "Door-todoor travel times in RP departure time choice models: An approximation method using GPS data". Transportation Research Part B 58 (2013): 134-150.

Pitombo, Cira Souza, Antonio Jorge Sousa, Markin Birkin and José Alberto Quintanilha. "Comparing different spatial data analysis to forecast trip generation". In: World Conference on Transport Research Society, 2010, Lisbon. Proceedings of the 12th WCTR. Lisboa. 2010.

Pitombo, Cira Souza, Eiji Kawamoto and Antonio Jorge Sousa. "An exploratory analysis of relationships between socioeconomic, land use, activity participation variables and travel patterns". Transport Policy 18 (2011): 347-357.

Pitombo, Cira Souza., Ana Rita Salgueiro, Aline S. G. Costa and Cassiano A. Isler. "A Two-step method for mode choice estimation with socioeconomic and spatial information". Spatial Statistics 11(2015): 45-64.

Rodrigues Da Silva, Antonio N. "Preparation of a travel database for assistance of development researches in transportation planning area". FAPESP Report, Case No. 04/15843-4. School of Engineering of São Carlos, University of São Paulo, Brazil. In Portuguese. 2008.

Sen, Ashish., Siim Sööt and Efi Pagitsas "The logit modal split model: Some theoretical considerations". Transportation Research Part A 12 (1978): 321-324.

Shmueli, Deborah, Ilan Salomon and Daniel Shefer "Neural network analysis of travel behavior: Evaluating tools for prediction". Transportation Research Part C: Emerging Technologies 4 (1996): 151-166.

Wackernagel, Hans. Multivariate Geostatistics: An introduction with applications. Springer, Third Edition. 2010.

Wang, Young, Dafang Zhuang and Haode Liu. "Spatial Distribution of Floating Car Speed". Journal of Transportation Systems Engineering and Information Technology 12 (2012): 36-41. 
Xie, Chi., Jinyang Lu and Emily Parkany. "Work Travel Mode Choice Modeling with Data Mining: Decision Trees and Neural Networks". Transportation Research Record: Journal of the Transportation Research Board 1854 (2007): 50-61.

Zou, Haixiang, Yang Yue, Qingquan Li and Anthony G.O. Yeh. "An improved distance metric for the interpolation of link-based traffic data using kriging: a case study of a large-scale urban road network". International Journal of Geographical Information Science 26 (2012): 667-689, 2012.

(Recebido em Novembro de 2014. Aceito em Março de 2015). 


\title{
USO DE RECEPTORES GPS DE 100 HZ NA DETECÇÃO DE DEFLEXÕES VERTICAIS MILIMÉTRICAS DE PONTES DE CONCRETO DE PEQUENO PORTE
}

\author{
The use of GPS at a rate of $100 \mathrm{HZ}$ to detect millimetric vertical deflections of \\ small sized concrete bridges
}

\author{
ANA PAULA CAMARGO LAROCCA ${ }^{1}$ \\ JOÃO OLYMPIO DE ARAÚJO NETO ${ }^{2}$ \\ JORGE LUIZ ALVES TRABANCO ${ }^{3}$ \\ AUGUSTO CÉSAR BARROS BARBOSA ${ }^{4}$ \\ ANDRÉ LUIZ BARBOSA NUNES DA CUNHA ${ }^{1}$ \\ RICARDO ERNESTO SCHAAL ${ }^{5}$

\begin{abstract}
${ }^{1}$ Universidade de São Paulo, Escola de Engenharia de São Carlos (EESC-USP) - São Carlos, SP, Brasil larocca.ana@usp.br, acunha@sc.usp.br

${ }^{2}$ Instituto Federal de Educação, Ciência e Tecnologia (IFSULDEMINAS) - Inconfidentes, MG, Brasil joao.olympio@ifsuldeminas.edu.br
\end{abstract}

\begin{abstract}
trabanco@fec.unicamp.br
${ }^{4}$ Universidade Estadual do Ceará, Centro de Ciências e Tecnologia (UECE-CCT) - Fortaleza, CE, Brasil barbosaiag@gmail.com
\end{abstract} \\ ${ }^{3}$ Universidade Estadual de Campinas, Faculdade de Engenharia Civil (UNICAMP) - Campinas, SP, Brasil - \\ ${ }^{5}$ Universidade de São Paulo, Escola Politécnica (EPUSP) - São Paulo, SP, Brasil - schaal@sc.usp.br
}

\section{Resumo:}

As últimas quatro décadas foram importantes para o desenvolvimento da malha rodoviária brasileira. O país recebeu incentivos financeiros para a sua expansão e diversas soluções estruturais para pontes e viadutos foram criadas. Em paralelo a este desenvolvimento, houve nos últimos anos um crescimento significativo dessas estruturas em estágio avançado de deterioração devido à ausência de programas de manutenção preventiva. Dessa maneira, este trabalho propõe o uso de receptores GPS num plano de monitoramento de curta duração para acompanhar o comportamento estrutural de uma ponte rodoviária curva de concreto armado já em serviço. E apresenta os primeiros resultados da pesquisa com a portadora L1 do sistema GPS e dados gravados com taxa de $100 \mathrm{~Hz}$, no monitoramento do vão central de ponte de concreto de pequeno porte situada sobre o Rio Jaguari, na cidade de Extrema, divisa entre os Estados de Minas Gerais e São Paulo. O desafio reside no fato de que estruturas como estas - pontes de concreto de pequeno e médio porte - respondem pela grande maioria das obras de arte da malha rodoviária brasileira e por serem estruturas rígidas, apresentam deflexões verticais pequenas, de até $5 \mathrm{~mm}$. O experimento foi realizado por meio de sessões de observações com receptores GPS sobre a ponte, no vão instrumentado por equipamentos convencionais para posterior confrontação de 
resultados entre os receptores GPS e os métodos clássicos de monitoramento. A ferramenta de filtragem Continuos Wavelet Transform (CWT) foi utilizada para analisar as frequências de resposta da ponte a partir dos resíduos da dupla diferença de fase da portadora L1. A análise do espectro de energia da CWT gerado a partir dos dados coletados com os receptores GPS indicou alta concentração de energia nas mesmas faixas de frequência - de resposta do tabuleiro da ponte - apontadas pela Modelagem por Elementos Finitos e pela prova de carga dinâmica.

Palavras-chave: Monitoramento; Ponte de Concreto; GPS; Filtragem de Sinais; Ondeleta de Morlet; Transformada Continua Wavelet.

\begin{abstract}
:
The last four decades were important for the Brazilian highway system. Financial investments were made so it could expand and many structural solutions for bridges and viaducts were developed. In parallel whit this development, there was a significant raise of pathologies in these structures, due to lack of maintenance procedures. Thus, this paper purposes the use of GPS to create a short-term monitoring plan in order to check the structural behavior of a curved highway concrete bridge in current use. And it present the first results of the research with the L1 GPS carrier frequency and recorded data at a rate of $100 \mathrm{~Hz}$, at the monitoring center span of small concrete bridge located on the Jaguari River, in the city of Extreme which borders Minas Gerais and São Paulo states. The challenge lies in the fact that such structures, small and medium-sized concrete bridges, account for the vast majority of art works of Brazilian highways and, as they are rigid structures, small present up to $5 \mathrm{~mm}$ vertical deflections. This experiment was carried out through observations sessions with GPS receivers over the bridge at the span instrumented by conventional structural equipment for further confrontation of results between GPS receivers and classic methods of monitoring. The Continuous Wavelet Transform (CWT) was used to analyze the frequency of the response of the bridge from the residues of double difference carrier phase L1.The analysis of the CWT energy spectrum generated from the data collected with GPS receivers indicated a high concentration of energy in the same frequency bands - of the bridge deck response identified by the Finite Element Modeling and the dynamic load test.
\end{abstract}

Keywords: Monitoring; Concrete Bridge; GPS; Filtering Signals; Morlet; Wavelet; Continuous Wavelet Transform.

\title{
1. INTRODUÇÃO
}

Houve nos últimos anos no Brasil um crescimento significativo de obras de arte especiais (OAEs) que apresentaram deterioração precoce causada pela ausência de programas de manutenção preventiva dessas estruturas. Embora o Brasil apresente órgãos regulamentadores que fornecem todo o procedimento para a inspeção e garantia da integridade de OAEs, em grande parte dos casos, as patologias são detectadas e as providências são tomadas apenas quando a deterioração da estrutura atinge um estado crítico ou quando oferece risco aos usuários. Um estudo feito pelo SINAENCO (Sindicato Nacional das Empresas de Arquitetura e Engenharia Consultiva), intitulado "Infra-Estrutura da Cidade: Prazo de Validade Vencido" mostra a necessidade de uma política permanente de manutenção de estruturas e administração dos recursos. Em relação às obras de arte especiais na cidade de São Paulo, o estudo mostra que há 240 pontes e viadutos em estado de deterioração, apresentando diversas patologias, e oferecendo risco aos usuários. Um dos principais fatores em destaque para a deterioração é atribuído ao investimento ínfimo em manutenção nos últimos anos, correspondente a 0,38\% do custo final das obras (Sinaenco, 2011; 
Andrade et al., 2013). A deterioração se reflete de diversas formas, como exposição de armaduras por falta de manutenção ou provocada por batidas de caminhões com excesso de altura, com consequente carbonatação; trincas, rachaduras com mais de $3 \mathrm{~cm}$ de espessura, eflorescência e lixiviação; desplacamento com pontos de infiltração; solapamento de taludes na região dos pilares; pilares com segregação da seção (http://www.sinaenco.com.br/default.asp). A consequência da falta de manutenção periódica nestas estruturas é a necessidade de intervenções mais onerosas e de maior porte.

Este trabalho apresenta os resultados parciais do monitoramento dinâmico de oscilações de um dos vãos do tabuleiro de uma ponte de concreto, com o uso do Sistema de Posicionamento Global (GPS) (Araújo Neto et al., 2014). Os ensaios apresentados a seguir fazem parte da continuidade do desenvolvimento de um método, iniciado em 2002 (Schaal e Larocca, 2002), denominado como Método dos Resíduos de Fase (MRF). Esta pesquisa busca melhorar o limiar de detecção do Global Positioning System (GPS), a partir do MRF, para que possa ser utilizado, também, no monitoramento dinâmico de pontes rígidas de pequeno porte. Até o momento, a aplicação do MRF era concentrada no monitoramento de oscilações de pontes suspensas e estaiadas de médio e grande porte (Larocca, 2004; Larocca et al., 2005; Larocca e Schaal, 2010; Larocca et al., 2011; Schaal et al., 2012; Larocca et al., 2013). Este método apresentava como grande desvantagem em 2004, a necessidade de programar o horário de coleta de dados em relação ao horário que apresentasse satélites com elevação maior de $80^{\circ}$, fato que foi mitigado com a introdução de maior número de satélites na constelação do sistema GPS.

Devido ao parque de obras de arte da malha rodoviária brasileira ser notadamente constituída por pontes de concreto de pequeno e médio porte, se fez necessário dar continuidade ao desenvolvimento do método. O propósito é que a facilidade e praticidade de utilização do GPS como instrumento de monitoramento de oscilações dinâmicas de pontes de concreto de pequeno e médio porte - possam ser largamente utilizadas pela engenharia, também no Brasil.

O Método dos Resíduos de Fase utiliza as observações GPS da portadora L1 transmitidos por apenas dois satélites da constelação GPS disponível no momento. Os dados dos sinais destes satélites são registrados pelos receptores GPS móvel, fora da estrutura. O método inclui a utilização de um oscilador eletromecânico com amplitude conhecida e especialmente projetado para instalar a antena GPS, o que permite a calibração do grau e frequência de oscilação presente na estrutura. Os resultados apresentados a seguir são oriundos de testes de campo iniciais realizados sobre uma ponte constituída por concreto armado localizada na Rodovia Fernão Dias - cidade de Extrema, sul de Minas Gerais.

\section{EMBASAMENTO TEÓRICO DO MÉTODO UTILIZADO}

O método usado neste artigo utiliza os dados do sistema de posicionamento GPS, os quais são transmitidos pela fase da portadora L1, com base no princípio da interferometria de Michelson (Kumar, 2004), já publicados em trabalhos anteriores, como em Schaal e Larocca, 2002; Larocca, 2004; Schaal e Larocca, 2009; Larocca et al., 2010; Larocca et al., 2013. Essa metodologia, resumidamente, consiste na aplicação do princípio da interferência sobre os sinais transmitidos pelos satélites da constelação GPS para realizar medições de distâncias através da alteração da fase provocada em um dos sinais. Neste caso, um receptor GPS é instalado sobre a estrutura a ser monitorada e o outro receptor que fica instalado numa base com coordenadas conhecidas; que é responsável pelas correções diferenciais. Na Figura 1 está ilustrada uma antena GPS fixada no vão central de uma ponte suspensa, sob ação de uma carga dinâmica - no caso, pela travessia de 
um caminhão. A frequência e a amplitude de oscilação do vão central podem ser determinadas com base na análise dos sinais GPS coletadas (Guo, 2005; Larocca e Schaal, 2005; Yi et al., 2010, 2013; Im et al., 2013).

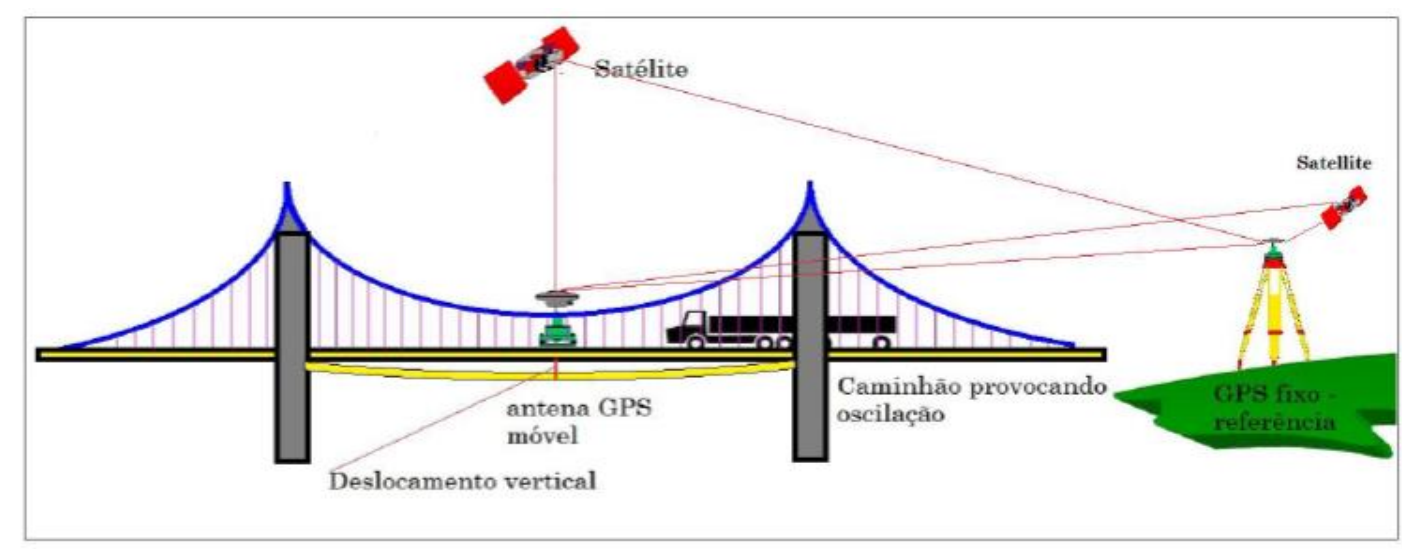

Figura 1: Antena GPS do receptor móvel sobre a ponte (Araújo Neto et al.,2013).

O método utilizado, baseado no princípio do interferômetro de fase, requer apenas a coleta de dados emitidos por dois satélites, com ângulo de fase maior que $80^{\circ}$ e não mais de uma constelação com mais de quatro satélite (Larocca, 2004). Assim, para se medir um deslocamento vertical, por exemplo, é necessário que um satélite esteja com elevação próxima a $90^{\circ}$ e outro com elevação próxima à linha do horizonte (Figura 2). No processamento da dupla diferença de fase, o satélite com baixa altitude é considerado como o satélite de referência, o qual permite obter o vetor dos resíduos do satélite com maior altitude, denominado aqui de 'satélite medidor'.

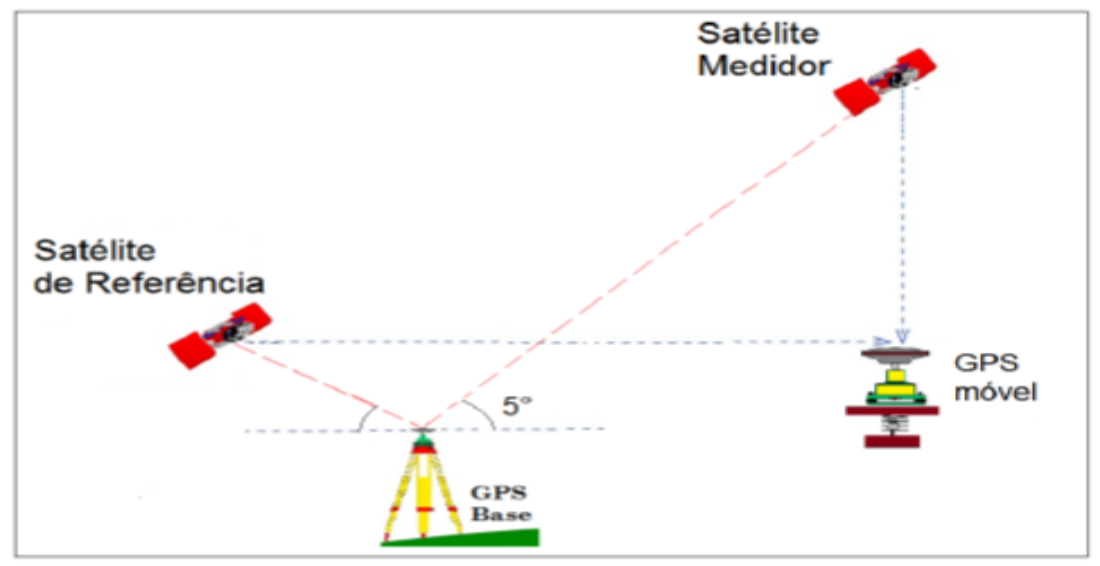

Figura 2: Satélite de referência e Satélite de medição (Araújo Neto et al., 2013).

\subsection{Oscilador Eletro-Mecânico}

Para calibrar a medição dos deslocamentos dinâmicos previamente desconhecidos na estrutura, foi desenvolvido em estudos anteriores um oscilador eletromecânico (OEM). O OEM aplica movimentos verticais controlados, em relação à amplitude e velocidade de deslocamento, na antena do receptor GPS que sofrerá os movimentos da estrutura. 
A Figura 3 apresenta uma antena GPSJAVAD (modelo - RegAnt_DD JAVAD), acoplada sobre o oscilador eletromecânico, o qual foi instalado sobre o pilar geodésico do IBGE, para a realização de experimentos preliminares com diferentes amplitudes e frequências.

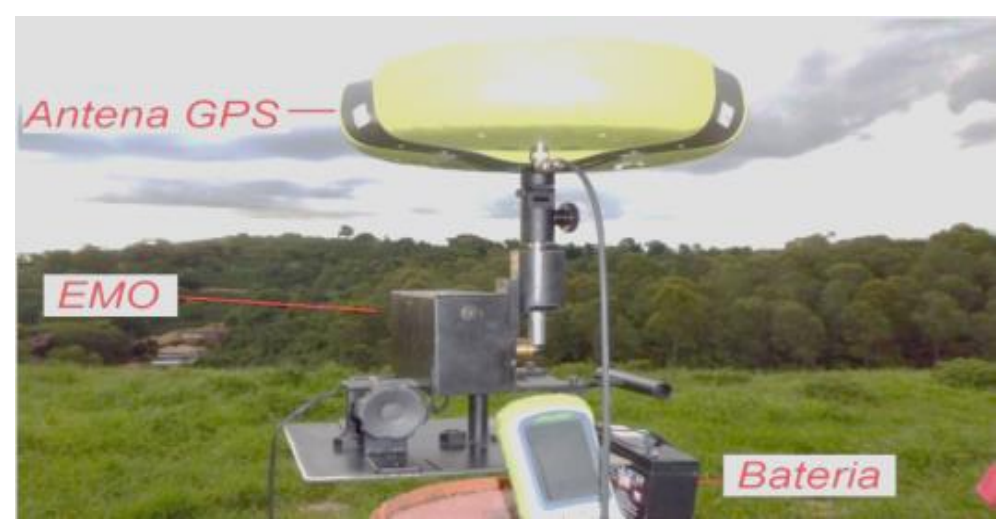

Figura 3: Detalhamento do Oscilador Eletromecânico com a antena JAVAD.

\subsection{Análise Espectral dos Dados}

A análise espectral dos resíduos resultantes do processamento GPS da dupla diferença de fase foi realizada utilizando-se a Continuous Wavelet Transform utilizando-se a Ondaleta-mãe (wavelet mãe) de Morlet (Daubechies, 1992; Morlet, 1983).

A transformada Wavelet permite avaliar analisar variações espectrais com diferentes resoluções em tempo-frequência-espaço. Esta técnica é também indicada em aplicações específicas, tais como os métodos para remoção de ruídos, pois esta se utiliza da fundamentação matemática extraída dos métodos clássicos desenvolvidos por Joseph Fourier (comumente conhecida como Transformada de Fourier). Isto significa que um sinal pode ser mapeado num plano tempo-escala, através de um escalograma (Goswami e Chan, 2011; Nguyen et al., 2010; Souza et al., 2009).

A CWT envolve um conjunto de operações "lineares" (convolução), as quais podem ser utilizadas no estudo de sinais não-estacionários para a extração de informação de variações de frequência e para detectar oscilações das estruturas localizadas na escala do tempo com sua localização espacial. Esta técnica tem sido amplamente utilizada em várias áreas de pesquisa e aplicações, por exemplo: em análise geofísica, hidrologia, dados climáticos, medicina, estudo do som, análise de dados de GPS, dentre outros estudos relacionados ao monitoramento de estruturas (Moschas et al., 2012; Beshr e Kaloop, 2013; Azarbad e Mosavi, 2013; Kaloop et al., 2013).

A escolha do uso da CWT com a Wavelet-mãe (Ondaleta-mãe) de Morlet foi estratégica, visto que os sinais analisados não são simultaneamente representados em tempo e em frequência pela Transformada clássica de Fourier, por serem não-estacionários, além de apresentarem energias bem distintas. Adicionalmente, estes sinais apresentam pequena amplitude pico a pico (de até5 $\mathrm{mm}$ ) em região de baixa frequência.

Para este fim, e como mencionado anteriormente, utilizou-se a Ondaleta-mãe de Morlet, aqual é definida da seguinte forma (Morlet, 1983):

$$
\Psi_{o}(\eta)=\pi^{-1 / 4} e^{i w_{o} \eta} e^{-1 / 2 \eta^{2}}
$$

onde: 
$w_{o}$ é a frequência de corte adimensional e

$\eta$ é o tempo adimensional.

Quando se utiliza este tipo de filtro para fins de extração de características de uma série temporal a waveletde Morlet é uma boa escolha, uma vez que proporciona excelente equilíbrio entre o tempo e a localização de frequência. A ideia proposta pela CWT é a sua aplicabilidade como um filtro passa-banda para as séries temporais.

A CWT de uma série temporal, $\{\mathrm{f}(\mathrm{t}), \mathrm{t}=1, \ldots, \mathrm{N}\}$, com intervalos de tempo distribuídos uniformemente por dt é definida como a convolução f(t) com a Ondaleta-mãe de Morlet, escalada e normalizada, conforme Equação (2) (Morettin, 2014):

$$
W_{j, k}(t)=\frac{1}{\sqrt{j}} \int_{t=1}^{N} f(t) \Psi_{o}\left(\frac{t-k}{j}\right) d t
$$

Sendo $\mathrm{Wj}, \mathrm{k}(\mathrm{t})$ a similaridade entre a função Ondaleta-mãe e a série temporal analisada $f(\mathrm{t})$, ou seja, quanto mais alto o valor de $\mathrm{Wj}, \mathrm{k}(\mathrm{t})$, maior a semelhança entre a função analisada e a função Ondaleta de Morlet, a qual modula o sinal analisado.

Para uma função ser considerada de Função Ondaleta-mãe, representada por $\Psi_{0}$, é necessário satisfazer as seguintes propriedades fundamentais:

$1^{a}$ Propriedade: A integral da função deve ser zero,

$$
\int_{-\infty}^{+\infty} \Psi_{0}(\mathrm{t}) \mathrm{dt}=0
$$

A Equação (3) assegura que a WF assuma uma forma de tipo onda. Esta condição é conhecida como uma condição de "admissibilidade". Isso assegura a existência da "Transformada Inversa em Ondaletas", na composição da série original.

$\mathbf{2}^{\mathbf{a}}$ Propriedade: Deve possuir energia unitária, i.e.,

$$
\int_{-\infty}^{+\infty}\left|\Psi_{0}(\mathrm{t})\right|^{2}=1
$$

A Equação (4) garante que a WF apresente suporte compacto, ou seja, um decaimento rápido de amplitude (do inglês e-foldingtime), o que garante que a Ondaleta-mãe apresente localização espacial, trata-se do grande diferencial em relação à Transformada Clássica de Fourier.

\section{PONTE DE CONCRETO SOBRE O RIO JAGUARI, MINAS GERAIS}

A ponte está situada numa porção da Rodovia Fernão Dias - BR 381, km 947, do acesso sentido sul da cidade de Extrema no sul de Minas Gerais, próximo à divisa com o Estado de São Paulo (Figura 4).

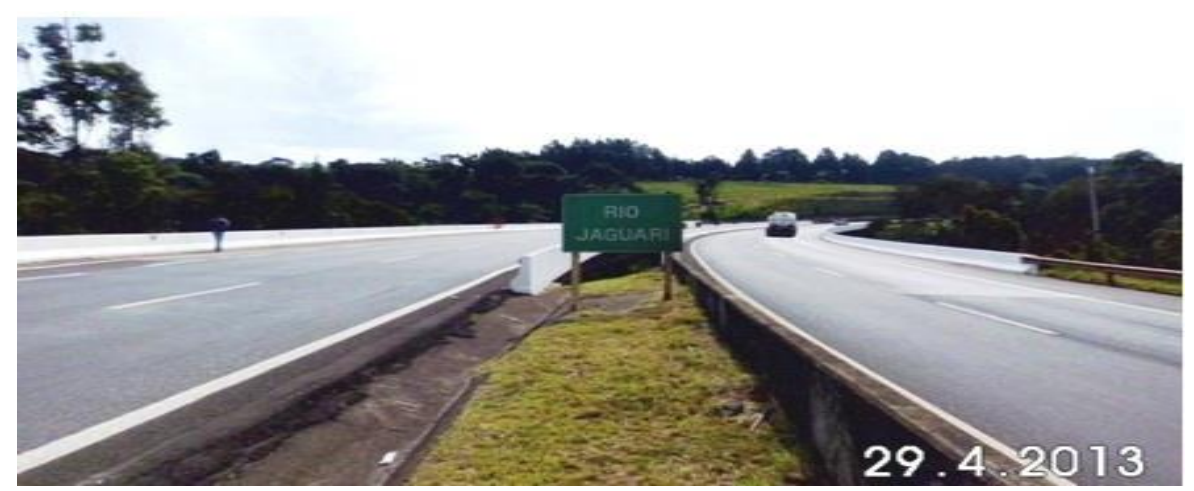

Figura 4: Ponte em estudo, sobre o rio Jaguari (Fonte: Andrade et al., 2013) 
Nesta fase do estudo optou-se pela ponte sul em função de sua característica e do tráfego no local. A largura total do tabuleiro é de 11,7 m, destes 10,9 m são divididos pelas duas faixas de tráfego e por uma faixa de acostamento, mais $0,4 \mathrm{~m}$ para todos os guarda-rodas do tipo New-Jersey constituídos em concreto armado (Andrade et al., 2013).

\subsection{Identificação dos Valores de Deflexão Vertical e Frequências esperados para o Tabuleiro da Ponte}

Os valores da amplitude da deflexão vertical e frequência de vibração do tabuleiro do vão de 30 metros foram obtidos por duas formas - através da Modelagem por Elementos Finitos e através de prova de carga dinâmica sobre o tabuleiro da ponte, respectivamente. Estes valores foram considerados como referência e serviram como elemento de confirmação sobre a detecção, ou não, através o uso de receptores GPS sob o MRF e CWT.

A modelagem numérica da ponte sobre o rio Jaguari foi realizada com base no Método dos Elementos Finitos (MEF) utilizados os softwares SAP2000 ${ }^{\circledR}$ V14 e Midas Fx+ for DIANA ${ }^{\circledR}$. Maiores detalhes dos modelos poderão ser conferidos em Andrade et al. (2013).O conteúdo espectral analisado permitiu a verificação das frequências mais excitadas, as quais correspondem às primeiras frequências no plano vertical longitudinal da ponte. Estas frequências permaneceram na faixa dos 5 a $10 \mathrm{~Hz}$. E desta forma, nortearam a indicação das frequências que deveriam também, ser identificadas com os receptores GPS, o MRF e a CTW.

A Figura 5 apresenta a identificação e localização dos acelerômetros utilizados na campanha de monitoramento realizada em 2011. Os dados da sessão S1 foram os comparados com os valores indicados pelo tratamento dos dados coletados comGPS.

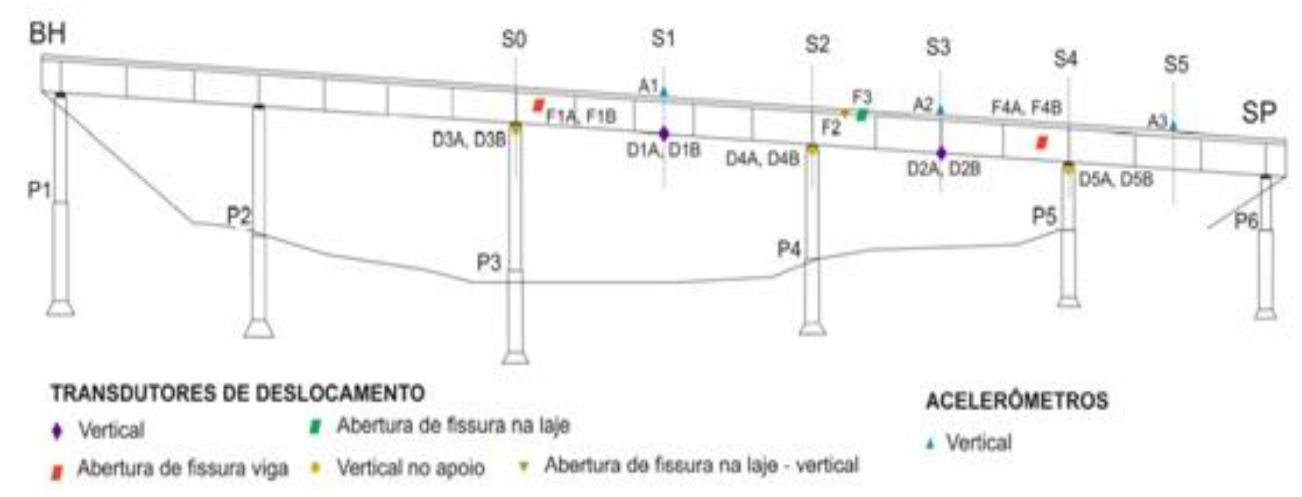

Figura 5: Layout da instrumentação da sessão S1 no vão de $30 \mathrm{~m}$ da ponte do rio Jaguari (Andrade et al., 2013)

A Tabela 1 apresenta o valor de deflexão vertical esperado com base nos resultados da análise linear, indicando deslocamento no meio do vão de 3,55 $\mathrm{mm}$. 
Tabela 1: Análise Linear: Comparativo deslocamento vertical Longarina LB (vãode $30 \mathrm{~m}$ ) (Andrade et al., 2013).

\begin{tabular}{c|c|c|c}
\hline \multirow{2}{*}{$\begin{array}{c}\text { Módulo de Elasticidade } \\
(\mathbf{G P a})\end{array}$} & \multicolumn{2}{|c|}{ Deslocamento (mm) } & \multirow{2}{*}{$\begin{array}{c}\text { Erro relativo } \\
(\%)\end{array}$} \\
\cline { 2 - 3 } & $\begin{array}{c}\text { Modelo Numérico } \\
(\mathbf{M N})\end{array}$ & $\begin{array}{c}\text { Veículo de Prova } \\
(\mathbf{V P})\end{array}$ & \\
\hline 24,68 & 2,933 & 3,55 & 17,37 \\
23,80 & 3,047 & & 14,16 \\
\hline
\end{tabular}

A etapa de realização de ensaios com carga dinâmica - monitoramento de curta duração com tráfego controlado - ocorreu no dia 10 de outubro de 2011. A realização desta etapa exigiu a interrupção do tráfego para a passagem do veículo com peso e velocidade conhecidos, denominado veículo de prova ou veículo teste.E através deste ensaio se teve a confirmação dos valores da frequência de vibração indicados pela MEF e esperados para o tabuleiro da ponte (ANTTRDT PROJETO 4 SGP/AFD, 2012; Andrade et al., 2013).

O veículo de prova constituiu de um caminhão de cinco eixos, sendo 2 eixos no cavalo mecânico e 3 eixos no semirreboque, conforme mostra a Figura 6. O peso total do veículo de prova carregado era de $44,3 \mathrm{t}$.

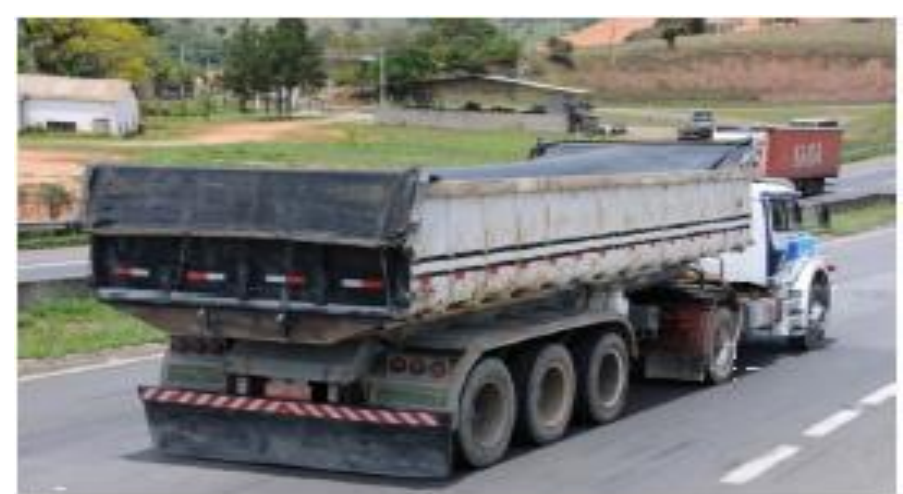

Figura 6: Veículo de prova de carga utilizado no teste na ponte (ANTTRDT PROJETO 4 SGP/AFD, 2012).

Para avaliar o conteúdo espectral dos registros temporais obtidos nos ensaios dinâmicos foram selecionados os intervalos de tempo em cada registro após a saída do veículo de prova da estrutura da ponte. A Figura 7, a seguir, ilustra a aceleração e as frequências naturais na direção vertical para o monitoramento do tráfego normal. 


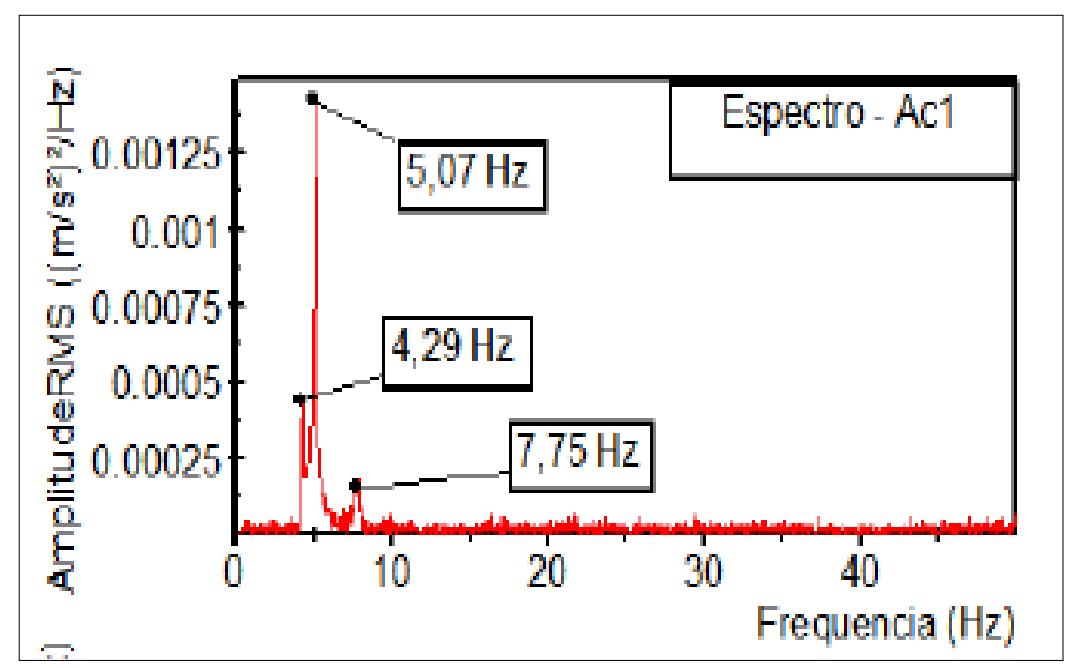

Figura 7: Espectro de aceleração (frequência) na direção vertical para o monitoramento do tráfego normal no dia 10/10/2011(Andrade et al., 2013).

\section{COLETA DE DADOS COM RECEPTOR GPS DE 100HZ}

As análises para testar o GPS como ferramenta para o monitoramento do vão central da ponte foram conduzidas em 4etapas: na primeira realizou-se o transporte de coordenadas para a região próxima da ponte; na segunda utilizou-se apenas o OEM com amplitude e frequência controlada, sobre um marco geodésico para ensaios sobre detecção de deflexões verticais de até $5 \mathrm{~mm}$; na terceira etapaforam feitas observações sobre aponte e a quarta, finalmente, constitui-se da análise de dados e comparação do valores obtidos com os indicados pela MEF e prova de carga dinâmica.

\subsection{Transportes de Coordenada para a Região mais Próxima da Ponte}

O procedimento para caracterizar o comportamento da ponte com o receptor GPS foi feito através do posicionamento relativo estático. Deste modo foi necessária a utilização de um marco geodésico com coordenadas ajustadas.

$\mathrm{Na}$ vizinhança da ponte não existia marco geodésico para a determinação relativa das coordenadas relativas da estação GPS sobre a ponte. Em função disso construiu-se um marco geodésico (Figura 8a, 8b e 9c) nas proximidades da ponte e que atendesse às normas e padrão de qualidade proposta pelo IBGE. 

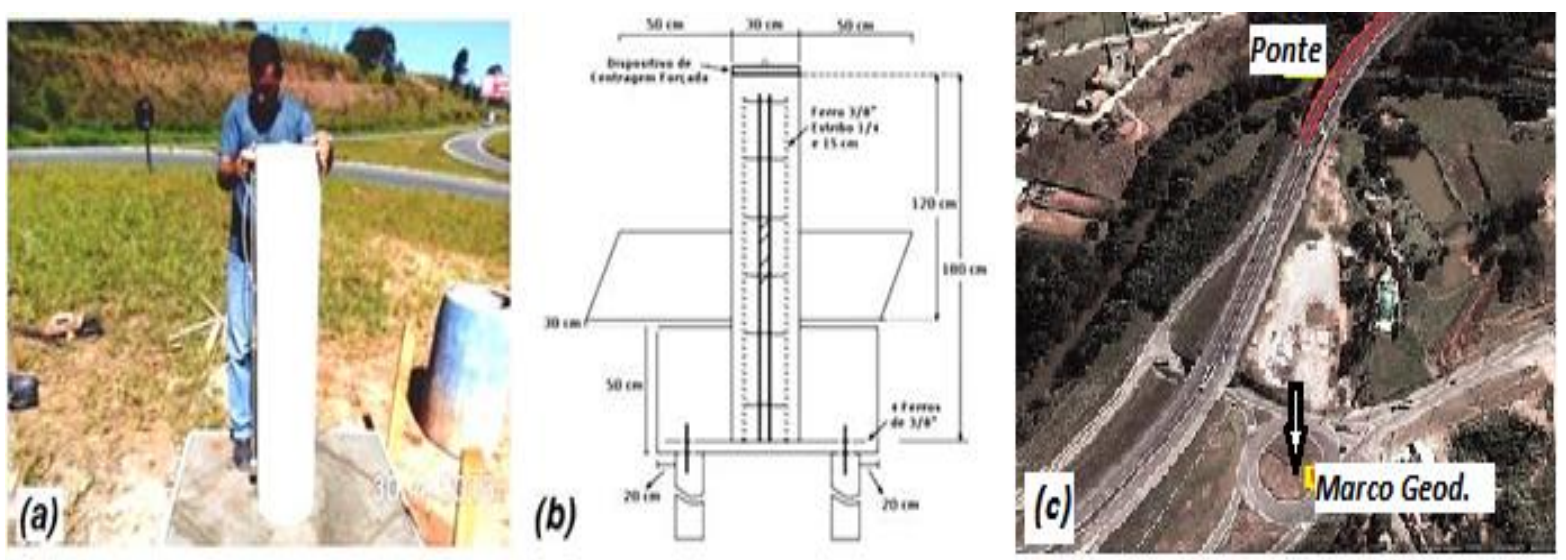

Figura 8: (a) Construção do marco geodésico, (b) Projeto para construção proposto pelo IBGE e (c) Mapa de situação da ponte e marco geodésico.

O local escolhido para a construção do marco geodésico foi o centro de uma rotatória nos limites da faixa de domínio da rodovia Fernão Dias, a 300 m de distância da ponte observada. A Figura 9 ilustra a localização em mapa do marco implantando.

Após a finalização da construção do marco, foi realizado o levantamento dos dados GPS (Figura 9) para o transporte das coordenadas. Este procedimento foi realizado em 3 dias diferentes, com 6 horas de rastreio, para que o mesmo fosse homologado pelo IBGE, com inclusão na Rede Geodésica Brasileira (RGB), em junho de 2013.

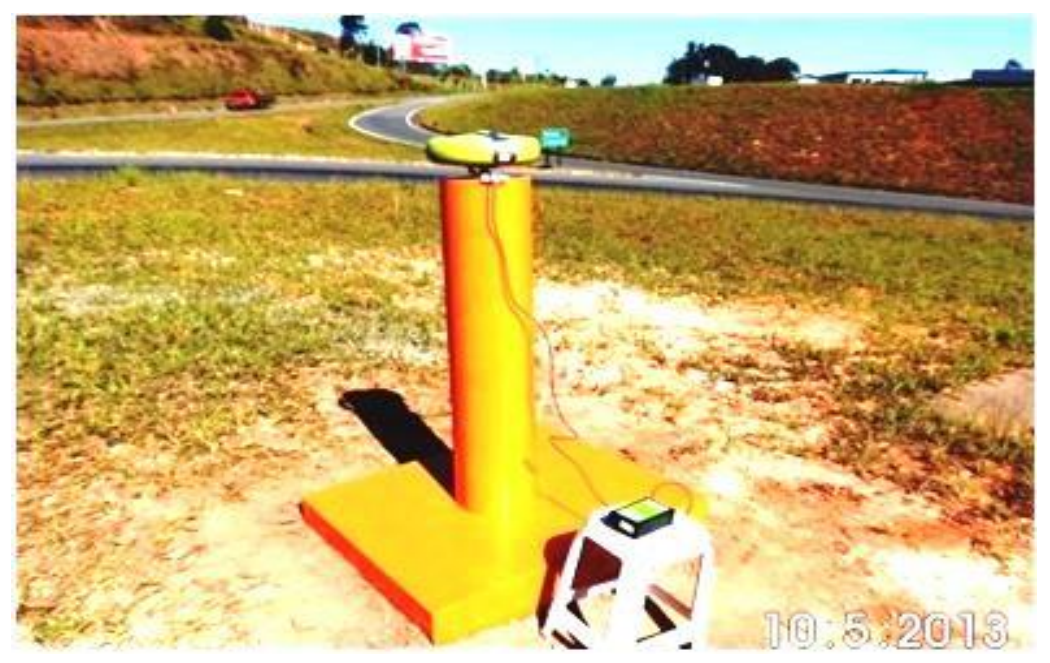

Figura 9: Coleta de dados no Pilar Geodésico para homologação pelo IBGE.

\subsection{Simulações com o OEM}

Antes da coleta dados na ponte foi necessário configurar e testar o dispositivo OEM e o receptor GPS com o objetivo de testar a capacidade do método em detectar, ou não, deslocamento com amplitude inferior a $5 \mathrm{~mm}$, valor este próximo do valor de deflexão esperado para o tabuleiro ponte. Para realizar as medições, a antena do receptor GPS foi instalada sobre o OEM e este sobre o marco geodésico do IBGE, localizado no Instituto Federal Sul de Minas Gerais - Campus Inconfidentes, Minas Gerais, conforme ilustração apresentada na Figura 10. 
O OEM foi usado para aplicar uma controlada movimentação vertical à antena GPS com frequência e amplitude de $0,4 \mathrm{~Hz}$ e $3,8 \mathrm{~mm}$, respectivamente. Para registrar as observações da constelação GPS, configuraram-se os receptores JAVAD SIGMA com taxa de gravação de 100 $\mathrm{Hz}$ para realizar medições durante3 minutos (Larocca et al., 2009).

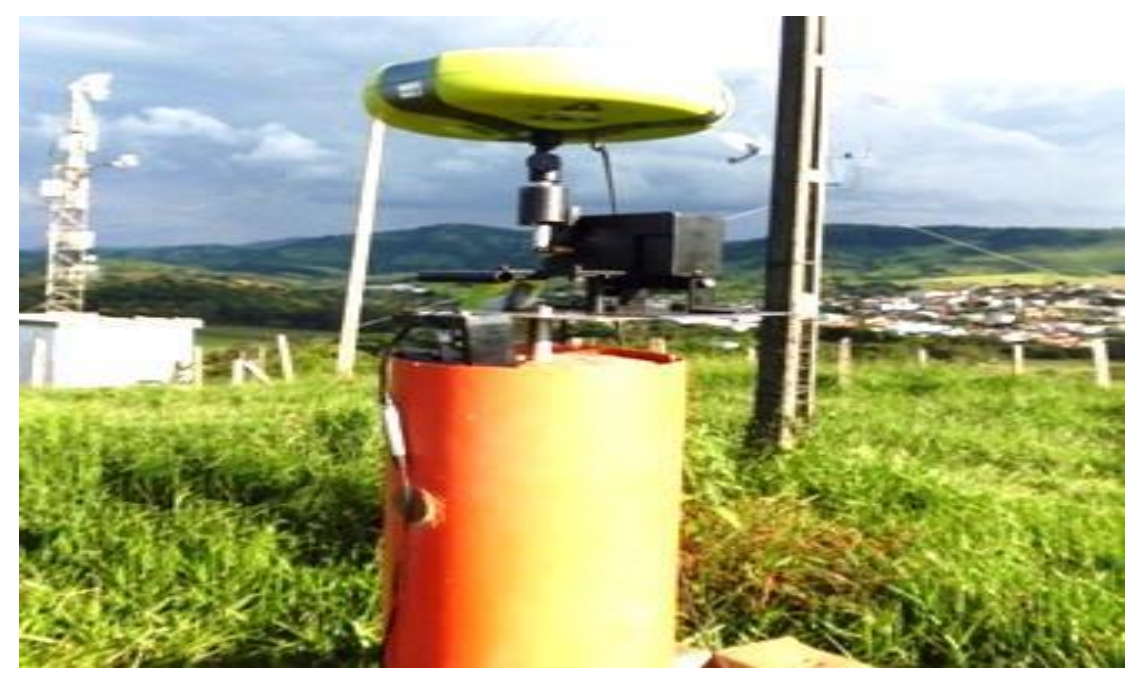

Figura 10: Antena GPS sobre o Oscilador Eletromecânico e Pilar do IBGE no IFSULDEMINAS - Campus Inconfidentes.

\subsection{Resultados das Simulações com o OEM}

De acordo com a Figura 12 (parte inferior) é possível observar o espectro de energia dos resíduos resultantes do processamento GPS da dupla diferença de fase, obtidos com a Ondaleta-mãe de Morlet. O modelo matemático utilizado na geração do espectro foi configurado para evidenciar fenômenos com 5\% de significância estatística, ou seja, 95\% de confiança - cujo nível de significância é limitado pelo contorno representado por uma linha - em preto, dentro do Cone de Influência (Barbosa e Blitzkow, 2008; Barbosa, 2012). O eixo das abscissas corresponde ao número de observações (a cada $0,01 \mathrm{~s}$ ), o eixo das ordenadas (à esquerda) representa o valor da frequência em Hertz e o eixo das ordenadas (à direita) representa a escala de intensidade de energia com que a frequência é apresentada na área do Cone de Influência. Adicionalmente, na Figura 12 (parte superior), refere-se aos resíduos brutos sem qualquer tipo de tratamento ou filtro, apenas normalizado por $\mathrm{N}-1$, onde $\mathrm{N}$ é o número de observações, oriundos da dupla diferença de fase da portadora L1, devido ao movimento periódico do EMO. Os demais gráficos de energia gerados pelo modelo matemático, no software MATLAB®,seguem o mesmo padrão de descrição.

Ainda, de acordo com a Figura 11, observa-se uma faixa contínua de energia significativa, detectada e representada pela cor vermelha ao longo de todo o período da série temporal, e que corresponde às oscilações programadas e aplicadas pelo EMO na antena móvel, em aproximadamente 0,4 Hz. Entre as observações 3000 e 4000 (Obs1), constata-se registros de energia em torno de $2 \mathrm{~Hz}$ - que devem estar relacionadas com alguma folga no mecanismo do OEM e será investigada em testes futuros. 

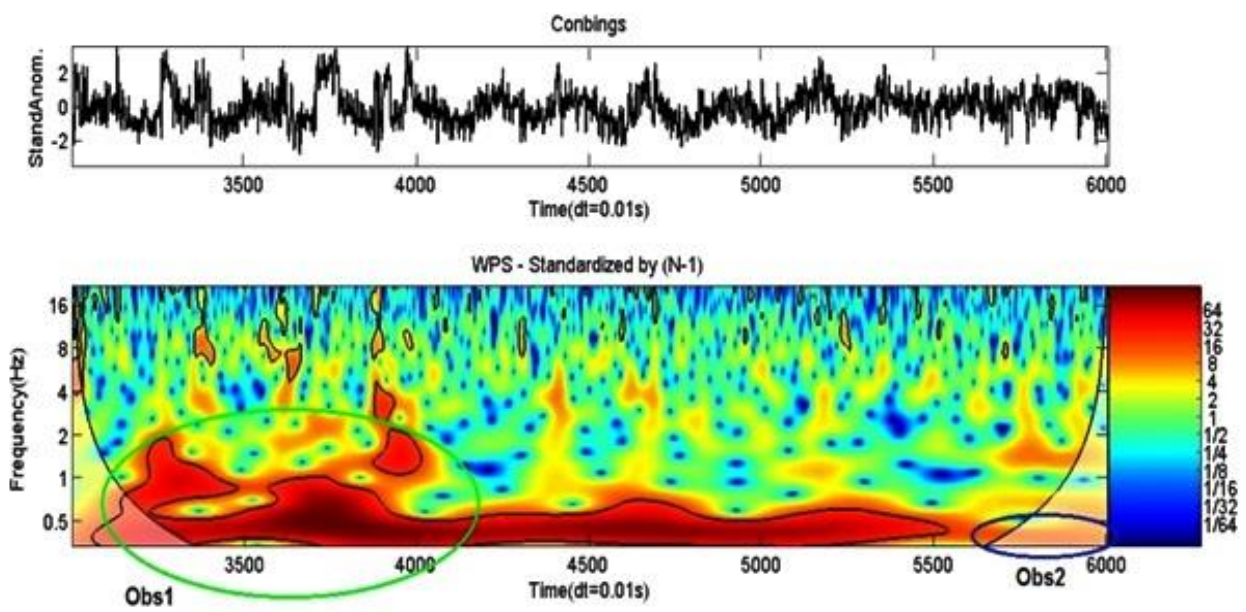

Figura 11: CWT dos resíduos da série temporal em observações entre 3500-5500, com nível de significância em $5 \%$ limitado pelo COI.

Assim, com a possibilidade de detecção de deflexões verticais com amplitude inferior a $5 \mathrm{~mm}$ confirmada, planejou-se a execução de testes na ponte.

Coleta de dados GPS sobrea ponte

Os primeiros ensaios na ponte foram realizados em época distinta às provas de cargas convencionais - a prova de carga foi realizada em 2011 e o monitoramento com receptores GPS em junho de 2013. Novos ensaios estão previstos para ocorrer simultaneamente com prova de carga, instrumentação com acelerômetro e receptores GPS.

\subsection{Layout da Instrumentação}

A instrumentação e coleta de dados GPS ocorreram com a ponte sendo solicitada pelo tráfego local da rodovia.Durante o período de coleta de dados, a ponte foi constantemente excitada pelo tráfego de veículos pesados de diferentes categorias de veículos que passavam pela rodovia. As Figuras 12a e 12b dispõem de uma imagem com detalhe da estrutura com vista inferior ao tabuleiro e sobre a ponte monitorada, com a antena GPS móvel instalada no guarda corpo através do pino fixado com epóxi. 

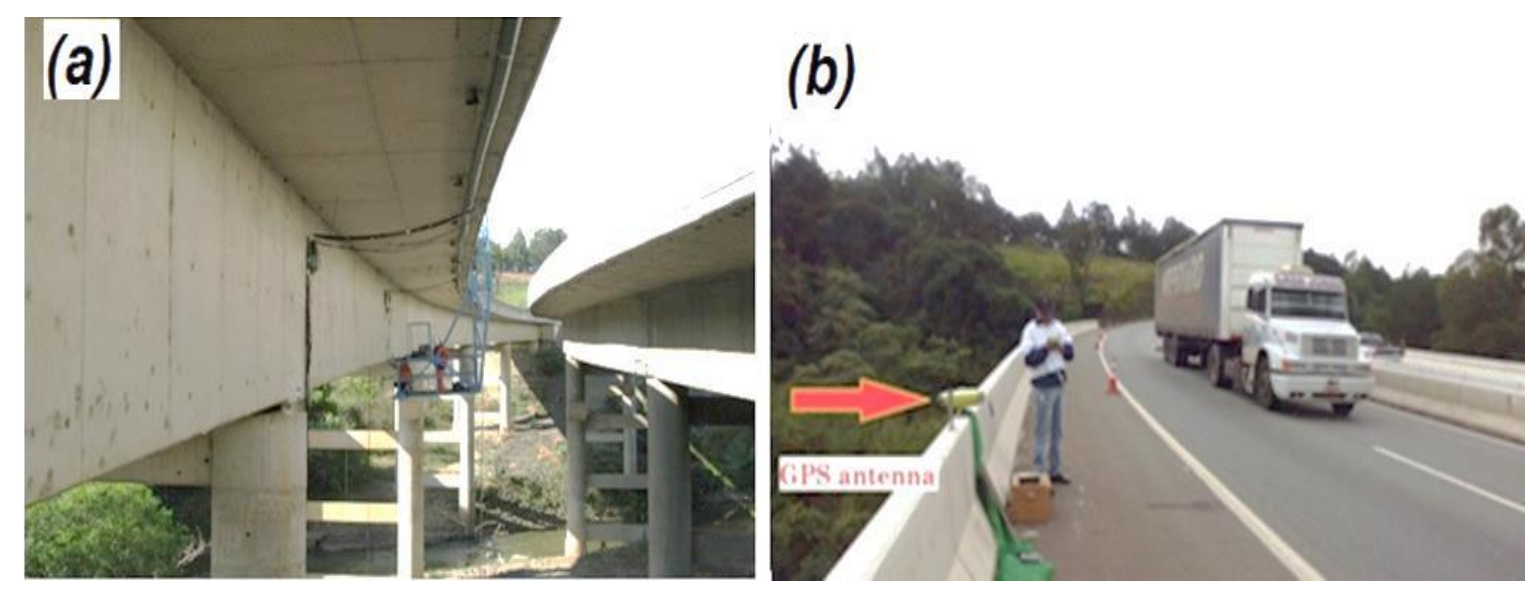

Figura 12: (a) vista inferior da ponte, (b) vista sobre a ponte no momento do rastreio com o receptor GPS.

A Figura 13 ilustra a localização do receptor GPS móvel (rover) sobre o centro do maior vão central da ponte. $\mathrm{O}$ oscilador eletromecânico foi ajustado para aplicar um deslocamento vertical de 3,8 mm e frequência de $0,40 \mathrm{~Hz}$. Houveram duas fases de medições sobre a ponte, uma com a utilização do EMO e a outra sem o dispositivo.

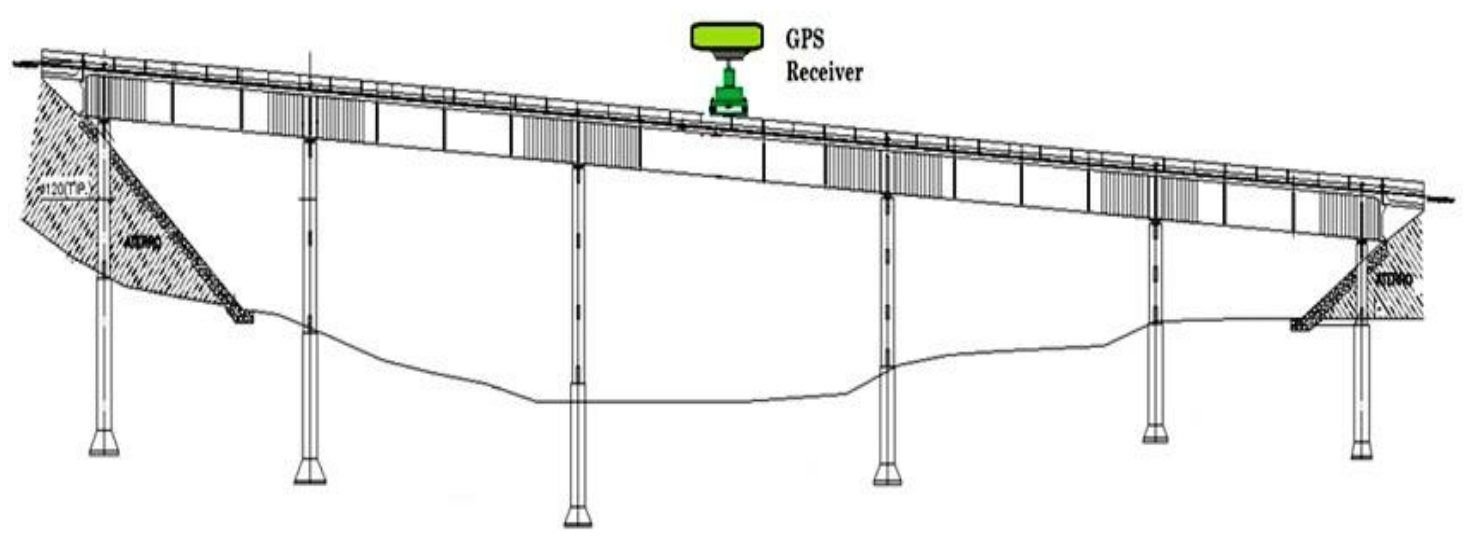

Figura 13: Esboço da ponte com o posicionamento do receptor GPS no vão de $30 \mathrm{~m}$.

\subsection{Coleta de Dados GPS}

Nessa fase do monitoramento, programou-se a coleta de dados GPS pelo denominado modo estático - quando os receptores permanecem estáticos sobre a referência (pilar) e sobre a estrutura (ponte). Assim, instalou-se uma antena GPS sobre a ponte, através de um pino de rosca universal de centragem forçada, fixada no centro do maior vão e borda da ponte, conforme Figura 13b. A outra antena GPS foi instalado sobre o marco geodésico na rotatória conforme mencionado anteriormente.

Para o processamento dos dados coletado sobre a ponte foi utilizado o software Justin JAVAD v. 2.107. Conforme a metodologia apresentada, utilizou-se como referência o satélite número 11,com elevação de $11^{\circ}$,e como satélite "medidor" optou-se pelo satélite 14 , com $87^{\circ}$ de elevação. Os posicionamentos instantâneos dos satélites utilizados na medição estão destacados no SKYPLOT (mapeamento da constelação GPS) na Figura 14. 


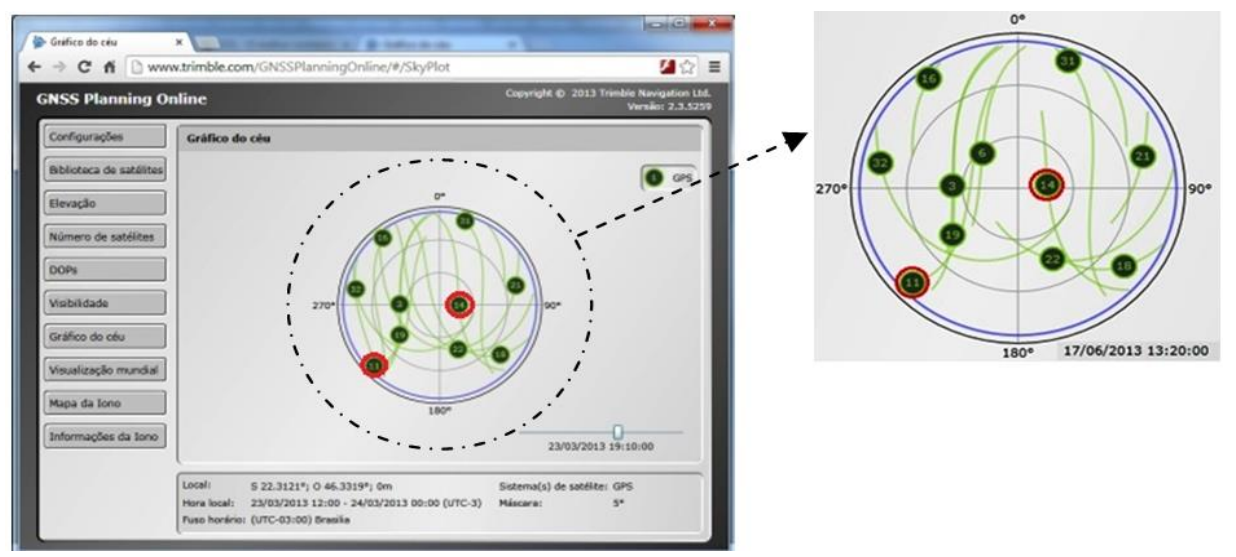

Figura 14: SKYPLOT da Constelação GPS no Experimento da Ponte em 17/06/2013.

\subsection{Análises dos Resultados}

A Figura 15 apresenta os primeiros 20 segundos de dados coletados com uma sequência de 2000 observações, espaçadas de $0,01 \mathrm{~s}$. O primeiro gráfico ilustra os resíduos da dupla diferença de fase processados pelos satélites de número 11 e 14. Pode-se observar alto nível de energia devido ao multicaminhamento do sinal GPS ao longo da faixa de frequência próximo ao valor de 0,05 Hz. Adicionalmente, pode-se observar alto nível de energia com valores de frequências na faixa de 4 a $8 \mathrm{~Hz}$, que corresponde aos valores de frequências indicados pela MEF (Figura 7) e com os valores obtidos da prova de carga realizada em 2011, indicados na Figura 8.

Desta forma, pode-se afirmar que foi possível identificar tanto as deflexões verticais do tabuleiro de 30 m de vão, bem como as frequências de resposta da estrutura à solicitação do tráfego local.

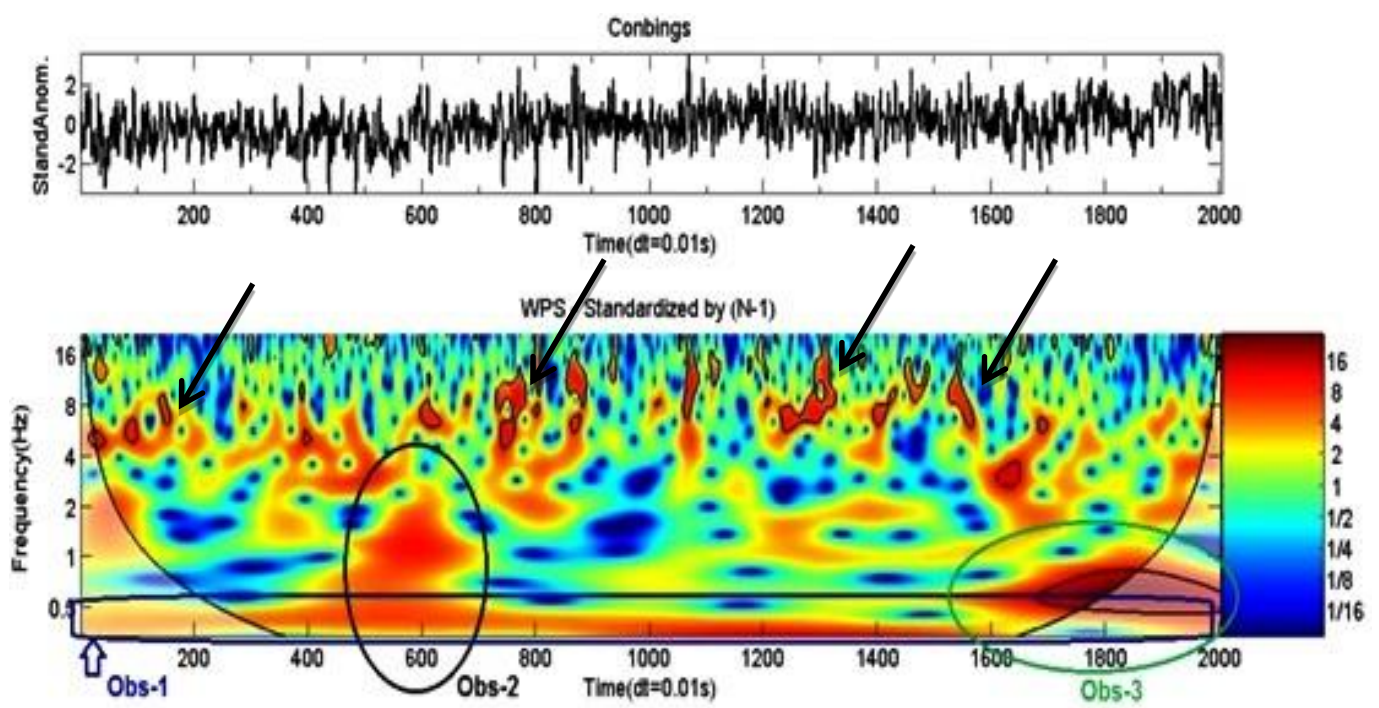

Figura 15: CWT dos resíduos da série temporal em observações entre 0-2000, com nível de significância em $5 \%$ limitado pelo COI.

Observa-se, ainda, alto nível de energia na região com períodos de 600 e de 1800 e indicados pelas elipses desenhadas sobre a figura 15. Neste estágio na pesquisa, fica a suposição de que se 
podem indicar a resposta do tabuleiro à passagem de veículos maiores como bitrens e ou rodotrens.

Na Figura 16, observam-se dados coletados nos 20 segundos seguintes (aos da Figura 16). Dentro do cone de influência (COI), observam-se novamente três regiões, definidas por A, B e C, com elevado nível de energia possivelmente devido à passagem de veículos mais pesados conforme mencionado anteriormente. Por outro lado, são identificadas as frequências na faixa de $4 \mathrm{a} 8 \mathrm{~Hz}$, que coincidem com os valores indicados pela MEF (Figura 7) e com os valores obtidos da prova de carga realizada em 2011, indicados na Figura 8.
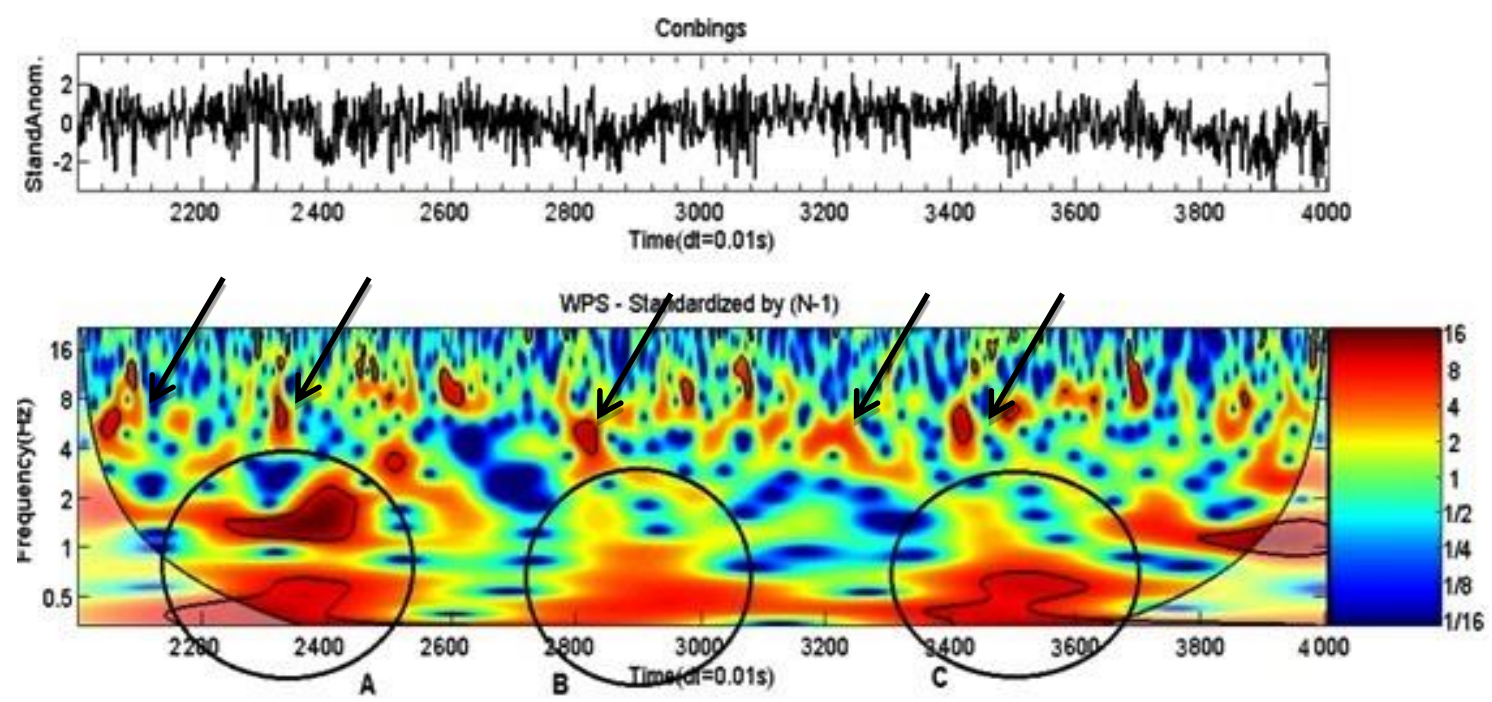

Figura 16: CWT dos resíduos da série temporal em observações entre 2000-4000, com nível de significância em $5 \%$ limitado pelo COI.

\section{ANÁLISES E CONCLUSÕES}

Os resultados obtidos indicaram a possibilidade de aplicação do método que envolve a combinação de Sistema de Posicionamento Global, Método dos Resíduos da Fase e CWT como uma ferramenta de monitoramento de deflexões milimétricas de tabuleiro de pontes de pequeno e médio porte. Os dados permitiram detectar as deflexões verticais com amplitude pico a pico de $3,5 \mathrm{~mm}$, com nível de confiança de $95 \%$. Estes valores foram confrontados com valores resultantes de métodos clássicos de monitoramento do comportamento dinâmico de estruturas como a Modelagem por Elementos Finitos e prova de carga dinâmica.

Os dados resultantes dos testes de calibração, com aplicação de deslocamento vertical com frequência e amplitude conhecidas pelo oscilador na antena GPS móvel apresentaram, na CWT, alta concentração de energia em torno de $0,4 \mathrm{~Hz}$, coincidindo como valor da frequência de oscilação configurada no oscilador.

Os testes realizados na ponte com os receptores GPS resultaram em valores de frequência e amplitude da deflexão vertical coincidentes com os valores provenientes da Modelagem por Elementos Finitos e prova de carga dinâmica. Frente ao exposto, conclui-se que a combinação proposta entre o uso de receptores GPS com alta taxa de dados $(100 \mathrm{~Hz})$ com técnicas de filtragem CWT permite detectar, com nível de confiança de $95 \%$ as ondas senoidais oriundas de deflexões verticais de tabuleiro de ponte de concreto com vão de $30 \mathrm{~m}$. 
As próximas etapas da pesquisa prevêem a análise do tráfego local e geração de uma biblioteca de resposta espectral de excitação do vão de $30 \mathrm{~m}$ aos diversos tipos de veículos trafegam pela ponte, através da análise por Wavelets e descrição do movimento do tabuleiro durante a travessia dos veículos. Também está previsto a realização de medidas concomitante com o registro do tráfego através de filmagem.

O GPS através do Método dos Resíduos de Fase apresenta, até o momento, forte indicação que pode ser utilizado como metodologia de instrumentação complementar não só em grandes pontes estaiadas e suspensas, mas também em pontes menores e de estrutura rígida, como as de concreto.

\section{AGRADECIMENTOS}

Os autores agradecem ao grupo de pesquisa do Prof. Dr.Túlio N. Bittencourt do Departamento de Engenharia de Estruturas e Fundações da Escola Politécnica da USP pela oportunidade de participação em medições na ponte sobre o Rio Jaguari; ao Laboratório de Topografia e Geodésia do Departamento de Engenharia de Transportes da Escola Politécnica da USP pelo empréstimo das antenas JAVAD chokering; ao IFSULDEMINAS pelo apoio com infraestrutura para construção de marco geodésico próximo da ponte; ao CNPq pela bolsa de produtividade PQ2 $\mathrm{n}^{\mathrm{o}}$. 304371/2013-0.

\section{REFERÊNCIAS}

Andrade, Rodolfo. G. M. Monitoramento de curta duração de uma ponte curva em concreto armado: um estudo de caso. 2012. 144 f. Dissertação (Mestrado) - Escola Politécnica da Universidade de São Paulo, São Paulo, 2012.

Andrade, Rodolfo. G. M.; Trautwein, Leandro. M and Bittencourt, Túlio N. Comparison and calibration of numerical models from monitoring data of a reinforced concrete highway bridge. IBRACON, São Paulo, v. 6, n.1, p. 121-138, 2013.

ANTTRDT PROJETO 4 SGP/AFD. Relatório Técnico do Projeto 4 SGP/AFD. ANTT. 2012.

Araujo Neto, João O.; Trabanco, J. L. A.; Larocca, A. P. C.; Barbosa, A. C. B. and Schaal, R. E. Monitoring the Vertical Deflections of the Small Concrete Bridge with the adapted Phase Residual Method using High Rate GPS Data. In:2 ${ }^{\text {nd }}$ Joint International Symposium on Deformation Monitoring (JISDM), Nottingham, Inglaterra. 2013.

Azarbad, Milad. R. and Mosavi, Mahmood. R. A. New Method to Mitigate Multipath Error in Single-Frequency GPS Receiver with Wavelet Transform. GPS Solutions, v. 18, n. 1, p. 189-198. 2013.

Barbosa, Augusto C. B. Oscilações Intrasazonais no Indo-Pacífico e na Zona de Convergência do Atlântico Sul: Estudo observacional e numérico. Tese (Doutorado), Departamento de Ciências Atmosféricas do Instituto de Astronomia, Geofísica e Ciências Atmosféricas, Universidade de São Paulo, 243 p. 2012.

Barbosa, Augusto C. B.; Blitzkow, D. Wavelet: History and Application. Lecture Notes. Institute of Astronomy, Geophysics and Atmospheric Sciences - University Sao Paulo - IAG/USP and POLI/USP.2008. 
Beshr, Ashraf and Kaloop, Mosbeh. Monitoring Bridge Deformation Using Auto-Correlation Adjustment Technique for Total Station Observations. Positioning, v. 4 n. 1, p. 1-7, 2013.

Çelebim, Muhterem. GPS in dynamic monitoring of long-period structures. Soil Dynamics and Earthquake Engineering, v.20, Issues 5-8, p. 477-483, 2000.

Daubechies, Ingrid.; Mallat, Stéphane and Willsky, Alan. S. Introduction to the special issue on Wavelet Transforms and Multiresolution Signal Analysis. IEEE Transactions on Information Theory, v. 38, n.2, p. 528-531, 1992.

Goswami, Jaideva. C. and Chan, Andrew. K. Fundamentals of wavelets. Microwave and Optical Engineering. Wiley Interscience, New Jersey, 2nd edition, 2011.

Guo, Jinjun, Xu, L., Dai, Lianjun., Mcdonald, Mike, Wu, Jianping, and Li, Yanying. Application of the Real-Time Kinematic Global Positioning System in Bridge Safety Monitoring. Journal of Bridge Engineering, v.10(2), p.163-168, 2005.

Im, Seok B.; Hurlebaus, Stefan and Kang, Young. Summary Review of GPS Technology for Structural Health Monitoring. J. Struct. Eng. v. 139, SPECIAL ISSUE: Real-World Applications for Structural Identification and Health Monitoring Methodologies, p.1653-1664, 2013.

Kaloop, Mosbeh, Elbeltagi, Emad, and Elnabwy, Mohamed Bridge Monitoring with Wavelet Principal Component and Spectrum Analysis Based on GPS Measurements: Case Study of the Mansoura Bridge in Egypt. J. Perform. Constr. Facil. (ASCE), SPECIAL ISSUE, 2013.

Kumar, Jeethendra P. K, and Jolly, Naresh Michelson Interferometer, Kamaljeeth Instrumentation \& Service Unit.India, v. 4, n.3, p. 180-192, 2004.

Larocca, Ana P. C. ; Schaal, Ricardo e.; Guimarães, Gabriel; Blitzkow, Denizar. Detection of Low Frequency Structures Oscillations on L1 GPS signal by Wavelets Analysis - Application on Monitoring Bridges. IUGG 2011 General Assembly, in Melbourne, Australia, 28 June - 7 July 2011, 2011.

Larocca, Ana P. C. and Schaal, Ricardo. Filtering techniques applied on raw carrier phase for GPS detecting small dynamic displacements. Boletim de Ciências Geodésica, Curitiba, Brasil, v. 16, n. 1, p.177-188, 2010.

Larocca, Ana P. C. e Schaal, Ricardo E. (2005). Millimeters in motion - dynamic response precisely measured. GPS World, Cleveland, v. 16, n. 1, p. 16-24, 2005.

Larocca, Ana P. C. O uso do GPS como instrumento de controle de deslocamentos dinâmicos de obras civis - aplicação na área de transportes. Tese de Doutorado. Departamento de Engenharia de Transportes. Escola de Engenharia de São Carlos, 2004.

Larocca, Ana P. C. O uso do GPS como instrumento de controle de deslocamentos dinâmicos de obras civis - aplicação na área de transportes. 2004. 203 f. Tese (Doutorado) - Escola de Engenharia de São Carlos, Universidade de São Paulo, São Carlos, 2004.

Larocca, Ana P. C.; Schaal, Ricardo e. and Barbosa Augusto C. B. Improving Detection of Low Frequency Vibrations using High Rate Data and Filtering Techniques in Time Series of GPS Baseline. In:22nd International Meeting of the Satellite Division of The Institute of Navigation, Savannah, GA, p. 1867-1875. September, 2009.

Larocca, Ana P. C.; Schaal, Ricardo E.; Santos, Marcelo C. L1 GPS as Tool for Monitoring the Dynamic Behavior of Large Bridges. Global Navigation Satellite Systems - From Stellar to Satellite Navigation. 1. ed. New York :In Tech. v. 1, p. 117-144, 2013.

Morettin, Pedro A. Ondas e Ondaletas: Da Análise de Fourier à Análise de Ondaletas de Séries Temporais. 2ed. São Paulo: Editora USP. 320 p., 2014. 
Morlet, Jean. Sampling Theory and Wave Propagation. NATO ASI Series, v. 1, p. 233-261 Springer, Berlin, 1983.

Moschas, Fannis; Avallone, Antonio; Moschonas, Nikolaos; Saltogianni, Vasso and Stiros, Stathis. Assessment of accuracy of PPP for very-hight-frequency dynamic, satellite positioning and earthquarke modeling. EGU General Assembly, 1 ${ }^{\text {nd }}$., 2012, Vienna, Austria, v. 1, p. 42-52, 2012.

Nguyen, Romain. Y.; Del-Castillo-Negrete, Diego; Schneider, Kai; Farge, Marie and Chen, Guangye. (2010) Wavelet-based density estimation for noise reduction in plasma simulations using particles. Journal of Computational Physics, v. 229, n. 8, p. 2821-2839, 2010.

Roberts, Gethin W.; Meng, Xiaolin and Dodson, Alan H. Integrating a Global Positioning System and Accelerometers to Monitor the Deflection of Bridges. Journal of Surveying Engineering (ASCE), v. 130, n. 2, p. 65-72, 2004.

Schaal, Ricardo E. and Larocca, Ana P. C. A Methodology for Monitoring Vertical Dynamic Sub-Centimeter Displacements with GPS. GPS Solutions, New York, v. 5, n.3, p. 15-18, 2002.

Schaal, Ricardo E.; Larocca, Ana P. C. and Guimarães, Gabriel N. Use of a single L1 GPS receiver for monitoring structures: first results of detection of millimetric dynamic oscillations. Journal of Surveying Engineering. v. 138(2), n. 2, p. 92-95, 2012.

SINAENCO (2011). Sindicato da Arquitetura e da Engenharia. Infra-Estrutura da Cidade de São Paulo: Prazo de Validade Vencido, São Paulo (http://www.sinaenco.com.br/default.asp), 2011.

Souza, Eniuce M., Monico, João F. G. e Pagamisse, Aylton. Redução do efeito do multicaminho de frequiências alta e baixa no posicionamento relativo cinemático utilizando wavelets: resultados preliminares. Boletim de Ciências Geodésicas (Impresso), v. 15, p. 142-156, 2009.

Torrence, Christopher and Compo, Gilbert P. A. Practical Guide to Wavelet Analysis. Bulletin of the American Meteorological Society, v. 79, p. 61-78, 1998.

Yi, Ting-Hua; Li, Hong-Nan and Gu, Ming. Experimental assessment of high-rate GPS receivers for deformation monitoring of bridge. Measurement, v. 46, n. 1, p. 420-432, 2013.

(Recebido em junho de 2014. Aceito em dezembro de 2014). 


\title{
ANÁLISE COMPARATIVA DOS RESULTADOS OBTIDOS PELOS MÉTODOS DE CALIBRAÇÃO DE CAMPO TRIDIMENSIONAL E BIDIMENSIONAL
}

\author{
Comparative analysis of results obtained by calibration with three-dimensional \\ and two-dimensional field methods
}

\author{
MARIANA BATISTA CAMPOS ${ }^{1}$ \\ ANTONIO MARIA GARCIA TOMMASELLI ${ }^{1}$ \\ MARCUS VINICIUS ANTUNES DE MORAES ${ }^{1}$ \\ JOSÉ MARCATO JUNIOR ${ }^{2}$ \\ ${ }^{1}$ Universidade Estadual Paulista Júlio de Mesquita Filho, FCT/UNESP, Programa de Pós Graduação \\ em Ciências Cartográficas
}

Email: marianaa.bcampos@gmail.com; tomaseli@fct.unesp.br; jirmarcato@gmail.com

2 Universidade Federal de Mato Grosso do Sul, FAENG,UFMS, Campo Grande.

Email :antunesdemoraes@gmail.com

\section{Resumo:}

Os recursos de automação têm facilitado a utilização da Fotogrametria Digital em várias aplicações. Um processo complexo e crítico em Fotogrametria, a calibração de câmaras, pode ser realizado automaticamente, existindo programas comerciais com essa capacidade. Dentre os métodos de calibração, destaca-se o método de calibração de campo, usando conjunto de pontos bidimensionais ou tridimensionais. Alguns programas comerciais utilizam um modelo de campo bidimensional (Placa 2D) que possibilita o reconhecimento automático de alvos, como por exemplo, o PhotoModeler. Entretanto, o campo de calibração tridimensional pode ser mais adequado para algumas aplicações, como por exemplo, para a modelagem tridimensional de objetos. No intuito de avaliar a influência nos parâmetros de orientação interior decorrente do uso de campos 2D ou 3D, foram realizadas 3 calibrações, utilizando 2 campos 2D e 1 campo 3D, as quais foram processadas em programas comercial e científico (PhotoModeler e Calibração com Múltiplas Câmaras). A forma de análise dos resultados consistiu em uma análise comparativa entre as calibrações, pelo estudo de influência dos Parâmetros de Orientação Interior (POI) na reconstrução de coordenadas de alvos sinalizados em um tripleto de imagens. Foram simuladas duas situações distintas (orientação exterior direta e indireta) e por fim, verificou-se o impacto dos POI nas coordenadas no plano e fora deste plano. A calibração com campo 3D, se comparada à calibração com o campo $2 \mathrm{D}$, permitiu redução de correlação entre a distância focal e a coordenada $\mathrm{Z}$ do centro perspectivo $\left(\mathrm{Z}_{0}\right)$. Verificou-se esse resultado na orientação direta e indireta. Observou-se, também, que o método de calibração 3D leva a melhores resultados no cálculo das coordenadas do tripleto de imagens para os alvos fora do plano.

Palavras-chave: Calibração de Câmaras; Método de Calibração de Campo; Correlação de Parâmetros; Photomodeler. 


\begin{abstract}
:
Automation resources have been used in Digital Photogrammetry in various applications. A complex and critical process in Photogrammetry, the camera calibration, can be performed automatically. Among the methods for camera calibration, field calibration using a set of twodimensional or three-dimensional points can be mentioned. Some commercial software uses a 2D plotted sheet, which allows the automatic recognition of targets, such as Photomodeler. However, the three-dimensional calibration field can be more suitable for certain applications, for example, three-dimensional object modeling. Thus, it is relevant to assess the effects of the interior orientation parameters, resulting from the use of these techniques, in particularly to correlation between parameters. For this purpose, three calibrations trials were performed using three different test fields (two 2D fields and one 3D field), processed in commercial and scientific software's (Photomodeler and Calibração com Múltiplas Câmaras). The results were analyzed by comparing calibrations, assessing the influence of the interior orientation parameters in the reconstruction of targets coordinate in an image triplet. Two different situations (direct and indirect exterior orientation) were simulated and it was verified the impact of the interior orientation parameters in the in-plane and out-of-plane coordinates. The calibration with 3D field, compared to 2D field, reduced the correlation between the focal length and the $\mathrm{Z}$ coordinate of the perspective center, showing better results for the correlation between parameters in both orientations (direct and indirect). It was also observed better results when using 3D calibration field for the calculation of out-of-plan targets coordinates.
\end{abstract}

Keywords: Camera Calibration; Field Calibration Method; Parameters Correlation; Photomodeler.

\title{
1. Introdução
}

O processo de calibração de câmaras é fundamental em Fotogrametria. A determinação dos parâmetros de orientação interior (POI) de cada câmara e sua confiabilidade, objetivo da calibração, possibilita a correção dos erros sistemáticos das medidas no espaço imagem, que afetam a precisão dos processos fotogramétricos posteriores.

Os POI ou parâmetros intrínsecos definem as características internas de uma câmara e permitem reconstruir analiticamente o feixe de raios formador da imagem. O conjunto de parâmetros mais empregado consiste em: distância focal, coordenadas do ponto principal, coeficientes de distorção radial simétrica, distorção descentrada e afinidade (Brown, 1971; Moniwa, 1972; Habib e Morgan, 2003).

A acurácia na determinação dos POI influencia nos produtos fotogramétricos como ortoimagens, Modelos Digitais de Terreno (MDT), modelos paramétricos de objetos, dentre outros (Galo et al., 2008).

Durante muitos anos as pesquisas relacionadas à calibração de câmaras foram voltadas para o aperfeiçoamento dos equipamentos, sendo que, em 1940, com o interesse militar durante a segunda guerra mundial, aumentaram os investimentos em equipamentos para calibração, como os Multicolimadores e Goniômetros, objetivando maior precisão e fácil manuseio, (Clarke e Fryer, 1998; Boland, 2000; Cramer, 2004; Merchant, 2012).

Grandes avanços nos modelos e métodos de calibração de câmaras ocorreram entre 1950 e 1970, destacando-se, além dos métodos de laboratório, os métodos de calibração de campo e o desenvolvimento do modelo de Conrady-Brown (Conrady, 1919; Eisenhart, 1963; Brown, 1966; 
Brown, 1971). Os diversos estudos relacionados à calibração de campo permitiram o desenvolvimento de variantes desse método, como por exemplo, o método de calibração plumbline (Brown, 1971), o método dos campos mistos (Merchant, 1979; Andrade e Olivas, 1981), autocalibração (Ebner, 1976; Brown, 1989; Fryer, 1996), câmaras convergentes (Kenefick et al, 1974), métodos de campo Tridimensional e Bidimensional (Merchant, 1979), dentre outros.

Com o desenvolvimento da Fotogrametria Digital e a automação de alguns processos, novas possibilidades de calibração facilitaram sua aplicação, como a identificação de alvos e medição das coordenadas no espaço imagem automaticamente.

Um avanço recente foi o desenvolvimento de programas comerciais, como por exemplo, o Photomodeler (Eos Systems inc, 2013), que, dentre outras funcionalidades, proporciona a calibração automática de câmaras a partir de alvos codificados pré-definidos. Este programa utiliza um padrão bidimensional para a calibração, que consiste de um conjunto de 4 alvos codificados e vários alvos circulares. Outros programas, inclusive em código aberto, também utilizam padrões bidimensionais (Heikkilä, 2000). Contudo, ressaltam-se as limitações desse tipo de configuração planar, sendo que os conjuntos tridimensionais produzem resultados mais robustos (Triggs, 1998; Zhang, 2000; Côrtes, 2010, Fraser, 2012).

Considerando esses avanços, a análise dos métodos de calibração em campo torna-se relevante diante da diversidade de câmaras e lentes, possibilitando verificar os benefícios das técnicas empregadas e suas limitações, principalmente no que concerne à correlação entre os parâmetros e a influência dos mesmos.

\section{Calibração de Câmaras}

A determinação dos parâmetros de orientação interior é realizada no processo de calibração (Andrade, 1998), possibilitando a análise do desempenho e da estabilidade da lente (Fryer, 1996).

Os métodos de campo permitem que todos os parâmetros sejam recuperados simultaneamente no processo de calibração, sendo requisito a superabundância de observações, o que torna possível um controle estatístico rigoroso no processo (Andrade, 1998).

Em geral, o processo de calibração de câmaras em campo pode ser realizado através de algumas etapas: (1) determinação de pontos com coordenadas conhecidas no espaço objeto (pontos de apoio), por meio de técnicas topográficas ou usando a tecnologia GNSS (Global Navigation Satellite System), por exemplo; (2) extração de coordenadas no espaço imagem, com acurácia da ordem do pixel ou subpixel, o que depende do tipo de alvo implantado no campo e do aplicativo usado para medição das coordenadas; (3) processamento da calibração com ajuste por feixes de raios e; (4) análise estatística para avaliara significância dos parâmetros, considerando a influencia de cada um deles no erro total modelado.

Os métodos de campo que utilizam conjunto de pontos 2D ou 3D, aliados ao método de câmaras convergentes, propiciam bons resultados com relação à redução de correlação entre os parâmetros de orientação interior e exterior. O método de câmaras convergentes consiste na tomada de fotografias convergentes, com no mínimo uma imagem, com rotação em torno do eixo $\mathrm{z}$, com kappa variando entre $0^{\circ},-90^{\circ}, 90^{\circ}$ e $180^{\circ}$, visando solucionar os problemas de dependência linear entre alguns parâmetros, o que dificulta a determinação dos efeitos individuais de cada um (Andrade, 1998). 
Apesar dos inúmeros estudos e métodos relacionados à calibração de câmaras, o desenvolvimento digital incentivou novas pesquisas no assunto, sendo um ponto de discussão na comunidade científica, enfatizando-se a importância da calibração para aumentar a exatidão dos processos (Mitishita e Olivas, 2001; Telles e Tommaselli, 2005; Bazan et al, 2009; Debiasi et al, 2012; Mitishita et al, 2012). Uma tendência é o desenvolvimento de programas que propiciam a calibração automática de câmaras, direcionada principalmente ao usuário não especialista. Dentre eles, destaca-se o Photomodeler, que, além da calibração automática, possibilita realizar medidas e a modelagem 3D de objetos, baseado nas técnicas de Fotogrametria Terrestre (Eos Systems inc, 2013).

Uma das aplicações mais antigas da Fotogrametria Terrestre é destinada ao registro arquitetônico, sendo que a calibração utilizando campo bidimensional é amplamente utilizada, principalmente pela facilidade de implantação dos modelos de campo 2D, com alvos de reconhecimento automático, disponibilizados por programas comerciais (Wang et al, 2008; Andrade e Schuler, 2011; Córdoba, 2012).

Além dos programas comerciais, existem os programas de calibração científicos, como por exemplo, o CMC (Calibração com Múltiplas Câmaras), desenvolvido pelo grupo de Pesquisa em Fotogrametria da Faculdade de Ciência e Tecnologia da Universidade Estadual Paulista (FCT/UNESP). O CMC foi desenvolvido em linguagem $\mathrm{C} / \mathrm{C}++$ e possui modelos de calibração para câmaras perspectivas convencionais e câmaras com lentes "olho de peixe", com estimação pelo Método dos Mínimos Quadrados, modelo combinado. Além disso, permite a calibração com injunções de estabilidade da orientação relativa (Ruy, 2008; Bazan et al., 2009).

Apesar das diferentes implementações, ambos os programas citados utilizam o modelo de correção de Conrady-Brown agregado às equações de colinearidade (Ruy, 2008; Bazan et al., 2009; Eos Systems inc, 2013).

\subsection{Modelo Funcional Básico}

O modelo de colinearidade baseia-se na condição geométrica de alinhamento entre um ponto no espaço objeto, seu respectivo ponto imagem e o centro perspectivo da câmara (Wolf e Dewitt, 2000).

Para realizar o processo de calibração, são adicionados às equações de colinearidade, os modelos paramétricos dos efeitos das distorções radial simétrica, descentrada e da afinidade. Assim as equações de colinearidade podem ser reescritas como nas Equações 1 e 2 (Fryer,1996):

$$
\begin{aligned}
& x=x_{0}-\Delta_{k_{x}}-\Delta_{p_{x}}-\Delta_{a_{x}}-f \cdot \frac{r_{11}\left(X-X_{0}\right)+r_{12}\left(Y-Y_{0}\right)+r_{13}\left(Z-Z_{0}\right)}{r_{31}\left(X-X_{0}\right)+r_{32}\left(Y-Y_{0}\right)+r_{33}\left(Z-Z_{0}\right)} \\
& y=y_{0}-\Delta_{k_{y}}-\Delta_{p_{y}}-\Delta_{a_{y}}-f \cdot \frac{r_{21}\left(X-X_{0}\right)+r_{22}\left(Y-Y_{0}\right)+r_{23}\left(Z-Z_{0}\right)}{r_{31}\left(X-X_{0}\right)+r_{32}\left(Y-Y_{0}\right)+r_{33}\left(Z-Z_{0}\right)}
\end{aligned}
$$

Em que:

$\mathrm{x}$, y são as coordenadas de um ponto no sistema de máquina, com origem no centro geométrico da imagem e paralelo ao sistema fotogramétrico;

$\mathrm{X}, \mathrm{Y}$ e Z são as coordenadas do ponto em um referencial cartesiano do espaço objeto;

$\mathrm{X}_{0}, \mathrm{Y}_{0}$ e $\mathrm{Z}_{0}$ são as coordenadas do centro perspectivo (CP) no referencial cartesiano do espaço objeto; 
f é a distância principal da câmara, ou constante da câmara; $\mathrm{r}_{\mathrm{ij}}$ são os elementos da matriz de rotação em função das rotações $\omega, \varphi$ e $\kappa$; $\mathrm{x}_{0}$ e $\mathrm{y}_{0}$ são as coordenadas do ponto principal;

$\Delta_{\mathrm{k}}$ são os deslocamentos causados pela distorção radial simétrica nas direções x e y; $\Delta_{\mathrm{p}}$ são os deslocamentos causados pela distorção descentrada nas direções x e y; $\Delta_{\mathrm{a}}$ são os deslocamentos causados pela afinidade entre as direções x e y.

\subsection{Modelo de Distorções de Conrady-Brown}

Conrady (1919) realizou um estudo sobre a distorção das lentes, sendo o primeiro a desenvolver um modelo para a distorção descentrada. A partir dos trabalhos de Conrady, Brown (1966) desenvolveu um modelo de correção, no qual as distorções são classificadas em distorção radial simétrica e distorção descentrada (Brown, 1971; Fryer, 1996), posteriormente denominado de Conrady-Brown.

A distorção radial simétrica é o deslocamento radial de um ponto na imagem de sua posição correta, ou seja, uma mudança no ângulo entre o raio de luz e o eixo óptico, causado pela refração sofrida pelo raio de luz ao atravessar o sistema óptico (Fryer, 1996; Wolf e Dewitt, 2000). As Equações 3 e 4 permitem o cálculo da distorção radial simétrica nas componentes x e y.

$$
\begin{aligned}
\delta_{x_{r}} & =\left(x-x_{0}\right)\left(k_{1} r^{2}+k_{2} r^{4}+k_{3} r^{6}\right) \\
\delta_{y_{r}} & =\left(y-y_{0}\right)\left(k_{1} r^{2}+k_{2} r^{4}+k_{3} r^{6}\right)
\end{aligned}
$$

Em que:

$\mathrm{x}$, y são as coordenadas de um ponto no sistema de máquina, paralelo ao fotogramétrico;

$\delta \mathrm{x}_{\mathrm{r}}$ é o efeito da distorção radial simétrica na componente $\mathrm{x}$.

$\delta y_{\mathrm{r}}$ é o efeito da distorção radial simétrica na componente $\mathrm{y}$.

r é o raio, calculado pela Equação 5 .

$\mathrm{k}_{1}, \mathrm{k}_{2}$ e $\mathrm{k}_{3}$ são os parâmetros da distorção radial simétrica.

$$
r=\sqrt{\left(x-x_{0}\right)^{2}+\left(y-y_{0}\right)^{2}}
$$

A distorção descentrada, por sua vez, é causada pela impossibilidade de alinhamento entre os eixos ópticos das lentes que compõem o sistema de lentes, causando um deslocamento na posição de um ponto na imagem (Andrade, 1998). Os efeitos dessa distorção podem ser quantificados pelas Equações 6 e 7.

$$
\begin{aligned}
& \delta_{x_{d}}=p_{1}\left(r^{2}+2\left(x-x_{0}\right)^{2}\right)+2 p_{2}\left(x-x_{0}\right)\left(y-y_{0}\right) \\
& \delta_{y_{d}}=p_{2}\left(r^{2}+2\left(y-y_{0}\right)^{2}\right)+2 p_{1}\left(x-x_{0}\right)\left(y-y_{0}\right)
\end{aligned}
$$

Em que:

$\delta x_{d}$ é o efeito da distorção descentrada na componente $\mathrm{x}$. $\delta y_{d}$ é o efeito da distorção descentrada na componente y. $p_{1}$ e $p_{2}$ são os parâmetros da distorção descentrada. 


\subsection{Modelos de afinidade}

A diferença de escala entre os eixos x e y do sistema de coordenadas e a não ortogonalidade entre os mesmos, pode ser modelada matematicamente através dos parâmetros de afinidade (Moniwa, 1972).

Existem diversos modelos que possibilitam esta parametrização dos efeitos, dentre eles destacam-se o modelo para câmaras analógicas não métricas, proposto por Moniwa (1972), também aplicado para câmaras digitais (Tommaselli e Tozzi, 1990), e o modelo desenvolvido por Habib e Morgan (2003), implementado no programa CMC (Equações 8 e 9).

$$
\begin{gathered}
\delta_{x_{a}}=A\left(x-x_{0}\right)+B\left(y-y_{0}\right) \\
\delta_{y_{a}}=A\left(y-y_{0}\right)
\end{gathered}
$$

Em que, $\delta x_{a}$ é o efeito da não ortogonalidade e da diferença de escala entre os eixos na componente x; $\delta y_{a}$ é o efeito da não ortogonalidade e da diferença de escala entre os eixos na componente y e $A, B$ são os parâmetros de afinidade.

\subsection{Coeficiente de Correlação}

Um dos problemas na calibração de câmaras é a correlação entre alguns parâmetros de orientação interior (POI) e orientação exterior (POE), principalmente quando são usados campos planos (2D). As principais correlações ocorrem entre os parâmetros: $x_{0}$ e $X_{0}, y_{0}$ e $Y_{0}, f$ e $Z_{0}$, mas ocorrem também entre, $x_{0}$ e $\varphi$, e $y_{0}$ e $\omega$ (Andrade, 1998).

São várias as estratégias para reduzir a correlação entre os parâmetros, como por exemplo, os métodos de câmaras convergentes e campos mistos, a aplicação de injunções nos POE, dentre outros (Merchant, 1979; Andrade e Olivas, 1981; Andrade, 1998). Esta correlação pode ser quantificada através da matriz dos coeficientes de correlação. Os elementos da matriz dos coeficientes de correlação podem ser calculados pela Equação 10, a partir da matriz de covariância obtida no ajustamento pelo método dos mínimos quadrados (Galo et al, 2008).

$$
\rho_{i j}=\frac{\sigma_{i j}}{\sigma_{i} \sigma_{j}}
$$

Onde, $\sigma_{i}$ e $\sigma_{j}$ correspondem, respectivamente, aos desvios-padrão dos parâmetros i e j e $\sigma_{i j}$ é a covariância entre os parâmetros i ej. 


\section{Campos de Calibração: Tridimensional e Bidimensional}

Para os estudos experimentais apresentados neste trabalho foram utilizados3 campos de calibração, sendo um campo tridimensional e dois campos bidimensionais.

O campo de calibração 3D com alvos codificados foi instalado pelo grupo de pesquisa em Fotogrametria da FCT-UNESP, em 2013, no terraço do prédio da central de laboratórios do Departamento de Cartografia. É composto por 139 alvos (quadrados) codificados internamente no padrão ArUco (Silva et al., 2014; Aruco, 2012; Tommaselli, et al, 2013).Cada alvo propicia 4 medidas nos vértices do quadrado, numerados de 0 à 3 (Figura 1.a).

O processo de localização e identificação automática destes alvos é realizado no programa Localizador de alvos, que utiliza rotinas da biblioteca OpenCV (Silva et al., 2014), também desenvolvido pelo grupo de pesquisa e fornece coordenadas no espaço imagem com precisão subpixel.

As coordenadas de quatro pontos de apoio foram determinadas utilizando receptores GNSS, com rastreio de oito horas de duração e de forma simultânea. Foram ainda coletadas 42 imagens do campo de calibração utilizando uma câmara Hasselblad H4D de 50 Mpixels equipada com uma lente de $35 \mathrm{~mm}$, cedida pela empresa Sensormap (Moraes et al., 2013). Com os quatro pontos de apoio e as 42 imagens foi realizado o processo de fototriangulação para a determinação das coordenadas dos vértices dos demais alvos. A precisão obtida para as coordenadas destes pontos ficou em torno de $3 \mathrm{~mm}$.

Os campos bidimensionais utilizados consistem em duas placas planas, sendo que uma delas (Figura 1.b) utiliza o mesmo padrão de alvos ArUco que o campo 3D e a outra no padrão de alvos de reconhecimento automático do programa Photomodeler (Figura 1.c).

A placa 2D, com alvos no padrão ArUco, é composta por 48 alvos, totalizando 192 cantos que podem ser medidos. Os pontos de controle foram medidos utilizando os valores nominais da impressão, conferidos com medidas de distância realizadas com um paquímetro de 2 metros, com precisão de $0,2 \mathrm{~mm}$. A placa $2 \mathrm{D}$, com alvos no padrão do PhotoModeler, possui 4 alvos codificados nos cantos que são identificados pelo código circular e 96 alvos circulares, identificados automaticamente por vizinhança, contabilizando 100 alvos. Para refinar a localização automática dos alvos, o PhotoModeler utiliza o método LSM (Least Square Matching), atingido precisão subpixel (Alsadik et al., 2013).

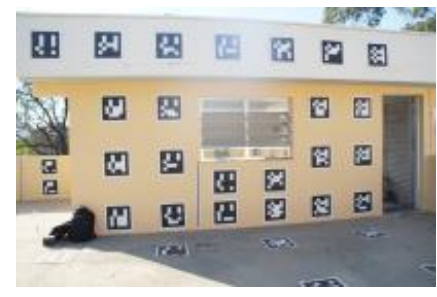

(a)

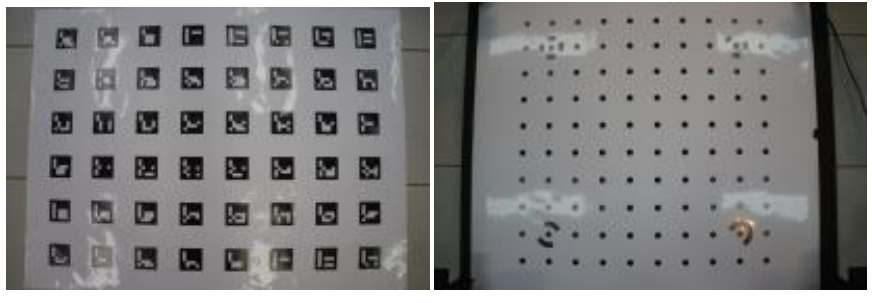

(b) (c)

Figura1: (a) Campo de Calibração 3D - FCT/UNESP, (b) Placa 2D no padrão ArUco, (c) Placa 2DPhotoModeler. 


\section{Metodologia}

As técnicas aplicadas na aquisição e processamento dos dados visam atender a dois objetivos específicos: realizar uma análise comparativa entre os POI obtidos a partir dos campos de calibração 3D e 2D e avaliar a influência desses resultados em experimentos práticos de fototriangulação. Na aquisição das imagens para calibração utilizou-se a câmara Sony-Nex, com objetiva de $18 \mathrm{~mm}$. Os detalhes sobre a câmara utilizada são apresentados na Tabela 1.

Tabela 1: Informações técnicas sobre a câmara Sony Nex.

\begin{tabular}{c|c}
\hline Câmara & Sony Nex \\
\hline Distância Focal nominal & $18,0 \mathrm{~mm}$ \\
\hline Tipo/Tamanho do sensor & $\mathrm{CMOS} / 23 \mathrm{~mm} \times 15 \mathrm{~mm}$ \\
\hline Tamanho do pixel & $0,0047 \mathrm{~mm}$ \\
\hline Dimensões da imagem & $4912 \times 3264$ pixels \\
\hline
\end{tabular}

Para o processo de calibração e estimação dos POI, foram realizadas 3 coletas de dados, em três campos de calibração (Figura 1), baseadas no método de calibração em campo com ajustamento por feixes de raios e com a configuração de câmaras convergentes (Seção 3). Os três conjuntos de dados são caracterizados pelo campo utilizado (2D ou 3D), o programa de identificação automática dos alvos e o programa de processamento.

1) Calibração utilizando campo $3 \mathrm{D}$, com alvos no padrão ArUco, programa científico CMC e programa de identificação e medida automática de alvos (Localizador de alvos), ambos desenvolvidos pelo grupo de pesquisa em Fotogrametria da FCT/UNESP.

2) Calibração com placa 2D, com alvos no padrão ArUco, programa científico CMC e programa de identificação e medida automática de alvos.

3) Calibração utilizando placa 2D, com alvos no padrão do PhotoModeler e o programa comercial PhotoModeler. A placa 2D de reconhecimento automático deste experimento é disponibilizada pelo próprio fabricante no site do programa.

A partir desses três conjuntos de dados foram processadas as calibrações obtendo-se os POI: distância focal, coordenadas do ponto principal, parâmetros da distorção radial simétrica e parâmetros da distorção descentrada. O programa CMC utiliza o modelo de afinidade apresentado por Habib e Morgan (2003). Entretanto os parâmetros de afinidade não foram utilizados na calibração da câmara, em nenhum dos experimentos porque o programa PhotoModeler, não possui modelo de afinidade, o que impossibilitaria a comparação entre os resultados das calibrações. Além disso, para câmaras digitais modernas o efeito da afinidade, na maioria dos casos é inferior ao erro de medida.

Em um primeiro momento, foi realizada uma análise individual da qualidade dos resultados de cada calibração, avaliando-se os desvios padrão dos POI, os resíduos das observações, o número de iterações e o sigma a posteriori, seguido de uma análise comparativa entre os valores obtidos nos campos 3D e 2D e por diferentes programas.

Considerando a importância dos POI no desenvolvimento dos produtos fotogramétricos, e com a crescente aplicabilidade da Fotogrametria na modelagem tridimensional de objetos, é importante avaliar a influência das diferenças entre os resultados dos valores de POI obtidos nos diferentes processos de calibração. Nesse sentido, avaliou-se esta influência no cálculo das coordenadas 3D de pontos no espaço objeto a partir de um tripleto de imagens, estimando-se as discrepâncias entre as coordenadas calculadas e as coordenadas de referência dos alvos, através 
da média, desvio padrão e a Raiz quadrada do Erro Médio Quadrático (REMQ) das discrepâncias encontradas.

A REMQ é estimada pela raiz quadrada da somatória das discrepâncias ao quadrado, como apresenta a Equação11.

$$
\mathrm{REMQ}=\sqrt{\frac{1}{\mathrm{~N}} \cdot \sum_{\mathrm{i}=1}^{\mathrm{n}}(\text { Estimado }- \text { Referência })^{2}}
$$

Uma vez determinados os POI por calibração de campo, pode se utilizar a câmara em projetos fotogramétricos, desde que estes parâmetros sejam estáveis. Para o cálculo das coordenadas de pontos fotogramétricos no espaço objeto foram realizados dois grupos de experimentos, que correspondem às técnicas comumente usadas na modelagem tridimensional de objetos. No primeiro experimento admitiu-se a hipótese de que a orientação exterior (OE) era conhecida (orientação direta obtida por Sistemas de Orientação Direta, como sistemas integrando receptores GNSS e Unidade Inercial ou por Topografia Clássica), possibilitando analisar a compatibilidade entre os três modelos. Em um segundo momento, considerou-se os parâmetros de OE desconhecidos (orientação indireta), estimando-os no processo de Fototriangulação.

Além disso, foram avaliadas as discrepâncias obtidas no plano que contém os pontos de controle (in-plane) e fora do plano (out-of-plane), separadamente, para discutir a influência dos parâmetros de orientação interior na acurácia das coordenadas em profundidades distintas (Fraser, 2012). Para isso foram utilizadas as coordenadas estimadas no processo de Fototriangulação, com orientação exterior indireta, e POI fixos apenas do experimento 1 e do experimento 2, que utilizam os mesmos programas de identificação automática de alvos e de processamento da calibração, constituindo dois conjuntos de dados compatíveis. Mais detalhes sobre os experimentos serão apresentados na Seção 5.

\section{Experimentos e Resultados}

O primeiro conjunto de experimento refere-se à calibração da câmara Sony Nex com os três conjuntos de dados descritos na Seção 4.

As imagens do campo de calibração 3D foram coletadas em 5 de setembro de 2013. Para os campos bidimensionais, as aquisições ocorreram em 6 de setembro de 2013, respeitando a mesma geometria de aquisição e sem alterar a focalização do sistema de lentes.

\subsection{Parâmetros de Orientação Interior}

O CMC e o PhotoModeler possuem algumas diferenças na forma de apresentação do resultado final. É necessário, portanto, compatibilizar os dados para uma análise coerente dos POI. Com relação às coordenadas do ponto principal, o CMC apresenta o resultado com relação ao centro da imagem, enquanto o PhotoModeler utiliza como origem o canto superior esquerdo da mesma. Logo, para compatibilizar as medidas, aplicou-se uma translação na origem do PhotoModeler 
para o centro da imagem e, a partir da nova origem, determinou-se as coordenadas do ponto principal no mesmo sistema de referência do CMC.

Outra diferença está nos parâmetros de distorção radial simétrica e de distorção descentrada. O CMC fornece os coeficientes de distorção, enquanto o PhotoModeler disponibiliza coeficientes para a correção da distorção, que possuem o sinal inverso. A Tabela 2 apresenta os POI estimados, já compatibilizados para o padrão utilizado pelo CMC, e os respectivos desvios padrão fornecidos pelos programas a partir dos três conjuntos de dados (Seção 4).

Tabela 2: - Parâmetros de orientação interior obtidos a partir dos três experimentos.

\begin{tabular}{c|c|c|c}
\hline POI & $\begin{array}{c}\text { Experimento 1 } \\
\text { (3D e CMC) }\end{array}$ & $\begin{array}{c}\text { Experimento 2 } \\
\text { (2D e CMC) }\end{array}$ & $\begin{array}{c}\text { Experimento 3 } \\
\text { (2D e PhotoModeler) }\end{array}$ \\
\hline $\mathrm{f}(\mathrm{mm})$ & $18,1456 \pm 0,004$ & $18,1749 \pm 0,010$ & $18,8180 \pm 0,006$ \\
\hline $\mathrm{x}_{0}(\mathrm{~mm})$ & $-0,0637 \pm 0,002$ & $-0,1417 \pm 0,005$ & $-0,2155 \pm 0,002$ \\
\hline $\mathrm{y}_{0}(\mathrm{~mm})$ & $-0,0299 \pm 0,002$ & $0,0141 \pm 0,004$ & $0,0134 \pm 0,003$ \\
\hline $\mathrm{k}_{1}\left(\mathrm{~mm}^{-2}\right)$ & $-5,9992 \times 10^{-4} \pm 7,88 \times 10^{-6}$ & $-5,8816 \times 10 \pm 7,03 \times 10^{-6}$ & $-5,358 \times 10^{-4} \pm 2,50 \times 10^{-6}$ \\
\hline $\mathrm{k}_{2}\left(\mathrm{~mm}^{-4}\right)$ & $5,8899 \times 10^{-7} \pm 1,207 \times 10^{-7}$ & $5,8606 \times 10^{-7} \pm 1,219 \times 10^{-7}$ & $6,823 \times 10^{-7} \pm 1,7 \times 10^{-8}$ \\
\hline $\mathrm{k}_{3}\left(\mathrm{~mm}^{-6}\right)$ & $3,412 \times 10^{-9} \pm 5,64 \times 10^{-10}$ & $2,817 \times 10^{-9} \pm 6,29 \times 10^{-10}$ & $0,000 \pm 000$ \\
\hline $\mathrm{p}_{1}\left(\mathrm{~mm}^{-1}\right)$ & $-1,1843 \times 10^{-5} \pm 3,47 \times 10^{-6}$ & $-1,5256 \times 10^{-4} \pm 5,56 \times 10^{-6}$ & $-1,573 \times 10^{-4} \pm 1,4 \times 10^{-6}$ \\
\hline $\mathrm{p}_{2}\left(\mathrm{~mm}^{-1}\right)$ & $2,1938 \times 10^{-5} \pm 3,3371 \times 10^{-6}$ & $8,82707 \times 10^{-6} \pm 5,0859 \times 10^{-6}$ & $3,244 \times 10^{-5} \pm 2,0 \times 10^{-6}$ \\
\hline
\end{tabular}

\subsection{Análise Comparativa}

Com os dados homogeneizados foi realizada uma análise comparativa entre os resultados obtidos com o campo 3D e o campo 2D, calculando-se as discrepâncias dos POI entre os experimentos 1 e 2 , assim como,entre os experimentos 1 e 3 . A Tabela 3 mostra as diferenças entre os valores encontrados nos experimentos 2 e 3 com relação ao experimento 1 .

Tabela 3: Diferenças entre os POI obtidos nos experimentos.

\begin{tabular}{c|c|c}
\hline Parâmetros & Exp. 1 - Exp. 2 & Exp.1- Exp.3 \\
\hline $\mathrm{f}(\mathrm{mm})$ & $-0,0293$ & $-0,6724$ \\
\hline $\mathrm{x}_{0}(\mathrm{~mm})$ & 0,0780 & 0,1517 \\
\hline $\mathrm{y}_{0}(\mathrm{~mm})$ & $-0,0440$ & $-0,0433$ \\
\hline $\mathrm{k}_{1}\left(\mathrm{~mm}^{-2}\right)$ & $1,17 \times 10^{-5}$ & $-6,41 \times 10^{-5}$ \\
\hline $\mathrm{k}_{2}\left(\mathrm{~mm}^{-4}\right)$ & $2,92 \times 10^{-9}$ & $-9,33 \times 10^{-8}$ \\
\hline $\mathrm{k}_{3}\left(\mathrm{~mm}^{-6}\right)$ & $5,95 \times 10^{-10}$ & $3,41 \times 10^{-9}$ \\
\hline $\mathrm{p}_{1}\left(\mathrm{~mm}^{-1}\right)$ & $1,41 \times 10^{-4}$ & $1,45 \times 10^{-4}$ \\
\hline $\mathrm{p}_{2}\left(\mathrm{~mm}^{-1}\right)$ & $1,31 \times 10^{-5}$ & $-1,05 \times 10^{-5}$ \\
\hline
\end{tabular}

As maiores diferenças são encontradas na distância focal e na coordenada $\mathrm{x}$ do ponto principal $\left(\mathrm{x}_{0}\right)$. Apesar das diferenças nas geometrias dos campos de calibração 3D e 2D, os parâmetros de distorção radial simétrica obtidos nas três calibrações, assim como os parâmetros de distorção descentrada são semelhantes. As curvas de distorção radial simétrica podem ser visualizadas na Figura 2. 


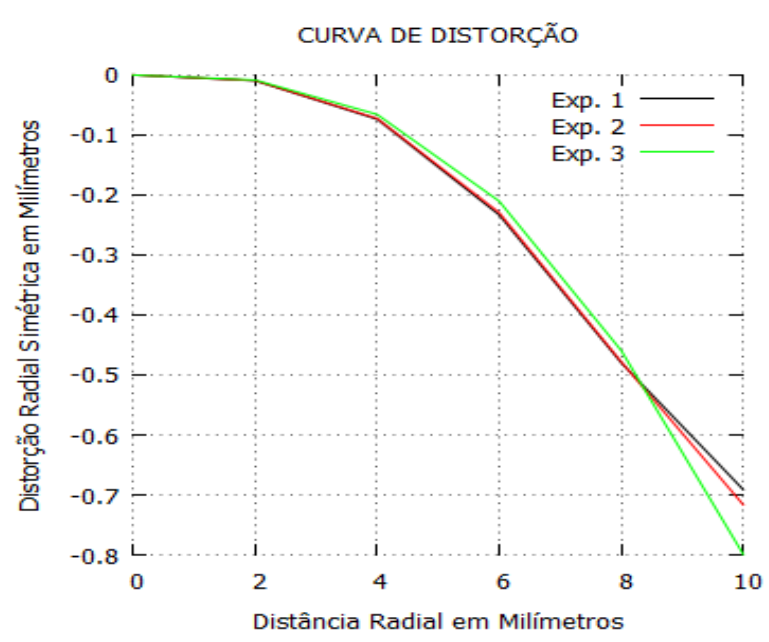

Figura 2: Curva da distorção radial simétrica.

Para avaliar a influência dos resultados obtidos e compreender o impacto das diferenças obtidas nos valores de $\mathrm{x}_{0}$, e principalmente, da distância focal, realizou-se um novo grupo de experimentos, nos quais objetiva-se calcular as coordenadas de terreno dos pontos de controle de um tripleto de imagens (Figura 3) e avaliar as discrepâncias encontradas.

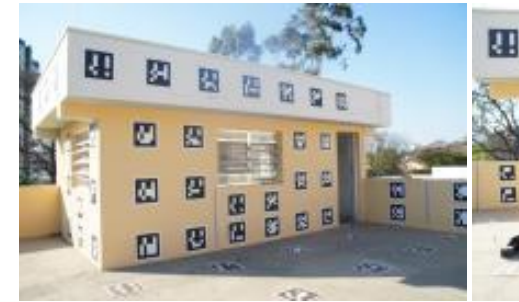

(1)

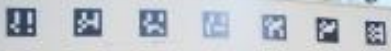

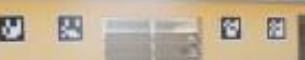

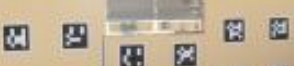

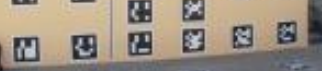

(2)

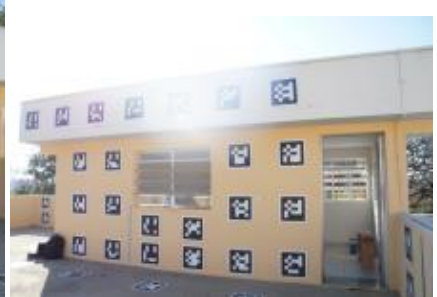

(3)

Figura 3: Tripleto experimental.

\subsection{Verificação da Influência dos POI com Orientação Exterior Direta}

As coordenadas no espaço objeto dos vértices dos alvos ilustrados na Figura 3 são conhecidas, determinadas por processos geodésicos e fotogramétricos, como citado na Seção 3. Para analisar a compatibilidade entre os modelos e os parâmetros obtidos, foram calculadas as coordenadas de terreno dos pontos, no programa CMC, fixando-se os POI obtidos em cada calibração e os parâmetros de orientação exterior (POE). Os POE utilizados neste experimento são provenientes da calibração 3D, que, por apresentarem boa precisão, podem ser considerados como referência, simulando um caso em que os POE fossem medidos diretamente. Os desvios padrão atribuídos às injunções foram: $5 \mathrm{~mm}$ e $0,005^{\circ}$ para os POE e nos POI, $0,5 \mu \mathrm{m}$ para a distância focal, $0,5 \mu \mathrm{m}$ em $x_{0}$ e $y_{0}, 1 \times 10^{-7} \mathrm{~mm}^{-2}, 1 \times 10^{-10} \mathrm{~mm}^{-4}, 1 \times 10^{-12} \mathrm{~mm}^{-6}$, para os coeficiente da distorção radial simétrica, $\mathrm{k}_{1}, \mathrm{k}_{2}$ e $\mathrm{k}_{3}$, respectivamente e $10^{-8} \mathrm{~mm}^{-1}$ para ambos os coeficientes de distorção descentrada $\left(\mathrm{p}_{1}\right.$ e $\left.\mathrm{p}_{2}\right)$.

Foram adotados apenas quatro pontos de controle bem distribuídos, com desvio padrão de $3 \mathrm{~mm}$, sendo o restante dos pontos considerados como pontos de verificação, totalizando 52 pontos de 
verificação. A Figura 4 ilustra a distribuição dos pontos de controle, destacados em vermelho. Neste caso, obtiveram-se as coordenadas de terreno dos pontos de verificação para os três conjuntos de parâmetros resultantes dos experimentos 1,2 e 3 .

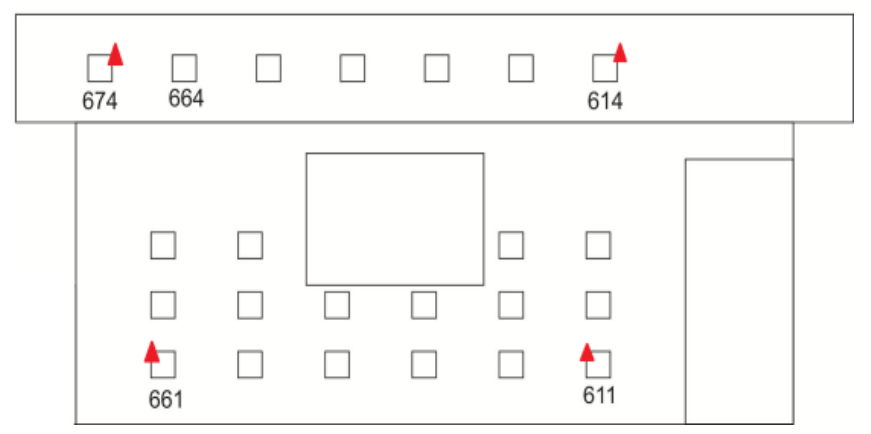

Figura 4: - Distribuição dos pontos de controle no tripleto.

Conhecendo-se as coordenadas de referência dos pontos de verificação, foram calculadas as discrepâncias entre as coordenadas de referência $e$ as coordenadas calculadas por Fototriangulação. A média, desvio padrão e REMQ das discrepâncias são apresentados na Tabela 4.

Tabela 4: Média, desvio padrão e REMQ em pontos de verificação com o uso dos POI dos experimentos 1,2 e 3 e com POE conhecidos.

\begin{tabular}{c|c|c|c|c}
\hline \multirow{4}{*}{ Exp. 1 } & Estatísticas & $\mathbf{X}(\mathbf{m m})$ & $\mathbf{Y}(\mathbf{m m})$ & $\mathbf{Z} \mathbf{( m m})$ \\
\cline { 2 - 5 } & Média & $-0,727$ & 0,255 & 0,091 \\
\cline { 2 - 5 } & Desvio Padrão & 4,476 & 2,976 & 7,162 \\
\cline { 2 - 5 } & REMQ & 4,716 & 3,017 & 7,236 \\
\hline \multirow{3}{*}{ Exp. 2 } & Média & $-8,150$ & 3,923 & 0,048 \\
\cline { 2 - 5 } & Desvio Padrão & 7,512 & 4,393 & 7,748 \\
\cline { 2 - 5 } & REMQ & 11,256 & 5,976 & 7,826 \\
\hline \multirow{3}{*}{ Exp. 3 } & Média & $-21,750$ & 4,173 & 6,615 \\
\cline { 2 - 5 } & Desvio Padrão & 28,981 & 13,768 & 14,019 \\
\cline { 2 - 5 } & REMQ & 36,730 & 14,540 & 15,687 \\
\hline
\end{tabular}

Utilizando os POE fixos nota-se claramente, pela média das discrepâncias, a presença de tendência nos Exp. 2 e Exp. 3, sendo que o maior valor da REMQ está nas coordenadas X, que reflete as discrepâncias entre parâmetros $\mathrm{x}_{0}$,obtidos nos três experimentos (Tabela 3).

O Exp.1 reflete o resultado, esperado neste tipo de calibração, utilizando conjuntos de pontos tridimensionais, com REMQ das coordenadas X e Y próximas à precisão do campo utilizado e o maior valor da REMQ das discrepâncias na coordenada $Z$, em função da geometria da câmara.

Observa-se, também, nos experimentos com campos bidimensionais, que o valor da REMQ na coordenada $\mathrm{Z}$ é superior ao obtido com o uso de campo tridimensional. Isso ocorre em função do valor da distância focal estimada em cada experimento. As discrepâncias obtidas em X, Y (a, b.c) assim como em XYZ (d,e,f), para cada ponto, ampliadas 50 vezes (50:1), podem ser visualizadas na Figura 5 na escala gráfica 1:200. 
Este experimento mostra claramente os erros provocados pela fixação de parâmetros calculados em diferentes condições, como os calculados nos experimentos 2 e 3. Nota-se a presença de tendência nos experimentos 2 e 3 que utilizaram campos planos.

Apesar da relevância destes resultados, é importante lembrar que os POE utilizados nestes experimentos foram estimados durante o processo de calibração com o campo 3D, ou seja, os POI gerados no experimento 1 são compatíveis com estes POE, pois foram estimados simultaneamente. Para estimar independentemente os POE foram realizados os experimentos descritos na seção 5.4 .

(a)

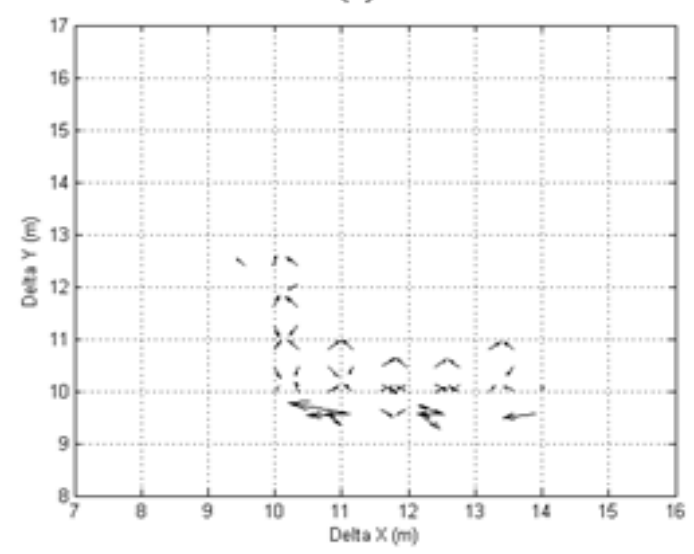

(b)

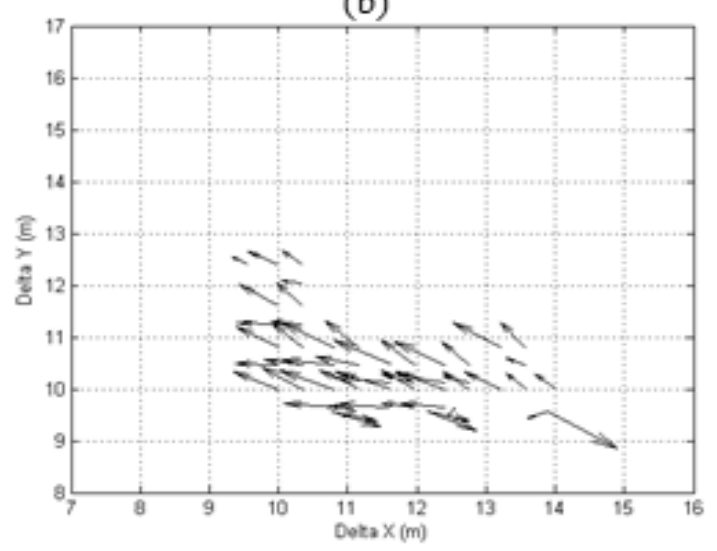

(d)

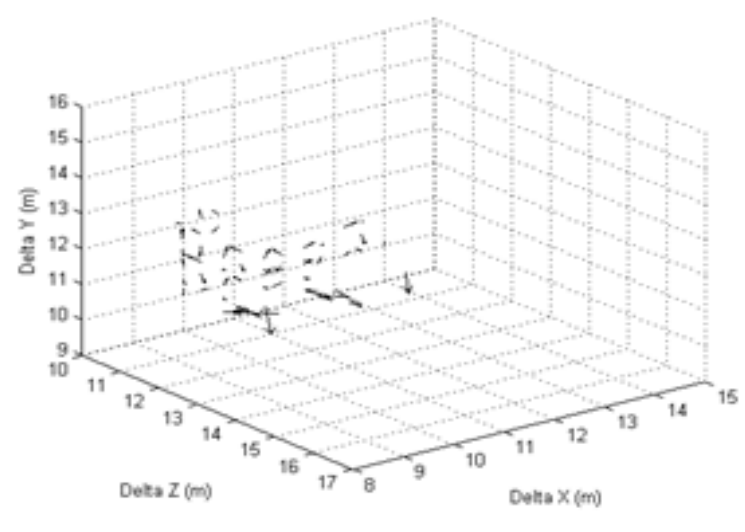

(e)

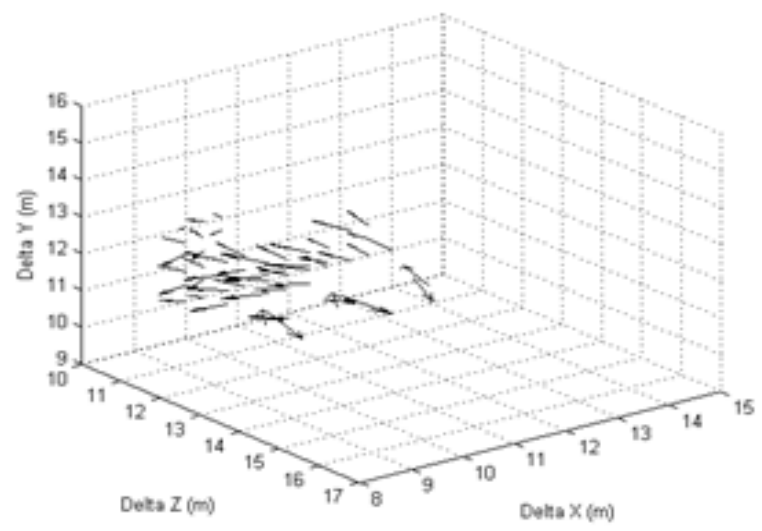


(c)

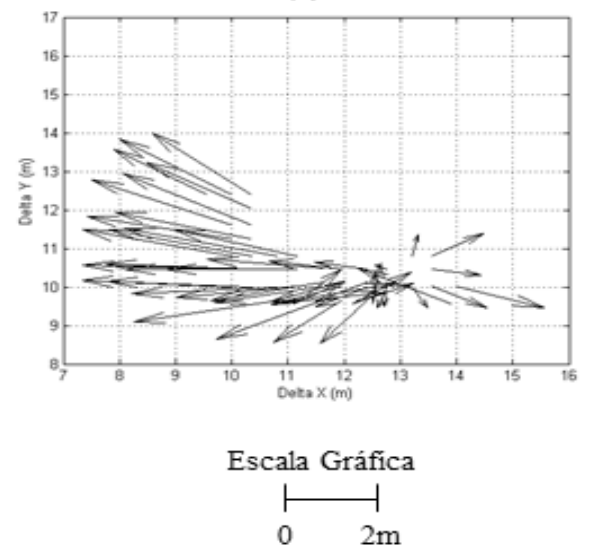

(f)

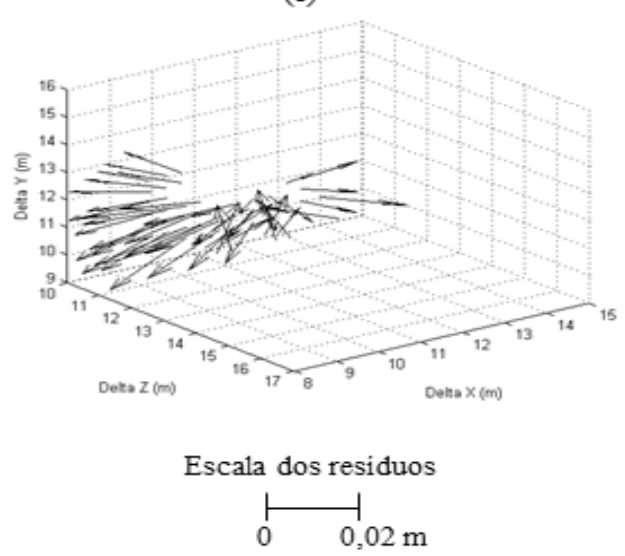

Figura 5: Gráfico das discrepâncias planimétricas / planialtimétricas obtidas para cada ponto considerando em (a/d), (b/e), (c/f), o cálculo das coordenadas do modelo a partir dos POI obtidos nos experimentos 1,2 e 3 , respectivamente, com POE fixo.

\subsection{Verificação da Influência dos Parâmetros de Orientação Interior, com a Determinação dos Parâmetros de Orientação Exterior Indireta}

A Fototriangulação é um processo fotogramétrico que objetiva determinar os parâmetros de orientação exterior e as coordenadas de terreno de pontos fotogramétricos. Nesse sentido, simulando essa aplicação, consideraram-se conhecidos apenas os POI,e tendo-se apenas os parâmetros aproximados para a orientação exterior, foi realizada uma Fototriangulação no programa CMC, sendo utilizados como apoio os quatro pontos apresentados na Figura 4, adotando também desvio padrão de $3 \mathrm{~mm}$

Foram fixados os POI obtidos em cada experimento de calibração para avaliar o impacto destes parâmetros na determinação da orientação exterior do tripleto e nas coordenadas no espaço objeto. Os desvios padrão atribuídos às injunções foram: $0,5 \mu \mathrm{m}$ para a distância focal, $0,5 \mu \mathrm{m}$ em $\mathrm{x}_{0}$ e $\mathrm{y}_{0}, 10^{-7} \mathrm{~mm}^{-2} \mathrm{em} \mathrm{k}_{1}, 10^{-10} \mathrm{~mm}^{-4} \mathrm{em} \mathrm{k}_{2}$, e $10^{-12} \mathrm{~mm}^{-6} \mathrm{em} \mathrm{k}_{3}$, e $10^{-8} \mathrm{~mm}^{-1}$ para ambos os coeficientes de distorção descentrada $\left(\mathrm{p}_{1} \mathrm{e} \mathrm{p}_{2}\right)$. Foram calculadas as discrepâncias entre as coordenadas conhecidas e as coordenadas obtidas em cada experimento de Fototriangulação e, posteriormente, a média, desvio padrão e REMQ das discrepâncias, apresentados na Tabela 5.

Tabela 5: Média, desvio padrão e REMQ referente à aplicação dos POI dos experimentos 1, 2 e 3 .

\begin{tabular}{c|c|c|c|c}
\hline \multirow{4}{*}{ Exp. 1 } & Estatísticas & $\mathbf{X}(\mathbf{m m})$ & $\mathbf{Y ~ ( m m )}$ & $\mathbf{Z}(\mathbf{m m})$ \\
\cline { 2 - 5 } & Média & 0,351 & $-0,893$ & 0,780 \\
\cline { 2 - 5 } & Desvio Padrão & 4,063 & 1,310 & 5,503 \\
\cline { 2 - 5 } & REMQ & 4,079 & 1,296 & 5,606 \\
\hline \multirow{3}{*}{ Exp. 2 } & Média & 0,229 & $-3,250$ & 1,410 \\
\cline { 2 - 5 } & Desvio Padrão & 3,977 & 2,924 & 5,735 \\
\cline { 2 - 5 } & REMQ & 3,983 & 4,398 & 5,908 \\
\hline \multirow{3}{*}{ Exp. 3 } & Média & $-2,130$ & $-2,970$ & $-6,080$ \\
\cline { 2 - 5 } & Desvio Padrão & 9,100 & 9,096 & 6,409 \\
\cline { 2 - 5 } & REMQ & 9,350 & 9,579 & 8,879 \\
\hline
\end{tabular}


A média das discrepâncias permitiu detectar a presença de tendências que foram provocadas pelos POI utilizados e, portanto, por erros sistemáticos residuais, bem como pela geometria e distribuição dos pontos de controle. Nos experimentos 2 e 3, onde utilizou-se POI provenientes de calibrações com campos bidimensionais, observa-se uma maior tendência , principalmente, nas coordenadas Z. Entretanto é possível observar graficamente que as discrepâncias possuem padrão aleatório (Figura 6), ao contrário dos resultados apresentados na Figura 5, quando se utilizaram POE fixos. As discrepâncias obtidas em X, Y (a,b.c) assim como em XYZ (d,e,f),para cada ponto, ampliadas 50 vezes $(50: 1)$, podem ser visualizadas na Figura 6, com escala gráfica $1: 200$.
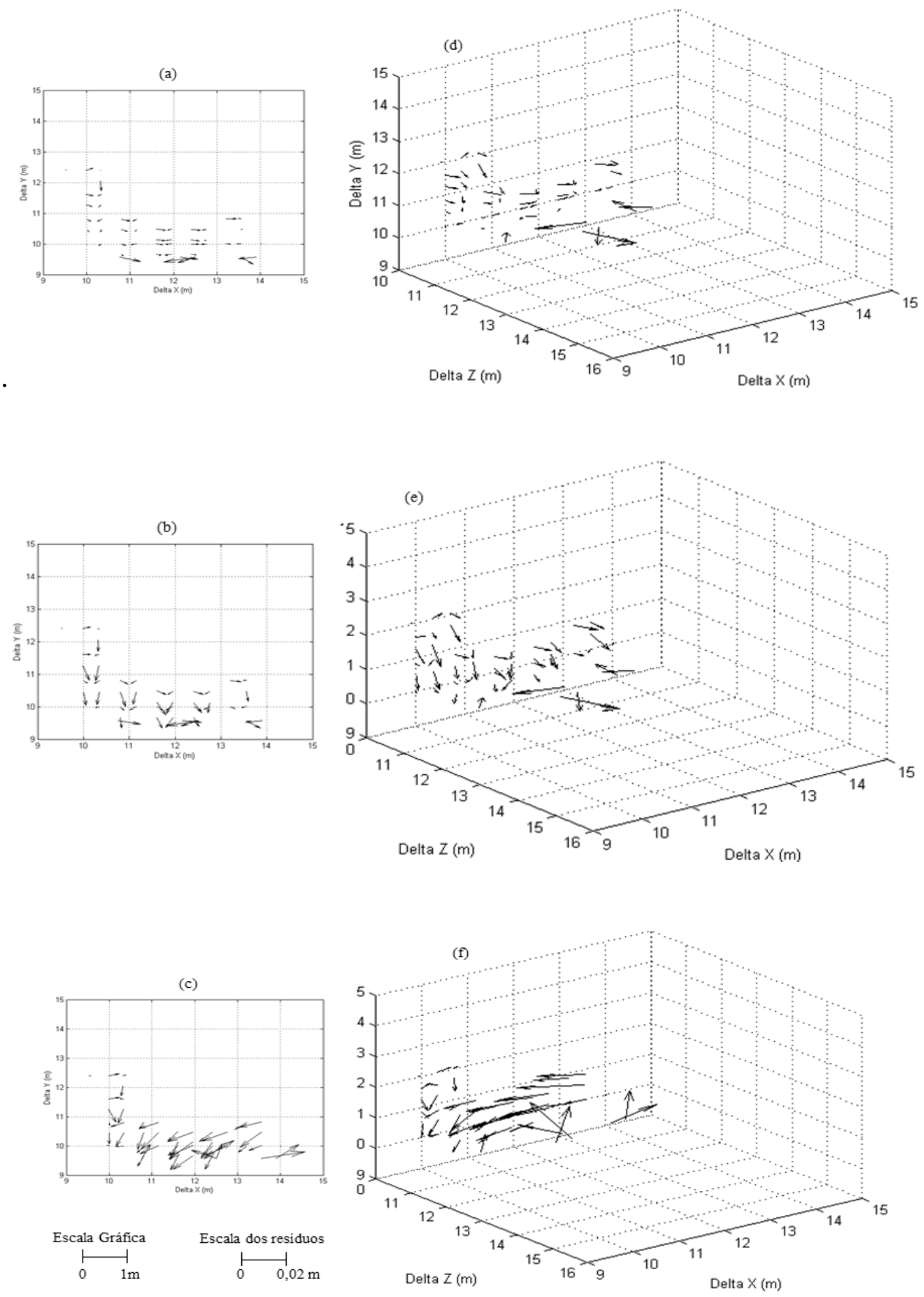

Figura 6: Gráfico das discrepâncias planimétricas / planialtimetricas obtidas para cada ponto considerando em (a/d), (b/e), (c/f), o cálculo das coordenadas do modelo a partir dos POI obtidos nos experimentos 1,2 e 3 , respectivamente, com POE estimados. 
Neste caso, as discrepâncias entre os POI obtidos nos experimentos 2 (2D/CMC) e 3 (2D/PhotoModeler), com relação ao experimento 1 (3D/CMC), foram em grande parte absorvidas pelos POE, no processo de ajustamento, o que justifica a melhora dos resultados. Ainda assim, os melhores resultados foram aqueles obtidos com o campo tridimensional.

Os POE obtidos nas três calibrações apresentam discrepâncias de valores entre si, principalmente em função da absorção dos efeitos dos POI. Nesse sentindo, a Tabela 6 apresenta as discrepâncias entre os POE obtidos por Fototriangulação com POI estimados na calibração com o campo 3D e com POI estimados na calibração com ambos os campos bidimensionais. Na Tabela $6 \Delta \mathrm{E} 1$-E2 são as discrepâncias entre os POE obtidos com os campo 3D e2D, ambos com alvos no padrão ArUco e $\triangle \mathrm{E} 1-\mathrm{E} 3$ são as discrepâncias entre os POE relacionados aos POI obtidos com campo 3D, e aos POI do campo bidimensional no padrão PhotoModeler, ambos para as três imagens do tripleto.

Tabela 6: - Discrepâncias entre os POE calculados a partir dos POI obtidos na calibração com campos bidimensionais com relação ao campo tridimensional.

\begin{tabular}{|c|c|c|c|c|c|c|c|}
\hline \multirow{5}{*}{$\Delta \mathrm{E} 1-\mathrm{E} 2$} & Imagem & $\omega\left(^{\circ}\right)$ & $\varphi\left({ }^{\circ}\right)$ & $\kappa\left({ }^{\circ}\right)$ & $\mathbf{X}_{0}(\mathbf{m})$ & $Y_{0}(\mathbf{m})$ & $\mathrm{Z}_{0}(\mathrm{~m})$ \\
\hline & 1 & 0,1271 & 0,2948 & $-0,0916$ & 0,0073 & 0,0028 & 0,0057 \\
\hline & 2 & 0,1254 & 0,2220 & 0,0242 & $-0,0041$ & 0,0031 & 0,0087 \\
\hline & 3 & 0,1720 & 0,2176 & 0,0965 & $-0,0085$ & 0,0005 & 0,0056 \\
\hline & Média & 0,1415 & 0,2448 & 0,0097 & $-0,0017$ & 0,0021 & 0,0066 \\
\hline \multirow{4}{*}{$\Delta \mathbf{E 1 - E 3}$} & 1 & 0,6059 & 1,7422 & $-0,1559$ & 0,1564 & $-0,0478$ & 0,1062 \\
\hline & 2 & 0,1376 & 0,6218 & 0,0495 & $-0,0255$ & 0,0113 & 0,1836 \\
\hline & 3 & 0,3873 & 0,1809 & 0,0314 & $-0,1437$ & $-0,0239$ & 0,1430 \\
\hline & Média & 0,3769 & 0,8483 & $-0,0249$ & $-0,0042$ & $-0,0201$ & 0,1442 \\
\hline
\end{tabular}

Em ambos os experimentos as maiores discrepâncias nos ângulos de atitude ocorreram no ângulo $(\varphi)$, que está correlacionado com a coordenada $X$, o que absorve as diferenças entre os valores de $\mathrm{x}_{0}$.

Quanto à posição, as maiores discrepâncias ocorreram em $\mathrm{Z}_{0}$, devido à correlação deste parâmetro com a distância focal. A maior discrepância em $\mathrm{Z}_{0}$ é observada em $\Delta \mathrm{E} 1-\mathrm{E} 3$, devido à diferença significativa entre os valores da distância focal obtidos na calibração nos experimentos 1 (campo 3D) e 3 (POI estimados com o campo plano pelo Photomodeler), como apresentado na Tabela 5. Os coeficientes de correlação entre $f$ e $Z_{0}$, e $\mathrm{x}_{0}$ e $\varphi$, para as três imagens do tripleto e para os três experimentos podem ser observados na Tabela 7.

Tabela 7: Coeficientes de correlação entre os POI e os POE nas três imagens do tripleto para os três experimentos.

\begin{tabular}{c|c|c|c|c}
\hline Parâmetros correlacionados & Experimentos & \multicolumn{3}{|c}{ Coeficiente de correlação } \\
\cline { 3 - 5 } & & Imagem & Imagem & Imagem \\
& & $\mathbf{1}$ & $\mathbf{2}$ & $\mathbf{3}$ \\
\hline \multirow{3}{*}{$f \mathrm{e} \mathrm{Z} \mathrm{Z}_{0}$} & $(3 \mathrm{D} / \mathrm{CMC})$ & 0,00 & 0,02 & 0,01 \\
\cline { 2 - 5 } & $(2 \mathrm{D} / \mathrm{CMC})$ & 0,02 & 0,04 & 0,04 \\
\cline { 2 - 5 } & $(2 \mathrm{D} /$ PhotoModeler $)$ & 0,01 & 0,02 & 0,02 \\
\hline \multirow{3}{*}{$\mathrm{x}_{0} \mathrm{e} \varphi$} & $(3 \mathrm{D} / \mathrm{CMC})$ & 0,00 & 0,00 & 0,00 \\
\cline { 2 - 5 } & $(2 \mathrm{D} / \mathrm{CMC})$ & 0,03 & 0,03 & 0,05 \\
\cline { 2 - 5 } & $(2 \mathrm{D} /$ PhotoModeler $)$ & 0,02 & 0,01 & 0,03 \\
\hline
\end{tabular}


Para verificar como as variações nos POI afetam os pontos determinados no espaço objeto, foram calculados separadamente a média, desvio padrão e REMQ, das coordenadas no plano dos pontos de apoio (in-plane, Tabela 8) e fora deste plano (out-of-plane-Tabela9) para os experimentos1 e 2, que apresentaram a maior discrepância entre os coeficientes de correlação.

As calibrações nos experimentos 1 e 2 foram realizadas utilizando o mesmo padrão de alvos e o mesmo programa de processamento, o que permite avaliar a influência da utilização do campo $3 \mathrm{D}$ e $2 \mathrm{D}$ nas coordenadas no plano dos pontos de apoio e fora deste plano.

Tabela 8: Média, desvio padrão e REMQ das discrepâncias das coordenadas no plano dos pontos de apoio.

\begin{tabular}{c|c|c|c|c}
\hline \multirow{3}{*}{$\begin{array}{c}\text { Exp. 1 } \\
\text { (POI de campo 3D) }\end{array}$} & Estatísticas & $\mathbf{X}(\mathbf{m m})$ & $\mathbf{Y ~ ( \mathbf { m m } )}$ & $\mathbf{Z}(\mathbf{m m})$ \\
\cline { 2 - 5 } & Media & 0,688 & $-0,540$ & 1,466 \\
\cline { 2 - 5 } & Desvio Padrão & 2,446 & 0,448 & 2,272 \\
\cline { 2 - 5 } & REMQ & 2,510 & 0,697 & 2,679 \\
\hline \multirow{2}{*}{ Exp. 2 } & Media & 0,272 & $-2,74$ & 2,184 \\
\cline { 2 - 5 } & Desvio Padrão & 2,503 & 2,452 & 3,072 \\
\cline { 2 - 5 } & REMQ & 2,441 & 3,594 & 3,673 \\
\hline
\end{tabular}

A REMQ nas coordenadas no plano dos pontos de apoio (in-plane) do primeiro experimento são inferiores a $3 \mathrm{~mm}$ (precisão média dos pontos de controle) em todas as componentes, enquanto que as coordenadas no plano dos pontos de apoio, nas componentes $\mathrm{Y}$ e $\mathrm{Z}$, no experimento 2 são superiores a $3 \mathrm{~mm}$. Observando a média constata-se a presença de tendência nessas componentes.

Tabela 9: Média, desvio padrão e REMQ das discrepâncias das coordenadas fora do plano dos pontos de apoio.

\begin{tabular}{c|c|c|c|c}
\hline \multirow{4}{*}{$\begin{array}{c}\text { Exp. 1 } \\
\text { (POI de campo 3D) }\end{array}$} & Estatísticas & $\mathbf{X}(\mathbf{m m})$ & $\mathbf{Y}(\mathbf{m m})$ & $\mathbf{Z}(\mathbf{m m})$ \\
\cline { 2 - 5 } & Media & $-1,690$ & $-2,210$ & $-3,650$ \\
\cline { 2 - 5 } & Desvio Padrão & 7,204 & 2,423 & 8,912 \\
\cline { 2 - 5 } & REMQ & 7,424 & 3,367 & 9,707 \\
\hline \multirow{2}{*}{ Exp. 2 } & Media & $-0,420$ & $-2,070$ & $-0,840$ \\
\cline { 2 - 5 } & Desvio Padrão & 7,297 & 2,336 & 10,866 \\
\cline { 2 - 5 } & REMQ & 7,308 & 3,194 & 10,900 \\
\hline
\end{tabular}

Por outro lado, a REMQ é maior nas coordenadas fora deste plano (out-of-plane) quando comparada à REMQ das coordenadas in-plane, em todas as componentes, mas a maior REMQ das discrepâncias está na componente $\mathrm{Z}$.

Comparando os dois experimentos, a REMQ varia 1,5\% em X e 5\% em Y, enquanto em $\mathrm{Z}$ a diferença entre os campos 3D e 2D é de 12\%. O aumento das discrepâncias em $\mathrm{Z}$ é esperado, pois, o campo $2 \mathrm{D}$ não apresenta variação da componente $Z$, o que dificulta a redução de dependência linear da coordenada Z do C. P. com a distância focal (Merchant, 1979; Andrade, 1981; Côrtez, 2010; Debiase, 2012).

A análise das discrepâncias das coordenadas em $\mathrm{Z}$ é interessante, pois reflete o impacto da determinação da distância focal, com o campo 3D e com o campo 2D. A diferença entre os valores da distância focal dos dois experimento é de $0,16 \%$, como apresentado na Tabela 3 , sendo 
o valor da REMQ para a coordenada $\mathrm{Z}$, com o plano $2 \mathrm{D}, 12 \%$ maior que para o plano $3 \mathrm{D}$ em coordenadas out-of-plane.

\section{Considerações Finais}

A análise comparativa mostrou que as maiores diferenças entre os POI estimados ocorreu na distância focal. Isso ocorre porque o campo de calibração 3D permite a redução de correlação entre os valores da distância focal $(\mathrm{OI})$ e de $\mathrm{Z}_{0}(\mathrm{OE})$ de modo mais efetivo que no campo $2 \mathrm{D}$ (Tabela 7). A calibração com a placa 2D apresenta maiores correlações, mesmo com a aplicação do método de câmaras convergentes.

Para a análise da influência dos POI obtidos nos três experimentos de calibração, foram realizados testes simulando a existência de parâmetros de orientação exterior determinados direta e indiretamente. Com a orientação exterior direta, mesmo considerando os POE estimados simultaneamente com o conjunto de pontos tridimensionais, foi possível constatar algumas discrepâncias entre os POI estimados por diferentes configurações e programas.

Pela análise das discrepâncias apresentadas na Figura 5.a, é possível verificar que as discrepâncias apresentam padrão aleatório, o que indica que não há erros sistemáticos residuais, ou seja, os POI foram determinados com pouca correlação com os POE neste campo 3D. Nos campos 2D, por sua vez, é visível a presença de tendência em ambos os experimentos, o que indica que os POIs não foram determinados com precisão.

O cálculo das coordenadas de pontos no espaço objeto e da orientação exterior por Fototriangulação mostrou que, parte da influência da orientação interior, pode ser absorvida pela OE. Entretanto, ainda nota-se o impacto dos diferentes valores da distância focal no cálculo das coordenadas em Z. Essa diferença foi avaliada comparando-se a média, desvio padrão e REMQ das coordenadas no plano dos pontos de apoio (in-plane) e fora deste plano (out-of-plane).

Os campos 2D são amplamente utilizados pelos usuários pela facilidade em sua implantação e, principalmente, pela facilidade na identificação automática dos alvos devido à possibilidade de uso de relações de vizinhança.

Entretanto, em algumas aplicações, como em Fotogrametria Arquitetural, é importante avaliar os métodos de calibração em relação ao projeto. Para o levantamento de fachadas, por exemplo, a calibração utilizando campo 2D pode ser viável, desde que a aquisição das imagens para a calibração seja feita com distância similar à aplicada no projeto, como discutido por Brown (1971), Wang (2008) e Córdoba (2012).

Entretanto, para aplicações como a modelagem 3D de estruturas e bens arquitetônicos em geral, a calibração com o campo tridimensional possibilita parâmetros de orientação interior mais adequados.

\section{AGRADECIMENTOS}

Os Autores gostariam de agradecer a Fundação de Amparo à Pesquisa do Estado de São Paulo (FAPESP) - Processo: 2013/ 15940-9, ao Conselho Nacional de Desenvolvimento Científico e 
Tecnológico (CNPQ) - Processo: 130505/2013, e ao Programa de Pós Graduação em Ciências Cartográficas (PPGCC).

\section{REFERÊNCIAS BIBLIOGRÁFICAS}

Alsadik, Bashar with Fabio Remondino, Fabio Menna, Markus Gerke, and George Vosselman. "Robust extraction of image correspondences exploiting the image scene geometry and approximate camera orientation". International Archives of the Photogrammetry, Remote Sensing and Spatial Information Sciences 40 (2013): 1-7.

Andrade, José. B. Fotogrametria. Curitiba: SBEE, 1998.

Andrade, José B. and Mary Olivas A. A. "Calibração de Câmaras Aerofotogramétricas". Boletim de Ciências Geodésicas da Universidade Federal do Paraná 1, no 26 (1981): 1-39.

Aruco: A minimal library for Augmented Reality applications based on OpenCv. Accessed in July 3, $2012<$ http://www.uco.es/investiga/grupos/ava/node/26>.

Bazan, Wimerson S. with Antonio M. G. Tommaselli, Mauricio Galo and Roberto S. Ruy. "Influência das injunções de orientação relativa na calibração de um sistema dual de câmaras". Boletim de Ciências Geodésicas 15, no 3 (2009): 444-466.

Boland, Jonh. "ASPRS Camera calibration: Review painel report executive summary". Paper presented at the ASPRS Annual Conference, Portland, 2000.

Brown, Duane. C. "Decentering distortion of lenses". Photogrammetric Engineering 32 (1966): $444-462$.

Brown, Duane. C. Close-Range Camera Calibration. Photogrammetric Engineering 37 (1971): 855-866.

Brown, Duane. C. "A strategy for multi-camera on-the-job self-calibration". Report, institute of Photogrammetry, University of Stuttgart, 1989.

Clarke, Timothy A. and John G. Fryer. "The development of camera calibration methods and models". Photogrammetric Record 16 (1998):51-66.

Conrady, A. Decentered Lens Systems, Monthly Notices of the Royal Astronomical Society 79 (1919): 384-390.

Córdoba, Paula. A. F. with Antonio A. Nepomuceno, Leonildo S. Silva, and Evangelos Christakou. "Levantamento fotogramétrico digital do palácio Itamaraty de Brasília-DF para projetos de restauração". Paper presented at the Seminário Nacional de Documentação do Patrimônio Arquitetônico com o Uso de Tecnologias Digitais, Belém, 2012.

Côrtes, João. B. R. "Análise da estabilidade geométrica de câmaras digitais de baixo custo com diferentes métodos de calibração". PhD diss., Universidade Federal do Paraná, Curitiba, Paraná, 2010 .

Cramer, Michael. "Euro SDR network on Digital camera calibration". Final Report, Institute of Photogrammetry, University of Stuttgart, 2004.

Debiasi, Paula with Fabiano Hainosz and Edson A. Mitishita. "Calibração em serviço da câmara Digital de baixo custo com o uso de pontos de apoio altimétrico". Boletim de Ciências Geodésicas 18, no 2 (2012): 225-241.

Ebner, Heinrich. "Self-calibrating block adjustment". International Archives of Photogrammetry and Remote sensing 13 (1976): 128-139. 
Eisenhart, Churchill. "Realistic Evaluation of the Precision and Accuracy of Instrument Calibration Systems". Journal of Research of the National Bureau of Standards C67 (1963): 161187.

Eos Systems inc. Photomodeler: photogrammetry measurement and $3 D$ modeling software, 2013. Accessed in July, 8, 2013 < http://www.PhotoModeler.com>.

Fraser, Clive. "Automatic camera calibration in close-range photogrammetry". Paper presented at the ASPRS 2012 Annual Conference 23, Australia, 2012.

Fryer, John. G. "Camera Calibration". In: Close Range Photogrammetry and Machine Vision edited by Keith B. Atkinson, Department of Photogrammetry and Surveying, University College London: Whittles Publishing, 1996, 156-179.

Galo, Mauricio with Antonio M. G Tommaselli, Julio K. Hasegawa and Paulo O. Camargo. "Significância dos parâmetros de orientação interior na calibração de câmaras Automatic camera calibration in close-range photogrammetry". Paper presented at the Simpósio Brasileiro de Ciências Geodésicas e Tecnologias da Geoinformação, Recife, Pernambuco, 2008.

Habib, Ayman and Michel F. Morgan. "Automatic calibration of low-cost Digital cameras". Journal of Optical Engineering 42 (2003): 948-955.

Heikkilä, Janne. "Geometric Camera Calibration Using Circular Control Points", IEEE Transactions on Pattern Analysis and Machine Intelligence 22 (2000): 1066-1077.

Kenefick, Jonh. F. with M S. Gyer, and W F. Harp. Analytical Self-Calibration. Photogrammetric Engineering and Remote Sensing. 40 (1974).

Merchant, Dean. C. Analytical photogrammetry: theory and practice. Notes Revised from Earlier Edition Printed in 1973, The Ohio State University, Ohio State. 1979.

Merchant, Dean. C. “Aerial camera calibration: history and status". Paper presented at the ASPRS 2012 Annual Conference, Califórnia, 2012.

Mitishita, Edson and. Mary Olivas A. A. "Calibração de câmaras aerofotogramétricas a partir de aerofotos digitalizadas”. Boletim de Ciências Geodésicas 7, no 1 (2001): 64-76.

Mitishita, Edson with Paula Debiase, Fabiano Hainosk and Jorge Centeno. Calibration of low cost Digital camera using data from simultaneous Lidar and Photogrammetric survey. International Archives of the Photogrammetry, Remote Sensing and Spatial Information Sciences 39 (2012): 133-138.

Moniwa, Hideya. Analytical Camera Calibration of Close-Range Photogrammetry. PhD diss., University of New Brunswich, Canadá. 1972.

Moraes, Marcus. V. A. with Antonio, M. G. Tommaselli, Sergio L. Silva and José Marcato J. "Implantação de campo terrestre de calibração de câmaras com uso de alvos codificados". Paper presented at the VIII Colóquio Brasileiro de Ciências Geodésicas, Curitiba, Paraná, 2013.

Ruy, Roberto da S. "Desenvolvimento e validação geométrica de um sistema para mapeamento com câmaras digitais de médio formato". PhD diss., UNESP - Universidade Estadual Paulista, Presidente Prudente, 2008.

Silva, Sergio. L. A. with Antonio, M. G. Tommaselli and Almir Artero "Utilização de Alvos Codificados do tipo Aruco na Automatização do Processo de Calibração de Câmaras". Boletim de Ciências Geodésicas 20, no 3 (2014): 636-656.

Tommaselli, Antonio. M. G. and Clésio L. Tozzi. "Técnicas de calibração de câmaras em visão computacional", Paper presented at the Jornada EPUSP/IEEE em Computação Visual, São Paulo,1990. 
Telles, Sandra. S. S. and Antonio M. G. Tommaselli. "A Mathematical model for camera calibration using straight lines" Paper presented at the Euro COW 2005 International Calibration and Orientation Workshop, Castelldefels, Espanha, 2005 (CD-ROM).

Tommaselli, Antonio. M. G. with Laurent Polidori, Julio K. Hasegawa, Paulo O. Camargo, Helio Hirao, Marcus V. A. Moraes, Esrom A. Rissate Jr., Guilherme R. Henrique, Pedro A. G. Abreu, Adilson Berveglieri and José Marcato Jr. "Using vertical panoramic images to record a historic cemetery". International Archives of the Photogrammetry, Remote Sensing and Spatial Information Sciences 40 (2013): 641-646.

Trigg, Bill. Autocalibration from planar scenes. Paper presented at the europe conference of computer vision, Freiburg, 1998.

Wang, Wenjin with Bingxuan Guo, Xin Lib and Jing Cao. "Influence factors evaluation on highprecision planar calibration of non-metric digital camera". The International Archives of the Photogrammetry, Remote Sensing and Spatial Information Sciences 37 (2008): 1071- 1076.

Wolf, Paul and Bon A. Dewitt. Elements of Photogrammetry: with Aplications in GIS. New York: McGRAW-HILL, 2000.

Zhang, Zhengyou. "A flexible new technique for camera calibration". IEEE transactions on pattern analysis and machine intelligence 22 (2000): 1330-1334.

(Recebido em dezembro de 2013. Aceito em dezembro de 2014). 


\title{
LEAST SQUARES FITTING OF ELLIPSOID USING ORTHOGONAL DISTANCES
}

\author{
Adequação do elipsóide usando distâncias ortogonais com mínimos quadrados
}

\author{
SEBAHATTIN BEKTAS \\ OndokuzMayis University, Faculty of Engineering, Geomatics Engineering, 55139 Samsun, \\ sbektas@omu.edu.tr
}

\begin{abstract}
:
In this paper, we present techniques for ellipsoid fitting which are based on minimizing the sum of the squares of the geometric distances between the data and the ellipsoid. The literature often uses "orthogonal fitting" in place of "geometric fitting" or "best-fit". For many different purposes, the best-fit ellipsoid fitting to a set of points is required. The problem of fitting ellipsoid is encountered frequently in theimage processing, face recognition, computer games, geodesy etc. Today, increasing GPS and satellite measurements precision will allow usto determine amore realistic Earth ellipsoid. Several studies have shown that the Earth, other planets, natural satellites, asteroids and comets can be modeled as triaxial ellipsoids Burša and Šima (1980), Iz et al (2011). Determining the reference ellipsoid for the Earth is an important ellipsoid fitting application, because all geodetic calculations are performed on the reference ellipsoid. Algebraic fitting methods solve the linear least squares (LS) problem, and are relatively straightforward and fast. Fitting orthogonal ellipsoid is a difficult issue. Usually, it is impossible to reach a solution with classic LS algorithms. Because they are often faced with the problem of convergence. Therefore, it is necessary to use special algorithms e.g. nonlinear least square algorithms. We propose to use geometric fitting as opposed to algebraic fitting. This is computationally more intensive, but it provides scope for placing visually apparent constraints on ellipsoid parameter estimation and is free from curvature bias Ray and Srivastava (2008).
\end{abstract}

Keywords: Fitting Ellipsoid; Orthogonal Fitting; Algebraic Fitting; Nonlinear Least Square Problem.

Resumo: Neste trabalho, apresentamos a adequação do elipsóide com base na soma dos mínimos quadrados das distâncias geométricas entre os dados e o elipsóide. A literatura muitas vezes aborda a "adequação ortogonal" em lugar da "adequação geométrica" na "melhor adequação". Para muitos propósitos diferentes, a melhor adequação do elipsóide para o conjunto de pontos é necessária. O problema da adequação do elipsóide é encontrado frequentemente no processamento de imagens, reconhecimento de superfícies, jogos de computador, geodésia, etc. Hoje, o aumento da precisão das medidas GPS e de satélites permite que se determine um elipsóide da Terra mais realístico. Diversos estudos, tem demonstrado que a Terra, outros planetas, satélites naturais, asteróides e cometas podem ser modelados com o elipsóides triaxiais, 
Bursa e Sima (1980), Iz et al (2011). Determinar o elipsóide adequado para a Terra é importante porque se aplica a todos os cálculos geodésicos que são executados sobre o elipsóide de referência. Métodos adequados algebricamente resolvem o problema de adequação por mínimos quadrados lineares, e são relativamente rápaidos e diretos. A adequação do elipsóide ortogonal é um assunto difícil. Normalmente, é impossível encontrar uma solução com algorítimos clássicos de mínimos quadrados. A razão é que eles são frequentemente encontrados com problemas de convergência. Portanto, é necessário usar algorítimos especiais, por exemplo, algorítimos de mínimos quadrados com não lineares. Nós propomos o uso da adequação geométrica em contraste com a adequação algébrica. Isto é computacionalmente mais intensivo, mas dá margem ao uso de injunções relativas na estimação a dos parâmetros do elipsóide e elimina as tendências da curvatura, Ray e Srivastava (2008).

Palavras-chave: Adequação do Elipsóide; Adaptação Ortogonal; Adequação Algébrica; Problema de Mínimos Quadrados Não-Linear.

\section{INTRODUCTION}

Fitting an ellipsoid to an arbitrary set of points is a problem of fundamental importance in many wide fields of applied science ranging from astronomy, geodesy, digital image processing and robotics to metrology etc. Ellipsoids, though a bit simple in representing 3D shapes in general, are the only bounded and centric quadrics that can provide information of center and orientation of an object. Fitting ellipsoid has been discussed widely and some excellent work has been done in literature. However, most of these fitting techniques are algebraic fitting, but not orthogonal fitting. Various "least- squares" fitting approaches have been formulated over the years Zhang (1997), but they all fall into two categories; (1) algebraic methods, which are extensively used due to their linear nature, simplicity and computationally efficiency, and (2) geometric methods that solve a nonlinear problemRay and Srivastava (2008).

We could not find enough studies with numerical examples in the literature. Turner et al (1999) gave a numerical application, but the application's data are not given Turner et al (1999). No other comparable orthogonal fitting ellipsoid application could be found in literature. Against this background, the purpose of the study is to give an orthogonal fitting ellipsoid with numerical examples. In this article, we demonstrate that the geometric fitting approach, provides a more robust alternative than algebraic fitting approach-although it is computationally more intensive.

The paper has eight parts. First, the basic ellipsoid will introduce some mathematical equationsto explainthe concepts. Then, it reviews the extended literature relevant to ellipsoid fitting. And we discussed in this research which estimators is used. Next, comes the part which deals with algebraic fitting, orthogonal fitting and numerical example. You will find ellipsoid fitting application based on both $l_{1}$-norm and $l_{2}$-norm methods. The paper concludes with a discussion of theoretical and managerial implications and directions for further research.

\subsection{Ellipsoid}

An ellipsoid is a closed quadric surface that is analogue of an ellipse. Ellipsoid has three different axes $\left(a_{x}>a_{y}>b\right)$ in Figure 1. Mathematical literature often uses "ellipsoid" in place of "Triaxial ellipsoid or General ellipsoid". Scientific literature (particularly geodesy) often uses "ellipsoid" in place of "biaxial ellipsoid, rotational ellipsoid or ellipsoid revolution". Older literature uses 
'spheroid' in place of rotational ellipsoid. The standard equation of an ellipsoid centered at the origin of a cartesian coordinate system and aligned with the axes is shown with this formula:

$$
\frac{x^{2}}{a_{\mathrm{x}}^{2}}+\frac{y^{2}}{a_{y}^{2}}+\frac{z^{2}}{b^{2}}=1
$$

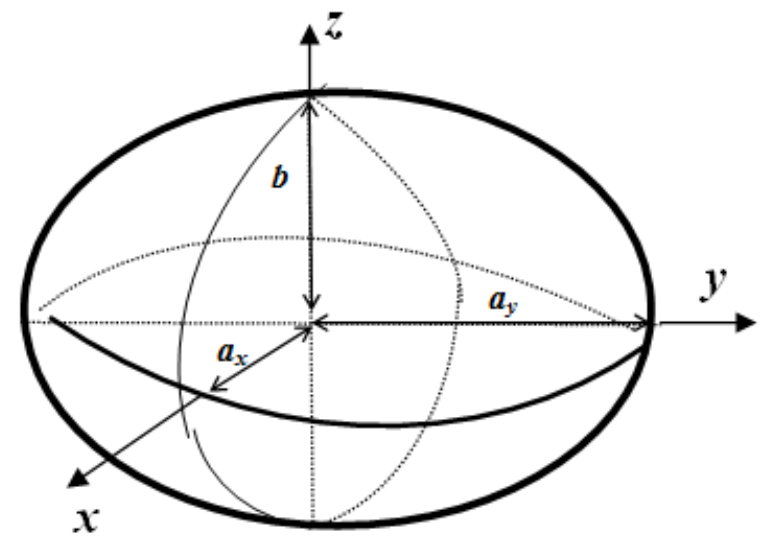

Figure 1: Ellipsoid

Although ellipsoid equation is quite simple and smooth, computations are quite difficult on the ellipsoid. The main reason for this difficulty is the lack of symmetry. Generally, an ellipsoid is defined with 9 parameters. These parameters are; 3 coordinates of center $\left(\mathrm{X}_{\mathrm{o}}, \mathrm{Y}_{\mathrm{o}}, \mathrm{Z}_{\mathrm{o}}\right), 3$ semi-axes $\left(\mathrm{a}_{\mathrm{x}}, \mathrm{a}_{\mathrm{y}}, \mathrm{b}\right)$ and 3 rotational angles $(\varepsilon, \psi, \omega)$ which represent rotations around $\mathrm{x}-, \mathrm{y}-$ and $\mathrm{z}-$ axes respectively in Figure 2. These angles control the orientation of the ellipsoid.

$\mathrm{R}_{1}, \mathrm{R}_{2}, \mathrm{R}_{3}$ are plane rotation matrices

$$
\underline{\mathrm{R}}_{1}(\varepsilon)=\left[\begin{array}{ccc}
1 & 0 & 0 \\
0 & \cos \varepsilon & \sin \varepsilon \\
0 & -\sin \varepsilon & \cos \varepsilon
\end{array}\right], \underline{\mathrm{R}}_{2}(\psi)=\left[\begin{array}{ccc}
\cos \psi & 0 & -\sin \psi \\
0 & 1 & 0 \\
\sin \psi & 0 & \cos \psi
\end{array}\right], \underline{\mathrm{R}}_{3}(\omega)=\left[\begin{array}{ccc}
\cos \omega & \sin \omega & 0 \\
-\sin \omega & \cos \omega & 0 \\
0 & 0 & 1
\end{array}\right] \text { (2) }
$$

$\mathrm{R}$-rotation matrix is obtained from $\mathrm{R}_{1}, \mathrm{R}_{2}, \mathrm{R}_{3}$ by multiplying the reverse order

$$
\begin{aligned}
& \underline{R}=\underline{R}_{3}(\omega) \underline{R}_{2}(\psi) \underline{R}_{1}(\varepsilon) \\
& \underline{R}=\left[\begin{array}{ccc}
\cos \psi \cos \omega & \cos \varepsilon \sin \omega+\sin \approx \sin \psi \cos \omega & \sin \sigma \sin \omega-\cos \varepsilon \sin \psi \cos \omega \\
-\cos \psi \sin \omega & \cos \varepsilon \cos \omega-\sin \approx \sin \psi \sin \omega & \sin \varepsilon \cos \omega+\cos \approx \sin \psi \sin \omega \\
\sin \psi & -\sin \approx \cos \psi & \cos \varepsilon \cos \psi
\end{array}\right]
\end{aligned}
$$




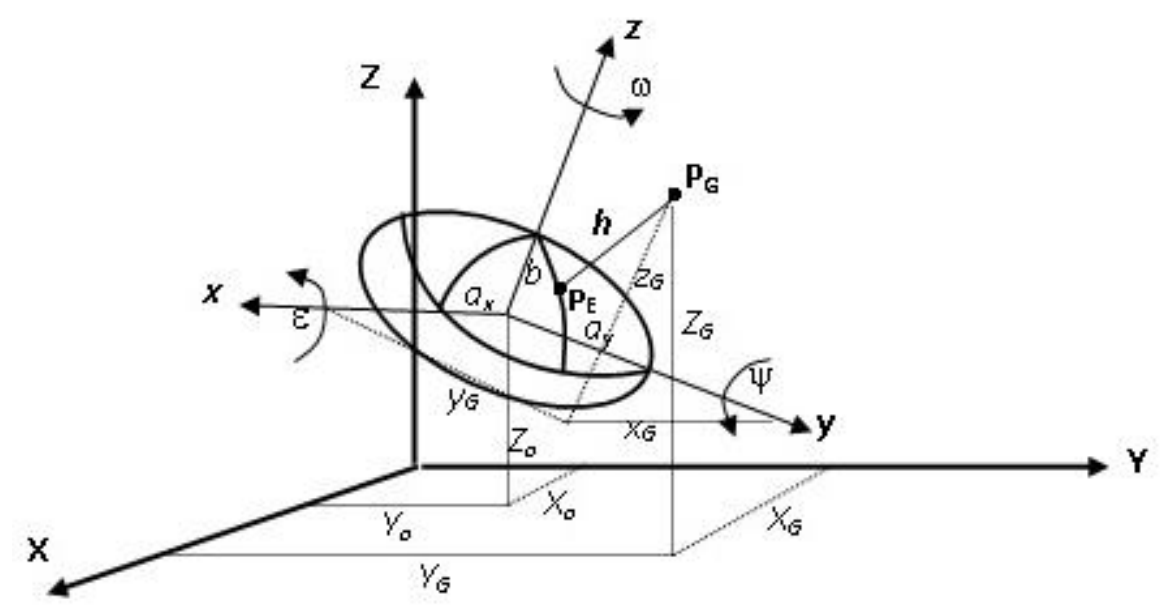

Figure 2: Shifted - oriented ellipsoid

\section{FITTING ELLIPSOID}

For the solution of the fitting problem, the linear or linearized relationship, written between the given data points and unknown parameters (one equation per data points), consists of equations, including unknown parameters.

$$
A_{n, u} \cdot \delta x_{u}=l_{n}
$$

Here, $A$ is design matrix, $\delta x$ is unknown parameters, lis measurements vector or data points,

For this minimization problem to have a unique solution the necessary conditions is to be $n>=9$ and the data points lie in general position (e.g., not all data points should lie is an elliptic plane). Throughout this paper, we assume that these conditions are satisfied.

$u=9$ : number of unknown parameter

$n$ : number of given data point (or measurements)

$f=n-u$ :degree of freedom

-If $f=0$ there is only one (exact) solution, algebraic solution

-If $f<0$ there is no solution. The solutioncan be found with based on the extra constraint

-If $f>0$ is most commonly encountered situation. The given data points (or measurements), which are much greater than the required number cause discrepancy, and in this case, the solution is not unique. There is an over determined system. Because $n>u$, in other words the number of equations is greater than the number of unknowns.

The system of linear equations (3) must be solved. Therefore, this system must be consistent with the rang of design matrix, and design matrix extended with constant terms, must be equal, so that $\operatorname{rang}(A)=\operatorname{rang}(A: l)$; whereas, the system of (3) is inconsistent, because $\delta x$ unknown parameters that provide (3), can not be calculated. In this case, $\operatorname{rang}(A) \leq u$. The extended matrix with $l$ measurements $\operatorname{rang}(A: l)$ is generally more than $\operatorname{rang}(A)$. There is no solution of inconsistent 
equations, and only the approximate solution of the system can be derived. The equation system with approximate solution is calculated by adding $\varepsilon$ residuals (or corrections) at the right side of (3).

$$
A_{n, u} \cdot \delta x_{u}=l_{n}+\varepsilon_{n}
$$

Depending on the choice of $\varepsilon$ residuals vector, infinite solutions can be obtained. The unique solution can be derived only according to an estimator (objective function). For example, the LS always give an unique solution Bektas and Sisman (2010). Here, the question of which estimation method to use comes to mind?

\section{WHICH ESTIMATOR SHOULD BE USED?}

It is hoped that the residuals will be small. The more suitable estimation method is one that creates smaller residuals. It is seen that usually the objective functions are formed based on the minimization of corrections or a function of corrections. There are numerous estimators, some of these are $l_{1}$-norm, $l_{2}$-norm, $l_{p}$-norm, Fair, Huber, Cauchy, German-McClure, Welsch and Tukey. Two estimator methods come to the forefront. The most used estimators are shown below:

(i) $[\varepsilon \varepsilon]=\min .\left(l_{2}\right.$-norm) Least Squares Method (LSM)

(ii) $[\mathrm{I} \varepsilon \mathrm{I}]=\min$. ( $l_{1}$-norm) Least Absolute Values Method (LAVM).

\subsection{The Comparison of $l_{1}$ and $l_{2}$-Norm Methods}

The solution of the $l_{2}$-norm method is always unique, and this solution is easily calculated. The $l_{2}$-norm method is widely used in parameters estimation. The $l_{2}$-norm method has indisputable superiority in parameter estimation.

The disadvantages of the $l_{2}$-norm method are that is affected by outlying (gross errors) and it distributes to the sensitivity measurements. In this case, ellipsoid fitting is a very nice application.

With least-squares techniques, even one or two outliers in a large set can wreak havoc! Outlying data give an effect so strong in the minimization that the parameters thus estimated by those outlying data are distorted. Numerous studies have been conducted, which clearly show that least-squares estimators are vulnerable to the violation of these assumptions. Sometimes, even when the data contains only one bad measurement, $l_{2}$-norm method estimates may be completely perturbed Zhang (1997).

The solution of the $l_{1}$-norm method is not always unique, and there may be several solutions. Also, the solution of the $l_{l}$-norm method is not generally obtained directly, but iteratively calculations are made. Therefore, the solution is not easily calculated like in the $l_{2}$-norm method. Notwithstanding, when the computational tools, computer capacity and speed are considered, the difficulty of calculations are eliminated. The advantages of the $l_{l}$-norm method are nonsensitivity against measurements, including gross errors, and the solution is not or is little affected by these measurements.

The author of this study proposed and used the $l_{2}$-norm method in the solution of parameter estimation (optimization problems, adjustment calculus), after the measurement group cleaned 
up gross and systematic errors using the $l_{1}$-norm method. For further information see Bektas and Sisman (2010).

\section{ALGEBRAIC ELLIPSOID FITTING METHODS}

The general equation of an ellipsoid is given as

$$
A^{\prime} x^{2}+B^{\prime} y^{2}+C^{\prime} z^{2}+2 D^{\prime} x y+2 E^{\prime} x z+2 F^{\prime} y z+2 G^{\prime} x+2 H^{\prime} y+2 I^{\prime} z+K^{\prime}=0
$$

(5) contains ten parameters. In fact, nine of those ten parameters are independent. For example, if all the coefficients in this equation multiply by $\left(-1 / \mathrm{K}^{\prime}\right)$, we get a new equation which contains nine unknown parameters, and its constant term will be equal to "-1".

$$
A x^{2}+B y^{2}+C z^{2}+2 D x y+2 E x z+2 F y z+2 G x+2 H y+2 I z-1=0
$$

In this algorithm, we need to check whether a fitted shape is an ellipsoid. In theory, the conditions that ensure a quadratic surface to be an ellipsoid have been well investigated and explicitly stated in analytic geometry textbooks. An ellipsoid can be degenerated into other kinds of elliptic quadrics, such as an elliptic paraboloid. Therefore, a proper constraint must be added. Li and Griffiths gave the following definitions Li and Griffiths (2004).

$$
\begin{aligned}
& i=A+B+C \\
& j=A B+B C+A C-F^{2}-E^{2}-D^{2}
\end{aligned}
$$

However $4 j-i^{2}>0$ is just a sufficient condition to guarantee that an equation of second degree in three variables represent an ellipsoid, but it is not necessary. In this paper, we assume that these conditions are satisfied.

The algebraic method is a linear problem. It is solving the problem directly and easily. The fitting ellipsoid to a given the data set $\left((x, y, z)_{i}, i=1,2, \ldots, n\right)$, is obtained by the solution in the LS sense of in the following:

$$
\Omega . \mathrm{v}=l
$$

Where

$\Omega_{n x u}=$ Design matrix

$\mathrm{v}_{u}=\left[\begin{array}{llllllllll}A & B & C & D & E & F & G & H & I\end{array}\right]^{\mathrm{T}}$ unknown conic parameters

$l_{n}=\left[\begin{array}{lll}1 & 1 & 1 \ldots .\end{array}\right]^{\mathrm{T}}$ unit vector $:$ right side vector

$i$ th row of the $n \times 9$ matrix $\Omega$

$$
\left[\begin{array}{lllllllll}
x_{i}^{2} & y_{i .}^{2} & z_{i}^{2} & 2 x_{i} y_{i} & 2 x_{i} z_{i} & 2 y_{i} z_{i} & 2 x_{i} & 2 y_{i} & 2 z_{i}
\end{array}\right]
$$

It is solved easily in the LS sense as below 


$$
\mathrm{v}=\left(\Omega^{\mathrm{T}} \Omega\right)^{-1} \Omega^{\mathrm{T}} l
$$

or it is solved easily by MATLAB as below

$$
\mathrm{v}=\left[\begin{array}{llll}
x .{ }^{2} & y .{ }^{2} & z .{ }^{2} & 2 x . * y \cdot 2 x . * z .2 y . * \\
* & * 2 * x & 2 * y & 2 * z
\end{array}\right] \backslash \text { ones(n) }
$$

If there are differences in weights or correlations between given data points, $\mathrm{P}$ weight matrix is added in the solution, and then

$$
\mathrm{v}=\left(\Omega^{\mathrm{T}} \mathrm{P} \Omega\right)^{-1} \Omega^{\mathrm{T}} \mathrm{P} l
$$

$\mathrm{P}=\mathrm{K}_{l l}{ }^{-1} \mathrm{~K}_{l l}: n \mathrm{x} n$ variance-covariance matrix of data points

Residual (or correction) vector is computed as below

$$
\varepsilon=\left[\begin{array}{lllllll}
x^{2} & y .{ }^{2} & z .^{2} & 2 x . y . & 2 x . z .2 y \cdot z . & 2 x \cdot 2 y . & 2 z .
\end{array}\right] \cdot \mathrm{v}-\mathrm{ones}(\mathrm{n})
$$

LS optimization give us $\|\varepsilon\|=\min$.

Algebraic methods all have indisputable advantages of solving linear LS problems. The methods for this are well known and fast. However, it is intuitively unclear what it is we are minimizing geometrically in (6) is often referred to as the "algebraic distance" to be minimized Ray and Srivastava (2008). A geometric interpretation given by Bookstein (1979) clearly demonstrates that algebraic methods neglect points far from the center.

\section{FITTING OF ELLIPSOID USING ORTHOGONAL DISTANCES}

To overcome the problems with the algebraic distances, it is natural to replace them by the orthogonal distances which are invariant to transformations in Euclidean space and which do not exhibit the high curvature bias. An ellipsoid of best fit in the LS sense to the given data points can be found by minimizing the sum of the squares of the geometric distances from the data to the ellipsoid. The geometric distance is defined to be the distance between a data point and its closest point on the ellipsoid.

Determining best fit ellipsoid is a nonlinear least squares problem which in principle can be solved by using the Levenberg-Marquardt (LM)algorithm. Generally, non-linear least squares is a complicated issue. It is very difficult to develop methods which can find the global minimizer with certainty in this situation. When a local minimizer has been discovered, we do not know whether it is a global minimizer or one of the local minimizer Zisserman (2013).

There are a variety of nonlinear optimization techniques. Such as Newton, Gauss-Newton, Gradient Descent, Levenberg-Marquardt approximation etc.However, these fitting techniques involve a highly nonlinear optimization procedure, which often stops at a local minimum and cannot guarantee an optimal solution Li and Griffiths (2004).

Away from the minimum, in regions of negative curvature, the Gauss-Newton approximation is not very good. In such regions, a simple steepest-descent step is probably the best plan. The Levenberg-Marquardt method is a mechanism for varying between steepest-descent and GaussNewton steps depending on how good the $\mathrm{H}_{\mathrm{GN}}$ approximation is locally. 
The Levenberg-Marquardt method uses the modified Hessian

$\mathrm{H}(\mathrm{x}, \lambda)=\mathrm{H}_{\mathrm{GN}}+\lambda . \mathrm{I}(\mathrm{I}$ : identity matrix $)$

- When $\lambda$ is small, H approximates the Gauss-Newton Hessian.

- When $\lambda$ is large, $\mathrm{H}$ is close to the identity, causing steepest-descent steps to be taken.

This algorithm does not require explicit line searches. More iterations than Gauss-Newton, but, no line search required, and more frequently converge suppose that we have a unknowns parameter set

$v=\left[\begin{array}{lllllllll}A & B & C & D & E & F & G & H & I\end{array}\right]^{\mathrm{T}}$ are unknown conic parameters. The general conic equation for an ellipsoid is given as (6)

We will reach the solution by establishing relationships between variations in the conical coefficients and the orthogonal distances.

The initial parameters were derived from the algebraic fitting ellipsoid.

$$
\begin{aligned}
&\left(\begin{array}{lll}
\mathrm{x}_{\mathrm{i}}^{\mathrm{e}} & \mathrm{y}_{\mathrm{i}}^{\mathrm{e}} & \mathrm{Z}_{\mathrm{i}}^{\mathrm{e}}
\end{array}\right): \text { Projection coordinates (onto ellipsoid) of given } \mathrm{P}_{\mathrm{i}} \text { data points } \\
& \mathrm{K}=\left[\begin{array}{llllll}
\boldsymbol{x}_{i}^{e} & \boldsymbol{y}_{i}^{e} & \boldsymbol{z}_{i}^{e} & 1
\end{array}\right] \\
& d u=2 . \mathrm{K} \cdot\left[\begin{array}{lllll}
\mathrm{A} & \mathrm{D} & \mathrm{E} & \mathrm{G}
\end{array}\right]^{\mathrm{T}}: \partial / \partial \mathrm{x} \text { partial derivative with respect to } \mathrm{x} \text { - coor.(16) } \\
& d v=2 . \mathrm{K} \cdot\left[\begin{array}{lllll}
\mathrm{D} & \mathrm{B} & \mathrm{F} & \mathrm{H}
\end{array}\right]^{\mathrm{T}}: \partial / \partial \mathrm{y} \text { partial derivative with respect to } \mathrm{y} \text { - coor.(17) } \\
& d w=2 . \mathrm{K} \cdot\left[\begin{array}{llll}
\mathrm{E} & \mathrm{F} & \mathrm{C} & \mathrm{I}
\end{array}\right]^{\mathrm{T}} \quad: \partial / \partial \mathrm{z} \text { partial derivative with respect to } \mathrm{z} \text { - coor.(18) } \\
& e=\left(d u^{2}+d v^{2}+d w^{2}\right)^{3 / 2}
\end{aligned}
$$

$i$ th row of the $n \times 10$ matrix $J$ (jakobien matrix)

$$
(1 / e)\left[\begin{array}{llllllllll}
x_{i}^{2} & y_{i .}{ }^{2} & z_{i}{ }^{2} & 2 x_{i} y_{i} & 2 x_{i} z_{i} & 2 y_{i} z_{i} & 2 x_{i} & 2 y_{i} & 2 z_{i} & -1
\end{array}\right]
$$

$i$ th row of the right side vector $h_{n x 1}$

$$
h_{i}=\operatorname{sign}\left(\mathrm{z}_{\mathrm{i}}^{\mathrm{e}}-\mathrm{z}_{\mathrm{i}}\right) \cdot \operatorname{sign}\left(\mathrm{z}_{\mathrm{i}}^{\mathrm{e}}\right) \sqrt{\left(x_{\mathrm{i}}^{\mathrm{e}}-\mathrm{x}_{\mathrm{i}}\right)^{2}+\left(y_{\mathrm{i}}^{\mathrm{e}}-\mathrm{y}_{\mathrm{i}}\right)^{2}+\left(\mathrm{z}_{\mathrm{i}}^{\mathrm{e}}-\mathrm{z}_{\mathrm{i}}\right)^{2}}
$$

We obtained the below linearized equation

$$
J_{n \times 10 .} d v_{n \times I}=h_{n \times I}
$$

$$
d v=\left[\begin{array}{lll}
d A & d B & d C d D d E d F d G d H d I
\end{array}\right]^{\mathrm{T}}
$$

The fitted orthogonal ellipsoid is obtained by the solution in the LS sense with the L-M algorithm.

\subsection{The Levenberg-Marquardt Algorithm}

1-Solve algebraic methods and find initial values for $v$

$$
\text { set } \lambda=1 \text { (say) }
$$

2- Compute $J$-jacobien matrix and $h_{i}$ orthogonal distances from all given data points 


$$
\operatorname{minh}=h^{T} h
$$

3- Solve $\left(J^{T} J+\lambda I\right) d v=J^{T} h$

$v=v+d v$, new conic parameter

Find again $h_{i}$ orthogonal distances from all given data points

$$
\text { newh }=h^{T} h
$$

4- ifnewh $<\operatorname{minh} \%$ yes there is improvement, reduce $\lambda$

$$
\begin{aligned}
& \operatorname{minh}=\text { newh } ; \lambda=\lambda / 2 \\
& \text { goto } 3
\end{aligned}
$$

else \% no improvement, increase $\lambda$

$$
\begin{aligned}
& \lambda=2 * \lambda \\
& \text { goto } 3
\end{aligned}
$$

end

\subsection{Finding Orthogonal Distances from the Ellipsoid}

In this paper, we present techniques for ellipsoid fitting which are based on minimizing the sum of the squares of the geometric distances between the data and the ellipsoid. The most timeconsuming part is the computation of the orthogonal distances between each point and the

\begin{tabular}{|c|c|c|c|c|c|c|c|c|c|c|}
\hline $\mathrm{x}:[\mathrm{c} 7$ & 7 & 9 & 9 & 11 & 11 & 8 & 8 & 10 & 10 & 12 \\
\hline y: [22 & 19 & 23 & 19 & 24 & 20 & 21 & 17 & 22 & 18 & 23 \\
\hline : [31 & 28 & 31 & 27 & 29 & 26 & 32 & 29 & 32 & 28 & 31 \\
\hline
\end{tabular}
ellipsoid. Our aim to find the orthogonal distances from a shifted-oriented ellipsoid see Figure 2. For detailed information on this subject refer to Bektas (2014).

\section{NUMERICAL EXAMPLE}

For numerical applications 12 triplets $(\mathrm{x}, \mathrm{y}, \mathrm{z})$ cartesian coordinates were produced.

Here data points coordinates,

This problem is also solved by Least Absolute Values Method $\left(l_{1}\right.$-norm $)$ and the following results were obtained.

The conical coefficients in the Least Squares Method is,

$v=\left[\begin{array}{lllllllll}-0.0006 & -0.0008 & -0.0010 & 0.0005 & -0.0005 & 0.0003 & 0.0092 & 0.0050 & 0.0278\end{array}\right]$

The conical coefficients in the Least Absolute Values Method is,

$v=\left[\begin{array}{lllllllll}-0.0071 & -0.0084 & -0.0096 & 0.0047 & -0.0040 & 0.0023 & 0.0880 & 0.0061 & 0.0271\end{array}\right]$

We show both the algebraic and orthogonal fitting results are as shown in Table-1.

Bol. Ciênc. Geod., sec. Artigos, Curitiba, v. 21, no 2, p.329-339, abr-jun, 2015. 
Table-1: The result of algebraic and orthogonal fitting ellipsoid

\begin{tabular}{|c|c|c|c|c|c|c|c|c|c|}
\hline \multicolumn{10}{|c|}{ Algebraic fitting } \\
\hline \multicolumn{3}{|c|}{ Center of Coordinates } & \multicolumn{3}{|c|}{ Semi-axes } & \multicolumn{3}{|c|}{$\begin{array}{l}\text { Rotational angles } \\
\text { (degree) }\end{array}$} & \multirow[t]{2}{*}{ RSS* } \\
\hline$x_{o}$ & $y_{o}$ & zo & $\boldsymbol{a}_{x}$ & $a_{y}$ & $\boldsymbol{b}$ & $\varepsilon$ & $\Psi$ & $\omega$ & \\
\hline 10.384 & 20.965 & 29.007 & 7.468 & 3.164 & 2.830 & 47.98 & 18.68 & 28.21 & 0.216 \\
\hline
\end{tabular}

Orthogonal fitting (after four iterations)

\begin{tabular}{l|l|l|l|l|l|l|l|l|l}
\hline 11.785 & 21.694 & 28.492 & 11.188 & 3.346 & 1.789 & 47.20 & 17.03 & 27.73 & 0.189 \\
\hline
\end{tabular}

*RSS: The residual sum of squares of the orthogonal distances

\section{DISCUSSION}

Orthogonal least-squares has a much sounder basis, but is usually difficult to implement. Why are algebraic distances usually not satisfactory? The big advantage of use of algebraic distances is the gain in computational efficiency, because closed-form solutions can usually be obtained. In general, however, the results are not satisfactory.The function to minimize is usually not invariant under Euclidean transformations. For example, the function with normalization $\mathrm{K}^{\prime}$ = 1 in (5) is not invariant with respect to translations. This is a feature we dislike, because we usually do not know in practice where the best coordinate system to represent the data is. A point may contribute differently to the parameter estimation depending on its position on the conic. If a priori all points are corrupted by the same amount of noise, it is desirable for them to contribute the same way Zhang (1997). More importantly, algebraic methods have an inherent curvature bias - data corrupted by the same amount of noise will misfit unequally at different curvatures Ray and Srivastava (2008). Our experience tells us that if the coordinates of given points consists of a large number this will cause bad condition. Therefore, before fitting, you must shift the given coordinates to the center of gravity, after fitting operation the coordinates of ellipsoid's center must be shifted back to the previous position.

\section{CONCLUSION}

In this paper, we studied on the orthogonal fitting ellipsoid. The problem offitting ellipsoid is encounteredfrequently intheimage processing, face recognition, computer games, geodesydeterminingmore realistic Earth ellipsoid etc. The paper has presented a new method of orthogonal fitting ellipsoid. The new method relies on solving an over determined system of nonlinear equations with the use of the L-M method. In conclusion, the presented method may be considered as fast, accurate and reliable and may be successfully used in other areas. The presented orthogonal fitting algorithm can be applied easily to biaxial ellipsoid, sphere and also other surfaces such as paraboloid, hyperboloid,etc. 


\section{REFERENCES}

Bektas, S., Sisman, Y. The comparison of L1 and L2-norm minimization methods, International Journal of the Physical Sciences, 5(11), 1721 - 1727, 2010

Bektas, S. "Orthogonal Distance From An Ellipsoid, Boletim de CienciasGeodesicas, Vol. 20, No. 4 ISSN 1982-2170 , http://dx.doi.org/10.1590/S1982-217020140004000400053 (in Press), 2014

Bookstein, F. L. Fitting conic sections to scattered data", Computer Graphics and Image Processing 9,56-71, 1979.

Burša M, Šima Z. Tri-axiality of the Earth, the Moon and Mars, Stud. Geoph.etGeod. 24(3):211217, 1980.

Eberly, D. Least Squares Fitting of Data", Geometric Tools, LLC, http://www.geometrictools.com, 2008.

Feltens, J. Vector method to compute the Cartesian $(X, Y, Z)$ to geodetic $(\varphi, \lambda, h)$ transformation on a triaxial ellipsoid", Journal of Geod. 83:129-137, 2009.

İz, H. B., Ding X. L., Dai C. L.,Shum C. K. Polyaxial figures of the Moon, J. Geod. Sci., 1, 348354, 2011.

Li, Q., Griffiths J.G. Least Squares Ellipsoid Specific Fitting, Proceedings of the Geometric Modelling and Processing (GMP'04), 2004.

Ligas, M. Cartesian to geodetic coordinates conversion on a triaxial ellipsoid, Journal of Geod., 86, 249-256, 2012.

Ray, A., Srivastava D.C. Non-linear least squares ellipse fitting using the genetic algorithm with applications to strain analysis, Journal of Structural Geology 30 1593-1602. 2008.

Turner, D.A., Anderson I. J., Mason J.C., Cox, M.G. An algorithm for fitting an ellipsoid to data, Cite-dataseerXBeta, http://citeseerx.ist.psu.edu/viewdoc/summary? doi=10.1.1.36.2773, 1999.

Zhang, Z. Parameter estimation techniques: a tutorial with application to conic fitting, Image and Vision Computing 15,59-76, 1997.

Zisserman, A. C25 Optimization, 8 Lectures, Hilary Term 2013,2 Tutorial Sheets,Lectures 3-6 (BK), 2013.

(Recebido em dezembro de 2014. Aceito em janeiro de 2015). 


\title{
A SPATIAL DECISION SUPPORT SYSTEM FOR ECOTOURISM DEVELOPMENT IN CASPIAN HYRCANIAN MIXED FORESTS ECOREGION
}

Sistema de suporte a decisão espacial para o desenvolvimento de ecoturismo em regiões de florestas mistas caspian hyrcanian

\author{
ALI BALI ${ }^{1}$ \\ SEYED MASOUD MONAVARI ${ }^{1}$ \\ BORHAN RIAZI ${ }^{1}$ \\ NEMATOLLAH KHORASANI ${ }^{1}$ \\ MIR MASOUD KHEIRKHAH ZARKESH ${ }^{1}$ \\ ${ }^{1}$ Department of the Environmental Science \\ Faculty of the Environment and Energy \\ Tehran Science and Research Branch \\ Islamic Azad University - Tehran - Iran \\ Email: monavarism@yahoo.com;
}

\begin{abstract}
:
Ecotourism, as a form of sustainable nature-based tourism, promotes conservation of ecological and scenic values. In this study, a Spatial Decision Support System, SDSS, was developed based upon Multi Criteria Evaluation, MCE, for ecotourism development in the Caspian Hyrcanian Mixed Forests ecoregion, northern Iran. For this, important criteria and constraints for ecotourism development were shortlisted using the Delphi Method. The criteria were weighted using Analytical Hierarchy Process, AHP. The obtained results indicated that "distance from water resources", "land use", "slope", "soil", "climate", "distance from roads", "land cover density", "erosion", and "distance from residential areas" were the most important criteria, respectively. The findings suggest that GIS-based SDSS is suitable to engage the various criteria affecting the development of ecotourism destinations. This empirical research develops a new method that can significantly facilitate planning forecotourism development with respect to ecological capability of ecotourism destinations.
\end{abstract}

Keywords: Ecotourism; GIS; Decision Support System; AHP; Anzali Watershed.

\section{Resumo:}

Ecoturismo, como forma de turismo sustentável baseado na natureza promove conservação de valores ecológicos e cênicos. Neste estudo, o Sistema Espacial de Suporte a Decisões, SDSS, foi 
desenvolvido com base na Avaliação Multi-Critério, MCE, para o desenvolvimento de ecoturismo na ecoregião de florestas mistas caspian hyrcanian, no norte do Irã. Para isto, critérios importantes e restrições para o desenvolvimento do ecoturismo foram listados usando o Método Delphi. Os critérios foram analisados ponderadamente usando o Processo de Hierarquia Analítica, AHP. Os resultados obtidos indicaram que: "distância de fontes de água", "uso da terra", inclinação do terreno", "solo", "clima", "distância das estradas", "densidade de cobertura vegetal", "erosão", e "distância de áreas residenciais", foram os critérios, respectivamente, mais importantes. Os resultados sugerem que o SIG baseado no SDSS é adequado para engajar-se a vários critérios afetando o desenvolvimento dos destinos do ecoturismo. Esta pesquisa empírica desenvolve um novo método que pode facilitar o planejamento para o desenvolvimento do ecoturismo que diz respeito à capacidade ecológica dos destinos ecoturísticos.

Palavras-chave: Ecoturismo; GIS; Sistema de Suporte de Decisão; AHP; Bacia Hidrográfica Anzali.

\section{INTRODUCTION}

The ecotourism term was initially used to describe nature-based traveling for research, and recreational purposes, with special emphasis on conservation of ecological values (CeballosLascurain, 1996; Culbertson et al., 1994). Ecotourism is composed of two words "eco" and "tourism" (Anomasiri, 2004). The concept promotes conservation of ecological and scenic values of tourist destinations (Boyd and Butler, 1993; Lindberg and Mckercher, 1997). In other words, ecotourism must provide a balance between traveling in the nature and conservation of ecosystem values (Dhammapitaka and Payuto, 2000; Weaver, 2001; Leksakundilok, 2004). It also emphasizes on cultural exchange between natives and tourists (Saaty and Vargas, 2001; Mendoza and Prabhu, 2006).

Sustainable tourism entails thestudy oftourism activities and ecological capacities, as well as balancing the interest of stakeholders (Ok, 2006). The strategies for sustainable tourism development should be presented in the form of a management plan to minimize damages to the environment (Lindberg and Mckercher, 1997).

AHP method was developed by Saaty in 1980 as a tool for Multi Criteria Decision Making (MCDM) (Saaty, 1980). AHP is a useful method for identification and prioritization of criteria for various purposes (Mendoza and Prabhu, 2006; Sharpley, 2006). AHP has been used widely in different fields by researchers worldwide (Vaidya and Kumar, 2006). The purpose of MCDM methods is to help decision-makers solve complex decision-making issues (Vaidya and Kumar, 2006). MCDM includes the steps of identification, weighting, and prioritization of criteria (Malczewski, 2004).

GIS is a SDSS tool that has broadly been used in tourism studies (Babaie-Kafaky, 2009). GIS could facilitate preparing the maps of natural resources (Gul, 2006). it has been used for data processing in the different fields of geomorphologic and pedological studies, land evaluation, site selection, land use planning, etc. (Culbertson, 1994).

Several criteria have been used for site selection of ecotourism destinations, including plant density, flora, fauna, plant biodiversity, fragile habitats, water quality, wildlife species, land cover, and many others (Boyd et al.,1995; Bunruamkaew and Murayam ,2011). Boyd et al. (1995) reported that environmental characteristics, income, responsibility, and socio-economic property are of important criteria for ecotourism development. Boyd and Butler in 1993 studied

Bol. Ciênc. Geod., sec. Artigos, Curitiba, v. 21, no 2, p.340-353, abr-jun, 2015. 
ecotourism potentials of Northern Ontarian using the criteria of cultural characteristics, landscape, wildlife species, natural resources, and local communities (Boyd and Butler, 1993). OK in 2006 developed a MCDM model based on ELECTRE method, consisting of 28 alternatives and a total number of 19 criteria (e.g. horse-riding, shooting, and sportive fishing) for ecotourism management in Uganda. Kumari et al. (2010) combined five indices including Wildlife Distribution Index (WDI), Ecological Value Index (EVI), Ecotourism Attractively Index (EAI), Environmental Resiliency Index (ERI), and Ecotourism Diversity Index (EDI) to identify and prioritize the potential ecotourism sites in the West District of Sikkim state, India.

The present study was conducted to develop a simple SDSS model based on AHP, Fuzzy, and GIS for optimized ecotourism site selection in the Caspian Hyrcanian Mixed Forests ecoregion.

\section{METHODS AND MATERIALS}

\subsection{Study Area}

Anzali is the most important and environmentally sensitive watershed in northern Iran situated between the longitudes $48^{\circ} 45^{\prime}-49^{\circ} 42^{\prime} \mathrm{E}$ and the latitudes $36^{\circ} 55^{\prime}-37^{\circ} 32^{\prime} \mathrm{N}$ (Figure 1), over an area of $1800 \mathrm{~km}^{2}$ (Jica, 2005). As a part of the Caspian Hyrcanian Mixed Forests ecoregion, the watershed is of popular tourist destinations in Iran. Maximum and minimum heights are found at the altitude of $3100 \mathrm{~m}$ in the south and $-28 \mathrm{~m}$ in northern coast of the Caspian Sea. It is divided by two main landforms; a flat area; low-lying plain in the north, and a mountainous area in the south. The plain, with altitude height of less than $100 \mathrm{~m}$, is mainly covered by paddy fields and orchards (Jica, 2005). Anzali has been registered as an international wetland in the 1975 Ramsar Convention. It provides habitats for migrating birds. The climatic condition of the watershed is humid to very humid, with an annual rainfall of approximately between $400 \mathrm{~mm}$ and $2000 \mathrm{~mm}$ and a tempering temperature ranging from $-0.8^{\circ} \mathrm{C}$ to $37^{\circ} \mathrm{C} ; 17^{\circ} \mathrm{C}$ on an annual average (Jica, 2012). The soils of the watershed are of two types "mountainous soils" and "plain soils". The mountainous soils covered by entisols and cambisoil containing mollic and ochric (buried) epipedons while plain soils are of gleysols and gleyicluvisols types.

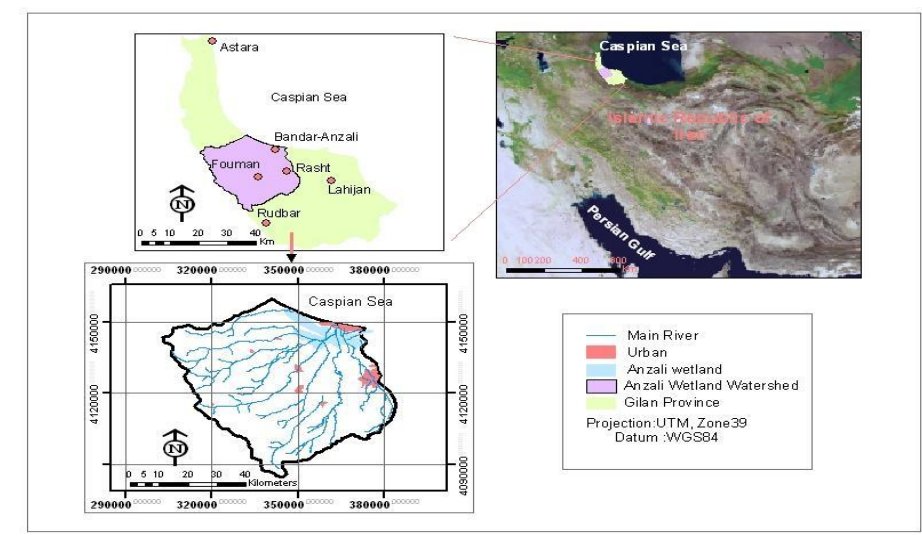

Figure 1: Location of Anzali Watershed in Gilan Province and in Iran. 


\subsection{Research Procedure}

\subsubsection{Data Collection}

In this research, data were collected using field surveys, questionnaires, and literature reviews (Table 1). As an initial step, an inventory of criteria affecting ecotourism development in the study area was prepared. The questionnaires were placed at the disposal of Delphi panelists. The panelists were experts with at least five years of relevant experience in the field of tourism affairs. At the first round of Delphi, the questionnaires were distributed among a total number of 20 respondents. They were asked to score the criteria using a five-point Likert scale. Excluding lessimportant criteria, the former list was shortlisted. Consensus on the importance of criteria was achieved at the third round. After identification of site selection criteria, the relevant map layers were prepared using Arc GIS 10.1 and Global Positioning System (GPS). Criteria are of two types; factors and constraints. A factor is a criterion that enhances up or detracts from the suitability of a specific alternative for a considered activity. A constraint serves to limit the alternatives and classify the areas into two classes of unsuitable (value 0 ) or suitable (value 1) (Boolean Logic) (Zaredar et al., 2010). All map layers were transferred into the same coordinate system of UTM, zone39N.

Table 1: List and sources of data collected.

\begin{tabular}{c|c|c}
\hline Data & Scale & Source \\
\hline Anzali wetland & $1: 25000$ & Department of Environment \\
\hline Land use/ Cover map, 20 & $1: 50000$ & Satellites Images \\
\hline DEM & $1: 25000$ & National Cartographic Center \\
\hline Tourist map & $1: 50000$ & $\begin{array}{c}\text { Cultural Heritage, Handcrafts and Tourism } \\
\text { Organization }\end{array}$ \\
\hline Protected areas & $1: 25000$ & Department of Environment \\
\hline Roads and infrastructure & $1: 25000$ & Minister of Road and Urban Development \\
\hline Water resources & $1: 25000$ & Ministry of Power \\
\hline Geology/fault/landslide & $1: 100000$ & Organization of Geology
\end{tabular}

\subsubsection{AHP Method}

AHP is one of the commonly-used MCDM techniques (Saaty, 1980; Saaty and Vargas, 2001). It is used to formalize decision-making problems when there are a limited number of choices available, each of which with several attributes. AHP is a method to derive ratio scales from pairwise comparisons (Saaty, 1980). Selecting appropriate criteria is a crucial task in MCE (Saaty and Vargas, 2001). In this research, MCE criteria were selected by literature reviews, field studies, and questionnaires. Selected criteria were weighted using pair wise ranking method developed by Saaty in 1980. In this research, Delphi panelists were asked to give priority to the shortlisted criteria using a 9-pint weighting scale presented by Saaty (Table 2). The scale values vary from 1 that indicates equal preference of criteria in the pair wise comparison matrix to 9 represented extremely preference of criteria in the pair wise comparison matrix. At final step, weighting accuracy was checked by Consistency Ratio (CR). The CR value less than 0.1 confirms accuracy of given weights otherwise weighting process must be repeated (Saaty, 1980). 
In this research, the expert panelists were polled twice; once for short-listing of the initial inventory of ecotourism criteria, and again for weighting and prioritizing of the shortlisted criteria.

Table 2: A nine-point scale for pairwise comparisons, AHP Method.

\begin{tabular}{c|c}
\hline Scale & Degree of preference \\
\hline 1 & Equal importance \\
\hline 3 & Moderate importance \\
\hline 5 & Strong importance \\
\hline 7 & Very strong importance \\
\hline 9 & Extreme importance \\
\hline $2,4,6$ and 8 & Intermediate values \\
\hline
\end{tabular}

\subsubsection{Preparation of Map Layers}

According to the panelists, "soil", "distance from water resources", "land use", "distance from residential areas", "slope", "distance from roads", "land cover density", "erosion", "climate", and "aspect" were recognized as the most important criteria affecting ecotourism development in the study area. The slope map was prepared from topographic map. The aspect map was derived from Digital Elevation Model (DEM) with a pixel size of $25 \mathrm{~m}$. The climatic data were obtained from Metrological Organization of Iran. As important factors on health and safety of tourists, the maps of erosion, faults, and flood zones were prepared from Iranian Organization of Geology. Soil types, which play a critical role in land suitability for ecotourism development, were categorized based on the classification presented by FAO (FAO, 1974). Land use map of the watershed was prepared from IRS satellite images dating back to 2007 on which, different land uses of farmlands, wetlands, woodland, coastal areas, and fragile ecosystems such as wildlife corridors and habitats were specified. It is worth mentioning that highly dense forest or rangeland areas were considered as constraints and excluded from candidate areas for ecotourism development. These areas were dedicated to nature protection. "Distance from roads" and "distance from water resources" were considered as two economic criteria for ecotourism development in the study area.

\subsubsection{Running of SDSS Model}

Map layers are expressed in various measuring scale e.g. slope map in percent (\%), elevation map in meter $(\mathrm{m})$. Thereby, in order to compare criteria maps with each other, all values should be standardized and transformed into the same measurement unit (Kheirkhah Zarkesh et al. 2010). In this research, the map layers were standardized using fuzzy logic based on a value set of between 0 and 1 or 0 and 255 and as well as membership functions (Equations 1 and 2).

$$
x_{I}=\frac{\left(R-R_{\min }\right)}{\left(R_{\max }-R_{\min }\right)} * 255
$$

Where;

$\mathrm{Xi}=$ dimensionless value in a positive or increasing state (in 0-255 range)

$\mathrm{R}=$ initial value

$\mathrm{R} \max =$ maximum value

$\mathrm{R}$ min $=$ minimum value 


$$
X_{I}=\frac{\left(R_{\max }-R\right)}{\left(R_{\max }-R_{\min }\right)} * 255
$$

$\mathrm{Xi}=$ dimensionless value in a negative or decreasing state (in 0-255 range)

After the standardization step, AHP method was used to weight and rank the ecotourism criteria using IDRISI software (Saaty and Vargas, 2001; Malczewski, 2004). Simultaneously, consistency ratio of weights was check to ensure that all of the judgments are consistent. At final step, the weighted map layers were overlaid using Weighed Linear Combination (WLC) method in order to determine suitable areas for ecotourism development in the study area.

Table 3: Upper and lower constraint values of ecotourism criteria.

\begin{tabular}{|c|c|}
\hline Factors & Criteria definition \\
\hline \multirow{3}{*}{ Aspect } & Favorable: Flat, east in summer, south in winter \\
\hline & Intermediate: north in summer, west in winter \\
\hline & $\begin{array}{l}\text { Unfavorable: south and west in summer and spring, } \\
\text { east and north in winter }\end{array}$ \\
\hline \multirow{3}{*}{ Climate (temperature) } & Favorable: ${ }^{\circ} 5-25^{\circ}$ \\
\hline & Intermediate: $25^{\circ}-37^{\circ}$ \\
\hline & Unfavorable: $<5^{\circ}$ and $>37^{\circ}$ \\
\hline \multirow{3}{*}{ Erosion } & Favorable: little \\
\hline & Intermediate : low, moderate \\
\hline & Unfavorable: high, very high \\
\hline \multirow{3}{*}{ Land cover density } & Favorable: $40-70 \%$ \\
\hline & Intermediate :0 - 40\% \\
\hline & Unfavorable: $<40 \%$ \\
\hline \multirow{3}{*}{ Slope } & Favorable: $0-10 \%$ \\
\hline & Intermediate : $10-45 \%$ \\
\hline & Unfavorable: $>45 \%$ \\
\hline \multirow{3}{*}{ Distance from roads } & Favorable: $76-500 \mathrm{~m}$ \\
\hline & Intermediate $: 500-1000 \mathrm{~m}$ \\
\hline & Unfavorable: $<76 \mathrm{~m}$ and $>1000 \mathrm{~m}$ \\
\hline \multirow{3}{*}{$\begin{array}{l}\text { Distance from water } \\
\text { resources }\end{array}$} & Favorable: $50-500 \mathrm{~m}$ \\
\hline & Intermediate $: 500-1000 \mathrm{~m}$ \\
\hline & Unfavorable: $0-50 \mathrm{~m}$ and $>1000 \mathrm{~m}$ \\
\hline \multirow{3}{*}{ Land use } & Favorable: parts of Anzali Wetland, forest and coastal areas \\
\hline & Intermediate : others, except unfavorable \\
\hline & $\begin{array}{l}\text { Unfavorable: irrigated farming, urban areas,landslide, } \\
\text { fragile ecosystems and flood zones }\end{array}$ \\
\hline \multirow{3}{*}{ Soil (Texture) } & Favorable: loamy \\
\hline & Intermediate : sandy-loam, loamy-sandy \\
\hline & Unfavorable: heavy \\
\hline \multirow{3}{*}{$\begin{array}{l}\text { Distance from } \\
\text { residential aras }\end{array}$} & Favorable:500 -5000 m \\
\hline & Intermediate $: 500-2000 \mathrm{~m}$ \\
\hline & Unfavorable: residential areas a height of $>5000 \mathrm{~m}$ \\
\hline
\end{tabular}


$\sum w_{i} x_{i} \Pi c_{j}=\mathrm{S}(3)$

Where, $\mathrm{S}=$ suitability degree; $w_{\mathrm{i}}=$ the weight of the factor $I ; x_{i}=$ dimensionless value of the factor I; $c_{j}=$ constraint map; $\Pi=$ multiply mark.

Research procedure is depicted in Figure 2.

Figure 2: Research procedure.

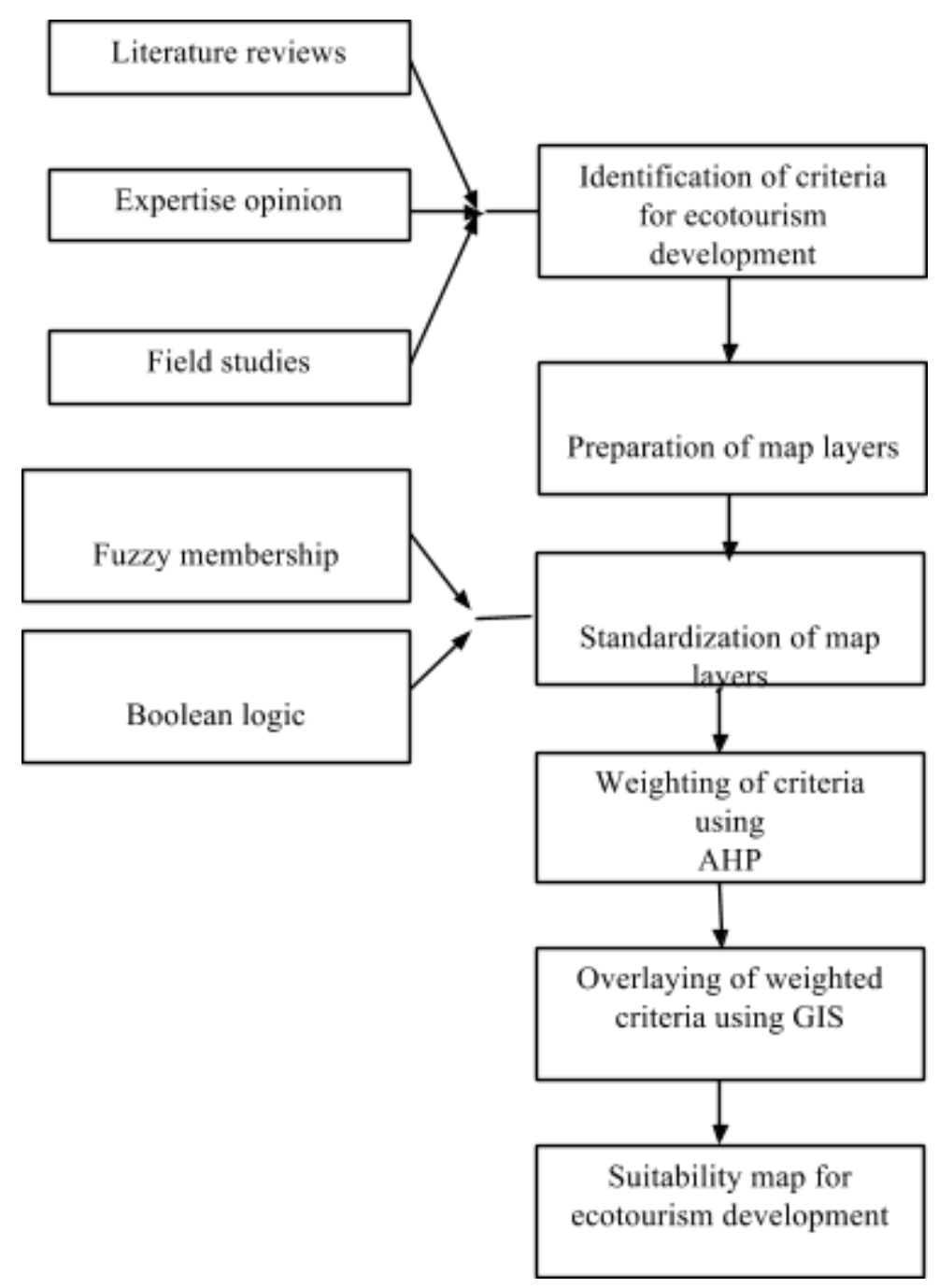

3. RESULTS AND DISCUSSION

Figure 3 shows distribution of different land uses in Anzali Watershed. As the figure demonstrates, irrigated farming, woodlands, and Anzali Wetland cover 143836ha (40\%), 137310ha (38\%), and13647ha (4\%) of the total study area, respectively. 


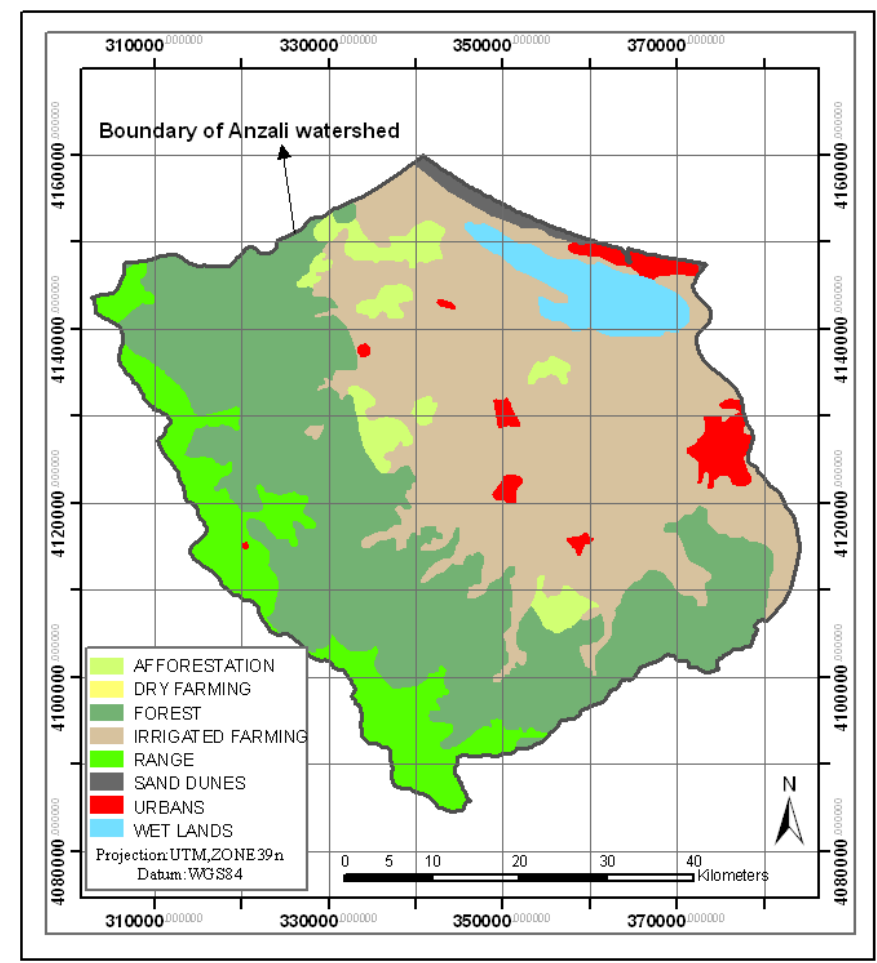

Figure 3: Different land uses in Anzali Wetland.

In this research, landslides, faults, fragile ecosystems, flood zones, irrigated fields, steep areas with a slope of more than $45 \%$, land cover with a density of higher than $70 \%$ were considered as a constrain map and excluded from the study area (Figure 4). These areas are not suitable for ecotourism development.

Figure 5 illustrates the weights of different criteria given by AHP Method. The consistency ratio was 0.09 , which confirms accuracy of the weightings. The obtained results indicated that the highest weights were assigned to the criteria "distance from water resources", "land use", "slope", and "soil" in a descending order while the lowest weights were given to the criteria "distance from residential areas", and "aspect", respectively. 


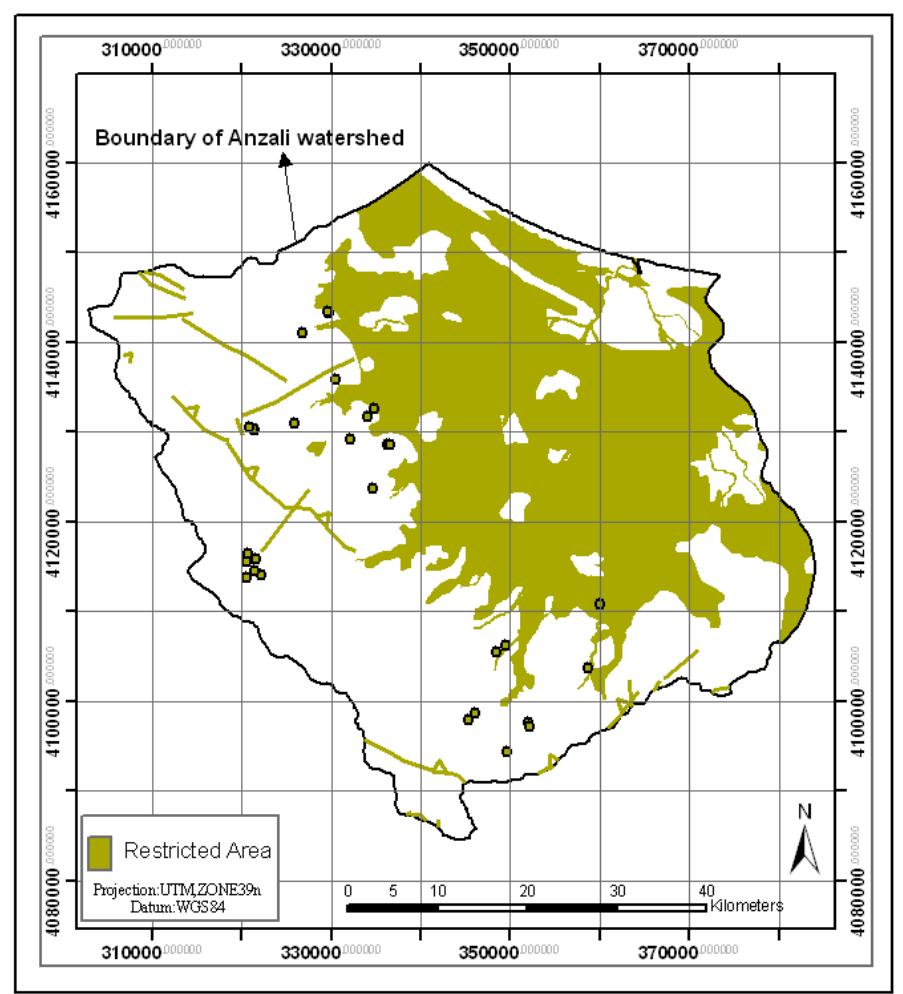

Figure 4: constrain map layers for ecotourism development in Anzali Watershed.

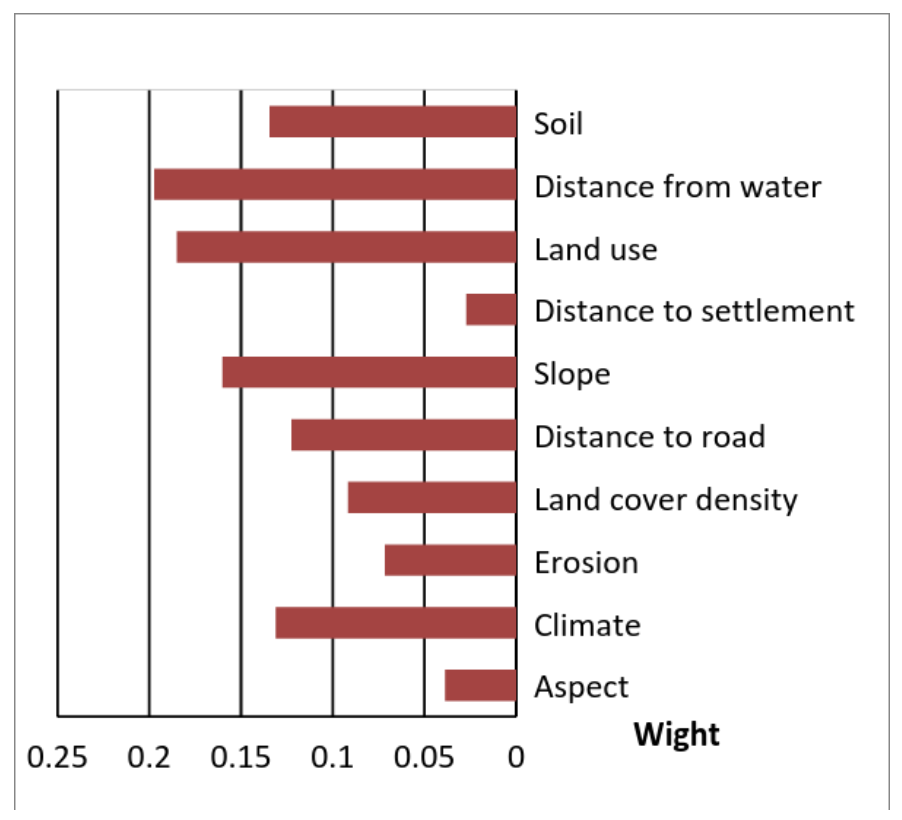

Figure 5: Weighting and prioritization of ecotourism criteria.

In arid and semi-arid areas such as Iran, water resources play a determining role in tourist destinations. Tourists prefer to spend their leisure time somewhere that possibly has the closest distance from water sources such as springs, rivers, wetlands, lakes, etc. Whatever a tourist destination is closer to water resources; it would have a greater potential for ecotourism development. Land use types would be in conflict or in line with tourist activities. As such, forest land use is of appealing land uses for ecotourism development while farmlands are not commensurate with ecotourism. Soil features can greatly affect tourist activities in tourist 
destinations so that marsh soils severely limit recreational activities or walking on loosely structured soils can cause severe erosion. Slope factor can be considered as a very basic parameter in land evaluation for ecotourism development. Tourism activities in steep areas would lead to extensive land degradation. Also, the aspect factor, due to its influence on climatic conditions e.g. number of sunny/frost days, has a role in tourists' comfort. Ecotourism that relies on natural attractions is totally incompatible with buildup areas. Accordingly, farther distances from population centers would have higher values for ecotourism development.

According to the obtained results, "slope" and "aspect" are of two important criteria for ecotourism development, of which "slope" is much more important. Although "aspect" was given less priority compared to other criteria, however, its important role in ecotourism development could not be neglected. The steep areas with a slope of more than $>45 \%$ are a limiting factor for ecotourism activities. Similar results were reported by Bunruamkaew and Murayam (2011) in Thailand and Gul et al. (2006) in Turkey. They concluded that "slope" would be an appropriate criterion for ecotourism development in areas with a slope of more than $15 \%$. "Aspect" was also another important factor for ecotourism site selection in Anzali Watershed so that eastern areas in summer time and southern slopes in winter season provide ideal conditions for ecotourism activities.

As the results suggest, climatic conditions in the watershed support ecotourism activities all year around; spring and summer are the best seasons for ecotourism activities. Similar results were reported by others researchers, e.g. Gul et al. (2006) in Turkey, and Kumari et al. (2010) in Malaysia. They also introduced number of "sunny days", and "frost days" as two other important criteria for ecotourism activities. However, in Anzali Watershed, temperature is usually above the freezing temperature.

The research findings revealed that woodland areas have unique potentials for ecotourism activities. Similarly, several studies have highlighted the importance of forests for ecotourism development. For instance, Anomasiri (2004), and Bunruamkaew and Murayam (2011) recognized forested areas as the most important zone for ecotourism development in Thailand. Similar results were reported for different climatic conditions such as Canada (Boyd and Butler, 1993), Malaysia (Amino, 2007), and Turkey (Gul et al., 2006).

In this study, "access to water resources" was given the highest weigh so that farther distance from water resources decreases suitability for ecotourism activities. The importance of "distance from water resources" was emphasized in several studies (Weaver, 2001; Gul, 2006; Kumari et al., 2010; Lindberg and Mckercher, 1997). "Distance from roads" is another important criterion for ecotourism development. It can facilitate easy access of tourists to destinations. This was highlighted by other researchers e.g. Boyd and Butler, 1993; Lindberg and Mckercher, 1997; Gul et al., 2006; Mendoza and Prabhu, and Kumari et al., 2010.

Anzali Watershed is mostly covered by coastal zones, woodlands, irrigated fields, orchards, and urban areas. In this research, irrigated farming, fragile ecosystems, land cover with a density of more than $70 \%$, wildlife corridors, urban areas, and orchards were considered as constraint zones as illustrated in Figure 6. 


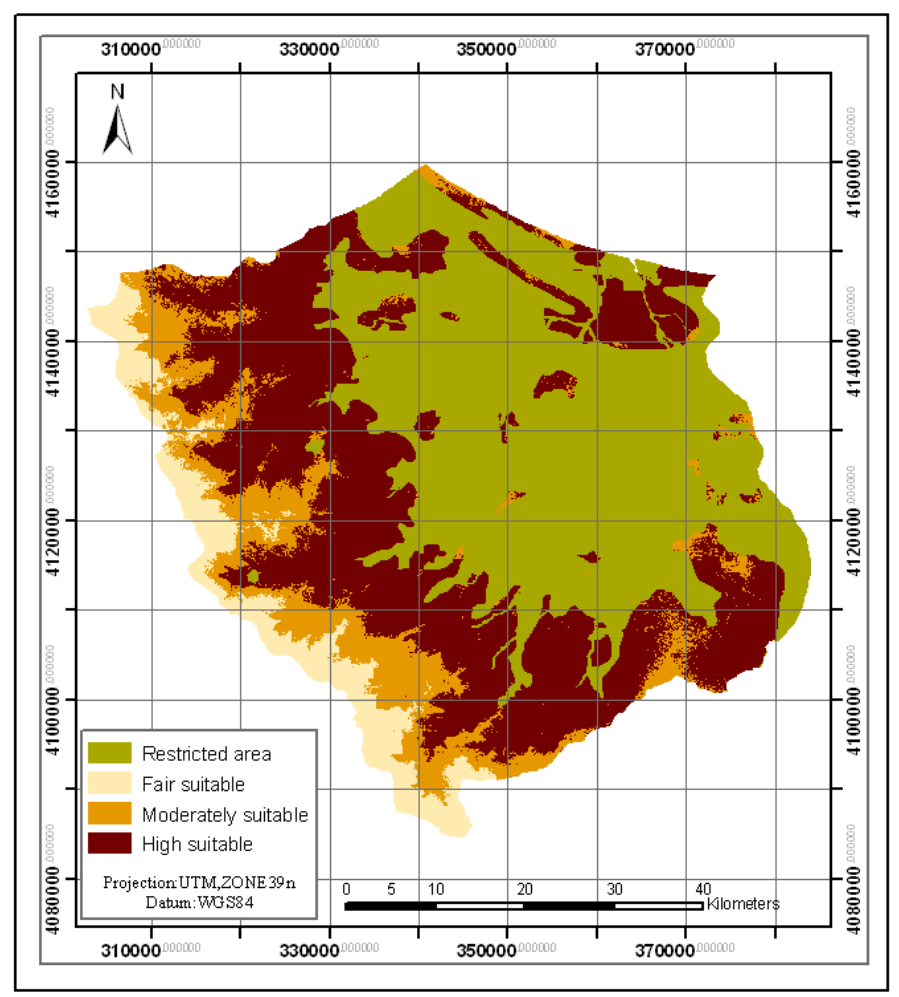

Figure 6: Land suitability for ecotourism development in Anzali Watershed.

According to the obtained results, the highest-ranking score was allocated to "distance from water resources", land use, and slope. Furthermore, special consideration was given to both "unique nature of Hyrcanian forest", and "Anzali Wetland" due to their diverse ecological conditions, which is suitable for ecotourism activities.

From altitudinal viewpoint, the watershed was divided into four categories of 0, 0-150 m,150$200 \mathrm{~m}$, and $>200 \mathrm{~m}$. Altitudes higher than $200 \mathrm{~m}$ (category 1 ) have high suitability for ecotourism activities while categories $2(150-200 \mathrm{~m})$ and $3(0-150 \mathrm{~m})$ have moderate and fair suitability for ecotourism development. Category 4 was recognized as a constraint factor for ecotourism development.

Suitability of Anzali Watershed for tourism development is presented in Figure 5.According to which, approximately $36.4 \%$ of the total study area equal to130978 ha (36.4\%) in southern watershed has high suitability for tourism development. These areas are covered mainly by forests and fragile ecosystems such as protected areas and wetlands. Accordingly, tourism activities in these areas must be done along with strict environmental considerations to avoid deterioration of the landscape. Areas with moderate suitability cover 12.8\% (46337 ha) of the study area. These areas are distributed almost all over the watershed. Moderately suitable areas include Hyrcanian forests at heights, a part of coastal zone in northern watershed, and plains. Poorly vegetated areas at high altitudes cover an area of over 26747 ha (7.4\%) in southern watershed, which have fair suitability for ecotourism activities. unsuitable areas for ecotourism development mainly include irrigated farmlands (paddy fields), landslide zone, residential areas, and land cover with a forest density of more than $70 \%$ stretched over an area of 156138 ha $(43.4 \%)$. 


\section{CONCLUSION}

This research presents a comprehensive approach integrating GIS, AHP, and MCE to identify suitable areas for sustainable ecotourism activities. The main advantages of this approach are weighting of criteria, flexibility, and capability of integrating with GIS. In this research, suitable criteria for ecotourism development were selected based upon expertise opinion, literature reviews, and field studies. It is worth mentioning that site selection criteria for ecotourism development vary in different regions depending on socio-economic and ecological conditions. In this research, land suitability for was performed using a total number of 10 criteria and 7 constraints, among which, "distance from water resources", "slope", and "land use" were topthree priority criteria. The research finding shows that the combination approach of WLC and GIS is a suitable tool for ecotourism land evaluation. This is the first time that this model is used for ecotourism devolvement of Anzali Watershed. Anzali Basin has a fragile ecosystem that requires careful planning for ecotourism development in a way to mitigate or possibly prevent deterioration of natural resources in tourist destinations. The results of the present study, by identification of suitable areas for ecotourism development, will help decision-makers to prepare an appropriate management plan restricting ecotourism activities only in places with high potentials for ecotourism development.

Fuzzy AHP is a powerful decision support system for site selection purposes. It can easily solve the issue of involving viewpoints of various stakeholders in priority setting and weighting process. By using Fuzzy AHP, site selection process will be done in the lowest possible time and cost. Providing mechanisms to control consistency of the evaluation and priority setting by Delphi panelists, it can resolve the problem of biased judgments. This is a unique capability that distinguishes it from other MCDM methods such as ELETRE, and TOPSIS. Further, Fuzzy AHP can provide the possibility of simultaneous involvement of qualitative and quantitative criteria in land evaluation studies.

\section{ACKNOWLEDGEMENT}

We would like to express our highest appreciation for the services rendered by Ravian Danesh Mohit Company in providing insightful comments and proofreading of the manuscript.

\section{REFERENCES}

Abidin, Z. Z.The identification of criteria and indicators for the sustainable management of ecotourism in Taman Negara National Park, Malaysia: A Delphi Consensus. Ph.D. Dissertation, West Virginia University, Morgantown, WV, USA, 1995.

Amino, M. A. Geographic information system (GIS) and multi-criteria analysis for sustainable tourism planning. Masters thesis, University Technology of Malaysia, 2007.

Anomasiri, W. Eastern philosophy of ecotourism management model in Mae Son Province, Thailand. Master Thesis, Technology of Environmental Management, Faculty of Graduate Studies, Mahidol University, Bangkok, Thailand, 2004.

Babaie-Kafaky, S.; Mataji A.; Ahmadisani N. Ecological capability assessment for multiple-use in forest areas using GIS- based multiple criteria decision making approach. American Journal of Environmental Sciences, v.5, n.6, p. 714-721, 2009.

Bol. Ciênc. Geod., sec. Artigos, Curitiba, v. 21, no 2, p.340-353, abr-jun, 2015. 
Boyd, S. W.; Butler, R. W.; Haider W. Identifying criteria and establishing parameter for forestbased ecotourism in Northern Ontario, Canada. Ressources naturelles Canada, Service canadien des forêts, 7 pages , 1995.

Boyd, S. W.; Butler, R. W. Review of the development of ecotourism with respect to identifying criteria for ecotourism for Northern Ontario. Department of Natural Resources/ Forestry, Ministry of Natural Resources. Sault Ste. Marie, Ontario, 1993.

Bunruamkaew, K.; Murayama, Y. Site suitability evaluation for ecotourism using GIS \& AHP: a case Study of SuratThani Province, Thailand.

Procedia - Social and Behavioral Sciences, v.21, p. 269-278, 2011.

Ceballos-Lascurain, H. Tourism, Ecotourism, and Protected Areas. IUCN Protected Areas Program, Gland, Switzerland and Cambridge, UK, 1996.

Culbertson, K.; Hershberger, B.; Jackson, S.; Mullen, S.; Olson, H. GIS a tool for regional planning in mountain regions: Case studies from Cana Brazil, Japan, and the USA. In: Price, M.F. \& Heywood, and D.I. (Eds.), Mountain environments and GIS. Taylor \& Francis, London, p. 99-118, 1994.

Dhammapitaka, P.; Payuto, P. A. Sustainable development (In Thai). $7^{\text {th }}$ printing. KomolKhimthong Foundation Publishing, Bangkok, 2000.

Eastman, J. R. IDRISI and Guide to GIS and Image Processing. Clark University, 2006.

FAO, Approaches to land classification, Soils Bulletin 22. FAO, Rome, 1974.

Gul, A. M.; Orucu, K.; Oznur, K. An approach for recreation suitability analysis to recreation planning in Golchuk Nature Park. Journal of Environmental Management, v.37, n.5, p.606625, 2006.

Japan International Cooperation Agency (JICA). Report of Anzali wetland watershed master plan. Department of Environment, Iran, 2005.

Japan International Cooperation Agency (JICA). Report of Anzali wetland watershed master plan. Department of Environment, Iran, 2012.

Kheirkhah Zarkesh, M. M.; Ghoddusi, J.; Zaredar, N.; Soltani, M. J.; Jafari, S.; Ghadirpour, A. Application of Spatial Analytical Hierarchy Process model in land use planning. Journal of Food, Agriculture and Environment, v.8, n.2, p. 970-975, 2010.

Kiker, G. A.; Bridges, T. S.; Varghese, A.;Seager, T. P.; Linkov, I. Application of multi criteria decision analysis in environmental decision making. Integrated Environmental Assessment and Management, v.1, n.2, P.95-108, 2005.

Kumari, S.; Behera, M. D.; Tewari, H. R. Identification of potential ecotourism sites in West District, Sikkim using geospatial tools. Tropical Ecology, v.51, n.1, p.75-85, 2010.

Leksakundilok, A. Ecotourism and community-based ecotourism in the Mekong Region. Working paper series: working paper no.10, The Australian Mekong Resource Centre, University of Sydney, Sydney, 2004.

Lindberg, K.; Mckercher, B. Ecotourism: a critical overview. Pacific Tourism Review, v.1, n.1, p. 65-79, 1997.

Malczewski, J. GIS-based land use suitability analysis: A critical overview. Progress in Planning, v.62, n.1, p. 3-65, 2004. 
Mendoza, G.; Prabhu R. Participatory modeling and analysis for sustainable forest management: Overview of soft system dynamics models and applications. Forest Policy and Economics, v.9, n.2, p. 179-196, 2006.

Ok, K. Multiple criteria activity selection for ecotourism planning in igneada. Turkish. Journal of Agriculture and Forestry, v.30, p. 153-164, 2006.

Saaty, T. L. The Analytic Hierarchy Process, New York: McGraw-Hill, 1980.

Saaty, T. L.; Vargas L. G. Models, methods, concepts and applications of the analytic hierarchy process. International series in operations research and management sciences. Kluwer Academic Publisher, springer, p.333, 2001.

Sharpley, R. Ecotourism: a consumption perspective. Journal of Ecotourism, v.5, n.1-2, p. 7-22. 2006.

Vaidya, O. S.; Kumar S. Analytic hierarchy process: An overview of applications. European Journal of Operational Research, v.169, n.1, p. 1-29, 2006

Weaver, D. Ecotourism, Brisbane: John Wiley and Sons, 2001.

Zaredar N.; Kheirkhah Zarkesh, M. M.; Ghadirpour, A.;Jozi, S. A.; Jafari, S.International Conference on Chemistry and Chemical Engineering (ICCCE), Kyoto, Japan, 1-3 Aug. 2010.

(Recebido em maio de 2014. Aceito em outubro de 2014). 


\title{
ANÁLISES ESPECTRAIS DA VEGETAÇÃO COM DADOS HYPERION E SUA RELAÇÃO COM A CONCENTRAÇÃO E O FLUXO DE $\mathrm{CO}_{2}$ EM DIFERENTES AMBIENTES NA AMAZÔNIA BRASILEIRA
}

\author{
Spectral analysis of vegetation with Hyperion data and his relationship with the \\ concentration and the flux of $\mathrm{CO} 2$ in different environments in the Brazilian
}

Amazon

\section{SUZY CRISTINA PEDROZA DA SILVA \\ GUSTAVO MACEDO DE MELLO BAPTISTA}

\author{
Programa de Pós-Graduação em Geociências Aplicadas \\ Instituto de Geociências \\ Universidade de Brasília - UnB/IG \\ Email: suzyycris@unb.br; gmbaptista@unb.br
}

\section{Resumo:}

A modelagem espectral é uma das ferramentas importantes para a determinação de estimativa de parâmetros biofísicos de um local. Correlacionar a concentração e o fluxo de dióxido de carbono, por meio de medições indiretas é um grande avanço na área das geociências. A metodologia desenvolvida para o sequestro florestal de carbono CO2flux, CO2fluxEVI e CO2fluxEVI2, a partir do sensor Hyperion envolveu ambientes naturais e antrópicos, tornando-o eficaz quando associada à variabilidade de ecótipos existentes na Amazônia Brasileira. Resultados desse estudo apontaram que os índices NDVI, EVI e EVI2 podem compor a estrutura do índice de sequestro florestal de carbono, CO2flux. Entretanto, fez-se necessário avaliar a potencialidade e comparação dos índices em relação à detecção do sequestro florestal de carbono, associado as medições diretas de $\mathrm{CO}_{2}$ nas torres micrometeorológicas. Após o processamento das imagens hiperespectrais e análises estatísticas dos índices sugeridos pôde-se inferir que o CO2flux com a utilização do NDVI tem melhor ajustamento, quando associado aos dados de concentração de $\mathrm{CO}_{2}$ (ppm) medidos no topo das torres, e com os dados de fluxo $\left(\mathrm{mol} \cdot \mathrm{m}^{-2} \cdot \mathrm{s}^{-1}\right)$, uma vez que as correlações possuem similaridades e são estatisticamente significativos com os dados do sensor Hyperion.

Palavras-chave: imagem hiperespectral, sequestro florestal de carbono, torres micrometeorológicas.

\footnotetext{
Abstract:

The spectral modeling is one of the important tools for determining biophysical parameters estimation of a location. Correlate the concentration and carbon dioxide flux through indirect Bol. Ciênc. Geod., sec. Artigos, Curitiba, v. 21, no 2, p.354-370, abr-jun, 2015.
} 
da Silva, S.C.P; Baptista, G.M.D..

measurements is a large advance in the field of geosciences. The methodology developed for forest carbon sink CO2flux, CO2fluxEVI and CO2fluxEVI2 from Hyperion involving natural and anthropic environments, making it effective when associated with variety of ecotypes existing in the Brazilian Amazon. Results of this study showed that NDVI indices, EVI and EVI2 could compose the rate structure of the forest sink of carbon, $\mathrm{CO} 2$ flux. However, it was necessary to evaluate the potential and comparison of ratios in relation to detection of forest carbon sink associated to the direct measurements of $\mathrm{CO}_{2}$ in micrometeorological towers. After processing the hyperspectral imaging and statistical analysis of the suggested ratios, it could be inferred that CO2flux has a better adjustment when using NDVI, when associated to $\mathrm{CO}_{2}(\mathrm{ppm})$ concentration data measured from the top of the towers, as well as the data flux $\left(\mathrm{mol} \cdot \mathrm{m}^{-2} \cdot \mathrm{s}^{-1}\right)$, since the correlations have similarities and are statistically significant at the Hyperion data.

Keywords: hyperspectral image, forest sink of carbon, micrometeorological towers.

\section{Introdução}

Os índices espectrais, em sensoriamento remoto, são informações bastante utilizadas para o monitoramento de diferentes ambientes na superfície terrestre. Para a vegetação, diversos índices têm sido propostos. Estes utilizam especialmente as regiões do visível e infravermelho próximo (Ponzoni; Shimabukuro, 2010), baseando-se no fato de que a energia refletida nessas regiões do espectro é diretamente relacionada à atividade fotossintética da vegetação.

De modo geral, o índice de vegetação NDVI (Normalized Difference Vegetation Index), desenvolvido por Rouse et al. (1973), é o mais sensível à presença de clorofila no processo de fotossíntese (Huete et al., 1997), entretanto, tem sua eficiência diminuída quando o alvo possui elevada biomassa de vegetação devido ao fenômeno de saturação (Carlson; Ripley, 1997; Huete, 1988; Huete et al., 2002). Assim, nesse estudo foram utilizados também os índices, de vegetação melhorado ou realçado EVI - Enhanced Vegetation Index (Huete et al., 1997) e o EVI2 Enhanced Vegetation Index 2 (Jiang et al., 2008).

O EVI emprega as bandas espectrais do infravermelho próximo, região do vermelho e a reflectância na faixa do azul é utilizada para indicar o vigor vegetativo (Huete et al., 1997). Porém, a banda do azul, utilizada no EVI, apresenta relação sinal/ruído muito baixa, não se encontra em muitos sistemas sensores e nesse caso, Jiang et al. (2008) desenvolveram um novo índice de vegetação, baseado no EVI, mas sem a banda do azul, denominado de EVI2. De acordo com Jensen (2009), o EVI é um NDVI que possui na sua estrutura um fator de ajuste para o solo e coeficientes que descrevem o uso da banda azul para a correção da banda vermelha, quanto ao espalhamento atmosférico por aerossóis. Todavia, muitos sensores não operam na região espectral do azul. Isso implica que o EVI possui uma limitação de aplicabilidade para alguns sensores que não operam na região do azul e pode ser difícil comparar estatisticamente resultados desse índice com outros índices de vegetação, a partir do sensor Hyperion.

Para Jiang et al. (2008) a alternativa estratégica para o desenvolvimento do EVI2 era decompor a equação EVI original para eliminar a banda azul, assumindo que reflectância na banda azul, pode ser expressa como uma função na banda vermelha. No seu estudo, o EVI2 foi desenvolvido com base em dados do sensor MODIS e para outros sensores com diferentes funções de resposta espectral vermelho ou azul, pode ser diferente, por isso a relação entre EVI e EVI2 pode variar ligeiramente de um sensor para outro.

Desde a década de 80, estudos que envolvem sensoriamento remoto por meio dos índices de vegetação e $\mathrm{CO}_{2}$ eram desenvolvidos em diferentes ecossistemas terrestres. Box, Holben e Kalb 
(1989) utilizando o sensor AVHRR (Advanced Very High Resolution Radiometer) sobrepuseram mensurações diretas de dados de fluxo de $\mathrm{CO}_{2}$ e o NDVI, os autores ressaltaram que a relação entre as variáveis era baixa, devido aos efeitos da sazonalidade e da sensibilidade do saldo líquido de $\mathrm{CO}_{2}$ encontrados em determinadas partes no mundo.

Rahman et al. (2000) propuseram um novo índice, denominado de CO2flux, para medir a eficiência do processo de sequestro de carbono pela vegetação. No seu estudo, utilizando imagens do sensor AVIRIS (Airborne Visible InfraRed Imaging Spectrometer) numa floresta boreal com povoamento florestal e solos relativamente homogêneos, na região central do Canadá (Estados Unidos), os autores alcançaram resultados satisfatórios com uma alta correlação entre o CO2flux com dados de fluxo de $\mathrm{CO}_{2}$ de seis torres micrometeorológicas. Posteriormente, Baptista (2003) apresentou resultados satisfatórios com a aplicação do CO2flux para mensurar a eficiência do processo de sequestro de carbono pela vegetação na fase clara da fotossíntese.

Recentemente, com o advento dos sensores hiperespectrais, análises minuciosas sobre as propriedades dos alvos ou materiais vem sendo estudados com maior eficiência, representando atualmente uma nova abordagem com relação às técnicas de sensoriamento remoto (Carvalho Júnior et al., 2002).

Os sensores hiperespectrais, por possuir em alta dimensionalidade espectral, fornecem uma diversidade de informações sobre a estrutura e propriedades bioquímicas e fisiológicas, concentrações de nutrientes, pigmento, FPAR e utilização da eficiência da luz (Asner et al., 2005).

No Brasil, a aplicabilidade das imagens hiperespectrais do sensor Hyperion vem avançando gradativamente. Muitos autores utilizam as imagens do sensor, a fim de verificar o potencial para analisar diversas feições, inclusive as de vegetação e $\mathrm{CO}_{2}$ (Galvão et al., 2005; Schramm; Vibrans, 2007) e Souza, 2009).

Dessa forma, esse estudo analisou a concentração e o fluxo de dióxido de carbono, a partir das torres de medições micrometeorológicas instaladas na Amazônia Brasileira, correlacionando-as com as análises espectrais da vegetação a partir de imagens Hyperion.

\section{Material e métodos}

\section{1 Área de estudo}

O estudo foi realizado na região amazônica, envolvendo áreas naturais e de influências antrópicas, onde estão localizadas as torres micrometeorológicas do LBA (Large Scale Biosphere-Atmosphere Experiment in Amazonia). As cinco torres do estudo são denominadas de K34, K83, K67, FNS e SIN (Figura 1).

A torre K34, localiza-se em ambiente de floresta primária a cerca de $60 \mathrm{~km}$ ao norte de Manaus, pela rodovia BR 174. As torres K83 (exploração seletiva de madeira) e K67 (floresta primária) localizadas em Santarém (PA) foram instaladas na Floresta Nacional do Tapajós a aproximadamente 5 e $6 \mathrm{~km}$, respectivamente de distância, em linha reta da rodovia BR-163. A Torre FNS (pastagem) está localizada na Fazenda Nossa Senhora no município de Ouro Preto d'Oeste nas proximidades da rodovia BR-163, a cerca de $50 \mathrm{~km}$ de Ji-Paraná, na região sudoeste de Rondônia. A torre SIN localiza-se a aproximadamente $50 \mathrm{~km}$ nordeste de Sinop (MT), sua cobertura vegetal é caracterizada por uma Floresta de Transição Amazônia Cerrado. 
da Silva, S.C.P; Baptista, G.M.D..

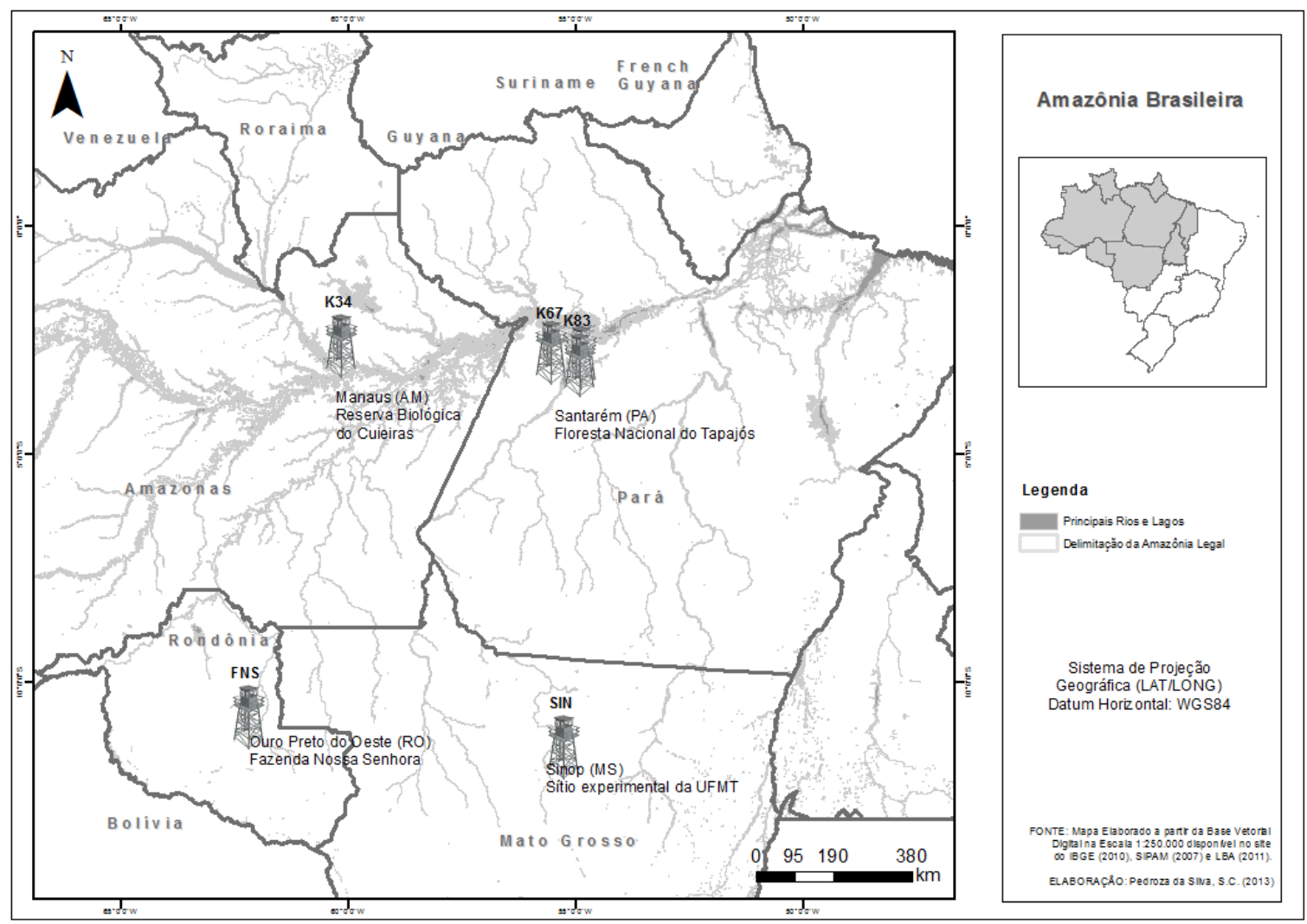

Figura 1: Localização das cinco torres micrometeorológicas na Amazônia Brasileira.

Os sítios experimentais do Amazonas e Pará estão inseridos em Unidades de Conservação e as torres de Rondônia e Mato Grosso estão sob a responsabilidade da Universidade de Rondônia, no Campus de Ji-Paraná e da Universidade Federal do Mato Grosso, respectivamente (Tabela 1).

Tabela 1: Torres de Fluxo de $\mathrm{CO}_{2}$ na Amazônia Brasileira.

\begin{tabular}{|c|c|c|c|c|c|c|c|}
\hline \multirow{2}{*}{$\begin{array}{l}\text { N. }{ }^{0} \\
\text { de } \\
\text { Torre }\end{array}$} & \multirow{2}{*}{ Estado } & \multirow{2}{*}{ Município } & \multirow{2}{*}{ Localidade } & \multirow{2}{*}{ Sítios } & \multirow{2}{*}{$\begin{array}{l}\text { Nome } \\
\text { da } \\
\text { Torre }\end{array}$} & \multicolumn{2}{|c|}{$\begin{array}{c}\text { Coordenadas } \\
\text { Geográficas (decimal) }\end{array}$} \\
\hline & & & & & & $\begin{array}{l}\text { Latitude } \\
\text { (S) }\end{array}$ & $\begin{array}{l}\text { Longitude } \\
(\mathrm{W})\end{array}$ \\
\hline 1 & Amazonas & Manaus & $\begin{array}{c}\text { Reserva } \\
\text { Biológica do } \\
\text { Cuieiras } \\
\end{array}$ & $\begin{array}{l}\text { Floresta } \\
\text { Primária }\end{array}$ & K34 & 2,60900 & 60,20910 \\
\hline 2 & \multirow{2}{*}{ Pará } & \multirow{2}{*}{ Santarém } & $\begin{array}{c}\text { Floresta } \\
\text { Nacional do } \\
\text { Tapajós } \\
\end{array}$ & $\begin{array}{c}\text { Exploração } \\
\text { Seletiva de } \\
\text { Madeira } \\
\end{array}$ & K83 & 3,01806 & 54,96889 \\
\hline 3 & & & $\begin{array}{l}\text { Floresta } \\
\text { Nacional do } \\
\text { Tapajós }\end{array}$ & $\begin{array}{l}\text { Floresta } \\
\text { Primária }\end{array}$ & K67 & 2,85611 & 54,95806 \\
\hline 4 & Rondônia & $\begin{array}{l}\text { Ouro } \\
\text { Preto do } \\
\text { Oeste }\end{array}$ & $\begin{array}{l}\text { Fazenda Nossa } \\
\text { Senhora }\end{array}$ & Pastagem & FNS & 10,7500 & 62,26000 \\
\hline 5 & $\begin{array}{l}\text { Mato } \\
\text { Grosso }\end{array}$ & Sinop & $\begin{array}{c}\text { Sítio } \\
\text { experimental da } \\
\text { UFMT }\end{array}$ & $\begin{array}{l}\text { Floresta de } \\
\text { Transição } \\
\text { (Floresta }\end{array}$ & SIN & 11,41230 & 55,32470 \\
\hline
\end{tabular}




\begin{tabular}{c|l|l|l|l|l|l|}
\hline $\begin{array}{c}\text { N. } \\
\text { de } \\
\text { Torre }\end{array}$ & Estado & Município & Localidade & Sítios & $\begin{array}{c}\text { Nome } \\
\text { da } \\
\text { Torre }\end{array}$ & $\begin{array}{c}\text { Coordenadas } \\
\text { Geográficas (decimal) }\end{array}$ \\
\hline & & & & $\begin{array}{c}\text { Latitude } \\
\text { (S) }\end{array}$ & $\begin{array}{c}\text { Longitude } \\
\text { (W) }\end{array}$ \\
\hline
\end{tabular}

\subsection{Pré-processamento das imagens Hyperion}

Neste estudo foram utilizadas 21 imagens hiperespectrais, sendo para a torre K34 (5 cenas), K8 ( 8 cenas), K67 ( 5 cenas), FNS ( 2 cenas) e SIN (1 cena) obtidas pelo sensor Hyperion, instalado no satélite EO-1 (Earth Observing-1) da NASA. Cada imagem possui 242 bandas, nos comprimentos de onda de 0,4 a 2,5 $\mu$ m e sua resolução espacial é de 30 metros, com largura de $7,5 \mathrm{~km}$.

Como o sensor Hyperion opera a partir de uma plataforma orbital com consequente relação sinal ruído moderado e, devido aos efeitos atmosféricos, o processamento dos dados demanda um cuidado maior (DATT et al., 2003), foram realizados primeiramente, a conversão de ND (Número Digital) para radiância, a correção atmosférica e a minimização dos ruídos na imagem.

A determinação do CO2flux nas imagens do Hyperion foi realizada mediante o reescalonamento dos valores ND das imagens de radiância. Para extração da informação referente ao CO2flux, utilizou-se as bandas calibradas no VNIR (8-57), que foram multiplicadas por 40 (EO-1 USER GUIDE, 2003). Os dados foram convertidos mediante a ferramenta band math do ENVI.

A correção dos efeitos atmosféricos foi realizada utilizando o modelo de transferência radiativa MODTRAN, com o aplicativo FLAASH (Fast Line-of-sight Atmospheric Analysis of Spectral Hypercubes). Os dados de latitude e longitude, hora de obtenção da imagem, altitude do sensor de $705 \mathrm{~km}$, visibilidade inicial de $40 \mathrm{~km}$ e informações dos sítios experimentais das torres micrometeorológicas na região amazônica foram utilizados para alimentação do FLAASH. Os parâmetros do modelo incluíram uma atmosfera tropical com um modelo de aerossol rural, com concentração média de $\mathrm{CO}_{2}$ na atmosfera de $390 \mathrm{ppm}$, e as altitudes do terreno foram verificadas a partir de cada sítio experimental. Assim para a torre K34 (130m), K83 (150m), K67 (90m), FNS (150m) e SIN (280m).

Embora as imagens hiperespectrais forneçam um espectro contínuo, gera-se uma grande quantidade de dados necessários para o processamento, influenciando na demanda computacional. Além de possuir bandas estreitas contíguas, grande parte dos dados do espectro é redundante, assim como sua suscetibilidade às interferências de ruídos, o que dificulta a identificação e a análise de materiais. Neste estudo foi aplicado o método MNF (Minimum Noise Fraction). O método MNF foi desenvolvido para eliminar a alta correlação com o mínimo de perda de informação, num princípio estatístico de redução de dados, tornando evidentes feições que não eram percebidas visualmente. Carvalho Júnior et al. (2002) afirmam que as imagens geradas com o processo de inversão do método de MNF apresentam espectros límpidos de ruído, pois as primeiras bandas compõem cerca de $90 \%$ das informações, e o restante são ruídos.

Para o georreferenciamento foram utilizados os coeficientes da função de mapeamento polinomial de primeira ordem e estimados por meio de um conjunto de pontos que foram registrados tendo como referência a imagem de nível 1Gst Geotiff da United States Geological Survey (USGS) referentes as localizações de cada área, conduzidos no programa ENVI 4.8. 


\subsection{Determinação do fluxo de $\mathrm{CO}_{2}$ por índices espectrais}

O índice CO2flux (RAHMAN et al., 2000) mede a eficiência do processo de sequestro de carbono pela vegetação. Para sua determinação é utilizada a integração do NDVI (Normalized Difference Vegetation Index) com o sPRI (Photochemical Reflectance Index reescalonado para valores positivos). O NDVI utiliza as bandas do vermelho e do infravermelho num processo de diferença normalizada pela soma, que visa representar percentualmente a relação de uma banda com outra. Essa operação aritmética permite uma clara distinção das áreas com vegetação, devido a relação da absorção na faixa do vermelho e o pico de reflectância na faixa do infravermelho próximo, o que permite a medição da intensidade da banda de absorção ou feição espectral. $\mathrm{O}$ índice NDVI (Equação 1) consiste na razão da diferença de reflectância entre a feição de absorção do vermelho $(0,66 \mu \mathrm{m})$ e o aumento de albedo que ocorre nos espectros de vegetação após o início do infravermelho próximo $(0,8 \mu \mathrm{m})$.

$$
N D V I=\frac{R_{0,800}-R_{0,660}}{R_{0,800}+R_{0,660}}
$$

Em que: R é o valor de reflectância em cada comprimento de onda, ajustado para os dados Hyperion.

O PRI (Equação 2) é a razão da diferença existente entre a feição de absorção no azul $(0,531 \mu \mathrm{m})$ e o pico de reflectância do verde $(0,57 \mu \mathrm{m})$ e pode ser correlacionado com a eficiência da luz na fotossíntese (GAMON, SERRANO e SURFUS, 1997).

$$
P R I=\frac{R_{0,531}-R_{0,57}}{R_{0,531}+R_{0,57}}
$$

Em que: R é o valor de reflectância em cada comprimento de onda, ajustado para os dados Hyperion.

Entretanto, o PRI precisa de um reescalonamento de seus valores evitando dados negativos sendo denominado de sPRI (Equação 3). O reescalonamento para valores positivos é necessário para normalizar os dados de "verdor" da vegetação. O sPRI é obtido por meio do PRI, adicionando uma unidade e dividindo o resultado por dois.

$$
s P R I=(P R I+1) / 2
$$

A determinação do índice CO2flux é realizada pela multiplicação, no módulo Band Math, dos planos de informação NDVI e sPRI.

Como proposto para minimização dos efeitos de saturação gerados pela presença do NDVI, foram analisados também, os índices (EVI e EVI2), para compor a estrutura do CO2flux, gerando os índices CO2fluxEVI e CO2fluxEVI2.

O índice de vegetação melhorado ou realçado, EVI, (Equação 4) emprega as bandas espectrais do infravermelho próximo, região do vermelho e a reflectância na faixa do azul é utilizada para indicar o vigor vegetativo (Huete, 1997).

$$
E V I=G \frac{N-R}{N+C_{1} R-C_{2} B+L}
$$

Em que: $\mathrm{N}, \mathrm{R}$ e $\mathrm{B}=$ reflectância do infravermelho próximo, vermelho e azul; $\mathrm{C} 1$ = coeficiente de ajuste para efeito de aerossóis da atmosfera no vermelho $=6 ; \mathrm{C} 2=$ coeficiente de ajuste para efeito de aerossóis da atmosfera no azul =7,5; $\mathrm{L}=$ fator de ajuste para o solo $=1$; e $\mathrm{G}=$ fator de ganho $=2,5$

O EVI2 (Equação 5) é funcionalmente equivalente ao EVI, embora, seja ligeiramente mais propenso a ruído de aerossol mas, com os avanços contínuos das técnicas de correções 
atmosféricas, essa evidência tornar-se menos significativa ao longo do tempo (JIANG et al., 2008).

$$
E V I 2=2,5 \frac{(N-R)}{N+2,4 R+1}
$$

Em que: $\mathrm{N}$ e $\mathrm{R}$ = reflectância do infravermelho próximo e vermelho.

\subsection{Aquisição dos Dados Micrometeorológicos}

Os dados de campo são referidos ao período de 2000 a 2005 e solicitados junto aos escritórios locais do Programa LBA. As visitas às torres foram realizadas entre os meses de agosto a outubro de 2013, com o auxílio dos pesquisadores, professores, estudantes e técnicos de Instituições que são vinculados às pesquisas realizadas em cada torre.

Os sítios experimentais das torres utilizam o sistema Eddy Covariance para medir as trocas de $\mathrm{CO}_{2}$ e a atmosfera. É um sistema que mede as três componentes da velocidade do vento (velocidade horizontal do vento a leste, velocidade horizontal do vento a norte e a velocidade vertical do vento) e a temperatura do ar, e o intervalo de tempo utilizado no cálculo das médias e flutuações dos sinais turbulentos são de 30 minutos (Aguiar et al., 2006).

A concentração média de $\mathrm{CO}_{2}$ nas torres micrometeorológicas pesquisadas são medidos com grande acurácia por um analisador de gás infravermelho, comumente conhecido como IRGA (InfraRed Gas Analyzers). O analisador de gás de caminho aberto modelo (LI-7500, LI-COR, Inc.), é um instrumento utilizado para realizar medidas simultâneas das concentrações de $\mathrm{CO}_{2} \mathrm{e}$ vapor d'água na atmosfera. Os dados também podem ser acessados na Rede FLUXNET (fluxnet.ornl.gov). Os dados de $\mathrm{CO}_{2}$ são mantidos na frequência de 30 minutos para permitir o processamento de dados padronizados.

$\mathrm{O}$ perfil de concentração de $\mathrm{CO}_{2}$ foi verificado pelos instrumentos instalados em diferentes alturas, ao longo das torres e para obter a informação necessária para a análise, as médias dos dados foram extraídas e associados às medidas espectrais na data e horário da passagem do sensor Hyperion.

\section{Resultados e discussão}

\subsection{Modelagem hiperespectral do sequestro florestal de carbono}

Como as torres micrometeorológicas estão localizadas em diferentes ambientes na Amazônia (floresta primária, exploração seletiva de madeira e pastagem) fez-se necessária a verificação de qual índice (NDVI, EVI e EVI2) aplicar, para verificação do sequestro florestal de carbono.

Na tabela 2, observa-se que nas florestas primárias (K34, K67 e SIN) e na área de exploração seletiva de madeira (K83), os valores de NDVI são elevados, mantendo uma média em torno de 0,820, com pequenas variações, devido as épocas do ano que foram medidos (chuvosa e seca). $\mathrm{Na}$ área de pastagem (FNS), a variação do NDVI foi mais intensa, alcançando uma diferença de amplitude de aproximadamente 0,514 , com valores médios de 0,306 . Isso pode ser explicado, devido às condições ambientais encontradas nos pontos amostrados. As áreas de pastagens são áreas mais secas, com maior carência de água, diferentemente das florestas primárias, devido 
da Silva, S.C.P; Baptista, G.M.D..

uma quantidade maior de biomassa. Esses valores de NDVI são relacionados ao valor de um pixel da imagem Hyperion.

Os resultados da tabela 2 corroboram com os resultados de Nascimento (2012), os valores encontrados mostram que nas florestas primárias o NDVI oscilam em torno de 0,888. Trata-se de regiões com uma quantidade maior de conteúdos de água do solo e da biomassa verde, enquanto que na área de pastagem a variação do NDVI é mais drástica, alcançando uma diferença de aproximadamente 0,3, com valores máximos e mínimos de 0,736 e 0,443. A explicação foi a intensificação da seca que afetou o crescimento da pastagem, ou também por estar relacionado às atividades de queimadas na área, que reduzem drasticamente os valores de NDVI.

Os dados representados na tabela 2 mostram que o índice NDVI possui os maiores valores no pixel em relação aos outros dois índices EVI e EVI2. Apesar de apresentar alguns valores baixos, uma vez que os dados das cinco torres divergem na localização, nos tipos de ambientes e datas, não houve valores negativos em nenhum dos índices.

Tabela 2: Valores de NDVI para os pontos das torres.

\begin{tabular}{|c|c|c|c|}
\hline Torre & Cenas do Sensor & Época do Ano & NDVI \\
\hline \multirow{5}{*}{$\begin{array}{c}\text { K34 } \\
\text { (Floresta Primária) }\end{array}$} & 2002219 & Seca & 0.860 \\
\hline & 2002226 & Seca & 0.890 \\
\hline & 2002315 & Seca & 0.844 \\
\hline & 2003174 & Chuvosa & 0.859 \\
\hline & 2005218 & Seca & 0.910 \\
\hline \multirow{8}{*}{$\begin{array}{c}\mathbf{K 8 3} \\
\text { (Exploração Seletiva de Madeira) }\end{array}$} & 2001211 & Chuvosa & 0.859 \\
\hline & 2001227 & Seca & 0.778 \\
\hline & 2001307 & Seca & 0.831 \\
\hline & 2002189 & Chuvosa & 0.853 \\
\hline & 2002221 & Seca & 0.886 \\
\hline & 2003137 & Chuvosa & 0.724 \\
\hline & 2003185 & Chuvosa & 0.859 \\
\hline & 2003233 & Seca & 0.879 \\
\hline \multirow{5}{*}{$\begin{array}{c}\text { K67 } \\
\text { (Floresta Primária) }\end{array}$} & 2002189 & Chuvosa & 0.850 \\
\hline & 2002269 & Seca & 0.892 \\
\hline & 2002285 & Seca & 0.733 \\
\hline & 2003233 & Seca & 0.864 \\
\hline & 2005206 & Chuvosa & 0.869 \\
\hline \multirow{2}{*}{$\begin{array}{c}\text { FNS } \\
\text { (Pastagem) }\end{array}$} & 2003220 & Seca & 0.319 \\
\hline & 2003236 & Seca & 0.294 \\
\hline SIN (Floresta de Transição Amazônia-Cerrado) & 2002191 & Seca & 0.850 \\
\hline
\end{tabular}

A média do NDVI nas cinco torres apresenta valores em torno de 0,795 (com desvio padrão de 0,169). Apesar do EVI e EVI2 apresentarem as mesmas tendências, os valores de EVI2 com média de 0,444 (com desvio padrão de 0,114), e EVI com média de 0,416 (com desvio padrão de 0,111 ). Esses últimos dois índices apresentam valores menores do que aqueles verificados no índice NDVI, para os mesmos dias observados. O coeficiente de variação de NDVI foi o mais baixo, 21,3\%, enquanto que o EVI2 apresentou 25,7\% e o EVI, 26,6\% (Tabela 3). 
Tabela 3: Estatística descritiva para os índices NDVI, EVI e EVI2.

\begin{tabular}{r|ccc}
\hline \multirow{2}{*}{ ATRIBUTOS } & \multicolumn{3}{c}{ Índices de Vegetação } \\
\cline { 2 - 4 } & NDVI & EVI & EVI2 \\
\hline Tamanho da amostra & 21 & 21 & 21 \\
Mínimo & 0.294 & 0.173 & 0.194 \\
Máximo & 0.910 & 0.548 & 0.576 \\
Média & 0.795 & 0.416 & 0.444 \\
Variância & 0.029 & 0.012 & 0.013 \\
Desvio Padrão & 0.169 & 0.111 & 0.114 \\
Erro Padrão & 0.037 & 0.024 & 0.025 \\
Coeficiente de Variação & $21.3 \%$ & $26.6 \%$ & $25.7 \%$ \\
\hline
\end{tabular}

Na figura 2, é possível verificar a saturação do NDVI em relação aos índices EVI e EVI2, que possuem valores no pixel mais baixos. Os valores de NDVI para as áreas de florestas primárias e com intervenção (K34, K67, K83 e SIN) são elevados, com média em torno de 0,847 , com elevada concentração de biomassa, indicando o fenômeno de saturação. O comportamento se mantém em relação ao valores de EVI e EVI2 para as mesmas áreas de floresta.

Os índices melhoram a capacidade de detecção em regiões com maiores densidades de biomassa, uma vez que reduz a influência do sinal do solo e da atmosfera sobre a resposta do dossel da floresta, que pode ser observado nas médias do índice EVI, em torno de 0,440, e EVI2 em torno de 0,468. Na área da torre FNS, com áreas abertas e vegetação mais seca, tanto o NDVI quantos os índices EVI e EVI2 apresentaram valores baixos, com médias de 0,306; 0,194 e 0,215, respectivamente.

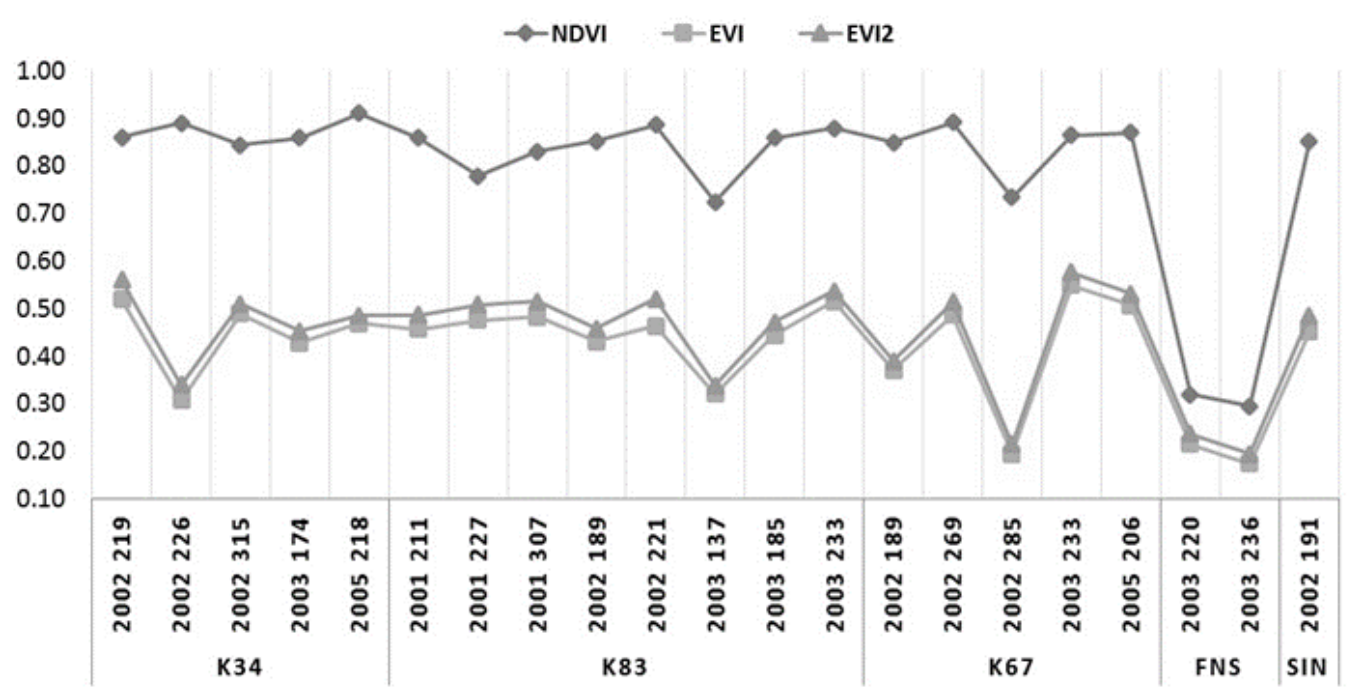

Figura 2: Comportamento dos índices de vegetação NDVI, EVI e EVI2 do sensor Hyperion nas torres.

O comportamento observado permite inferir que, para analisar o sequestro florestal de carbono em áreas de floresta, os melhores resultados foram obtidos com os índices EVI e EVI2. Além disso, pode-se afirmar que em áreas com menor densidade vegetal, qualquer um dos índices testados (NDVI, EVI e EVI2) apresentam bons resultados.

Nas análises estatísticas, o EVI respondeu tão bem quanto o EVI2 nos pontos de localização das torres. Dessa forma, pode-se adotar na estrutura do modelo de sequestro florestal de carbono, tanto um índice quanto, o outro. Para fins de comparação com outros índices espectrais de vegetação, seria mais interessante utilizar o EVI2. 
da Silva, S.C.P; Baptista, G.M.D..

Ao adotar o NDVI como variável independente e os demais índices (EVI e EVI2) como variáveis dependentes, pode-se dizer que existe correlação positiva de grau forte $(\mathrm{r}=0,762)$, entre os índices. O coeficiente de determinação foi 0,581 para o EVI e 0,582 para o EVI2 (Figura 3).

$\mathrm{Na}$ análise espectral obtidos, a partir do pixel de localização das torres micrometeorológicas, a correlação entre os índices NDVI e (EVI e EVI2) foi r=0,7622. O teste de hipótese indicou uma correlação estatisticamente significativa com uma confiança de $95 \%$.
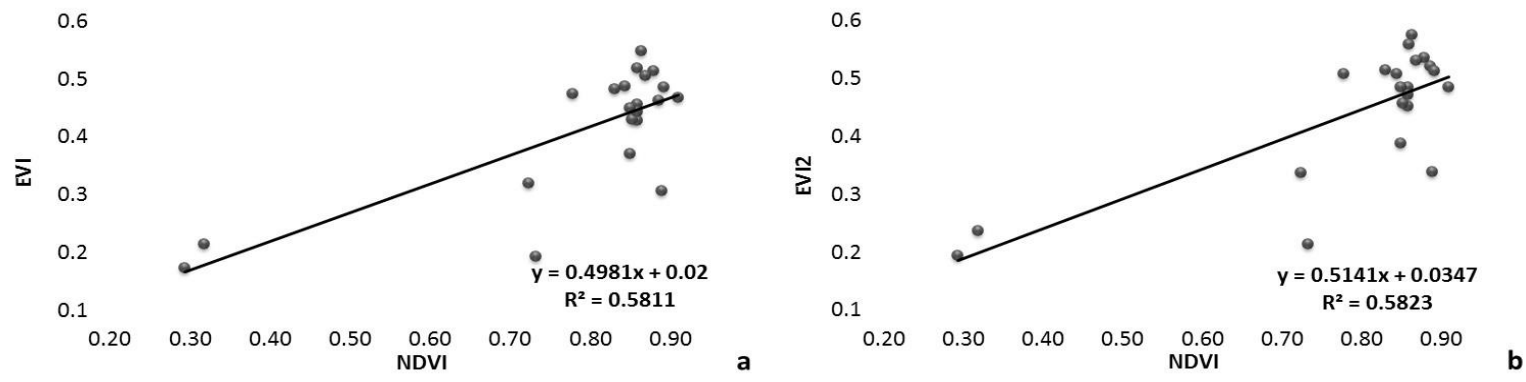

Figura 3: Relação linear entre os índices de vegetação NDVI com os índices a) EVI e b) EVI2.

\subsection{Análise pontual do sequestro florestal de carbono com CO2flux, CO2fluxEVI e CO2fluxEVI2}

Os resultados fazem referência às relações estatísticas entre as informações obtidas com a aplicação dos índices espectrais (CO2flux, CO2fluxEVI e CO2fluxEVI2) e as informações de campo da concentração (ppm) e fluxo $\left(\mathrm{mol} \cdot \mathrm{m}^{-2} \cdot \mathrm{s}^{-1}\right)$ de $\mathrm{CO}_{2}$.

A análise de regressão das variáveis verificadas a partir do coeficiente de determinação ajustou os modelos CO2flux, CO2fluxEVI e CO2fluxEVI2, a uma função não-linear com distribuição polinomial. De acordo com Milone (2004), essa função é perfeitamente aceita, quando o conjunto de dados não se ajustam a uma reta, assim, convém testar as funções não-lineares, de grau maior que um.

Para averiguar a normalidade dos dados, utilizou-se o teste estatístico de Shapiro-Wilk ou teste W (Tabela 4). Pela regra de decisão, o teste de normalidade para a maioria das variáveis analisadas ao nível de significância de 5\% não apresentaram normalidade na sua distribuição. Dessa forma, para análises estatísticas foram utilizados também, os testes não paramétricos, uma vez que, as amostras nesse estudo são relativamente pequenas, devido insuficiência de dados coincidentes entre as variáveis espectrais e as obtidas em campo. 
Tabela 4: Teste de Normalidade de Shapiro-Wilk.

\begin{tabular}{|c|c|c|c|c|}
\hline \multicolumn{2}{|c|}{ Teste de Normalidade de Shapiro-Wilk } & $\mathbf{N}$ & $\mathbf{W}_{\text {CAL }}$ & $P$ \\
\hline & $\mathrm{CO}_{2} f l u x$ & 21 & 0.5431 & 0.0062 \\
\hline & $\mathrm{CO}_{2} f l u x E V I$ & 21 & 0.8696 & 0.0100 \\
\hline & $\mathrm{CO}_{2}$ fluxEVI2 & 21 & 0.8659 & 0.0099 \\
\hline \multirow{2}{*}{1 hora } & Perfis de $\mathrm{CO}_{2}$ & 21 & 0.8319 & 0.0095 \\
\hline & $\mathrm{CO}_{2}$ no topo da Torre & 21 & 0.9567 & 0.4639 \\
\hline \multirow{2}{*}{2 horas } & Perfis de $\mathrm{CO}_{2}$ & 21 & 0.8052 & 0.0092 \\
\hline & $\mathrm{CO}_{2}$ no topo da Torre & 21 & 0.8052 & 0.0092 \\
\hline
\end{tabular}

A análise estatística que avalia o modelo com melhor ajuste para a verificação do sequestro florestal de carbono, tomando as áreas que correspondem as coordenadas geográficas das torres micrometeorológicas, com leitura de 1 pixel na imagem Hyperion, são explicados numa associação não-linear com os dados de concentração e fluxo de $\mathrm{CO}_{2}$ obtidos nas torres.

\subsubsection{Médias de perfis de concentração de $\mathrm{CO}_{2}(\mathrm{ppm})$ ao longo da torre}

O melhor ajuste com os dados analisados ao longo da torre foi verificado entre o CO2flux e a concentração de $\mathrm{CO}_{2}$ (ppm), que apresentou coeficiente de determinação 0,5077 para as observações a cada 2 horas. Quanto aos modelos, $\mathrm{CO}_{2}$ fluxEVI e $\mathrm{CO}_{2}$ fluxEVI2, o ajustamento da curva apresentou coeficientes de determinação 0,3409 e 0,3084, para as observações a cada 1 hora, respectivamente (Figura 4).

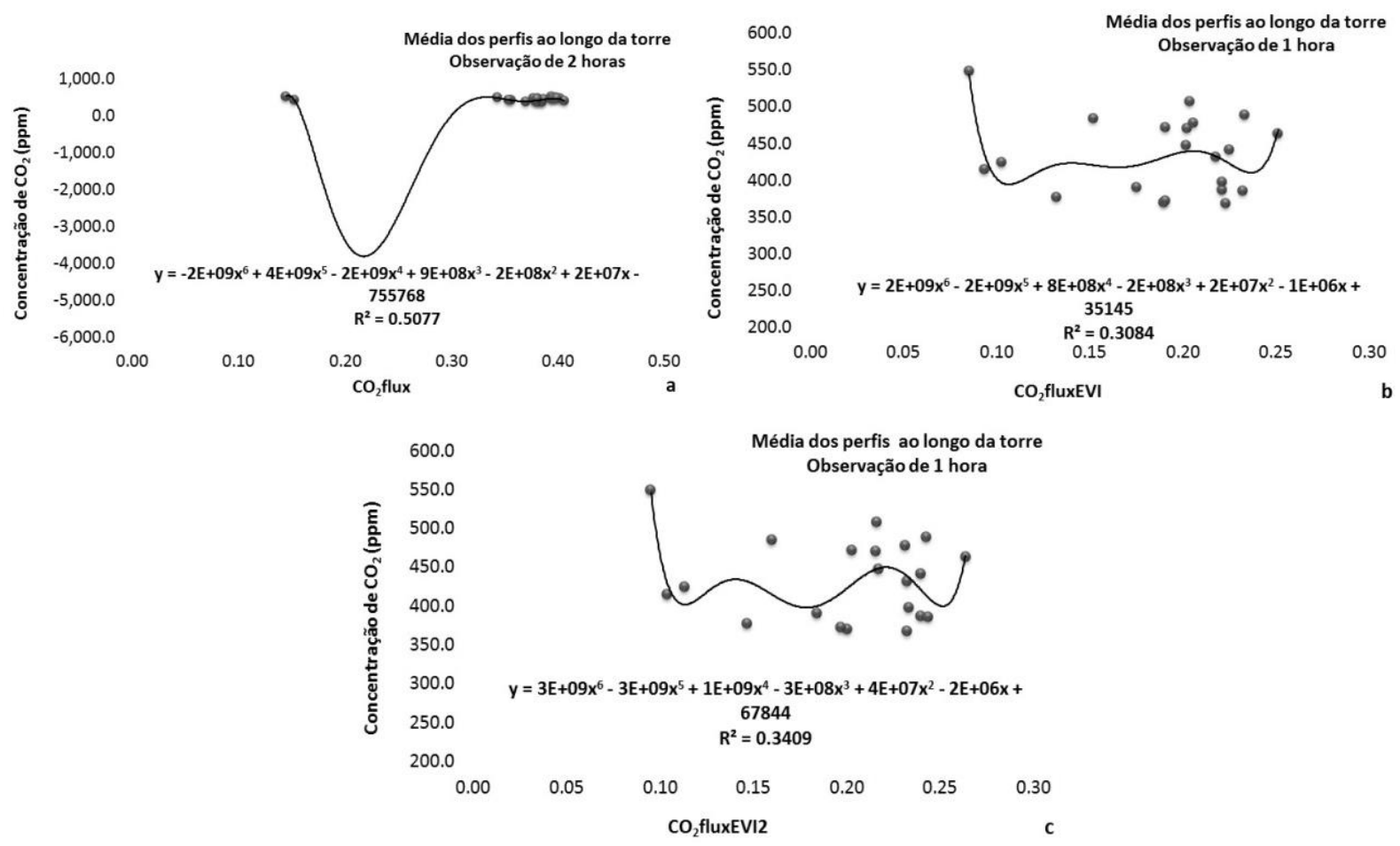

Figura 4: Ajustes dos modelos $\mathrm{CO}_{2}$ flux, $\mathrm{CO}_{2}$ fluxEVI e $\mathrm{CO}_{2}$ fluxEVI2, com a concentração (ppm) ao longo das torres. 
da Silva, S.C.P; Baptista, G.M.D..

\subsubsection{Médias de perfis de concentração de $\mathrm{CO}_{2}(\mathrm{ppm})$ no topo das torres}

De acordo com os resultados analisados no topo das torres foi possível verificar que o $\mathrm{CO}_{2}$ flux se relaciona melhor com a concentração de $\mathrm{CO}_{2}$ a cada 2 horas de observação, onde foi verificado o melhor ajustamento da curva, com os coeficientes de determinação 0,62. Os resultados entre os modelos $\mathrm{CO}_{2}$ fluxEVI e $\mathrm{CO}_{2}$ fluxEVI2 foram similares, apresentando coeficientes de determinação 0,4798 para $\mathrm{CO}_{2}$ fluxEVI e 0,4692 para o $\mathrm{CO}_{2}$ fluxEVI2 (Figura 5).

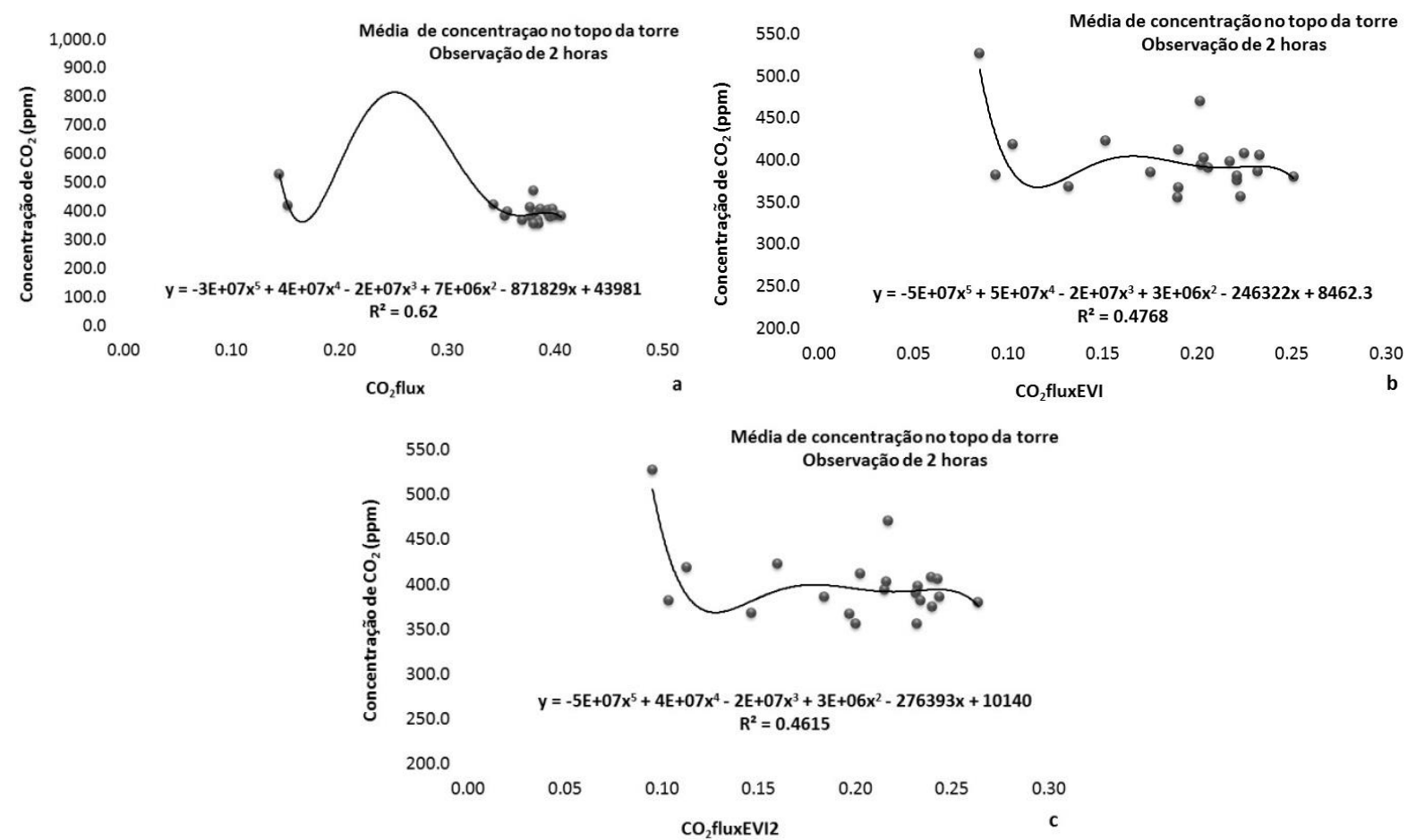

Figura 5: Ajustes do $\mathrm{CO}_{2}$ flux, $\mathrm{CO}_{2}$ fluxEVI e $\mathrm{CO}_{2}$ fluxEVI2 com a concentração (ppm) no topo das torres.

\subsubsection{Fluxo de $\mathrm{CO}_{2}\left(\mathrm{~mol} \mathrm{~m}^{-2} . \mathrm{s}^{-1}\right)$ com os índices de sequestro de carbono}

Na modelagem para observações obtidas com médias a cada 2 horas verificou-se que o $\mathrm{CO}_{2}$ flux apresenta ajustamento melhor com os dados de fluxo $\left(\mathrm{mol} \cdot \mathrm{m}^{-2} \cdot \mathrm{s}^{-1}\right)$, apresentando coeficiente de determinação 0,8673 , com relação aos outros dois modelos $\mathrm{CO}_{2}$ fluxEVI e $\mathrm{CO}_{2}$ fluxEVI2, cujos coeficientes de determinação foram, respectivamente, 0,5907 e 0,5749 (Figura 6).

$\mathrm{Na}$ relação entre modelagem de sequestro florestal de carbono e dados de concentração de $\mathrm{CO}_{2}$ (ppm), os resultados mostraram que as medidas de $\mathrm{CO}_{2}$ no topo das torres foram mais eficientes para as associações com medidas espectrais, do que as medições de $\mathrm{CO}_{2}$ realizadas ao longo da torre. Enquanto que, para os dados de fluxo, a melhor modelagem foi para observações cada 2 horas com $\mathrm{CO}_{2}$ flux.

As correlações entre as variáveis mensuradas foram realizadas pelos coeficientes de Pearson, de Spearman (para dados não paramétricos) e pela correlação canônica.

Pela matriz de correlação de Pearson pode-se inferir que o $\mathrm{CO}_{2}$ flux, mesmo apresentando o problema de saturação, se correlaciona melhor com as medidas de $\mathrm{CO}_{2}$ obtidas em campo. $\mathrm{O}$ $\mathrm{CO}_{2}$ flux apresentou uma forte correlação $(\mathrm{r}=-0,641)$ com a concentração de $\mathrm{CO}_{2}(\mathrm{ppm})$ medidos no topo das torres e $(\mathrm{r}=-0,663) \mathrm{com}$ as medidas de fluxo de $\mathrm{CO}_{2}\left(\mathrm{~mol} \cdot \mathrm{m}^{-2} \cdot \mathrm{s}^{-1}\right)$, enquanto que os modelos $\mathrm{CO}_{2}$ fluxEVI e $\mathrm{CO}_{2}$ fluxEVI2 obtiveram correlações moderadas. Para todas as 
correlações de Pearson, o teste de hipóteses indicou que as correlações analisadas são estatisticamente significativas (Tabela 5).

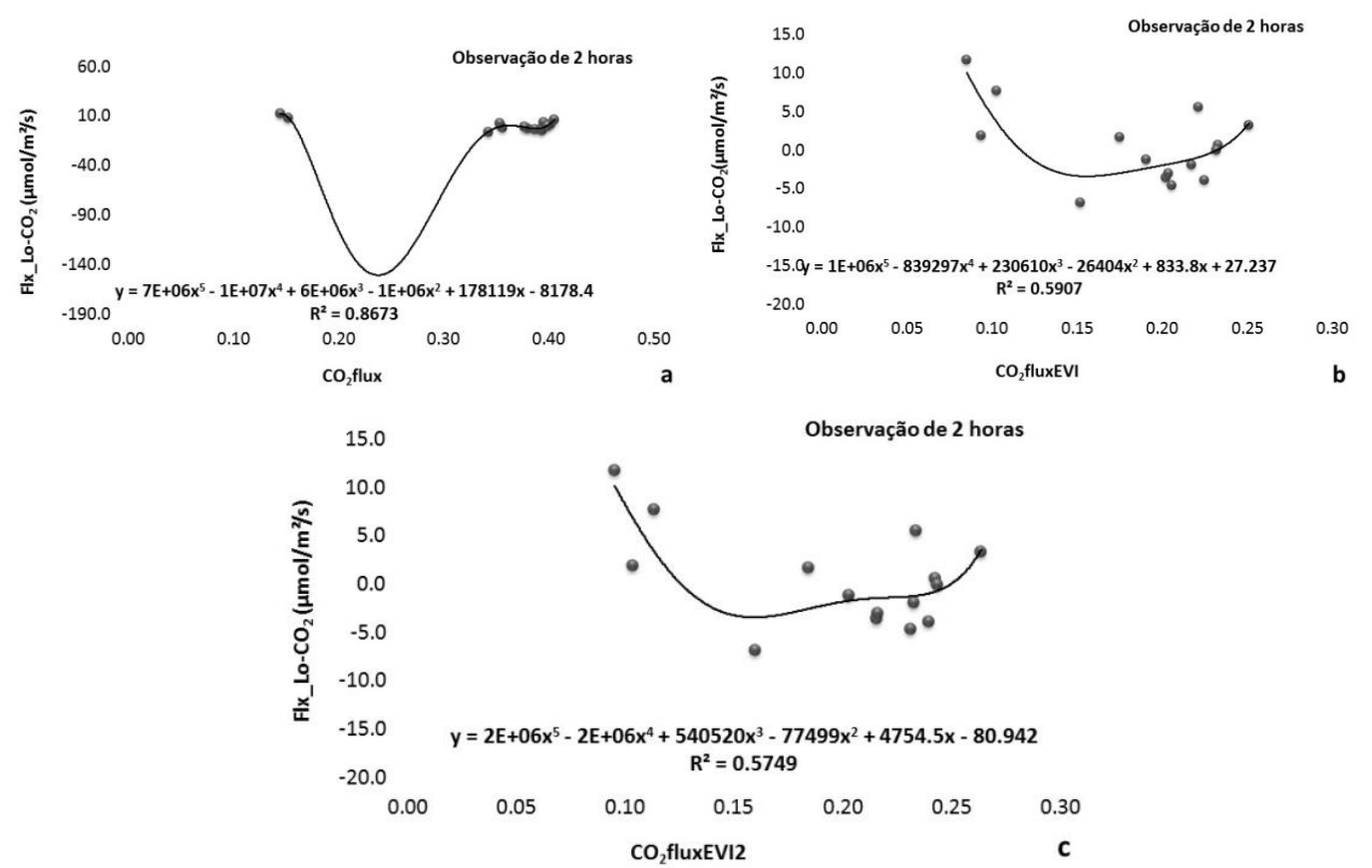

Figura 6: Ajustes do $\mathrm{CO}_{2}$ flux, $\mathrm{CO}_{2}$ fluxEVI e $\mathrm{CO}_{2}$ fluxEVI2 com dados de fluxo com média de observações de 2 horas.

Tabela 5: Matriz de Correlação de Pearson (r).

\begin{tabular}{|c|c|c|c|c|c|c|c|c|c|}
\hline $\begin{array}{r}\text { Correlação de } \\
\text { Pearson } \\
(r)\end{array}$ & $\mathrm{CO}_{2}$ flux & $\mathrm{CO}_{2}$ fluxEVI & $\mathrm{CO}_{2}$ fluxEVI2 & $\begin{array}{c}\text { Perfis } \\
\mathrm{CO}_{2}(1 \mathrm{~h})\end{array}$ & $\begin{array}{c}\text { Perfis } \\
\mathrm{CO}_{2}(2 \mathrm{~h})\end{array}$ & $\begin{array}{c}\text { Topo } \\
\text { Torre }(1 \\
\text { h) }\end{array}$ & $\begin{array}{l}\text { Topo } \\
\text { Torre }(2 \\
\text { h) }\end{array}$ & $\begin{array}{c}\text { Fluxo } \\
\mathrm{CO}_{2}(1 \mathrm{~h})\end{array}$ & $\begin{array}{c}\text { Fluxo } \\
\mathrm{CO}_{2}(2 \mathrm{~h})\end{array}$ \\
\hline $\mathrm{CO}_{2}$ flux & 1.00 & & & & & & & & \\
\hline $\mathrm{CO}_{2}$ fluxEVI & 0.730 & 1.00 & & & & & & & \\
\hline $\mathrm{CO}_{2}$ fluxEVI2 & 0.729 & 0.997 & 1.00 & & & & & & \\
\hline Perfis $\mathrm{CO}_{2}(1 \mathrm{~h})$ & -0.343 & -0.151 & -0.135 & 1.00 & & & & & \\
\hline Perfis $\mathrm{CO}_{2}(2 \mathrm{~h})$ & -0.220 & -0.059 & -0.057 & 0.888 & 1.00 & & & & \\
\hline $\begin{array}{r}\mathrm{CO}_{2} \text { no Topo } \\
\text { Torre }(1 \mathrm{~h})\end{array}$ & -0.599 & -0.342 & -0.337 & 0.614 & 0.690 & 1.00 & & & \\
\hline $\begin{array}{r}\mathrm{CO}_{2} \text { no Topo } \\
\text { Torre }(2 \mathrm{~h})\end{array}$ & -0.641 & -0.417 & -0.407 & 0.727 & 0.683 & 0.924 & 1.00 & & \\
\hline Fluxo $\mathrm{CO}_{2}(1 \mathrm{~h})$ & -0.637 & -0.424 & -0.438 & -0.053 & -0.115 & 0.413 & 0.432 & 1.00 & \\
\hline Fluxo $\mathrm{CO}_{2}(2 \mathrm{~h})$ & -0.663 & -0.470 & -0.483 & -0.008 & -0.058 & 0.474 & 0.483 & 0.951 & 1.00 \\
\hline
\end{tabular}

As correlações descritas pelo coeficiente de Pearson são negativas, de grau forte entre as variáveis $\mathrm{CO}_{2}$ flux e as medidas de $\mathrm{CO}_{2}$ nas torres micrometeorológicas. Assim, quanto maior for a atividade fotossintética medida pelo $\mathrm{CO}_{2}$ flux, menor é a concentração (ppm) e a intensidade de fluxo (mol. $\left.\mathrm{m}^{-2} \cdot \mathrm{s}^{-1}\right)$ de $\mathrm{CO}_{2}$ tende a ser negativa na camada atmosférica próximo das torres.

Os modelos ajustados para os dados de concentração (ppm) indicam que 64\% da variação observada de $\mathrm{CO}_{2}$ flux, $41 \%$ de $\mathrm{CO}_{2}$ fluxEVI e $40 \%$ de $\mathrm{CO}_{2}$ fluxEVI2 são explicados pela quantidade de $\mathrm{CO}_{2}$ absorvido pela vegetação no momento da passagem do sensor Hyperion, padronizados com média de intervalos a cada duas horas. Enquanto que, para os dados de fluxo $\left(\right.$ mol.m ${ }^{-2} \cdot \mathrm{s}^{-1}$ ) essa variação mostra $66 \%$ de $\mathrm{CO}_{2}$ flux, $47 \%$ de $\mathrm{CO}_{2}$ fluxEVI e $48 \%$ de $\mathrm{CO}_{2}$ fluxEVI são explicados pela intensidade de assimilação e emissão de $\mathrm{CO}_{2}$ atmosférico, no momento da passagem do sensor, onde se encontravam as cinco torres micrometeorológicas. 
da Silva, S.C.P; Baptista, G.M.D..

Quando se analisa a correlação pelo coeficiente de Spearman (rs), os resultados apontam para correlações fracas entre as variáveis, entretanto, os dados indicam que as associações são do tipo não-lineares e corroboram com os coeficientes de Pearson, indicando também correlações negativas.

$\mathrm{Na}$ análise de correlação canônica, as variáveis espectrais foram consideradas um grupo (Y), enquanto que as variáveis mensuradas diretamente nas torres, o outro grupo (X). Na tabela 6 verifica-se que a primeira correlação foi de $\mathrm{R}$ Canônico 0,8350 , representando a melhor correlação possível entre qualquer combinação linear das variáveis espectrais com as variáveis de medição de $\mathrm{CO}_{2}$ direta na torre. A estatística $\mathrm{R}$ Canônico expressa a magnitude do relacionamento entre os dois conjuntos de variáveis.

Tabela 6: Resultados da Correlação Canônica.

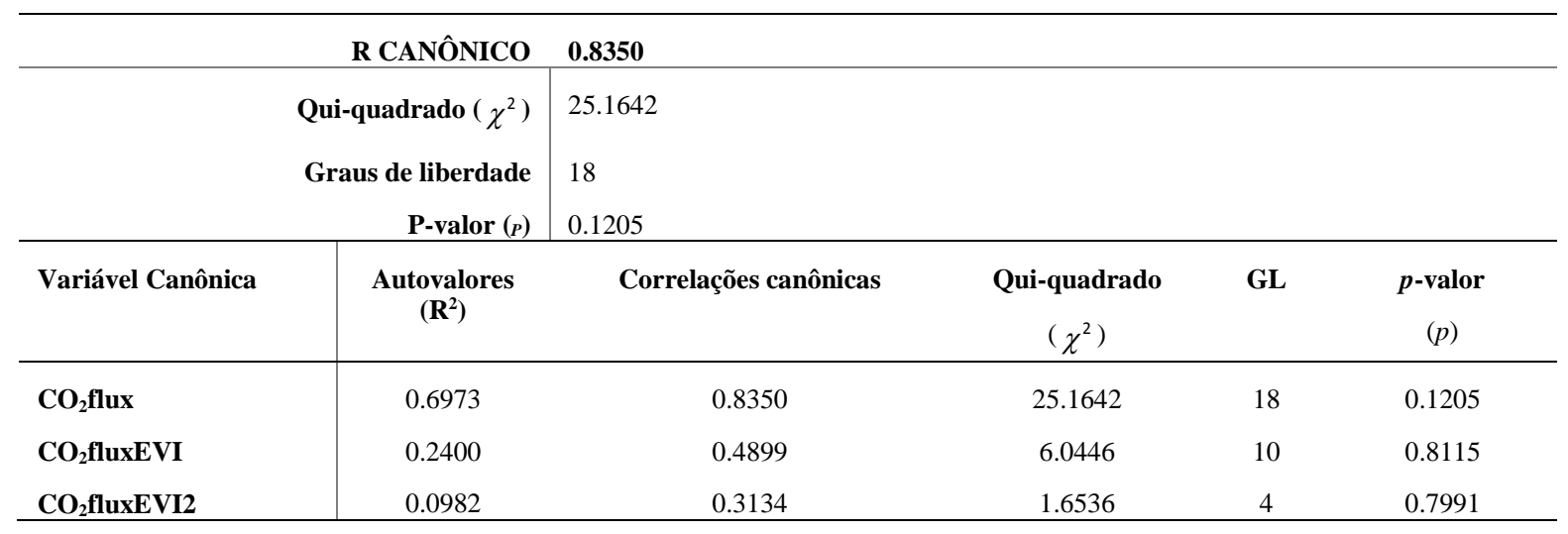

Entretanto, quando se analisa cada associação pela matriz de correlação canônica, verifica-se que as correlações são negativas e moderadas entre as variáveis e pelo menos seis associações são estatisticamente significativas (Tabela 7).

Tabela 7: Matriz de correlação entre as variáveis espectrais e as mensurações nas torres.

\begin{tabular}{|c|c|c|c|c|c|c|}
\hline \multirow{2}{*}{$\frac{\text { Correlação }(r s)}{\text { Perfis de } \mathrm{CO}_{2}(1 \mathrm{~h})}$} & \multicolumn{2}{|c|}{$\mathrm{CO}_{2}$ flux } & \multicolumn{2}{|c|}{$\mathrm{CO}_{2}$ fluxEVI } & \multicolumn{2}{|c|}{$\mathrm{CO}_{2}$ fluxEVI2 } \\
\hline & -0.342 & ns & -0.151 & ns & -0.134 & ns \\
\hline Perfis de $\mathrm{CO}_{2}(2 \mathrm{~h})$ & -0.220 & $\mathrm{~ns}$ & -0.059 & ns & -0.057 & ns \\
\hline $\mathrm{CO}_{2}$ no Topo da Torre $(1 \mathrm{~h})$ & -0.599 & $(p<0.01)$ & -0.343 & ns & -0.338 & ns \\
\hline $\mathrm{CO}_{2}$ no Topo da Torre (2 h) & -0.642 & $(p<0.01)$ & -0.417 & ns & -0.407 & $\mathrm{~ns}$ \\
\hline Fluxo de $\mathrm{CO}_{2}(1 \mathrm{~h})$ & -0.637 & $(p<0.01)$ & -0.400 & ns & -0.414 & ns \\
\hline Fluxo de $\mathrm{CO}_{2}(2 \mathrm{~h})$ & -0.660 & $(p<0.01)$ & -0.443 & $(p<0.01)$ & -0.456 & $\left({ }_{p}<0.01\right)$ \\
\hline
\end{tabular}

Resultados similares de $\mathrm{CO}_{2}$ flux foram encontrados por Rahman et al. (2000; 2001), entretanto os autores apresentam uma relação linear, com um valor de $\mathrm{R}^{2}$ de 0,78 , entre os dados de $\mathrm{CO}_{2}$ flux e o fluxo de $\mathrm{CO}_{2}$ nas torres utilizando o sensor AVIRIS, resultando no mapeamento de fluxos fotossintéticos numa paisagem de floresta boreal. Fuentes et al. (2006) apresentaram um ajuste linear com coeficiente de determinação 0,96, entre os índices PRI e NDVI, usando o sensor AVIRIS e as medidas de fluxo de torres num ecossistema de semiárido no sul da Califórnia (Estados Unidos).

As correlações mais baixas nesse estudo, quando comparadas com os resultados de Rahman et al. (2000; 2001) e Fuentes et al. (2006) podem ser explicadas por dois fatores: tipo de sensor utilizado e a variabilidade de paisagens (naturais e antrópicas). 
De acordo com Baptista (2003), as análises espectrais obtidas com o Hyperion apresentam menor coeficiente de correlação, pois são obtidos a $705 \mathrm{~km}$ de altitude, o que pode apresentar interferências acima da troposfera. Além disso, os espectros do AVIRIS são menos ruidosos, o que permitem correlações superiores a $85 \%$.

Para Cerqueira e Franca-Rocha (2007) existiam diferenças significativas entre os tipos de vegetação no Bioma Caatinga, por exemplo, quando são analisadas com o $\mathrm{CO}_{2}$ flux. Wylie et al. (2007) sugerem que na pastagem são necessárias séries temporais mais longas para fornecer estimativas precisas do estado ou tendências nos fluxos de $\mathrm{CO}_{2}$ nos ambientes.

Objetivando testar a similaridade estatística entre os modelos de sequestro florestal de carbono, aplicou-se o teste não paramétrico de Wilcoxon-Mann-Whitney ou Teste U. Na análise, verificou-se que não há diferença entre as informações obtidas a partir dos índices espectrais na imagem Hyperion e nas informações de campo de concentração (ppm) e fluxo $\left(\mathrm{mol} . \mathrm{m}^{-2} \cdot \mathrm{s}^{-1}\right)$ de $\mathrm{CO}_{2}$ medido nas torres, existindo, portanto, similaridade entre as variáveis analisadas.

Da mesma forma com os resultados encontrados nesse estudo para dados Hyperion, foram satisfatórias as similaridades entre dados espectrais do sensor MERIS e MODIS e dados de fluxo de $\mathrm{CO}_{2}$ torres micrometeorológicas em florestas, que são apontadas no trabalho de Harris e Dash (2010). Em culturas agrícolas, também vem sendo estudados as correlações entre estoque e sequestro de carbono, que apresentaram potencialidade com uso de imagens Quickbird e Landsat (Coltri et al., 2009).

A modelagem pontual de sequestro florestal de carbono para as coordenadas geográficas onde estão localizadas as torres na Amazônia Brasileira pode ser realizada a partir do índice $\mathrm{CO}_{2}$ flux, tanto com os dados de concentração de $\mathrm{CO}_{2}$ (ppm) medidos no topo das torres, quanto, com os dados de fluxo $\left(\mathrm{mol} \cdot \mathrm{m}^{-2} \cdot \mathrm{s}^{-1}\right)$, pois ambas associações possuem significância e similaridades estatística com os dados do sensor Hyperion.

\section{Conclusões}

A modelagem pontual de sequestro florestal de carbono para as áreas naturais e antrópicas, pode ser realizada pelo índice $\mathrm{CO}_{2}$ flux. Entretanto, para análises consistentes dos índices espectrais verificou-se que, as etapas que antecedem o processamento do $\mathrm{CO}_{2}$ flux, $\mathrm{CO}_{2}$ fluxEVI e $\mathrm{CO}_{2}$ fluxEVI2 são de suma importância e devem ser cuidadosamente processadas, uma vez que o sensor Hyperion possui imagens mais ruidosas, comparadas a outros sensores hiperespectrais.

As correlações entre as variáveis mensuradas são inversamente proporcionais indicando maior atividade fotossintética medida pelo $\mathrm{CO}_{2}$ flux, quando a concentração (ppm) é menor e a intensidade de fluxo $\left(\mathrm{mol} \cdot \mathrm{m}^{-2} \cdot \mathrm{s}^{-1}\right)$ é negativo na camada atmosférica.

Medidas diretas de $\mathrm{CO}_{2}(\mathrm{ppm})$ no topo das torres são mais eficientes para a correlação com índices espectrais, do que as medições coletadas ao longo da torre. Contudo, os melhores ajustes para o $\mathrm{CO}_{2}$ flux foram apresentados para a associação com dados de fluxo $\left(\mathrm{mol} . \mathrm{m}^{-2} \cdot \mathrm{s}^{-1}\right)$.

\section{AGRADECIMENTOS}

À Fundação de Amparo à Pesquisa do Estado do Amazonas (FAPEAM), instituição financiadora. Ao Programa de Pós-Graduação do Instituto de Geociências da Universidade de Brasília (UnB), ao INPA (Instituto Nacional de Pesquisas da Amazônia) pela parceria junto ao Programa LBA

Bol. Ciênc. Geod., sec. Artigos, Curitiba, v. 21, nº 2, p.354-370, abr-jun, 2015. 
da Silva, S.C.P; Baptista, G.M.D..

(Large Scale Biosphere-Atmosphere Experiment in Amazonia), a Universidade Federal do Rondônia (UNIR) - Campus Ji-Paraná e ao IBAMA (Instituto Brasileiro do Meio Ambiente e dos Recursos Naturais Renováveis), no apoio logístico com dados de campo.

\section{REFERÊNCIAS BIBLIOGRÁFICAS}

Aguiar, R. G.; Randow, C. V.; Filho, N. P.; Manzi, A. O.; Aguiar, L. J. G.; Cardoso, F. L. Fluxos de massa e energia em uma floresta tropical no sudoeste da Amazônia. Revista Brasileira de Meteorologia, v. 21, n. 3b, p. 248-257, 2006.

Asner, G. P.; Carlson, K. M.; Martin, R. E. Substrate age and precipitation effects on Hawaiian forest canopies from spaceborne imaging spectroscopy. Remote Sensing of Environment, v. 98 p. 457-467, 2005.

Baptista, G. M. M. Validação da modelagem de sequestro de carbono para ambientes tropicais de cerrado, por meio de dados AVIRIS e HYPERION. In: XI SBSR, Belo Horizonte, Brasil, 0510 abril 2003. Anais... São José dos Campos: INPE, p. 1037-1044, 2003.

Box, E. O.; Holben, N. B.; Kalb, V. Accuracy of the AVHRR Vegetation Index as a predictor of biomass, primary productivity and net CO2 flux. Vegetatio v. 80, 71-89, 1989.

Carlson, T. N.; Ripley, D. A. On the relation between NDVI, fractional vegetation cover, and leaf area index. Remote Sensing of Environment, v. 62, p. 241-252, 1997.

Carvalho Júnior, O. A.; Carvalho, A. P. F.; Meneses, P. R.; Guimarães, R. F. Classificação e eliminação dos ruídos em imagens hiperespectrais pela análise sequencial da transformação por fração de ruído mínima. Revista Brasileira de Geofísica, v. 20, n. 1, p. 31-41, 2002.

Cerqueira, D. B.; Rocha, W. F.; Relação entre tipos de vegetação e fluxo de CO2 no Bioma Caatinga: Estudo de caso em Rio de Contas - BA. In: Simpósio Brasileiro de Sensoriamento Remoto, XIII, Florianópolis, 2007. Anais... São José dos Campos: INPE, 2007. p. 2413-2419.

Coltri, P. P.; Ramirez, G. M; Walter, M K. C.; Zullo Júnior, J.; Pinto, H. S.; Nascimento, C. R.; Gonçalves, R. R. V. Utilização de índices de vegetação para estimativas não destrutivas da biomassa, estoque e sequestro de carbono do cafeeiro arábica. In: Simpósio Brasileiro de Sensoriamento Remoto, XIV, Natal, 2009. Anais... São José dos Campos: INPE, 2009. p. 121128.

Datt, B.; Mcvicar, T. R.; Van Niel, T. G.; Jupp, D. L. B.; Pearlman, J. S. Preprocessing EO-1 Hyperion Hyperspectral Data to Support the Application of Agricultural Indexes. Ieee Transactions On Geoscience And Remote Sensing, v. 41, n. 6, 2003.

EO-1 User Guide. Version 2.3 - 2003, Supporting materials are available. Disponível em: <http://eo1.gsfc.nasa.gov>. Acesso em:10 set. 2012.

Fuentes, D. A.; Gamon, J. A.; Cheng, Y; Claudio, H. C.; Qiu, H.; Mao, Z.; Sims, D. A,; Rahman, A. F.; Oechel, W.; Luo, H. Mapping carbon and water vapor fluxes in a chaparral ecosystem using vegetation indices derived from AVIRIS. Remote Sensing of Environment, v. 103, p. 312323, 2006.

Galvão, L. S.; Formaggio, A. R.; Tisot, D. A. Discriminação de variedades de cana-de-açúcar com dados hiperespectrais do sensor Hyperion/EO-1. Revista Brasileira de Cartografia, v. 57, n. 1, p. 7-14, 2005. 
Gamon, J. A.; Serrano, L.; Surfus, J.S., The photochemical reflectance index: an optical indicator of photosynthetic radiation use efficiency across species, functional types, and nutrient levels. Oecologica, v. 112, p. 492-501, 1997.

Huete, A. R. A soil-adjusted vegetation index (SAVI). Remote Sensing of Environment, v. 25, p. 295-309, 1988.

Huete, A. R., Didan, K., Miura, T., Rodriguez, E. P., Gao, X.; Ferreira, L. G. Overview of the radiometric and biophysical performance of the MODIS vegetation indices. Remote Sensing of Environment, v. 83, p. 195-213, 2002.

Huete, A.; Liu, H. Q.; Batchily, K.; Van Leeuwen, W.J.D.A. A comparison of vegetation indices over a global set of TM images for EOS-MODIS. Remote Sensing of Environment, v. 59, p. 440451, 1997.

Jensen, J. R. Sensoriamento Remoto do Ambiente: uma perspectiva em recursos terrestres; tradução José Carlos Neves Epiphanio (coordenador) ... [et al.]. Parênteses: São Paulo, 2009.

Jiang, Z.; Huete, A. R.; Didan, K.; Miura, T. Development of a two-band enhanced vegetation index without a blue band. Remote Sensing of Environment, v.112, p. 3833-3845, 2008.

Milone, G. Estatística: Geral e Aplicada. São Paulo: Thomson Learning, 2004.

Nascimento, R. L. Análise comparativa dos componentes do saldo de radiação em áreas de pastagem e floresta na Amazônia. 2012. 78p. Dissertação (Mestrado) - Universidade Federal de Campina Grande, 2012.

Ponzoni, F. J.; Shimabukuro, Y. E. Sensoriamento Remoto no Estudo da Vegetação. São José dos Campos, SP: A. Silva Vieira Ed., 2010.

Rahman, A. F.; Gamon, J. A.; Fuentes, D. A.; Roberts, D. A.; Prentiss, D. Modeling spatially distributed ecosystem flux of boreal forest using hyperspectral indices from AVIRIS imagery. Journal of Geophysical Research, v. 106, n. D24, p. 33,579-33,591, 2001.

Rahman, A.F.; Gamon, J.A.; Fuentes, D.A.; Roberts, D.; Prentiss, D.; Qiu, H. Modeling CO2 flux of boreal forests using narrow-band indices from AVIRIS imagery. In: AVIRIS Workshop. Proceedings... JPL/NASA, Pasadena, California, 2000.

Rouse, J. W.; Haas, R.H., Schell, J.A.; Deering, D.W., "Monitoring Vegetation Systems in the Great Plains with ERTS". In: ERTS-1 Symposium. Proceedings... NASA, United States, n. 3. p. 309-317, 1973.

Schramm, V. F.; Vibrans, A. C. Uso de imagens hiperespectrais (EO-1 Hyperion) para detalhamento da detecção das formações florestais na bacia do Itajaí. Dynamics Revista TecnoCientífica, v.13, n.1, p. 59-69, 2007.

Souza, A. A. Estudo de Fitofisionomias de Cerrado com Dados de Sensor Hyperion/EO-1. 2009. 120p. Dissertação (Mestrado) - INPE, São José dos Campos, 2009.

Wylie, B. K.; Fosnight, E. A.; Gilmanov, T. G; Frank, A. B.; Morgan, J. A.; Haferkamp, M. R.; Meyers, T. P. Adaptive data-driven models for estimating carbon fluxes in the Northern Great Plains. Remote Sensing of Environment, v.106, p. 399-413, 2007.

Recebido em Novembro de 2014. Aceito em Abril de 2015. 


\title{
RELAÇÃO ENTRE O ÂNGULO DE VISADA E A ESTIMATIVA DA POTÊNCIA RADIATIVA DO FOGO
}

\author{
Relationship between the viewing angle and the Fire Radiative Power estimation
}

\author{
Guilherme Augusto Verola Mataveli ${ }^{1}$ \\ Gabriel Pereira ${ }^{2}$ \\ Elisabete Caria Moraes 1 \\ Bruno Silva Oliveira ${ }^{1}$ \\ Francielle da Silva Cardozo ${ }^{1}$ \\ 1 Instituto Nacional de Pesquisas Espaciais - INPE \\ Caixa Postal 515 - 12227-010 - São José dos Campos - SP, Brasil \\ Email: mataveli@dsr.inpe.br; bete@dsr.inpe.br; bruno.so@dsr.inpe.br, cardozo@dsr.inpe.br \\ 2 Universidade Federal de São João del- Rei - UFSJ \\ Departamento de Geociências. Rodovia BR-494 - km 194 - 196 \\ São João del Rei - MG, Brasil. \\ Email: pereira@ufsj.edu.br
}

\section{Resumo:}

As queimadas atingem grandes áreas, constituindo-se como um agente modelador dos ecossistemas e contribuem para o acúmulo de gases e aerossóis na atmosfera. Atualmente, o sensoriamento remoto é a principal fonte de dados para estudar as queimadas devido à aquisição de dados globais com uma periodicidade constante. No entanto, são necessárias mais informações sobre as queimadas além da sua localização espacial, dentre elas a biomassa queimada. O método mais utilizado para isso atualmente é derivado da Potência Radiativa do Fogo (FRP), já que a energia emitida como radiação eletromagnética durante a combustão pode ser diretamente relacionada com a biomassa queimada. Contudo, alguns fatores introduzem erros nas estimativas de FRP, como o ângulo de visada. Assim, para avaliar a influência dessa variável na FRP foi realizado um experimento de combustão em pequena escala utilizando como biomassa a palha da cana-de-açúcar. Ainda, foi determinado o coeficiente de biomassa queimada para a cana-de-açúcar. As estimativas obtidas permitiram concluir que a FRP diminui com o aumento do ângulo de visada, e, sendo assim, o ângulo de visada foi considerado no coeficiente de biomassa queimada. Pretende-se futuramente empregar os resultados encontrados para estimar a biomassa queimada e suas emissões provenientes da queimada pré-colheita da cana-de-açúcar.

Palavras-chave: Queimadas; Potência Radiativa do Fogo; Ângulo de Visada; Experimento de Combustão em Pequena Escala.

\footnotetext{
Abstract:

Fire affects large areas around the world, acting as a modeler of ecosystems and contributing to the accumulation of gases and aerosols in the atmosphere. Nowadays, remote sensing is the main source of data for studying fires, due to the possibility of acquiring global data with constant frequency. However, it is necessary to obtain more information about fires besides the spatial
} 
location, such as the amount of biomass burning. Currently, the most widely used method to estimate biomass burning is derived from Fire Radiative Power (FRP), on the assumption that energy emitted as electromagnetic radiation during combustion could be directly related to biomass burning. However, some factors can introduce errors in FRP, such as viewing angle. To determine the influence of viewing angle in FRP, a small scale experiment was conducted using sugarcane straw as biomass. Still, it was determined the biomass burning coefficient for sugarcane. The results showed that FRP tends to decrease according to the increasing of the viewing angle, and, therefore, the viewing angle was considered for the determination of the biomass burning coefficient. It is intended in the future to apply the results in order to estimate biomass burning and emissions from sugarcane pre-harvest burning.

Keywords: Biomass Burning; Fire Radiative Power; Viewing Angle; Small-scale Combustion Experiment.

\section{Introdução}

A queima de biomassa compreende a combustão de todos os tipos de material orgânico (Ichoku et al., 2012) e representa uma importante fonte de emissão de aerossóis e gases traços para a atmosfera, influenciando, dessa forma, o clima, principalmente em escala regional, além de ser um fator introdutório de mudanças na paisagem local e regional. Desta forma, torna-se importante quantificá-la com o intuito de compreender seus impactos nos diferentes biomas e no clima (Schroeder et al., 2014). Quanto à sua origem, 90\% das queimadas são ocasionadas pelo homem e os $10 \%$ restantes são relacionados a acidentes ou causas naturais, como raios e combustão espontânea (Andreae e Merlet, 2001). Estima-se que entre 3547 e 3938 teragramas ( Tg) de biomassa seca são queimadas anualmente, sendo sua maior concentração em regiões de savana no continente africano (Lauk e Erb, 2009).

Durante muitas décadas, as estimativas de biomassa queimada eram feitas a partir de experimentos e medições in situ (Andreae e Merlet, 2001), contudo ao considerar um fenômeno dinâmico como as queimadas, a cobertura espacial e temporal desse tipo de abordagem é limitada. Nos últimos anos, com o avanço no sensoriamento remoto orbital, os dados provenientes de sensores orbitais se tornaram a principal fonte de dados para estimar a quantidade de biomassa queimada e as respectivas emissões de gases traços e aerossóis (Freitas et al., 2007; Ichoku et al., 2008; Hantson et al., 2013). Esta característica torna-se viável devido à aquisição de dados de forma sistemática e em nível global.

Tradicionalmente, a quantidade de biomassa queimada é estimada a partir da Equação 1 (Seiler e Crutzen, 1980).

$$
B Q=A \cdot B \cdot \alpha
$$

em que $B Q$ é a quantidade de biomassa queimada $(\mathrm{kg}), A$ é a área queimada $\left(\mathrm{km}^{2}\right), B$ é a biomassa disponível para queima $\left(\mathrm{kg} . \mathrm{km}^{-2}\right)$ e $\alpha$ é o fator de combustão.

A principal dificulade em estimar a biomassa queimada a partir da Equação 1 está nos termos da equação $A e B$, já que existem incertezas presentes nas estimativas de área queimada com o uso de produtos derivados de sensores orbitais e que podem prejudicar as estimativas de biomassa queimada (Van der Werf et al., 2006; Pereira et al., 2012).

Neste contexto, desenvolvem-se vários métodos para estimar a biomassa queimada (Freeborn et al., 2008). Um dos métodos mais utilizados atualmente para estimar a biomassa queimada é derivado da Potência Radiativa do Fogo (do inglês Fire Radiative Power, FRP) (Roberts et al., 
2005; Wooster et al., 2005; Freeborn et al., 2008; Vermote et al., 2009; Pereira et al., 2012). A FRP é definida como a taxa na qual a energia é emitida pelo fogo na forma de radiação (Wooster et al., 2003). Esse método baseia-se em Wooster (2002), que testou as relações entre a FRP e a biomassa queimada em um experimento de combustão em pequena escala, chegando à conclusão que existia de uma relação linear entre essas variáveis. Contudo, assim como na maioria das estimativas obtidas por sensoriamento remoto, deve-se atentar aos fatores que introduzem erros na estimativa da FRP e que, portanto, prejudicam sua precisão.

De acordo com Ichoku et al. (2012), entre as principais fontes de erro na estimativa da FRP podese citar o ângulo de visada. Com o aumento do ângulo de visada, o tamanho do pixel aumenta (Giglio et al., 2006) e, ainda, a precisão dos algoritmos de detecção de anomalias termais que originam os produtos de fogo ativo pode ser comprometida. Em um estudo preliminar, a diferença entre a FRP estimada no nadir e com um ângulo de visada de 40 graus foi de até $22 \%$ para uma mesma amostra de biomassa (Paugam et al., 2013).

Portanto, devido ao seu amplo uso pela comunidade científica não somente para estimar quantidade de biomassa queimada, mas também para a estimativa de gases traços e aerossóis associados à queima de biomassa e como dados de entrada em modelos ambientais e climatológicos (Xu et al., 2010), torna-se necessário compreender os erros causados pelo ângulo de visada na estimativa da FRP. Dentro desse contexto, o presente trabalho tem por objetivo analisar a influência do ângulo de visada na estimativa da FRP a partir de um experimento de combustão em pequena escala.

\section{Métodos para estimar a Potência Radiativa do Fogo}

Visando a maior compreensão do fenômeno das queimadas, Kaufman et al. (1996) introduziram o conceito de FRP, e posteriormente foi proposto que a estimativa da quantidade de energia emitida como radiação eletromagnética durante o processo de combustão seria capaz de ser diretamente relacionada com a quantidade de biomassa queimada (Wooster, 2002).

A FRP (em MWatts) pode ser estimada ao se conhecer a distribuição da temperatura no pixel, como é apresentado na Equação 2 (Kaufman et al., 1996).

$$
F R P=\varepsilon . \sigma \cdot \sum_{i=1}^{n} A_{n} T_{n}^{4}
$$

em que $\varepsilon$ é a emissividade, $\sigma$ é a constante de Stefan-Boltzmann $\left(5,67 \times 10^{-8} \mathrm{~J} \cdot \mathrm{s}^{-1} \cdot \mathrm{m}^{-2} \cdot \mathrm{K}^{-4}\right), A_{n}$ representa a área fracional da enésima componente termal $\left(\mathrm{m}^{2}\right)$ e $T_{n}$ é a temperatura da enésima componente $(\mathrm{K})$.

Porém, a estimativa da FRP a partir da Equação 2 apresenta dificuldades, uma vez que a queimada dificilmente ocorre em toda área de um pixel imageado por um sensor orbital, prejudicando, desta forma, o cálculo da área do componente fogo em cada pixel e a estimativa da temperatura do componente fogo, que apresentarão variações no subpixel (Eckman et al., 2010; Wooster et al., 2011).

Um dos primeiros métodos utilizados para caracterizar a temperatura e a área do componente fogo no subpixel foi introduzido por Dozier (1981). Este método, desenvolvido inicialmente para o sensor "Advanced Very High Resolution Radiometer" (AVHRR), explora a diferença existente na resposta dos canais centrados em 4 micrometros $(\mu \mathrm{m})$ e $11 \mu \mathrm{m}$ para as altas temperaturas. Nesse método, o pixel é separado nos componentes fogo e background (porção do pixel em que 
não está ocorrendo a queimada), sendo as Equações 3 e 4 resolvidas em função da temperatura do fogo e do background e da área do subpixel.

$$
\begin{aligned}
& L_{4 \mu m}=A_{f} \cdot B\left(\lambda_{4 \mu m}, T_{f}\right)+\left(1-A_{f}\right) \cdot B\left(\lambda_{4 \mu m}, T_{b}\right) \\
& L_{11 \mu m}=A_{f} \cdot B\left(\lambda_{11 \mu m}, T_{f}\right)+\left(1-A_{f}\right) \cdot B\left(\lambda_{11 \mu m}, T_{b}\right)
\end{aligned}
$$

em que $L$ representa a radiância espectral $\left(\mathrm{W} \cdot \mathrm{m}^{-2} \mathrm{sr}^{-1} \mu \mathrm{m}^{-1}\right)$ nos canais centrados em $4 \mu \mathrm{m}$ e $11 \mu \mathrm{m}$, $B(\lambda, T)$ é a função de Planck, $A_{f}$ é a área do fogo $\left(\mathrm{m}^{2}\right)$, $\lambda$ é o comprimento de onda $(\mu \mathrm{m})$ e $T_{f}$ e $T_{b}$ representam, respectivamente, a temperatura do fogo e do background (K).

De acordo com Eckman et al. (2008), a aplicação do método de Dozier exige algumas suposições: o componente fogo tenha uma única temperatura; o componente background se comporte como um corpo negro e que a interferência da atmosfera seja mínima. Além disso, erros introduzidos no processo de aquisição dos dados como ruídos eletrônicos, erros de registro entre bandas de diferentes resoluções espaciais, saturação e função de espalhamento pontual podem ocasionar variações superiores a 100\% nos valores estimados (Giglio et al., 2003).

Considerando essas limitações, Kaufman et al. (1996) desenvolveram um método que utiliza apenas uma banda espectral para estimar a FRP, sem levar em consideração as componentes $T_{f}$ e $A_{f}$. Nesse método, que é utilizado no produto de fogo ativo derivado do sensor "Moderate Resolution Imaging Spectroradiometer" (MODIS), a FRP é estimada a partir da Equação 5:

$$
F R P=4,3 \cdot 10^{-19} \cdot\left(T_{f 4 \mu m}^{8}-T_{b 4 \mu m}^{8}\right) \cdot A_{\text {real }}
$$

em que FRP é a potência radiativa do fogo (MW ou MJ.s $\left.{ }^{-1}\right), T_{f}$ é a temperatura de brilho do pixel com anomalia térmica em $4 \mu \mathrm{m}(\mathrm{K}), T_{b}$ é a temperatura do background em $4 \mu \mathrm{m}(\mathrm{K})$ e $A_{\text {real }}$ é a área real do pixel $\left(\mathrm{km}^{2}\right)$.

Outro método que permite estimar a FRP a partir de apenas uma banda espectral foi proposto por Wooster et al. (2005). Nesse método, utilizado no produto de fogo ativo derivado do "Spinning Enhanced Visible and Infrared Imager" (SEVIRI), a FRP é estimada empregando a radiância espectral na região do infravermelho médio, como apresentado na Equação 6.

$$
F R P=\frac{A_{\text {pixel }}}{a} \cdot \sigma \cdot \varepsilon \cdot \int_{\lambda \mathrm{f}}^{\lambda \mathrm{i}} B(\lambda, \mathrm{T}) d \lambda-L_{b}
$$

em que $A_{\text {pixel }}$ é o tamanho do pixel $\left(\mathrm{km}^{2}\right)$, a é uma constante de calibração baseada na resposta espectral de cada sensor $\left(\mathrm{W} \cdot \mathrm{m}^{-2} \cdot \mathrm{sr}^{-1} \cdot \mu \mathrm{m}^{-1} \cdot \mathrm{K}^{-4}\right.$ ) extraída de Wooster et al. (2005), $L_{b}$ é a radiância espectral do background, e $\lambda_{i}$ e $\lambda_{f}$ são o comprimento de onda inicial e final correspondentes a largura de banda do sensor $(\mu \mathrm{m})$.

Com o uso dos métodos que utilizam apenas uma banda espectral, algumas pressuposições e limitações impostas pelos métodos bi-espectrais são superadas, como a ausência de erros de registro entre bandas de diferentes resoluções espaciais.

\section{Coeficientes de biomassa queimada}

A partir dos resultados encontrados por Wooster (2002), vários trabalhos foram realizados com o intuito de encontrar o coeficiente de biomassa queimada, que relaciona a FRP e a biomassa queimada. Assim, Wooster et al. (2005), Freeborn et al. (2008) e Pereira et al. (2012) realizaram experimentos de combustão em pequena escala para estimar essa relação a partir da queima

Bol. Ciênc. Geod., sec. Artigos, Curitiba, v. 21, nº 2, p.371-388, abr-jun, 2015. 
controlada de quantidades conhecidas de biomassa. A análise da relação entre a FRP e a taxa de biomassa queimada (TBQ) originou as Equações 7, 8 e 9, respectivamente:

$$
\begin{gathered}
T B Q_{\text {Savana }}=0,368 \cdot F R P \\
T B Q_{\text {Floresta }}=0,453 \cdot F R P \\
T B Q_{\text {Gramineas }}=0,949 . F R P
\end{gathered}
$$

em que $T B Q$ é a taxa de biomassa queimada $\left(\mathrm{kg} . \mathrm{s}^{-1}\right), F R P$ é a potência radiativa do fogo (MW) e o coeficiente multiplicativo está em kg.MJ ${ }^{-1}$.

Cabe ressaltar que as espécies vegetais utilizadas para se chegar às Equações 7, 8 e 9 eram distintas, sendo os coeficientes apresentados acima específicos para espécies vegetais da Savana Africana (Wooster et al., 2005), para espécies vegetais da floresta nativa Norte-americana (Freeborn et al., 2008) e para espécies vegetais do Pantanal e gramíneas (Pereira et al., 2012). Ainda, é importante salientar que para se chegar ao total de biomassa queimada é preciso integrar a $T B Q$ ao longo do tempo de duração da queimada.

\section{Materiais e métodos}

\subsection{Experimento de combustão em pequena escala}

O experimento para analisar a influência do ângulo de visada na FRP a partir da queima de quantidades controladas de biomassa ocorreu nos dias 10/07/2013 e 11/07/2013 no Campus Tancredo Neves da Universidade Federal de São João del Rei (UFSJ), com a colaboração da UFSJ e da EMBRAPA Meio Ambiente. Cabe aqui ressaltar que o tipo de biomassa utilizada durante o experimento de combustão em pequena escala foi a palha da cana-de-açúcar.

Para obter a temperatura durante a combustão das amostras e estimar a FRP, foi utilizado como instrumento uma câmera termal (Figura 1) fabricada pela empresa FLIR Systems Incorporation. $\mathrm{O}$ modelo $\mathrm{A} 310$ possui um frame de 320x240 pixels, chegando à máxima temperatura captada de $1200^{\circ}$ Celsius $\left({ }^{\circ} \mathrm{C}\right)$, sendo a faixa do espectro eletromagnético em que o instrumento opera correspondente à região espectral do infravermelho termal, nos comprimentos de onda entre $7,5 \mu \mathrm{m}$ e $13 \mu \mathrm{m}$. A FLIR A310 opera em 3 faixas de temperatura, entre $-20^{\circ} \mathrm{C}$ e $120^{\circ} \mathrm{C}$, entre $0^{\circ} \mathrm{C}$ e $350^{\circ} \mathrm{C}$ e entre $200^{\circ} \mathrm{C}$ e $1200^{\circ} \mathrm{C}$, sendo que para cada faixa de temperatura existe uma calibração específica. Como a temperatura de uma queimada pode atingir mais de $900^{\circ} \mathrm{C}$, a faixa de temperatura mais adequada para o experimento de combustão em pequena escala é a de $200^{\circ} \mathrm{C} \mathrm{a}$ $1200^{\circ} \mathrm{C}$. Porém, nessa faixa de temperatura as temperaturas menores que $80^{\circ} \mathrm{C}$ não são discretizadas, devido à calibração e otimização do instrumento. 


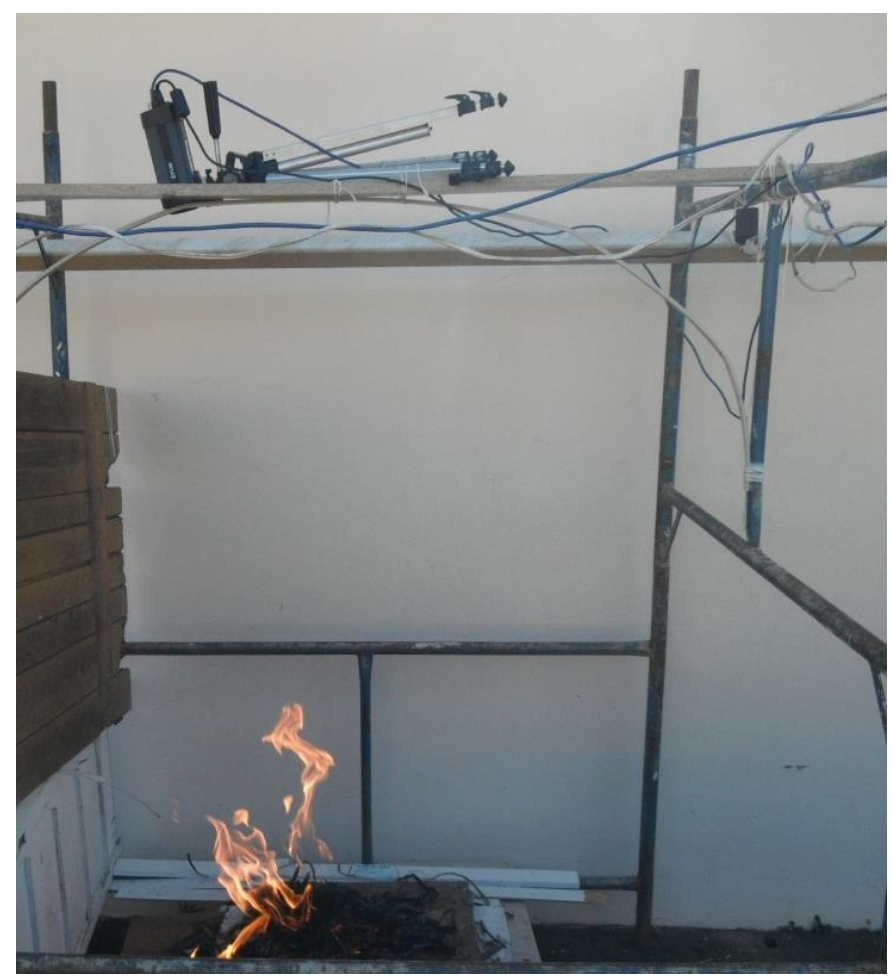

Figura 1: Estrutura utilizada durante o experimento de combustão em pequena escala.

Para calibração da câmera termal, foram adotadas como condições iniciais a faixa de temperatura de $200^{\circ} \mathrm{C}$ a $1200^{\circ} \mathrm{C}$, temperatura atmosférica $19^{\circ} \mathrm{C}$ e umidade do ar $79 \%$, sendo a temperatura atmosférica e a umidade do ar obtidas no início do experimento a partir de uma estação climatológica portátil. Os dados foram adquiridos pela câmera termal com o uso de uma lente de $15^{\circ}$ a uma frequência de $5 \mathrm{Hertz}(\mathrm{Hz})$.

A Tabela 1 apresenta os ângulos de visada, os pesos e o número de amostras analisadas durante o experimento de combustão em pequena escala. Apesar de serem submetidas ao processo de combustão 156 amostras de palha de cana-de-açúcar, algumas foram perdidas ou removidas da análise inicial, como será discutido em seguida, sendo que no total foram analisadas 139 amostras. 
Tabela 1: Peso de cada amostra, número de amostras para cada ângulo de visada e total de amostras utilizadas no experimento de combustão em pequena escala.

\begin{tabular}{c|c|c|c|c|c|c}
\cline { 2 - 6 } & \multicolumn{5}{c|}{ Ângulo de Visada } & \multicolumn{1}{c}{} \\
\hline $\begin{array}{c}\text { Peso da } \\
\text { Amostra (g) }\end{array}$ & $0^{\circ}$ & $10^{\circ}$ & $20^{\circ}$ & $30^{\circ}$ & $40^{\circ}$ & $\begin{array}{c}\text { Total de } \\
\text { Amostras }\end{array}$ \\
\hline 50 & 5 & 5 & 5 & 5 & 6 & 26 \\
\hline 75 & 5 & 5 & 5 & 5 & 6 & 26 \\
\hline 100 & 5 & 5 & 5 & 5 & 6 & 26 \\
\hline 150 & 5 & 5 & 5 & 5 & 6 & 26 \\
\hline 175 & 5 & 5 & 5 & 5 & 6 & 26 \\
\hline 200 & 5 & 5 & 5 & 5 & 6 & 26 \\
\hline
\end{tabular}

Na Tabela 1 é possível verificar o maior número de amostras para o ângulo de visada de $40^{\circ}$, uma vez que essa ótica também foi utilizada para analisar a posição do início da combustão em relação ao sensor na estimativa da FRP. Durante o experimento, o início do processo de combustão sempre se iniciou com as chamas em direção ao sensor (forward), a fim de manter um padrão para as amostras, com exceção das 3 amostras em que o processo de combustão se iniciou com as chamas ao contrário do sensor (backward) para cada peso com ângulo de visada de $40^{\circ}$.

Ainda, evitou-se sempre a influência de alterações das variáveis velocidade do vento, umidade e contaminação por altas temperaturas nas estimativas. Durante as etapas envolvidas, utilizou-se uma estação meteorológica portátil para medir a velocidade do vento no momento da combustão de cada amostra. Apesar do bloqueio com tapumes de madeira para evitar a influência do vento, como se percebe pela Figura 1, algumas amostras foram influenciadas por essa variável, e foram, dessa forma, removidas da análise inicial e analisadas separadamente.

Para algumas amostras, notava-se claramente o teor mais alto de umidade, o que dificultava ou até mesmo impedia o início do processo de combustão. As amostras mais úmidas, assim como as amostras influenciadas pelo vento, também foram removidas da análise inicial e analisadas separadamente. Após o experimento, algumas amostras que estavam mais úmidas foram encaminhadas para análise laboratorial na EMBRAPA Meio Ambiente, a fim de analisar seu teor de umidade, que foi estimado em $18,58 \%$, um valor alto quando comparado com experimentos semelhantes presentes em literatura.

Para evitar a contaminação das amostras pelas altas temperaturas das plataformas que as amparavam, optou-se por fazer um revezamento entre quatro plataformas diferentes para expor as amostras à combustão, assim, enquanto uma plataforma era utilizada as outras três ficavam à espera esfriando, e só eram utilizadas novamente quando sua temperatura estava abaixo da temperatura mínima discretizada pela câmera termal $\left(80^{\circ} \mathrm{C}\right)$, considerando a faixa de temperatura entre $200^{\circ} \mathrm{C}$ e $1200^{\circ} \mathrm{C}$. 


\subsection{Processamento dos dados coletados no experimento de combustão em pequena escala}

Os dados gerados pela câmera termal durante o experimento de combustão em pequena escala foram processados no software MATLAB, tendo como variáveis de saída após o processamento a FRP, a Energia Radiativa do Fogo (FRE, que corresponde à integração temporal da FRP), a área queimada e o tempo de combustão para cada uma das amostras.

A taxa na qual a energia é emitida pelo fogo na forma de radiação, ou FRP, para cada pixel $\left(F R P_{\text {Pixel }}\right)$ em cada um dos frames gerados pela câmera termal foi estimada a partir da Equação 2 considerando a emissividade igual a 1 . Cabe ressaltar que os pixels com temperatura inferior a $80^{\circ} \mathrm{C}$ foram considerados como background e, portanto, não fizeram parte da estimativa da $F R P_{\text {Pixel }}$. Ainda, a área de cada pixel variava de acordo com a plataforma utilizada para expor as amostras à combustão, pois as mesmas apresentavam espessuras diferentes e, consequentemente, estavam a uma altura diferente em relação ao sensor.

Para a estimativa da FRP de cada frame (FRP Pixel $)$ utilizou-se a Equação 10:

$$
F R P_{\text {frame }}=\sum F R P_{\text {pixel }}
$$

em que $F R P_{\text {Frame }}$ representa a potência radiativa do fogo de cada frame $(\mathrm{MW})$ e $F R P_{\text {Pixel }}$ é a potência radiativa do fogo para cada pixel que contém queimada (MW).

Com base nas estimativas de FRP e seus respectivos horários de ocorrência, a FRE de cada amostra foi estimada pela Equação 11:

$$
F R E=\frac{1}{2} \cdot \sum_{i=1}^{n}\left(F R P_{n}+F R P_{n+1}\right) \cdot \Delta t
$$

onde $F R E$ representa energia radiativa de fogo $(\mathrm{MJ})$ para cada amostra, $F R P_{n}(\mathrm{MW})$ é a potência radiativa de fogo no frame n e $F R P_{n+1}$ (MW) é a potência radiativa de fogo no próximo frame, enquanto $\Delta t$ é o intervalo de tempo (s) entre as estimativas.

\section{Resultados e discussão}

A FRP estimada no nadir para uma amostra de 100 gramas é apresentada na Figura 2. Nos primeiros segundos, a FRP é próxima de zero, uma vez que o processo de combustão se inicia com o espalhamento do fogo na amostra, que, quando ocorre, eleva a FRP rapidamente.

Após um período de combustão crescente, a FRP máxima ocorreu aos 56 segundos desde o início do processo de combustão, chegando a valores próximos de 0,028 MW. Em seguida, a FRP diminui, pois a quantidade de biomassa a ser consumida no processo de combustão diminui e inicia-se o estado de brasa (smoldering) em torno de 100 segundos. 


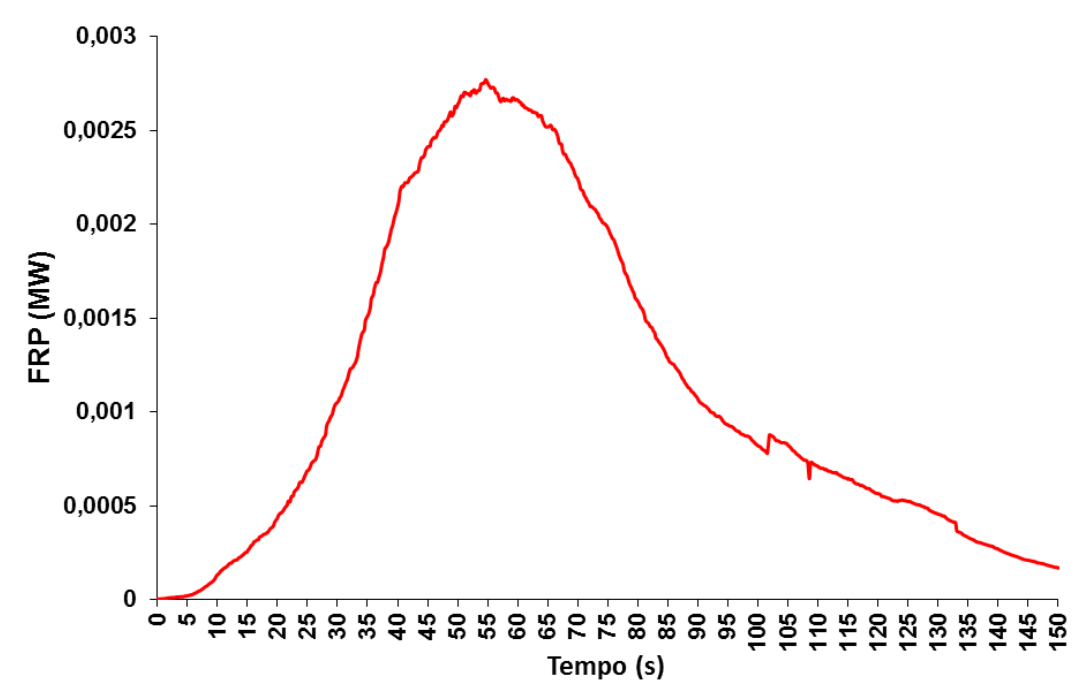

Figura 2: Estimativa da FRP no nadir ao longo do processo de combustão para uma amostra de 100 gramas.

Para Wooster et al. (2005), a fase smoldering pode durar por muito tempo de acordo com o tipo biomassa em combustão, e existe uma tendência a perder-se menos biomassa em relação à FRP liberada porque a FRP depende diretamente da temperatura, e, enquanto a quantidade de biomassa disponível nesta fase é pequena, a temperatura ainda é alta. Desta forma, a fase smoldering foi removida para as demais estimativas de FRP apresentadas nos resultados quando a mesma era evidente.

Para diferentes pesos e um mesmo ângulo de visada, a FRP tende a aumentar de acordo com o aumento da biomassa. A Figura 3 compara a FRP para 5 amostras com diferentes pesos e a câmera termal posicionada no nadir, sendo possível constatar que com o aumento da quantidade de biomassa disponível para queima a FRP máxima é maior.

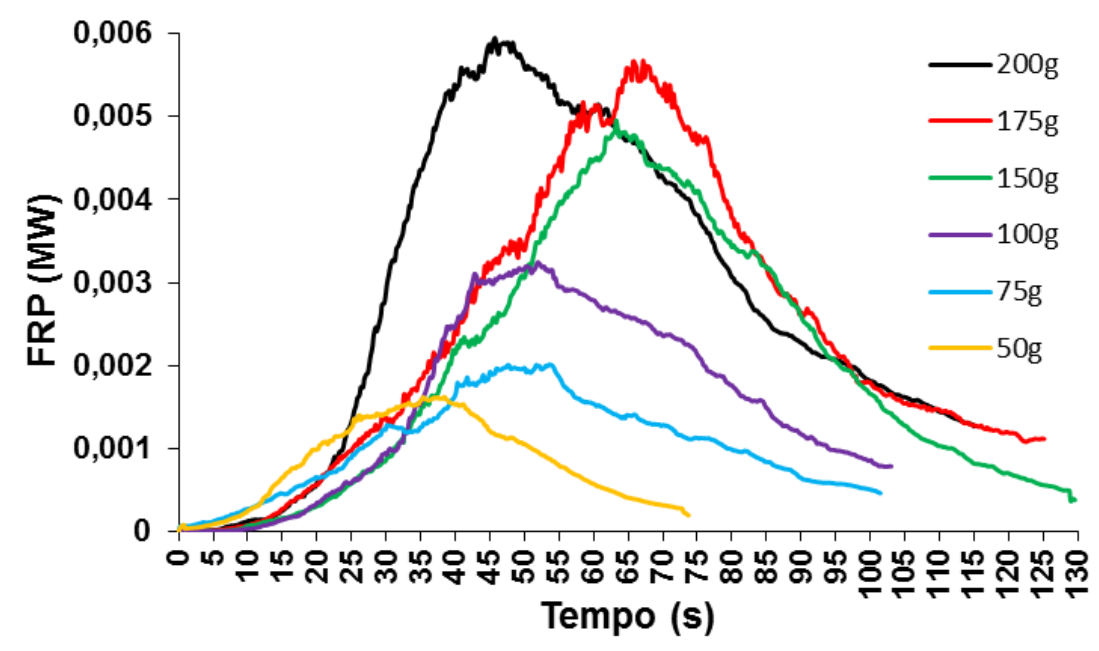

Figura 3: Estimativas da FRP estimada no nadir para amostras de diferentes pesos.

Nota-se ainda que para a amostra de 200 gramas a FRP é elevada rapidamente no início da combustão e entra em fase smoldering antes das amostras de 175 gramas e 150 gramas, o que 
pode ter ocorrido devido ao menor teor de umidade da amostra de 200 gramas, que encontravase mais seca do que as demais amostras. Ainda em relação aos resultados apresentados na Figura 3, como a FRE é a integração temporal da FRP, mesmo que a amostra de 200 gramas entre na fase smoldering em menos tempo isso não significa que a FRE será menor em comparação às demais amostras, pois a FRP dessa amostra foi maior do que a FRP das outras amostras no tempo em que estava na fase chamas. As estimativas de FRE das amostras apresentadas na Figura 3 estão presentes na Figura 4.

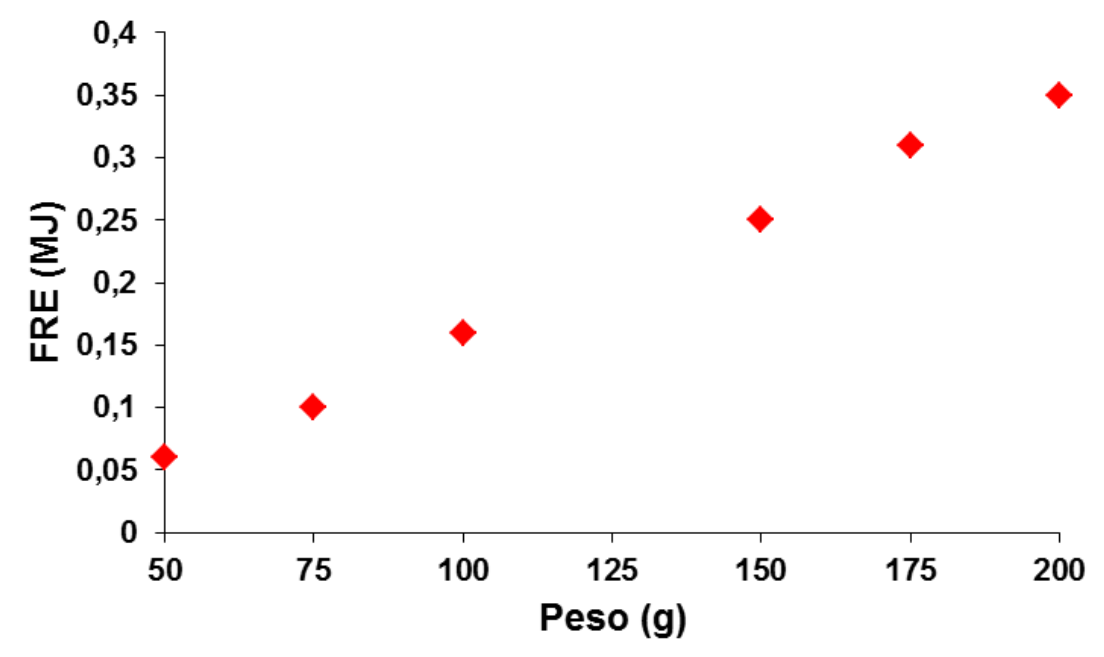

Figura 4: Estimativa da FRE para as amostras apresentadas na Figura.

A influência do vento na estimativa da FRP é analisada a partir da Figura 5. Nesta figura, são apresentadas as estimativas da FRP para duas amostras de 175 gramas com ângulo de visada de $30^{\circ}$, sendo que em uma das amostras a velocidade do vento medida pela estação meteorológica portátil foi $0 \mathrm{~km} / \mathrm{h}$ e na outra amostra a velocidade do vento chegou a $3 \mathrm{~km} / \mathrm{h}$.

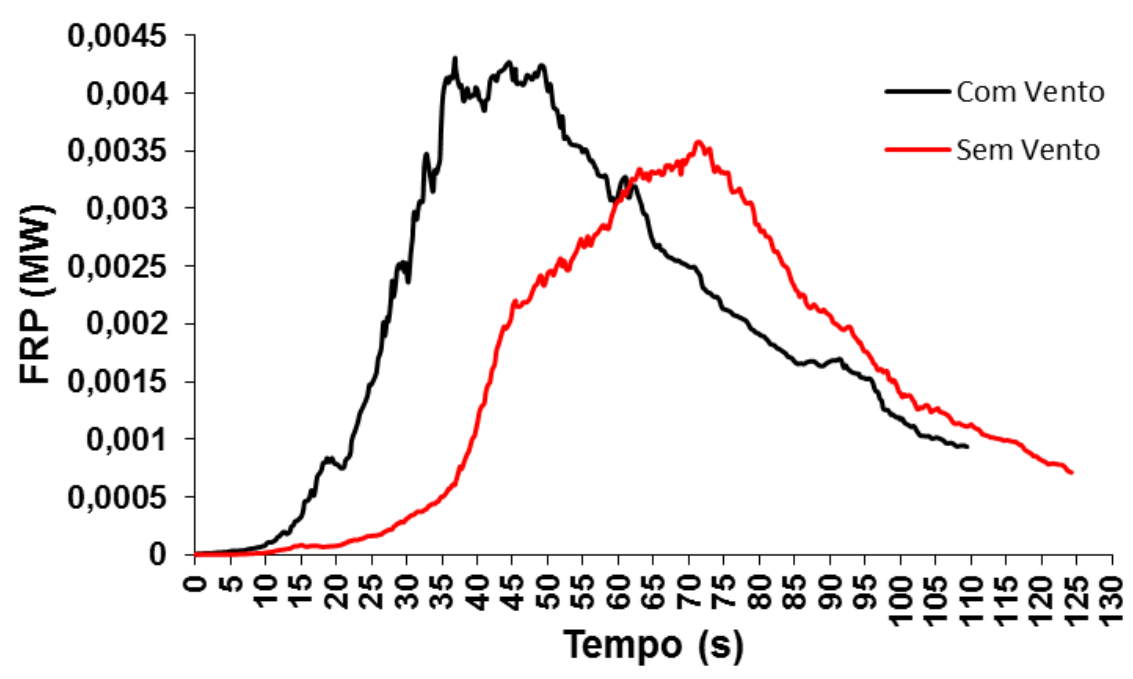

Figura 5: Estimativa da FRP durante o processo de combustão para duas amostras de 175 gramas, uma com influência do vento e outra amostra sem vento. 
Para a amostra com vento, observa-se a influência da velocidade do vento em torno de 7 segundos, o que ocasiona o espalhamento do fogo mais rapidamente, e eleva a FRP nos segundos iniciais da combustão, chegando a atingir 0,0042 MW aos 38 segundos, e o início da fase smoldering inicia-se em aproximadamente 107 segundos. Na amostra sem vento, percebe-se que o espalhamento do fogo pela amostra foi mais demorado, com início em cerca de 15 segundos e espalhamento efetivo por toda a amostra a partir de 38 segundos, aproximadamente o mesmo tempo em que a emissão de FRP da amostra com vento era máxima, sendo que a FRP máxima da amostra sem vento foi de 0,0035 MW, e o início da fase smoldering mais tardiamente, a partir de 124 segundos. Em relação à FRE, a amostra com vento foi $7 \%$ maior do que a média das amostras de 175 gramas com ângulo de visada de $30^{\circ}$.

A comparação da FRP estimada no nadir para duas amostras de 150 gramas de palha de canade-açúcar, uma seca e uma úmida, é apresentada na Figura 6.

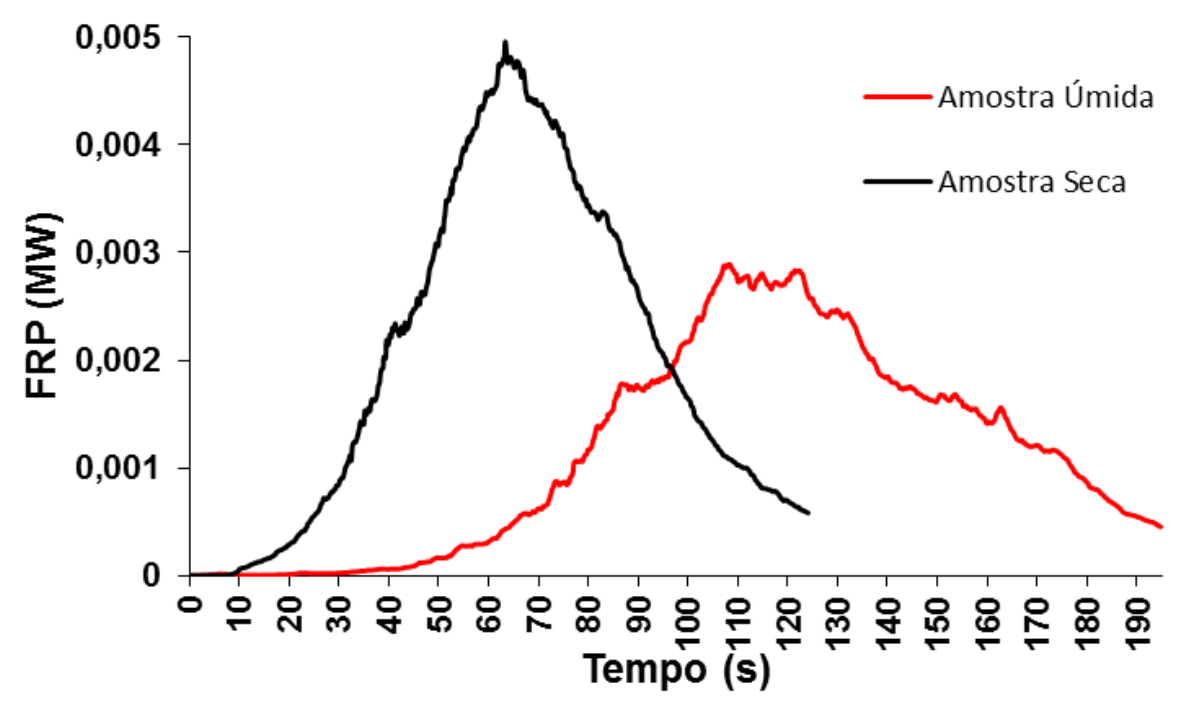

Figura 6: Estimativa da FRP no nadir para duas amostras de 150 gramas, sendo uma amostra seca e uma amostra úmida.

Em um primeiro momento, o que se destaca na Figura 6 é o tempo transcorrido na amostra úmida até chegar à fase smoldering, enquanto que a amostra seca entra em estado de brasa 120 segundos depois do início da combustão, a amostra úmida, de mesmo peso, demorou mais de 195 segundos para entrar em estado de brasa. Em relação ao espalhamento do fogo pela amostra, na amostra seca ele acontece em torno de 20 segundos, com a elevação rápida da FRP, que chega a atingir 0,005 MW. Para a amostra úmida, o espalhamento do fogo demora a ocorrer, e começa a elevar a FRP somente após 32 segundos depois do início do processo de combustão, com FRP máxima correspondente a 0,0028 MW em 110 segundos, pois a presença de umidade na vegetação influencia diretamente na redução da FRP, situação também encontrada por Riggan et al. (2004).

Em relação à FRE, a amostra úmida foi $7 \%$ menor do que a FRE média estimada para as amostras de 150 gramas no nadir, o que pode ser explicado pelo fato da temperatura da amostra úmida ser menor ao longo do processo de combustão, e a FRP, que origina a FRE, ser dependente da temperatura elevada à quarta potência.

Para a análise da posição da chama em relação ao sensor na estimativa da FRP, essa variável foi estimada para um mesmo peso com as chamas em direção ao sensor (forward) e com as chamas 
opostas à posição do sensor (backward) na visada de $40^{\circ}$. A Figura 7 compara duas amostras de 200 gramas para as situações descritas acima.

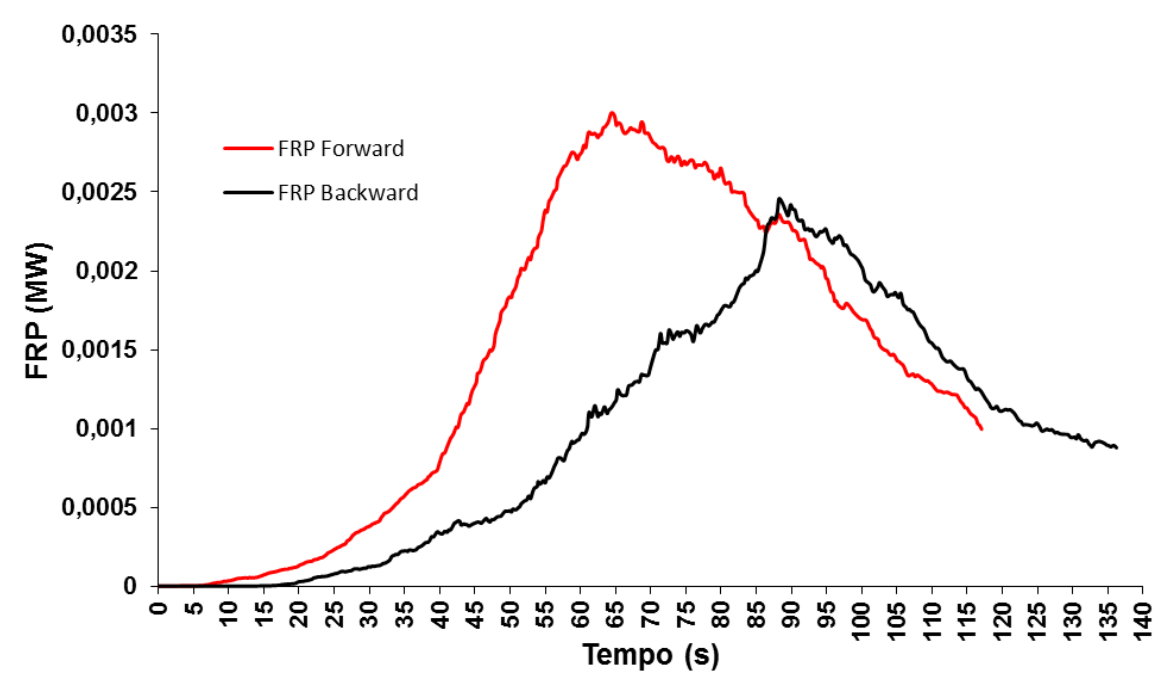

Figura 7: Estimativa da FRP com ângulo de visada de $40^{\circ}$ para duas amostras, uma amostra na posição forward e a outra amostra na posição backward.

Nota-se que a FRP backward é menor em relação à FRP forward, sendo a FRP máxima emitida para a amostra na posição forward quase $20 \%$ maior que aquela na posição backward no momento da máxima emissão. Esse resultado pode ter sido causado pela fumaça resultante da queima, que na posição backward ficava entre a câmera termal e as amostras durante o processo de combustão, portanto a temperatura estimada pode não ser representativa do fogo, e sim uma mistura entre a chama e a fumaça. Para a análise da posição do sensor em relação à estimativa da FRP, o ideal seria utilizar dois sensores no experimento de combustão em pequena escala, pois essa metodologia isto permitiria uma comparação mais profunda das estimativas para uma mesma amostra.

Para o ângulo da visada, notou-se que para uma mesma quantidade de biomassa a FRP diminui de acordo com o aumento do ângulo. A Figura 8 compara a FRP de 5 amostras de 100 gramas, uma de cada ângulo de visada analisado.

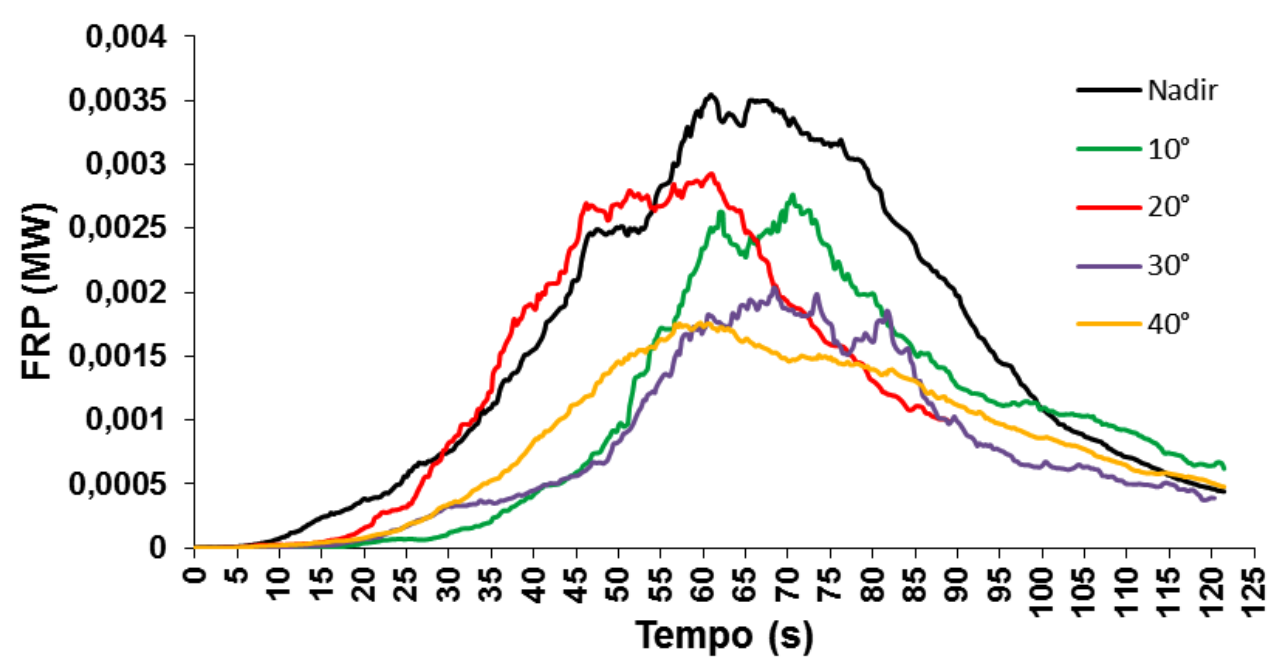

Figura 8: Estimativas da FRP para amostras de 100 gramas com diferentes ângulos de visada. 
Ao comparar a FRP máxima emitida para as amostras presentes na Figura 8 percebe-se que no nadir ela é praticamente o dobro da FRP máxima emitida para 40 graus, pois, em média, menos energia é detectada por unidade de biomassa queimada conforme o ângulo de visada se torna mais oblíquo (Freeborn et al. 2008). No nadir, a temperatura de um pixel com queimada seria maior do que a temperatura do mesmo pixel em um ângulo de visada mais oblíquo, já que o fogo é visto na vertical e, portanto, é mais intenso. Resultado semelhante foi encontrado por Freeborn et al. (2008), que estimaram a FRP e a área queimada de 21 amostras com dois sensores, um posicionado sempre no nadir e o outro fora do nadir, e chegaram à conclusão de que o campo de visada instantâneo (IFOV) do sensor influencia a estimativa da temperatura, uma vez que a distribuição da temperatura no subpixel será afetada.

Para a área em processo de combustão, nota-se que a área queimada no nadir também é maior, como demonstra a Figura 9, que compara a área queimada para as mesmas amostras presentes na Figura 8.

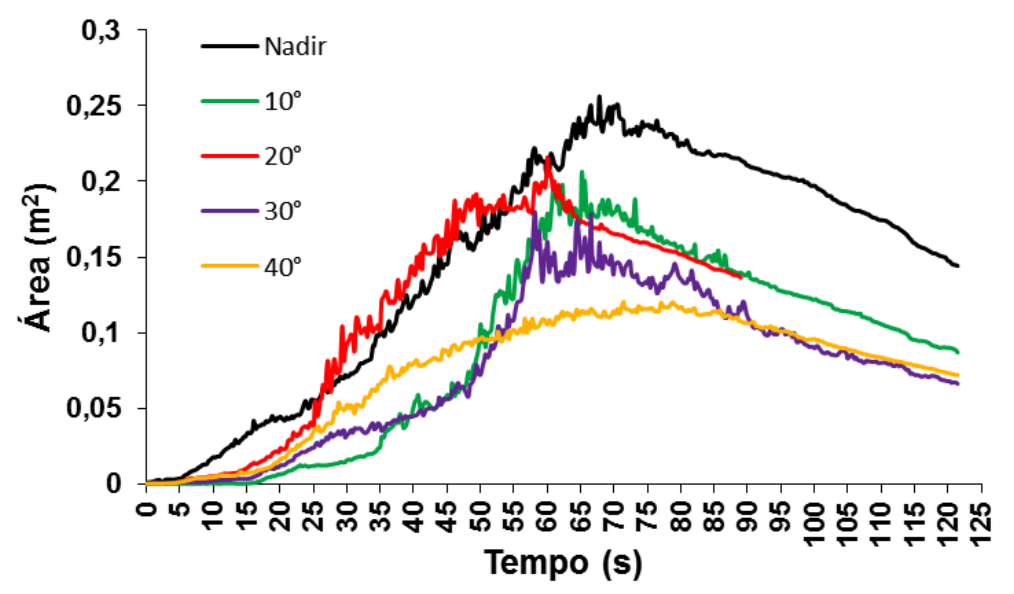

Figura 9: Área queimada para as amostras apresentadas na Figura 8.

Mantendo-se a área imageada, e a mesma sendo visualizada com ângulos diferentes, a área queimada será menor conforme o aumento do ângulo de visada, uma vez que a projeção do detector sobre a área em que está ocorrendo a queimada é maior. Contudo, em alguns casos a área queimada para uma mesma quantidade de biomassa foi maior em um ângulo mais oblíquo, como demonstrado na Figura 10.

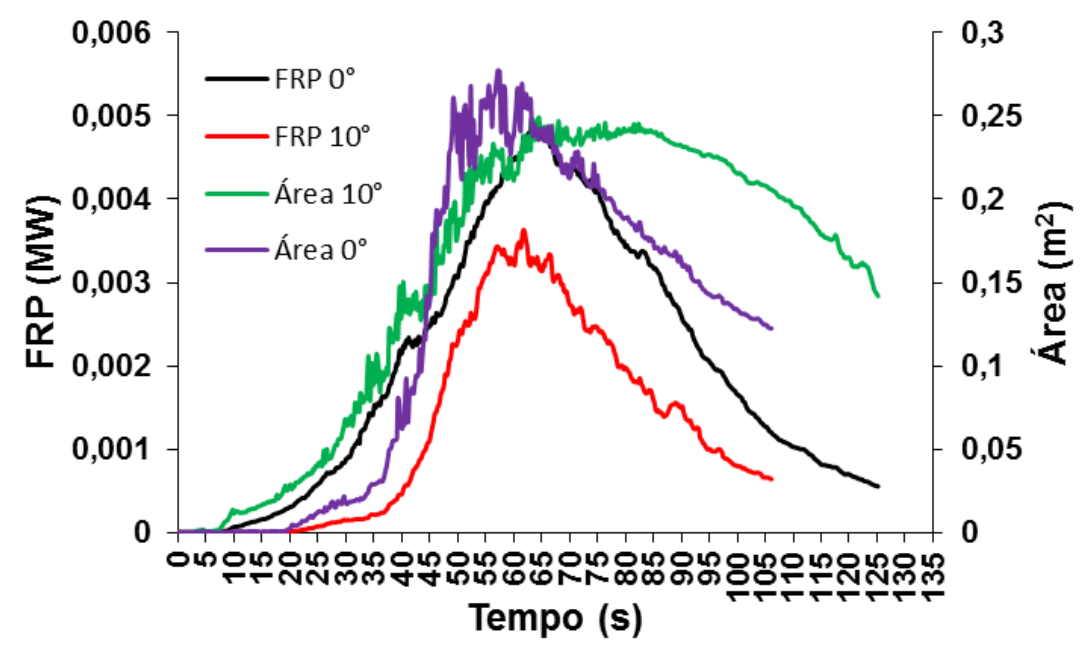

Figura 10: Estimativas da FRP e da área queimada para duas amostras, uma no nadir e outra com ângulo de visada de $10^{\circ}$. 
Uma possível explicação para o ocorrido é o fato das chamas na amostra coletada com visada de 10 graus estarem altas, portanto essa chama pode ter sido projetada em uma área que não estava queimando, como ocorreu no experimento realizado por Paugam et al. (2013). Segundo Freeborn et al. (2008), o aumento do ângulo de visada pode causar a projeção das chamas sobre áreas em que não estava ocorrendo a queimada, o que geralmente ocorre com maiores quantidades de biomassa. Ainda assim, percebe-se que a FRP no nadir é maior, já que nessa geometria de aquisição a temperatura é mais intensa por estar sendo vista na vertical, como discutido anteriormente.

Como discutido anteriormente para as estimativas da FRP forward e backward, para uma comparação mais profunda entre a FRP e a área queimada com diferentes ângulos de visada o ideal seria analisar uma amostra com mais de um sensor, pois vários fatores interferem na estimativa da FRP, e mesmo com a tentativa de controlar esses fatores dificilmente duas amostras apresentarão a mesma FRP ao longo do processo de combustão.

A diminuição das estimativas de acordo com o aumento do ângulo se reflete na FRE, pois os valores tendem a cair linearmente de acordo com o aumento do ângulo de visada, como no exemplo apresentado na Figura 11, que compara as estimativas da FRE média para as amostras de 150 gramas nos diferentes ângulos de visada analisados.

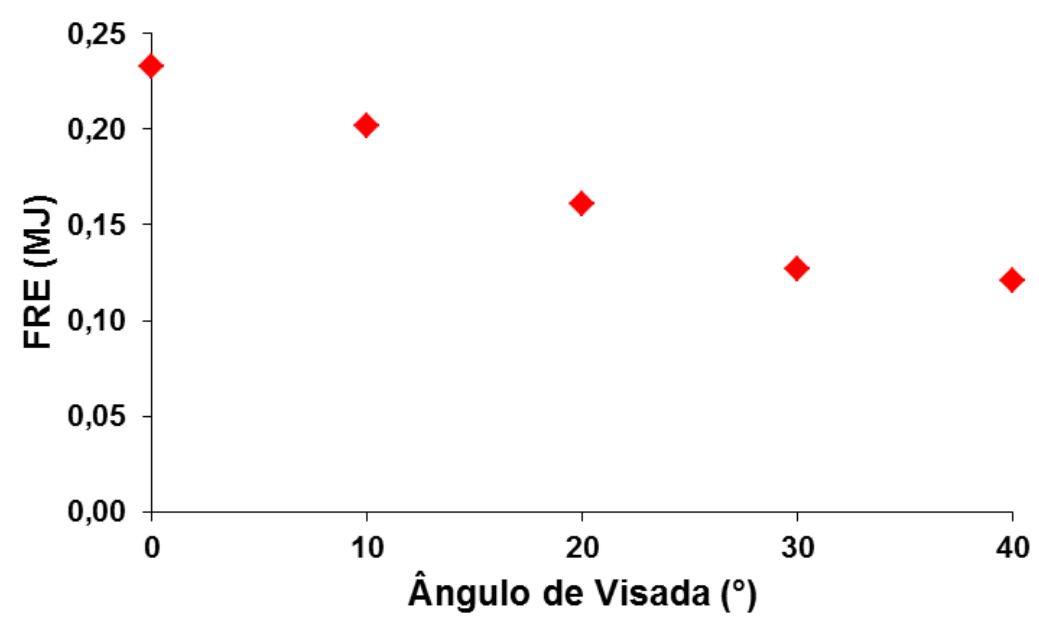

Figura 11: FRE média para as amostras de 150 gramas com diferentes ângulos de visada.

Com isso, a determinação do coeficiente de biomassa queimada para a cana-de-açúcar também considerou o ângulo de visada. O coeficiente apresentado na Equação 12 foi submetido ao teste estatístico t-Student e considerado significativo a $5 \%$.

$$
T B Q_{\text {Cana }}=(2,44 \cdot F R P)-(1,87 \cdot \cos \theta \cdot F R P)
$$

em que $T B Q_{\text {Cana }}$ é a taxa de biomassa queimada para a cana-de-açúcar $\left(\mathrm{kg} . \mathrm{s}^{-1}\right), F R P$ é a potência radiativa do fogo (MW) e $\theta$ é o ângulo de visada do sensor no momento da aquisição dos dados.

Deve-se ressaltar que para se chegar à Equação 12, multiplicou-se a biomassa de cada amostra pelo fator de combustão da palha da cana-de-açúcar, uma vez que a palha da cana-de-açúcar não é totalmente consumida pela combustão. O fator de combustão utilizado, ou seja, a fração de biomassa que é realmente queimada, foi 0,9, determinado por França et al. (2012) a partir de um 
experimento de combustão em pequena escala realizado para determinar os fatores de emissão da cana-de-açúcar.

Analisando os coeficientes de biomassa queimada encontrados em literatura, a taxa de biomassa queimada é invariável de acordo com a variação do ângulo de visada, o que não corresponde à realidade, visto que, como mostrado anteriormente, a FRP tende a diminuir de acordo com o aumento do ângulo de visada. O coeficiente de biomassa queimada encontrado tem por objetivo corrigir a influência do ângulo na estimativa da FRP, já que essa diminuição da FRP causa pelo ângulo é considerada. No entanto, é necessário avaliá-lo com dados coletados em condições reais de queima a fim de testar sua real efetividade.

\section{Conclusões}

Os resultados encontrados no experimento de combustão em pequena escala permitiram determinar relação entre o ângulo de visada e a estimativa da FRP. Para o ângulo de visada, as estimativas da FRP diminuíram de acordo com o seu aumento, com as estimativas da FRP no nadir podendo chegar a atingir o dobro das estimativas com ângulo de visada de $40^{\circ}$ para uma mesma quantidade de biomassa.

Como sugestão para trabalhos futuros, deve-se analisar a queima de uma amostra de biomassa com dois sensores posicionados com ângulos diferentes, pois a FRP pode variar muito de acordo com fatores como o ângulo de visada, o teor de umidade da amostra, o vento e a posição da queimada em relação ao sensor, portanto, dificilmente duas amostras de mesma biomassa e mesmo peso apresentarão FRP idêntica ao longo do processo de combustão.

Sempre que possível é indicado o controle dos fatores apresentados acima, principalmente o teor de umidade das amostras, sendo o ideal que todas apresentem o mesmo teor de umidade.

Ainda, para avaliar a efetividade do coeficiente de biomassa encontrado deve-se aplicá-lo a experimentos em campo, ou seja, estimar a FRP e a biomassa queimada a partir da queima de talhões de cana-de-açúcar em condições reais.

Por fim, espera-se no futuro empregar a metodologia que utiliza a FRP para estimar a quantidade de biomassa queimada e as emissões de gases do efeito estufa provenientes da queimada précolheita da cana-de-açúcar para a região Centro-Sul do Brasil.

\section{AGRADECIMENTOS}

À Coordenação de Aperfeiçoamento de Pessoal de Nível Superior (Capes) pela concessão da bolsa de mestrado e à UFSJ e EMBRAPA Meio Ambiente pela colaboração durante o experimento. 


\section{REFERÊNCIAS BIBLIOGRÁFICAS}

Andreae, M. A., e Merlet, P. "Emission of trace gases and aerosols from biomass burning." Global Biogeochemical Cycles 4 (2009): 955-966. Acesso em 07 Outubro, 2014. doi: 2000GB001382. 0886-6236/01/2000GB001382\$12.00.

Dozier, J. "A method for satellite identification of surface temperature fields of subpixel resolution." Remote Sensing of Environment 11(1981): 221-229. Acesso em 03 Outubro, 2014. doi: 0034-4257/81/030221 + 9502 50 .

Eckman, Ted C., Roberts, Dar A., e Still, Christopher J. "Using multiple endmember spectral mixture analysis to retrieve subpixel fire properties from MODIS." Remote Sensing of Environment 112 (2008): 3773-3783. Acesso em 29 Setembro, 2014. doi: 10.1016/j.rse.2008.05.008.

Eckman, Ted C, Still, Christopher J, Roberts, Dar A., e Michaelsen, Joel C. "Variations in subpixel fire properties with season and land cover in Southern Africa." Earth Interactions 4 (2010): 1-29. Acesso em 03 Outubro, 2014. doi: 10.1175/2010EI328.1.

França, Daniela de Azevedo, Longo, Karla Maria, Soares Neto, Turibio Gomes, Santos, José Carlos, Freitas, Saulo Ribeiro, Rudorff, Bernardo F. T., Cortez, Ely Vieira, Anselmo, Edson e Carvalho Junior, João Andrade. "Pre-harvest sugarcane burning: determination of emission factors through laboratory measurements." Atmosphere 3 (2012): 164-180. Acesso em 08 Outubro, 2014. doi: 10.3390/atmos3010164.

Freeborn, Patrick H., Wooster, Martin J., Hao, Wei Min, Ryan, Cecily, A., Nordgren, Bryce L., Baker, Stephen P., e Ichoku, Charles. "Relationships between energy release, fuel mass loss, and trace gas and aerosol emissions during laboratory biomass fires." Journal of Geophysical Research 113 (2008): 1-17. Acesso em 05 Outubro, 2014. doi: 10.1029/2007JD008679.

Freitas, S. R., Longo, K. M., Silva Dias, M. A. F., Chatfield, R., Silva Dias, P., Artaxo, P., Andreae, M. O., Grell, G., Rodrigues, L. F., Fazenda, A., e Panetta, J. "The Coupled Aerosol and Tracer Transport model to the Brazilian developments on the Regional Atmospheric Modeling System (CATT-BRAMS). Part 1: Model description and evaluation." Atmospheric Chemistry and Physics Discussion 7 (2007): 2843-2861. Acesso em 06 Outubro, 2014. doi: 10.5194/acp-92843-2009.

Giglio, L., Kendall, J., e Mack, R. "A multi-year active fire dataset for the tropics derived from the TRMM VIRS." International Journal of Remote Sensing 24 (2003): 4505-4525. Acesso em 03 Outubro, 2014. doi: 10.1080/014311603100007028.

Giglio, L., van der Werf, G. R., Randerson, J. T., Collatz, G. J., e Kasibhatla, P. "Global estimation of burned area using MODIS active fire observations." Atmospheric Chemistry and Physics 6 (2006): 957-974. Acesso em 01 Outubro, 2014. doi: 10.5194/acp-6-957-2006.

Hantson, Stijn, Padilla, Marc, Corti, Dante, e Chuvieco, Emilio. "Strengths and weaknesses of MODIS hotspots to characterize global fire occurrence." Remote Sensing of Environment 131 (2013): 152-159. Acesso em 03 Outubro, 2014. doi: 10.1016/j.rse.2012.12.004.

Ichoku,Charles, Giglio, Louis, Wooster, Martin J., e Remer, Lorraine R. "Global characterization of biomass burning patterns using satellite measurements of fire radiative energy." Remote Sensing of Environment 112 (2008): 2950-2962. Acesso em 04 Outubro, 2014. doi: 10.1016/j.rse.2008.02.009.

Ichoku, Charles, Kahn, Ralph, e Chin, Mian. "Satellite contributions to the quantitative characterization of biomass burning for climate modeling." Atmospheric Research 111 (2012): 1-28. Acesso em 10 Outubro, 2014. doi: 10.1016/j.atmosres.2012.03.007. 
Kaufman, Yoran J., Remer, Lorraine A., Ottmar, Roger D., Ward, Darold E., Li, Rong R., Kleidman, Richard, Fraser, Robert S., Flynn, Luke, McDougal, David, e Shelton, Gary. "Relationship between remotely sensed fire intensity and rate of emission of smoke: SCAR-C experiment" in Global biomass burning, ed. Joel S. Levine, 685-696. Maryland: MIT Press, 1996.

Lauk, Christian, e Erb, Karl-Heinz. “. Biomass consumed in anthropogenic vegetation fires: Global patterns and processes." Ecological Economics 69 (2009): 301-309. Acesso em 06 Outubro, 2014. doi: 10.1016/j.ecolecon.2009.07.003.

Paugam, Ronan, Wooster, Martin J., e Roberts, Gareth. "Use of thermal image data for airbornemapping of fire radiative power and energy and flame front rate of spread." IEEE Transactions on Geoscience and Remote Sensing 51 (2013): 3385-3390. Acesso em 04 Outubro, 2014. doi: 10.1109/TGRS.2012.2220368.

Pereira, Gabriel, Cardozo, Francielle da Silva, Moraes, Elisabete Caria, Ferreira, Nelson Jesus, Freitas, Saulo Ribeiro, Shimabukuro, Yosio Edemir, Breuning, Fábio Marcelo, e Viana, Denilson Ribeiro. "Determinação e modelagem da taxa de consumo de biomassa queimada." Revista Brasileira de Meteorologia 27 (2012): 13-22. Acesso em 08 Outubro, 2014.

Riggan, Philip J., Tissell, Robert G., Lockwood, Robert N., Brass, James A., e Pereira, João Antônio Raposo, Miranda, Heloisa S., Miranda, Antônio C., Campos, Tereza, Higgins, Robert. "Remote measurement of energy and carbon flux from wild-fires in Brazil." Ecological Application 03 (2004): 855-872. Acesso em 08 Outubro, 2014. doi: 10.1890/02-5162.

Roberts, G., Wooster, M. J., Perry, G. L.W., Drake, N., Rebelo, L. M., e Disposito, F. "Retrieval of biomass combustion rates and totals from fire radiative power observations: Application to southern Africa using geostationary SEVIRI imagery." Geophysical Research 110 (2005): 1-20. Acesso em 09 Outubro, 2014. doi: 10.1029/2005JD006018.

Schroeder, Wilfrid, Ellicott, Evan, Ichoku, Charles, Ellison, Luke, Dickinson, Matthew B., Ottmar, Roger D., Clements, Craig, Hall, Dianne, Ambrosia, Vincent, e Kremens, Robert. "Integrated active fire retrievals and biomass burning emissions using complementary near coincident ground, airborne and spaceborne sensor data." Remote Sensing of Environment 140 (2014): 719-730. Acesso em 05 Outubro, 2014. doi: 10.1002/2014JD021993.

Seiler, Wolfgang, e Cutzen, Paul J. "Estimates of gross and net fluxes of carbon between the biosphere and the atmosphere from biomass burning." Climate Change 02 (1980): 207-248. Acesso em 30 Setembro, 2014. doi: 10.1007\%2FBF00137988.

Van der Werf, G. R., Randerson, J. T., Giglio, L., Collatz, G. J., Kasibhatla, P. S., e Arellano Junior, A. F. "Interannual variability in global biomass burning emissions from 1997 to 2004." Atmospheric Chemistry and Physics 06 (2006):3423-3441. Acesso em 01 Outubro, 2014. doi: 10.5194/acp-6-3423-2006.

Vermote, Eric, Ellicott, Evan, Dubovik, Oleg, Lapyonok, Tatyana, Chin, Mian, Giglio, Louis, Roberts, e Gareth J. "An approach to estimate global biomass burning emissions of organic and black carbon from MODIS fire radiative power." Journal of Geophysical Research 114 (2009): 1984-2012. Acesso em 09 Outubro, 2014. doi: 10.1029/2008JD011188.

Wooster, Martin J. "Small-scale experimental testing of fire radiative energy for quantifying mass combusted in natural vegetation fires." Geophysical Research Letters 29 (2002): 231-234. Acesso em 09 Outubro, 2014. doi: 10.1029/2002GL015487.

Wooster, M. J., Zhukov, B., e Oertel, D. "Fire radiative energy for quantitative study of biomass burning: derivation from the BIRD experimental satellite and comparison to MODIS fire products." Remote Sensing of Environment 86 (2003): 83-107. Acesso em 03 Outubro, 2014. doi; 10.1016/S0034-4257(03)00070-1. 
Wooster, M. J. Roberts, G., Perry, G. L. W., e Kaufman, Y. J. “. Retrieval of biomass combustion rates and totals from fire radiative power observations: calibration relationships between biomass consumption and fire radiative energy release." Journal of Geophysical Research 110 (2005): 83-107. Acesso em 03 Outubro, 2014. doi: 10.1029/2005JD006318.

Wooster, M. J., Freeborn, P. H., Archibald, S., Oppenheimer, C., Roberts, G. J., Smith, T. E. L., Govender, N., Burton, M., e Palumbo, I. “. Field determination of Biomass burning emission ratios and factors via open-path FTIR spectroscopy and fire radiative power assessment: head fire, backfire and residual smoldering combustion in African savannahs." Atmospheric Chemistry and Physics 11 (2011): 11591-11615. Acesso em 04 Outubro, 2014. doi: 10.5194/acp-11-115912011.

Xu, W., Wooster, M. J., Roberts, G., e Freeborn, P. "New GOES imager algorithms for cloud and active fire detection and fire radiative power assessment across North, South and Central America" Remote Sensing of Environment 114 (2010): 1876-1895.Acesso em 06 Outubro, 2014. doi: 10.1016/j.rse.2010.03.012.

Recebido em Dezembro de 2014. Aceito em Março de 2015. 


\title{
A MODEL OF FUZZY TOPOLOGICAL RELATIONS FOR SIMPLE SPATIAL OBJECTS IN GIS
}

\author{
Um modelo de relações topológicas fuzzy para objetos espaciais em GIS
}

\author{
BO LIU1,2,3 \\ DAJUN LI \\ JIAN RUAN 2 \\ LIBO ZHANG ${ }^{4}$ \\ LAN YOU $5,1^{*}$ \\ HUAYI WU1
}

\author{
${ }^{1}$ State Key Laboratory of Information Engineering in Surveying, Mapping and Remote Sensing, Wuhan \\ University, 129 Luoyu Road, Wuhan 430079, China \\ ${ }^{2}$ Faculty of Geomatics, East China Institute of Technology, 418\#Guanglan Road, Nanchang 330013, PR, \\ China \\ ${ }^{3}$ Key laboratory of watershed ecology and geographical environment monitoring, National \\ Administration of Surveying, Mapping and Geoinformation, 418\#Guanglan Road, Nanchang 330013, PR, \\ China \\ ${ }^{4}$ National Quality Inspection and Testing Center for Surveying and Mapping Products, 28Lianhuachi West \\ Road, Hai dian District, Beijing 100830, PR, China \\ ${ }^{5}$ Faculty of Computer Science and Information Engineering, Hubei University, \\ 368Youyi Avenue, Wuhan 430062, PR, China
}

bliu@whu.edu.cn; djli@ecit.cn; jruan@ecit.cn; 37856062@qq.com; youlan1025@gmail.com;wuhuayi@whu.edu.cn

\begin{abstract}
:
The goal of this paper is to present a new model of fuzzy topological relations for simple spatial objects in Geographic Information Sciences (GIS). The concept of computational fuzzy topological space is applied to simple fuzzy objects to efficiently and more accurately solve fuzzy topological relations, extending and improving upon previous research in this area. Firstly, we propose a new definition for simple fuzzy line segments and simple fuzzy regions based on computational fuzzy topology. And then, we also propose a new model to compute fuzzy topological relations between simple spatial objects, an analysis of the new model exposes:(1) the topological relations of two simple crisp objects; (2) the topological relations between one simple crisp object and one simple fuzzy object; (3) the topological relations between two simple fuzzy objects. In the end, we have discussed some examples to demonstrate the validity of the new model, through an experiment and comparisons of existing models, we showed that the proposed method can make finer distinctions, as it is more expressive than the existing fuzzy models.


Keyword : Topological Relation; Simple Spatial Objects; Fuzzy Topology; Model; GIS.

\section{Resumo:}

O objetivo deste artigo é apresentar um novo modelo de relações topológicas fuzzy para objetos espaciais simples em Sistemas de Informações Geográficas (SIG). Aplica-se o conceito de espaço topológico fuzzy a objetos fuzzy simples para resolver as relações topológicas de modo mais eficiente e acurado. Inicialmente é proposta uma nova definição para segmentos de linha fuzzy e para regiões fuzzy com base na topologia computacional. Em seguida propõe-se um novo modelo para calcular as relações topológicas fuzzy entre os objetos espaciais. A análise do novo modelo aponta: (1) relações topológicas de dois objetos "crisp"; (2) relações topológicas entre um objeto "crisp" e um objeto fuzzy; (3) relações topológicas entre dois objetos "crisp". Finalmente, discutem-se alguns exemplos para demonstrar a validade do modelo, por meio de um experimento e comparações entre modelos existentes. É possível demonstrar que o método proposto pode realizar distinções mais precisas e á mais expressivo do que os modelos fuzzy existentes.

Palavras-chave : Relações Topológicas; Objetos Espaciais Simples; Topologia Fuzzy; Modelo; GIS.

\section{INTRODUCTION}

Geographical information sciences (GIS) commonly deal with geographical phenomena modeled by crisp points, lines, and regions, features which are clearly defined or have crisp boundaries. However, geospatial data are always uncertain or fuzzy due to inaccurate data acquisition, incomplete representation, dynamic change, and the inherent fuzziness of geographical phenomena itself. In GIS, many studies have been devoted to modeling topological relations, specifically the modeling of fuzzy topological relations between simple spatial objects. Topology is a fundamental challenge when modeling the spatial relations in geospatial data that includes a mix of crisp, fuzzy and complex objects. Two mechanisms, the formalization and reasoning of topological relations, have become popular in recent years to gain knowledge about the relations between these objects at the conceptual and geometrical levels. These mechanisms have been widely used in spatial data query (Egenhofer, 1997, Clementini et al., 1994), spatial data mining (Clementini et al., 2000), evaluation of equivalence and similarity in a spatial scene (Paiva, 1998), and for consistency assessment of the topological relations of multi-resolution spatial databases (Egenhofer et al., 1994, 1995; Du et al., 2008a, b). Diloet al. (2007) defined several types and operators for modeling spatial data systems to handle fuzzy information. Shi et al. (2010) and Liu et al. (2011) developed a new object extraction and classification method based on fuzzy topology. However, the fuzzy topological relationships themselves must be modeled due to the existence of indeterminate and fuzzy boundaries between spatial objects in GIS. Fuzzy topology theory can potentially be applied to the modeling of fuzzy topological relations among spatial objects.

To date, many models have been designed to formalize fuzzy topological relations between simple spatial objects these models provide a framework to conceptually describe the topological relations between two regions and can be considered as an extension of the crisp case. They can be implemented on spatial databases at less cost than other uncertainty models and are useful when managing, storing, querying, and analyzing uncertain data. For example, Egenhofer and Franzosa Bol. Ciênc. Geod., sec. Artigos, Curitiba, v. 21, no 2, p.389-408, abr-jun, 2015. 
(1991a, 1994, 1995) and Winter (2000) modeled the topological relations between two spatial regions in two dimensional space (2-D) based on the 4-intersection model and ordinary point set theory. Li et al. (1999), Long and Li (2013) produced a Voronoi-based 9-intersection model based on Voronoi diagrams. Cohn et al. $(1996,1997)$ discovered forty-six topological relations between two regions with indeterminate boundaries based on Region Connection Calculus (RCC) theory (Randell et al., 1992). Clementini and Di Felice (1996a, b, 1997) used extended 9-intersection model to classify forty-four topological relations between simple regions with broad boundaries. The extended 9-intersection model substantially agrees with the RCC model, though the former removes two relations considered as invalid in the geographical environment. The extended 9intersection model can be extended to represent topological relations between objects with different dimensions, like regions and lines, while the RCC model can only be applied to relations between regions. Tang and Kainz (2002), Tang et al. (2005), Tang (2004) applied fuzzy theory and a 9-intersection matrix and discovered forty-four topological relations between two simple fuzzy regions. Shi and Liu (2004) discussed fuzzy topological relations between fuzzy spatial objects based on the theory of fuzzy topology. Du et al. (2005a, b) proposed computational methods for fuzzy topological relations description, as well as a new fuzzy 9-intersection model. Liu and Shi (2006, 2009), Shi and Liu(2007) defined a computational fuzzy topology to compute the interior, boundary, and exterior parts of spatial objects, and based on the definition, Liu and Shi(2009) proposed a computational 9-intersection model to compute the topological relations between simple fuzzy region, line segment and fuzzy points, but the model did not give the topological relations between two simple fuzzy regions, and did not compute the topological relations between one simple fuzzy spatial object and one simple crisp spatial object.

To further investigate the application of fuzzy topological relations in GIS, on the basis of previous researches, this study develops a new model of describing the fuzzy topological relations for simple fuzzy objects. The new model not only computes the topological relations between simple crisp spatial objects, but also computes the topological relations between simple fuzzy spatial objects.

The remainder of this paper is organized as follows. In section 2, some basic concepts of fuzzy topology, computational fuzzy topology and the definitions of simple fuzzy spatial objects in GIS are detailed; In the Section 3, the new definition of simple fuzzy spatial objects is presented, and a new model of fuzzy topological relations for simple fuzzy spatial objects is proposed; In Section 4, some examples are discussed to validate the proposed method. Finally, some conclusions are drawn in Section 5.

\section{A BRIEF SUMMARY OF COMPUTATIONAL FUZZY}

\section{TOPOLOGY}

In this section, coherent fuzzy topologies, induced by interior and closure operators (Liu and Shi, 2006, 2009; Shi and Liu, 2007; Liu and Luo, 1997), are reviewed. Mathematically, point set topology is the fundamental theory for modeling topological relations between simple crisp spatial objects in GIS. By extension, fuzzy topology is a generalization of ordinary topology that 
introduces the concept of membership value and can be adopted for modeling topological relations between spatial objects with uncertainties. Zadeh (1965) introduced the concept of fuzzy sets, and fuzzy set theory. Fuzzy topology was further developed based on the fuzzy sets (Chang, 1968; Wong, 1974; Wu and Zheng, 1991; Liu and Luo, 1997).Liu and Shi (2006, 2009), and Shi and Liu (2007) defined a computational fuzzy topology to compute the interior, boundary and exterior of spatial objects. The computation is based on two operators, the interior operator and the closure operator. Each interior operator corresponds to one fuzzy topology and that each closure operator also corresponds to one fuzzy topology (Liu and Luo, 1997). The research detailed in this paper extends this work by defining fuzzy spatial objects. However, it is important to review basic concepts in fuzzy set theory as well as simple fuzzy objects in GIS.

\subsection{Basic Concepts}

We focus on the two-dimensional Euclidean plane $R^{2}$, with the usual distance and topology. Fuzzy topology is an extension of ordinary topology that fuses two structures, the order and topological structures. Fuzzy interiors, boundaries, and exteriors play an important role in the uncertain relations between GIS objects. In this section we first present the basic definitions for fuzzy sets, and then the definitions for fuzzy mapping.

Definition 2.1 (Fuzzy subset). Let $X$ be a non-empty ordinary set and $I$ be the closed interval [0, $1]$.

An $I$-fuzzy subset on $X$ is a mapping $\mu_{A}: X \rightarrow I$, i.e., the family of all the [0,1]-fuzzy or $I$-fuzzy subsets on $X$ is just $I^{X}$; consisting of all the mappings from $X$ to $I$. Here, $I^{X}$ is called an $I$-fuzzy space. $X$ is called the carrier domain of each $I$-fuzzy subset in it, and $I$ is called the value domain of each $I$-fuzzy subset on $X . A \in I^{X}$ is called a crisp subset on $X$, if the image of the mapping is the subset of $\{0,1\} \subset I$.

Definition 2.2 (Rules of set relations). Let $A$ and $B$ be fuzzy sets in $X$ with membership functions $\mu_{A}(x)$ and $\mu_{B}(x)$, respectively. Then,

1) $A=B$, iff $\mu_{A}(x)=\mu_{B}(x)$ for all $x$ in $X$;

2) $A \leq B$, iff $\mu_{A}(x) \leq \mu_{B}(x)$ for all $x$ in $X$;

3) $C=A \vee B$, iff $\mu_{C}(x)=\max \left[\mu_{A}(x), \mu_{B}(x)\right]$ for all $x$ in $X$;

4) $D=A \wedge B$, iff $\mu_{D}(x)=\min \left[\mu_{A}(x), \mu_{B}(x)\right]$ for all $x$ in $X$;

5) $E=X \backslash A$, iff $\mu_{E}(x)=1-\mu_{A}(x)$ for all $x$ in $X$. 
Definition 2.3 (Fuzzy topological space). Let $X$ be a non-empty ordinary set and $I=[0,1], \delta \subset I^{X}$ .$\delta$ is called an $I$-fuzzy topology on $X$, and $\left(I^{X}, \delta\right)$ is called an $I$-fuzzy topological space ( $I$-fts), if $\delta$ satisfies the following conditions:

1) $0,1 \in \delta$,2) If $A, B \in \delta$, then $A \wedge B \in \delta$, then 3) Let $\left\{A_{i}: i \in J\right\} \subset \delta$, where $\mathrm{J}$ is an index set, and $\vee_{i \in J} A_{i} \in \delta$

Where, $0 \in \delta$ means the empty set and $1 \in \delta$ means the whole set $X$. The elements in $\delta$ are called open elements and the elements in the complement of $\delta$ are called closed elements, and the set of the complement of an open set is denoted by $\delta^{\prime}$.

Definition 2.4 (Interior and closure). For any fuzzy set $A \in I^{X}$, the interior of $A$ is defined as the join of all the open subsets contained in $A$, denoted by $A^{\circ}$. The closure of $\mathrm{A}$ is defined as the meeting of all the closed subsets containing A; denoted by $\bar{A}$.

Definition 2.5 (Fuzzy complement). For any fuzzy set $A$, we defined the complements of $A$ by $A^{C}(x)=1-A(x)$; denoted by $A^{C}$.

Definition 2.6 (Fuzzy boundary). The boundary of a fuzzy set $A$ is defined as: $\partial A=\bar{A} \wedge \overline{A^{C}}$.

Definition 2.7 (Closure operator). An operator $\alpha: I^{X} \rightarrow I^{X}$ is a fuzzy closure operator if the following conditions are satisfied:

1) $\alpha(0)=0$; 2) $\alpha(A) \leq A$, for all $A \in I^{X}$; 3) $\alpha(A \vee B)=\alpha(A) \vee \alpha(B)$; 4) $\alpha(\alpha(A))=\alpha(A)$, for all $A \in I^{X}$.

Definition 2.8 (Interior operator). An operator $\alpha: I^{X} \rightarrow I^{X}$ is a fuzzy interior operator if the following conditions are satisfied:

1) $\alpha(1)=1$; 2) $A \leq \alpha(A)$, for all $A \in I^{X}$; 3) $\alpha(A \vee B)=\alpha(A) \wedge \alpha(B)$; 4) $\alpha(\alpha(A))=\alpha(A)$, for all $A \in I^{X}$

Definition 2.9 (Interior and closure operators). For any fixed $\alpha \in[0,1]$, both operators, interior and closure, are defined as $A_{\alpha}(x)=\left\{\begin{array}{lll}A(x) & \text { if } & A(x)>\alpha \\ 0 & \text { if } \quad A(x) \leq \alpha\end{array}\right.$ and $A^{1-\alpha}(x)=\left\{\begin{array}{ll}1 & \text { if } \quad A(x) \geq 1-\alpha \\ A(x) & \text { if } \quad A(x)<1-\alpha\end{array}\right.$ respectively, and can induce an $I$-fuzzy topology $\left(X, \tau_{\alpha}, \tau^{1-\alpha}\right)$ in $X$, where $\tau_{\alpha}=\left\{A_{\alpha}: A \in I^{X}\right\}$ are the open sets and Bol. Ciênc. Geod., sec. Artigos, Curitiba, v. 21, no 2, p.389-408, abr-jun, 2015. 
$\tau^{1-\alpha}=\left\{A^{1-\alpha}: A \in I^{X}\right\}$ are the closed sets. The elements in $\tau_{\alpha}$ and $\tau^{1-\alpha}$ satisfy the relations $\left(A_{\alpha}\right)^{C}=\left(A^{C}\right)^{1-\alpha}$, for all fuzzy sets $A$, i.e., the complement of the elements in the $\tau_{\alpha}$ closed set. Details on how these two operators can induce a coherent $I$-fuzzy topology are given in Liu and Shi (2006).

To study topological relations, it is essential to first understand the properties of fuzzy mapping, especially homeomorphic mapping since topological relations are invariant in homeomorphic mappings. The following section presents a number of definitions related to fuzzy mapping.

Let $I^{X}, I^{Y}$ be $I$-fuzzy spaces, $f: X \rightarrow Y$ an ordinary mapping. Based on $f: X \rightarrow Y$, define $I$-fuzzy mapping $f^{\rightarrow}: I^{X} \rightarrow I^{Y}$ and its $I$-fuzzy reverse mapping $f^{\rightarrow}: I^{X} \rightarrow I^{Y}$ by

$$
\begin{aligned}
& f^{\rightarrow}: I^{X} \rightarrow I^{Y}, f^{\rightarrow}(A)(y)=\left\{\begin{array}{ll}
V\{A(x)\}, \text { if } & x \in f^{-1}(y) \\
0 \quad, & \text { otherwise }
\end{array} \quad, \forall A \in I^{X}, \forall y \in Y\right. \\
& f^{\leftarrow}: I^{Y} \rightarrow I^{X}, f^{\leftarrow}(B)(x)=B(f(x)), \forall B \in I^{Y}, \forall x \in X
\end{aligned}
$$

While $I=[0,1]$.

Let $\left(I^{X}, \delta\right),\left(I^{Y}, \delta\right)$ be $I$-fts's, $f^{\rightarrow}:\left(I^{X}, \delta\right) \rightarrow\left(I^{Y}, \mu\right)$ is called $I$-fuzzy homeomorphism, if it is bijective, continuous, and open (Liu and Luo, 1997). One important theorem to check an I-fuzzy homeomorphism is that, as proved by Shi and Liu (2007). Let $A \in I^{X}, B \in I^{Y}, \operatorname{let}\left(I^{X}, \delta\right),\left(I^{Y}, \delta\right)$ be $I$-fts's induced by an interior operator and closure operators. Then $f^{\rightarrow}:\left(I^{X}, \delta\right) \rightarrow\left(I^{Y}, \mu\right)$ is an $I$ fuzzy homeomorphism if and only if $f: X \rightarrow Y$ is a bijective mapping. Meanwhile, for the topology induced by these two operators, when checking a homeomorphic map, we only have to check whether there is a one-to-one correspondence between the domain and range.

\subsection{Fuzzy Simple Spatial Objects in GIS}

Based on the definitions presented in section 2.1, Liu and Shi developed fuzzy definitions for the basic elements in GIS (Liu and Shi, 2006, 2009; Shi and Liu, 2007), summarized here as follows:

Definition 2.10 (fuzzy point, Figure 1(a)). An $I$-fuzzy point on $X$ is an $I$-fuzzy subset $X_{\alpha} \in I^{X}$, defined as: $x_{\alpha}(y)=\left\{\begin{array}{ll}\alpha & \text { if } y=x \\ 0 & \text { otherwise }\end{array}\right.$. 
Definition 2.11 (Simple fuzzy line, Figure 1(b)). A fuzzy subset in $X$ is called a simple fuzzy line $(L)$ if $L$ is a supported connected line in the background topology (i.e., a crisp line in the background topology).

Definition 2.12 (Simple fuzzy line segment, Figure 1(b)). The simple fuzzy line segment $(L)$ is a fuzzy subset in $X$ with: 1) for any $\alpha \in(0,1)$, the fuzzy line $L_{\alpha}$ is a supported connected line segment (i.e., a crisp line segment in the background topology) in the background topology and 2) $\partial L\left(=\left(L_{\alpha}\right)^{C} \wedge L^{1-\alpha}\right)$ has at most two supported connected components.

Definition 2.13 (Simple fuzzy region, Figure 1(c)). A simple fuzzy region is a fuzzy region in $X$ where: 1) for any $\alpha \in(0,1)$, the fuzzy set $A_{\alpha}$ and $\partial A\left(A_{\alpha}\right)^{C} \wedge A^{1-\alpha}$ are two supported connected regular bounded open sets in the background topological space. And, 2) in the background topological space, any outward normal from Supp $\left(A_{\alpha}\right)$ must meet Supp $(\partial A)$ and have only one component.

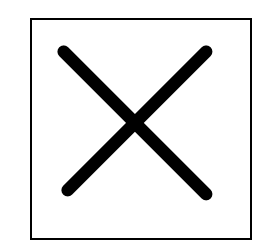

(a)Fuzzy point

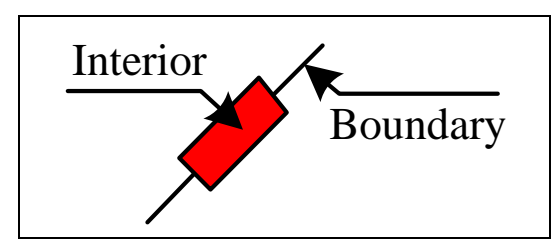

(b) Fuzzy line segment

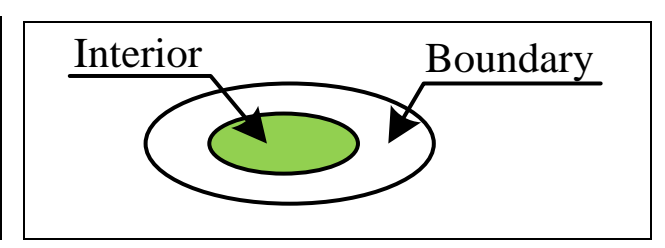

(c) Fuzzy region

Figure1: (a) Fuzzy point for a given $\alpha$; (b) Fuzzy line segment for a given $\alpha$; (c) Fuzzy region for a given $\alpha$ (Liu and Shi 2009)

On the basis of definitions for simple fuzzy points, line segments and regions, Shi and Liu (2007) provide an example of computing the interior, boundary, and exterior of spatial objects for different $\alpha$ values, and the interior, boundary, and exterior of spatial objects were confirmed for each given $\alpha$ value. Based on the fuzzy definitions, Liu and Shi (2009) proposed a new $3 \times 3$ integration model to compute the topological relations between simple fuzzy region, line segment and fuzzy points. The element $\left(f_{X} A \wedge B d V\right)$ of the new $3 \times 3$ integration model is the ratio of the area( or volume) of the meet of two fuzzy spatial objects in a join of two simple spatial object(here a join of two fuzzy objects means "union" of two fuzzy objects; a meet of two fuzzy objects means "intersection" of two fuzzy objects(Liu and Shi, 2009)). And it was difficult to change or transform the new $3 \times 3$ integration model to describe the topological relations between one simple crisp spatial object and one simple fuzzy spatial object.

Based on existing related studies, in the next section, we will discuss the method of fuzzy topological relations for simple spatial objects. 


\section{Modeling Fuzzy Topological Relations for Simple Spatial Objects in Gis}

\subsection{A New Definition for Simple Fuzzy Spatial Objects}

Based on section 2, we developed a new definition for a simple fuzzy spatial line segment and region by applying the definition presented in this section. On fuzzy topological space (Chang, 1968), the fuzzy point definition remains the same as Definition 2.10.

Definition 2.14 (inner and outer boundary of simple fuzzy line segment, Figure 2(a)), for given $\alpha$, the interior and boundary of simple line segment $L($ as shown in figurel $(b))$ are confirmed, separately, can be regarded as a simple crisp line segment. Therefore, we define $\partial L_{\alpha}^{-}$as the outerboundary of $L$, and $\partial L_{\alpha}^{o}$ as the inner-boundary of $L, L_{\alpha}^{o}$ as the interior of $L$, and $\partial L_{\alpha}$ as the boundary of $L($ as shown in figure $4(a)): \partial L_{\alpha}=\partial L_{\alpha}^{-}-\partial L_{\alpha}^{o}$. So, a simple fuzzy line segment $L$ for given $\alpha$ can be written as: $L_{\alpha}=\partial L_{\alpha}^{-} \cup \partial L_{\alpha} \cup \partial L_{\alpha}^{o} \cup L_{\alpha}^{o}$.

Definition 2.15 (inner and outer boundary of simple fuzzy region, Figure 2(b)), for a given $\alpha$ , the interior and boundary of fuzzy region $A$ (as shown in figure l(c)) is confirmed, separately, can be regarded as a simple crisp region. Therefore, we defined $\partial A_{\alpha}^{-}$as the outer-boundary of $A$, and $\partial A_{\alpha}^{o}$ as the inner-boundary of $A, A_{\alpha}^{o}$ as the interior of $A$ and $\partial A_{\alpha}$ as the boundary of $A$ (as shown in figure4 (b)): $\partial A_{\alpha}=\partial A_{\alpha}^{-}-\partial A_{\alpha}^{o}$. So the fuzzy region $A$ for given $\alpha$ can be expressed as: $A_{\alpha}=\partial A_{\alpha}^{-} \cup \partial A_{\alpha} \cup \partial A_{\alpha}^{o} \cup A_{\alpha}^{o}$. Meanwhile, $\partial A_{\alpha}^{-}$and $\partial A_{\alpha}^{o}$ can be considered as two simple crisp regions.

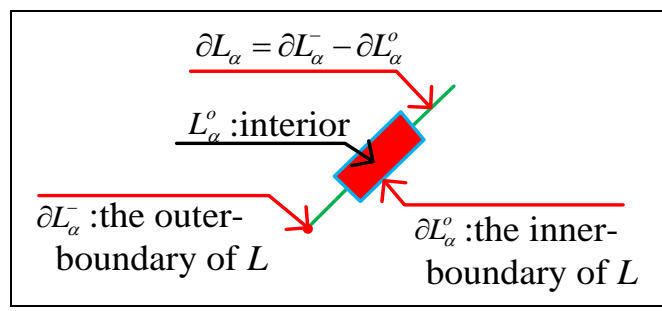

(a) Fuzzy line segment $L$

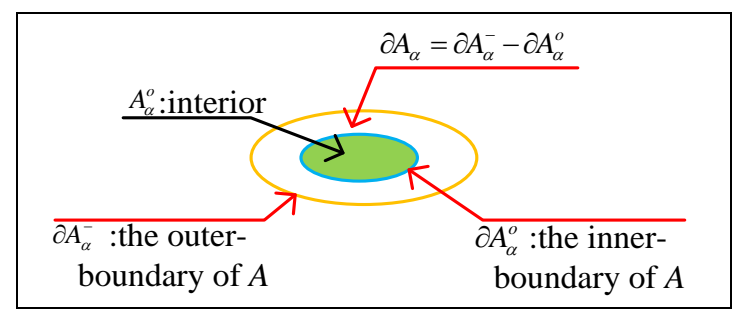

(b) Fuzzy region $A$

Figure 2: (a) The inner-outer boundary of simple fuzzy line segment $L$ for given $\alpha$; (b) The inner-outer boundary of simple fuzzy region $A$ for given $\alpha$

Based on the above definitions, (1) to a simple fuzzy line segment $L$ for given $\alpha$, if $\partial L_{\alpha}^{-}=\partial L_{\alpha}^{o}$, that is $\partial L_{\alpha}=0$, and $L=L_{\alpha}=\partial L_{\alpha}^{-} \cup L_{\alpha}^{o}$, it means $L$ is a simple crisp line segment; (2) to a fuzzy region $A$ for given $\alpha$, if $\partial A_{\alpha}^{-}=\partial A_{\alpha}^{o}$, that is $\partial A_{\alpha}=0, A=A_{\alpha}=\partial A_{\alpha}^{-} \cup A_{\alpha}^{o}$, it means $A$ is a simple crisp region. Bol. Ciênc. Geod., sec. Artigos, Curitiba, v. 21, no 2, p.389-408, abr-jun, 2015. 
Based on these definitions, the next section will primarily focus on discussing the new model of fuzzy topological relations for simple spatial objects.

\subsection{A New Model of the Fuzzy Topological Relations for Simple Spatial}

\section{Objects}

In this paper, we just discussed the topological relations between two simple fuzzy line segments, the topological relations one simple fuzzy line segment and one simple fuzzy region, and the topological relations between two simple fuzzy regions, as follows.

\section{(I) Topological relations between two simple fuzzy line segments}

For one simple fuzzy line segment $L 1$ for given $\alpha$ (figure3 (a)), and the other simple fuzzy line segment $L 2$ for given $\beta$ (figure3 (b)). The topological relations between $L 1$ and $L 2$ can be computed by $4 \times 4$ intersection model as equation (1).

$$
R\left(L 1_{\alpha}, L 2_{\beta}\right)=\left[\begin{array}{llll}
\partial L 1_{\alpha}^{-} \cap \partial L 2_{\beta}^{-} & \partial L 1_{\alpha}^{-} \cap \partial L 2_{\beta} & \partial L 1_{\alpha}^{-} \cap \partial L 2_{\beta}^{o} & \partial L 1_{\alpha}^{-} \cap L 2_{\beta}^{o} \\
\partial L 1_{\alpha} \cap \partial L 2_{\beta}^{-} & \partial L 1_{\alpha} \cap \partial L 2_{\beta} & \partial L 1_{\alpha} \cap \partial L 2_{\beta}^{o} & \partial L 1_{\alpha} \cap L 2_{\beta}^{o} \\
\partial L 1_{\alpha}^{o} \cap \partial L 2_{\beta}^{-} & \partial L 1_{\alpha}^{o} \cap \partial L 2_{\beta} & \partial L 1_{\alpha}^{o} \cap \partial L 2_{\beta}^{o} & \partial L 1_{\alpha}^{o} \cap L 2_{\beta}^{o} \\
L 1_{\alpha}^{o} \cap \partial L 2_{\beta}^{-} & L 1_{\alpha}^{o} \cap \partial L 2_{\beta} & L 1_{\alpha}^{o} \cap \partial L 2_{\beta}^{o} & L 1_{\alpha}^{o} \cap L 2_{\beta}^{o}
\end{array}\right]
$$

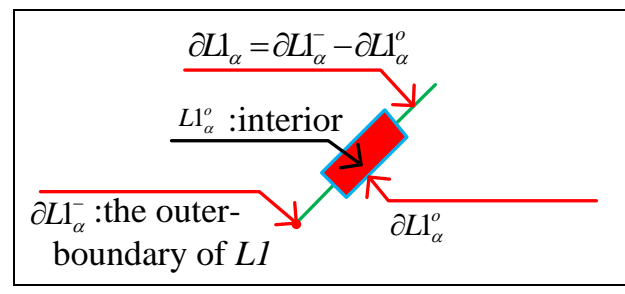

(a)

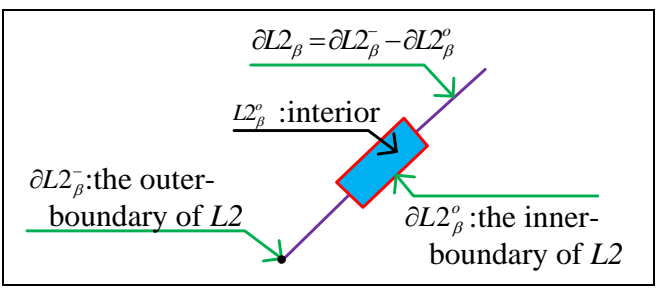

(b)

Figure 3: (a) A simple fuzzy line segment $L 1$ for given $\alpha$; (b) A simple fuzzy line segment $L 2$ for given $\beta$

There are three different topological relations between $L 1$ and $L 2$, as follows:

1) if $\partial L 1_{\alpha}^{-}=\partial L 1_{\alpha}^{o}$, that is $\partial L 1_{\alpha}=0, L 1=L 1_{\alpha}=\partial L 1_{\alpha}^{-} \cup L 1_{\alpha}^{o} ; \quad$ if $\partial L 2_{\beta}^{-}=\partial L 2_{\beta}^{o}$, that is $\partial L 2_{\beta}=0$, $L 2=L 2_{\beta}=\partial L 2_{\beta}^{-} \cup L 2_{\beta}^{o}$. Thus, $L 1$ and $L 2$ are crisp line segments, the equation (1) can be turned into 4-Intersection Model (4IM) (Egenhofer and Franzosa, 1991a) or 9-Intersection Model (9IM) 
(Egenhofer and Franzosa, 1991b), the topological relations between $L 1$ and $L 2$ are computed by 4IM or 9IM.

2) If $\partial L 1_{\alpha}^{-}=\partial L 1_{\alpha}^{o}$, that is $\partial L 1_{\alpha}=0, L 1=L 1_{\alpha}=\partial L 1_{\alpha}^{-} \cup L 1_{\alpha}^{o}, L 1$ is a simple crisp line segment. If $\partial L 2_{\beta}^{-} \neq \partial L 2_{\beta}^{o}$, that is $\partial L 2_{\beta} \neq 0, L 2=L 2_{\beta}=\partial L 2_{\beta}^{-} \cup \partial L 2_{\beta} \cup \partial L 2_{\beta}^{o} \cup L 2_{\beta}^{o}, L 2$ is a simple fuzzy line segment, and comprised of four components $\partial L 2_{\beta}^{-}, \partial L 2_{\beta}, \partial L 2_{\beta}^{o}$ and $L 2_{\beta}^{o}$, while $\partial L 2_{\beta}=\partial L 2_{\beta}^{-}-\partial L 2_{\beta}^{o}$. The equation (1) can be turned into $2 \times 4$ intersection model as equation (2).

$$
R\left(L 1_{\alpha}, L 2_{\beta}\right)=\left[\begin{array}{llll}
\partial L 1_{\alpha} \cap \partial L 2_{\beta}^{-} & \partial L 1_{\alpha} \cap \partial L 2_{\beta} & \partial L 1_{\alpha} \cap \partial L 2_{\beta}^{o} & \partial L 1_{\alpha} \cap L 2_{\beta}^{o} \\
L 1_{\alpha}^{o} \cap \partial L 2_{\beta}^{-} & L 1_{\alpha}^{o} \cap \partial L 2_{\beta} & L 1_{\alpha}^{o} \cap \partial L 2_{\beta}^{o} & L 1_{\alpha}^{o} \cap L 2_{\beta}^{o}
\end{array}\right]
$$

3) If $\partial L 1_{\alpha}^{-} \neq \partial L 1_{\alpha}^{o}$, that is $\partial L 1_{\alpha} \neq 0, L 1=L 1_{\alpha}=\partial L 1_{\alpha}^{-} \cup \partial L 1_{\alpha} \cup \partial L 1_{\alpha}^{o} \cup L 1_{\alpha}^{o}, L 1$ is a simple fuzzy line segment, and comprised of four components $\partial L 1_{\alpha}^{-}, \partial L 1_{\alpha}, \partial L 1_{\alpha}^{o}$ and $L 1_{\alpha}^{o}$, in addition, $\partial L 1_{\alpha}=\partial L 1_{\alpha}^{-}-\partial L 1_{\alpha}^{o}$. If $\partial L 2_{\beta}^{-} \neq \partial L 2_{\beta}^{o}$, that is $\partial L 2_{\beta} \neq 0, L 2=L 2_{\beta}=\partial L 2_{\beta}^{-} \cup \partial L 2_{\beta} \cup \partial L 2_{\beta}^{o} \cup L 2_{\beta}^{o}$,

$L 2$ is a simple fuzzy line segment too, comprised of four components $\partial L 2_{\beta}^{-}, \partial L 2_{\beta}, \partial L 2_{\beta}^{o}$ and $L 2_{\beta}^{o}$ , in addition, $\partial L 2_{\beta}=\partial L 2_{\beta}^{-}-\partial L 2_{\beta}^{o}$. Thus, the topological relations between $L 1$ and $L 2$ can be computed by $4 \times 4$ intersection model as equation (1).

(II)Topological relations between one simple fuzzy line segment and one simple fuzzy region For one simple fuzzy line segment $L 1$ for a given $\alpha$ (figure4 (a)), there is one simple fuzzy region $A 1$ for given $\beta$ (figure 4 (b)). The topological relations between $L 1$ and $A l$ can be computed by $4 \times 4$ intersection model as equation (3).

$$
R\left(L_{\alpha}, A_{\beta}\right)=\left[\begin{array}{llll}
\partial L_{\alpha}^{-} \cap \partial A_{\beta}^{-} & \partial L_{\alpha}^{-} \cap \partial A_{\beta} & \partial L_{\alpha}^{-} \cap \partial A_{\beta}^{o} & \partial L_{\alpha}^{-} \cap A_{\beta}^{o} \\
\partial L_{\alpha} \cap \partial A_{\beta}^{-} & \partial L_{\alpha} \cap \partial A_{\beta} & \partial L_{\alpha} \cap \partial A_{\beta}^{o} & \partial L_{\alpha} \cap A_{\beta}^{o} \\
\partial L_{\alpha}^{o} \cap \partial A_{\beta}^{-} & \partial L_{\alpha}^{o} \cap \partial A_{\beta} & \partial L_{\alpha}^{o} \cap \partial A_{\beta}^{o} & \partial L_{\alpha}^{o} \cap A_{\beta}^{o} \\
L_{\alpha}^{o} \cap \partial A_{\beta}^{-} & L_{\alpha}^{o} \cap \partial A_{\beta} & L_{\alpha}^{o} \cap \partial A_{\beta}^{o} & L_{\alpha}^{o} \cap A_{\beta}^{o}
\end{array}\right]
$$

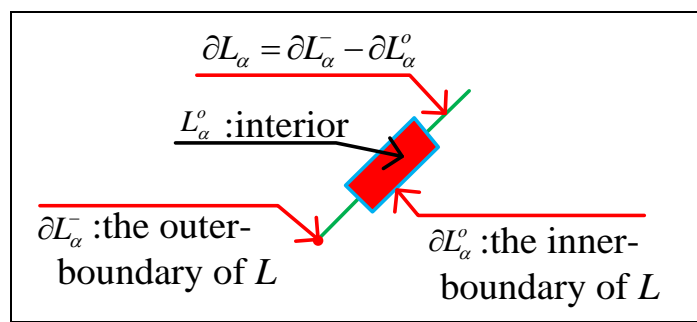

(a)

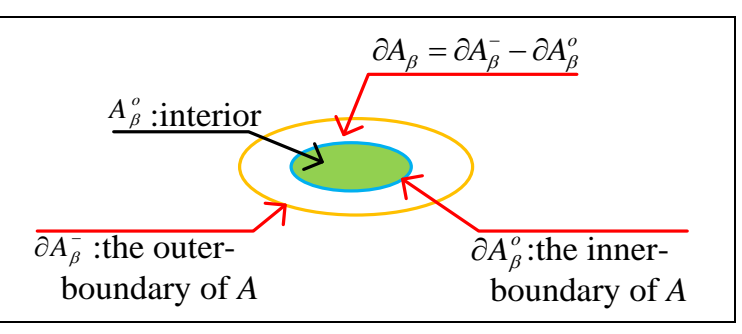

(b)

Figure 4: (a) A simple fuzzy line segment $L$ for given $\alpha$; (b)A simple fuzzy region $A$ for given $\beta$ Bol. Ciênc. Geod., sec. Artigos, Curitiba, v. 21, no 2, p.389-408, abr-jun, 2015. 
There are four different topological relations between $L 1$ and $A 1$, as follows:

1) If $\partial L_{\alpha}^{-}=\partial L_{\alpha}^{o}$, that is $\partial L_{\alpha}=0, L=L_{\alpha}=\partial L_{\alpha}^{-} \cup L_{\alpha}^{o}, L$ is a simple crisp line segment. If $\partial A_{\beta}^{-}=\partial A_{\beta}^{o}$, that is $\partial A_{\beta}=0, A=A_{\beta}=\partial A_{\beta}^{-} \cup A_{\beta}^{o}$, and $A$ is a simple crisp region. The equation (3) can be turned into 4-Intersection Model (4IM) (Egenhofer and Franzosa, 1991a) or 9-Intersection Model (9IM) (Egenhofer and Franzosa, 1991b), the topological relations between $L$ and $A$ are computed by 4IM or 9IM.

2) If $\partial L_{\alpha}^{-}=\partial L_{\alpha}^{o}$, that is $\partial L_{\alpha}=0, L=L_{\alpha}=\partial L_{\alpha}^{-} \cup L_{\alpha}^{o}, L$ is a simple crisp line segment. If $\partial A_{\beta}^{-} \neq \partial A_{\beta}^{o}$, that is $\partial A_{\beta} \neq 0, \quad A=A_{\beta}=\partial A_{\beta}^{-} \cup \partial A_{\beta} \cup \partial A_{\beta}^{o} \cup A_{\beta}^{o}, A$ is a simple fuzzy region, comprised of four components $\partial A_{\beta}^{-}, \partial A_{\beta}, \partial A_{\beta}^{o}$ and $A_{\beta}^{o}$, in addition, $\partial A_{\beta}=\partial A_{\beta}^{-}-\partial A_{\beta}^{o}$. The equation (3) can be turned into $2 \times 4$ intersection model as equation (4).

$$
R\left(L_{\alpha}, A_{\beta}\right)=\left[\begin{array}{llll}
\partial L_{\alpha} \cap \partial A_{\beta}^{-} & \partial L_{\alpha} \cap \partial A_{\beta} & \partial L_{\alpha} \cap \partial A_{\beta}^{o} & \partial L_{\alpha} \cap A_{\beta}^{o} \\
L_{\alpha}^{o} \cap \partial A_{\beta}^{-} & L_{\alpha}^{o} \cap \partial A_{\beta} & L_{\alpha}^{o} \cap \partial A_{\beta}^{o} & L_{\alpha}^{o} \cap A_{\beta}^{o}
\end{array}\right]
$$

3) If $\partial L_{\alpha}^{-} \neq \partial L_{\alpha}^{o}$, that is $\partial L_{\alpha} \neq 0, L=L_{\alpha}=\partial L_{\alpha}^{-} \cup \partial L_{\alpha} \cup \partial L_{\alpha}^{o} \cup L_{\alpha}^{o}, L$ is a simple fuzzy line segment, comprised of four components $\partial L_{\alpha}^{-}, \partial L_{\alpha}, \partial L_{\alpha}^{o}$ and $L_{\alpha}^{o}$, in addition, $\partial L_{\alpha}=\partial L_{\alpha}^{-}-\partial L_{\alpha}^{o}$.If $\partial A_{\beta}^{-}=\partial A_{\beta}^{o}$, that is $\partial A_{\beta}=0, A=A_{\beta}=\partial A_{\beta}^{-} \cup A_{\beta}^{o}, A$ is a simple crisp region. The equation (3) can be turned into $2 \times 4$ intersection model too, as equation (5).

$$
R\left(L_{\alpha}, A_{\beta}\right)=\left[\begin{array}{cccc}
\partial A_{\beta} \cap \partial L_{\alpha}^{-} & \partial A_{\beta} \cap \partial L_{\alpha} & \partial A_{\beta} \cap \partial L_{\alpha}^{o} & \partial A_{\beta} \cap L_{\alpha}^{o} \\
A_{\beta}^{o} \cap \partial L_{\alpha}^{-} & A_{\beta}^{o} \cap \partial L_{\alpha} & A_{\beta}^{o} \cap \partial L_{\alpha}^{o} & A_{\beta}^{o} \cap L_{\alpha}^{o}
\end{array}\right]
$$

4) If $\partial L_{\alpha}^{-} \neq \partial L_{\alpha}^{o}$, that is $\partial L_{\alpha} \neq 0, L=L_{\alpha}=\partial L_{\alpha}^{-} \cup \partial L_{\alpha} \cup \partial L_{\alpha}^{o} \cup L_{\alpha}^{o}, L$ is a simple fuzzy line segment, comprised of four components $\partial L_{\alpha}^{-}, \partial L_{\alpha}, \partial L_{\alpha}^{o}$ and $L_{\alpha}^{o}$, in addition, $\partial L_{\alpha}=\partial L_{\alpha}^{-}-\partial L_{\alpha}^{o}$.If $\partial A_{\beta}^{-} \neq \partial A_{\beta}^{o}$, that is $\partial A_{\beta} \neq 0, A=A_{\beta}=\partial A_{\beta}^{-} \cup \partial A_{\beta} \cup \partial A_{\beta}^{o} \cup A_{\beta}^{o}, A$ is a simple fuzzy region, comprised of four components $\partial A_{\beta}^{-}, \partial A_{\beta}, \partial A_{\beta}^{o}$ and $A_{\beta}^{o}$, in addition, $\partial A_{\beta}=\partial A_{\beta}^{-}-\partial A_{\beta}^{o}$. The topological relations between $L$ and $A$ can be computed by $4 \times 4$ intersection model as equation (3).

\section{(III) Topological relations between two simple fuzzy regions}

For one simple fuzzy region $A 1$ for given $\alpha$ (figure5 (a)), the other simple fuzzy region $A 2$ for given $\beta$ (figure5 (b)). The topological relations between $A 1$ and $A 2$ can be computed by $4 \times 4$ intersection model as equation (6). 


$$
R\left(A 1_{\alpha}, A 2_{\beta}\right)=\left[\begin{array}{llll}
\partial A 1_{\alpha}^{-} \cap \partial A 2_{\beta}^{-} & \partial A 1_{\alpha}^{-} \cap \partial A 2_{\beta} & \partial A 1_{\alpha}^{-} \cap \partial A 2_{\beta}^{o} & \partial A 1_{\alpha}^{-} \cap A 2_{\beta}^{o} \\
\partial A 1_{\alpha} \cap \partial A 2_{\beta}^{-} & \partial A 1_{\alpha} \cap \partial A 2_{\beta} & \partial A 1_{\alpha} \cap \partial A 2_{\beta}^{o} & \partial A 1_{\alpha} \cap A 2_{\beta}^{o} \\
\partial A 1_{\alpha}^{o} \cap \partial A 2_{\beta}^{-} & \partial A 1_{\alpha}^{o} \cap \partial A 2_{\beta} & \partial A 1_{\alpha}^{o} \cap \partial A 2_{\beta}^{o} & \partial A 1_{\alpha}^{o} \cap A 2_{\beta}^{o} \\
A 1_{\alpha}^{o} \cap \partial A 2_{\beta}^{-} & A 1_{\alpha}^{o} \cap \partial A 2_{\beta} & A 1_{\alpha}^{o} \cap \partial A 2_{\beta}^{o} & A 1_{\alpha}^{o} \cap A 2_{\beta}^{o}
\end{array}\right]
$$

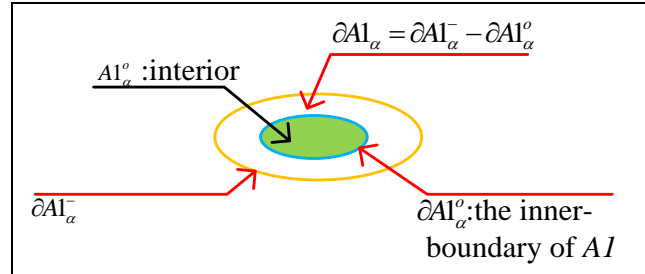

(a)

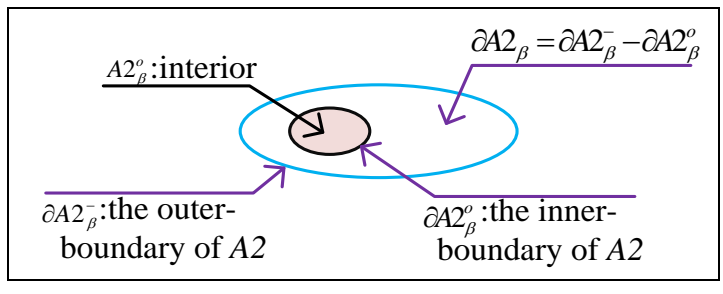

(b)

Figure 5: (a) A simple fuzzy region $A 1$ for given $\alpha$; (b) A simple fuzzy region $A 2$ for given $\beta$ There are three different topological relations between $A 1$ and $A 2$, as follows:

1) if $\partial A 1_{\alpha}^{-}=\partial A 1_{\alpha}^{o}$, that is $\partial A 1_{\alpha}=0, A 1=A 1_{\alpha}=\partial A 1_{\alpha}^{-} \cup A 1_{\alpha}^{o}, A 1$ is a simple crisp region. If $\partial A 2_{\beta}^{-}=\partial A 2_{\beta}^{o}$, that is $\partial A 2_{\beta}=0, A 2=A 2_{\beta}=\partial A 2_{\beta}^{-} \cup A 2_{\beta}^{o}, A 2$ is a simple crisp region too. Therefore, the equation (6) can be turned into 4-Intersection Model (4IM) (Egenhofer and Franzosa, 1991a) or 9-Intersection Model (9IM) (Egenhofer and Franzosa, 1991b), the topological relations between $A 1$ and $A 2$ are computed by 4IM or 9IM.

2) If $\partial A 1_{\alpha}^{-}=\partial A 1_{\alpha}^{o}$, that is $\partial A 1_{\alpha}=0, A 1=A 1_{\alpha}=\partial A 1_{\alpha}^{-} \cup A 1_{\alpha}^{o}, A 1$ is a simple crisp region. If $\partial A 2_{\beta}^{-} \neq \partial A 2_{\beta}^{o}$, that is $\partial A 2_{\beta} \neq 0, A 2=A 2_{\beta}=\partial A 2_{\beta}^{-} \cup \partial A 2_{\beta} \cup \partial A 2_{\beta}^{o} \cup A 2_{\beta}^{o}, A 2$ is a simple fuzzy region, comprised of four components $\partial A 2_{\beta}^{-}, \partial A 2_{\beta}, \partial A 2_{\beta}^{o}$ and $A 2_{\beta}^{o}$, in addition, $\partial A 2_{\beta}=\partial A 2_{\beta}^{-}-\partial A 2_{\beta}^{o}$. The equation (6) can be turned into $2 \times 4$ intersection model as equation(7).

$$
R\left(A 1_{\alpha}, A 2_{\beta}\right)=\left[\begin{array}{llll}
\partial A 1_{\alpha} \cap \partial A 2_{\beta}^{-} & \partial A 1_{\alpha} \cap \partial A 2_{\beta} & \partial A 1_{\alpha} \cap \partial A 2_{\beta}^{o} & \partial A 1_{\alpha} \cap A 2_{\beta}^{o} \\
A 1_{\alpha}^{o} \cap \partial A 2_{\beta}^{-} & A 1_{\alpha}^{o} \cap \partial A 2_{\beta} & A 1_{\alpha}^{o} \cap \partial A 2_{\beta}^{o} & A 1_{\alpha}^{o} \cap A 2_{\beta}^{o}
\end{array}\right]
$$

3) If $\partial A 1_{\alpha}^{-} \neq \partial A 1_{\alpha}^{o}$, that is $\partial A 1_{\alpha} \neq 0$, and $A 1=A 1_{\alpha}=\partial A 1_{\alpha}^{-} \cup \partial A 1_{\alpha} \cup \partial A 1_{\alpha}^{o} \cup A 1_{\alpha}^{o}, A 1$ is a simple fuzzy region, comprised of four components $\partial A 1_{\alpha}^{-}, \partial A 1_{\alpha}, \partial A 1_{\alpha}^{o}$ and $A 1_{\alpha}^{o}$, in addition, $\partial A 1_{\alpha}=\partial A 1_{\alpha}^{-}-\partial A 1_{\alpha}^{o}$. If $\partial A 2_{\beta}^{-} \neq \partial A 2_{\beta}^{o}$, that is $\partial A 2_{\beta} \neq 0, A 2=A 2_{\beta}=\partial A 2_{\beta}^{-} \cup \partial A 2_{\beta} \cup \partial A 2_{\beta}^{o} \cup A 2_{\beta}^{o}, A 2$ is a simple fuzzy region, comprised of four components $\partial A 2_{\beta}^{-}, \partial A 2_{\beta}, \partial A 2_{\beta}^{o}$ and $A 2_{\beta}^{o}$, in addition, 
$\partial A 2_{\beta}=\partial A 2_{\beta}^{-}-\partial A 2_{\beta}^{o}$. The topological relations between $A 1$ and $A 2$ can be computed by $4 \times 4$ intersection model as equation (6).

Through the above description, the equation(1), (3) and (6)are equivalent, only replacing the elements of the $4 \times 4$ intersection model, the 4 IM or 9IM, equation(2), (4), (5), (7) are only the new $4 \times 4$ intersection models'(equation(1), (3), (6)) exception, and all the equation can describe the topological relations respectively.

In this section, we develop a new $4 \times 4$ intersection model to compute the fuzzy topological relations between simple spatial objects. An analysis of the new model exposes: (1) the topological relations between two simple crisp line segments; (2) the topological relations between two simple fuzzy line segments; (3) the topological relations between one simple crisp line segment and one simple fuzzy line segment; (4) the topological relations between one simple crisp line segment and one simple crisp region; (5) the topological relations between one simple crisp line segment and one simple fuzzy region; (6) the topological relations between one simple fuzzy line segment and one simple crisp region; (7) the topological relations between one simple fuzzy line segment and one simple fuzzy region; (8) the topological relations between one simple crisp region and one simple fuzzy region; (9) the topological relations between two simple crisp regions; (10) the topological relations between two simple fuzzy regions.

In the next section, we will focus on taking some examples to demonstrate the validity of the new model by comparing with existing models.

\section{EXPERIMENT AND COMPARISON}

The new $4 \times 4$ intersection model can identify the topological relations between two simple spatial objects. The following content will take some examples to demonstrate the validity of the new model, and compare with the existing fuzzy models.

\subsection{Experiment Results}

In this section, we will take some examples to demonstrate the validity of the new model.

1) A simple crisp line segment $L 1$ (figure6 (a)), a simple fuzzy line segment $L 2$ for given $\beta=0.4$ (figure6 (b)).The topological relation between them was shown in figure 6(c). Since the intersection of two sets can be either 0 or 1, the topological relation between $L 1$ and $L 2$ can be computed by equation (2) as: $R(L 1, L 2)=\left[\begin{array}{llll}0 & 0 & 0 & 0 \\ 0 & 0 & 1 & 1\end{array}\right]$. 


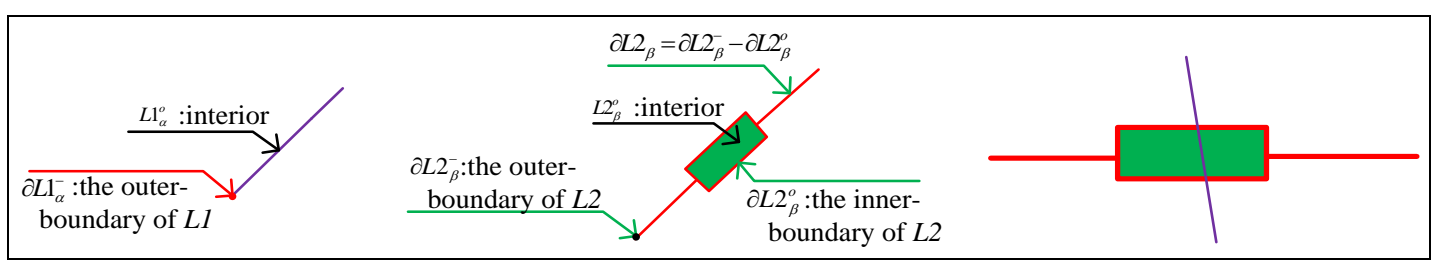

(a)

(b)

(c)

Figure 6: (a) Simple crisp line segment $L 1$; (b) Simple fuzzy line segment $L 2$ for given $\beta=0.4$;

(c) The topological relation between $L 1$ and $L 2$

2) A simple fuzzy line segment $L 1$ for given $\alpha=0.5$ (figure7 (a)), a simple fuzzy line segment $L 2$ for given $\beta=0.3$ (figure7 (b)). The topological relation between them was shown in figure7(c). Since the intersection of two sets can be either 0 or 1, the topological relation between $L 1$ and $L 2$ can be computed by equation (1) as:

$$
R(L 1, L 2)=\left[\begin{array}{llll}
0 & 1 & 0 & 1 \\
0 & 1 & 1 & 1 \\
0 & 1 & 0 & 0 \\
0 & 1 & 0 & 0
\end{array}\right]
$$

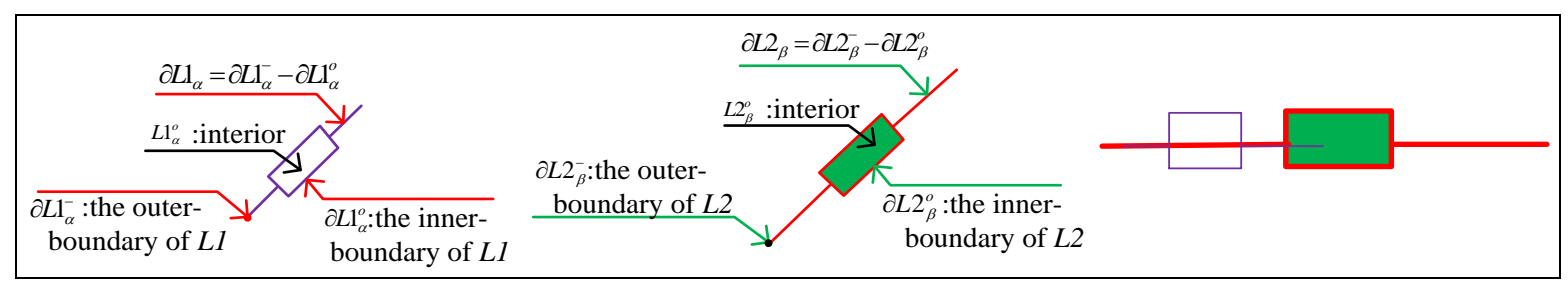

(a)

(b)

(c)

Figure 7: (a) Simple fuzzy line segment $L 1$ for given $\alpha=0.5$; (b) Simple fuzzy line segment $L 2$ for given $\beta=0.3$; (c) The topological relation between $L 1$ and $L 2$

3) A simple fuzzy line segment $L 1$ for given $\alpha=0.5$ (figure8 (a)), a simple fuzzy region $A 1$ for given $\beta=0.4$ (figure8 (b)). The topological relation between them was shown in figure8(c). Since the intersection of two sets can be either 0 or 1, the topological relation between $L 1$ and $A l$ can be computed by equation (3) as:

$$
R(L 1, A 1)=\left[\begin{array}{cccc}
0 & 0 & 0 & 1 \\
0 & 1 & 1 & 1 \\
1 & 1 & 0 & 0 \\
1 & 1 & 0 & 0
\end{array}\right]
$$




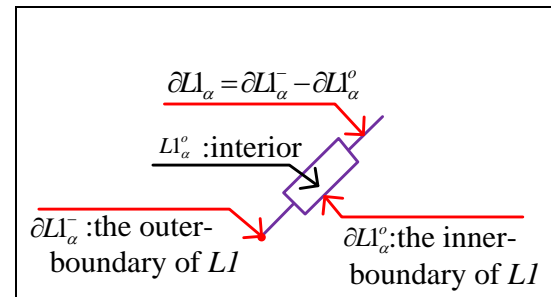

(a)

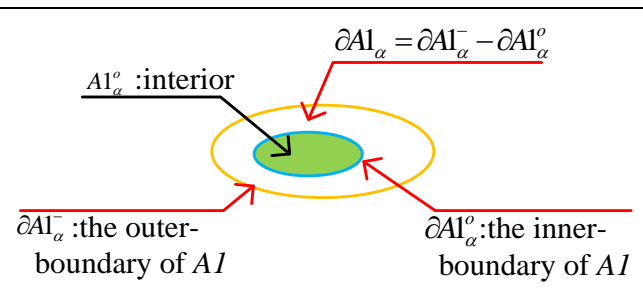

(b)

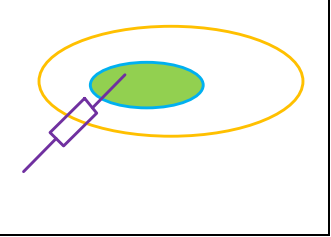

(c)

Figure 8: (a) Simple fuzzy line segment $L 1$ for given $\alpha=0.5$; (b) Simple fuzzy region $A 1$ for given $\beta=0.4$; (c) The topological relation between $L 1$ and $A 1$

4) A simple crisp line segment $L 1$ (figure9 (a)), a simple fuzzy region $A 1$ for given $\beta=0.4$ (figure 9(b)). The topological relation between them was shown in figure9(c). Since the intersection of two sets can be either 0 or 1 , the topological relation between $L 1$ and $A 1$ can be computed by equation (4) as: $R(L 1, A 1)=\left[\begin{array}{cccc}0 & 0 & 0 & 1 \\ 1 & 1 & 1 & 1\end{array}\right]$

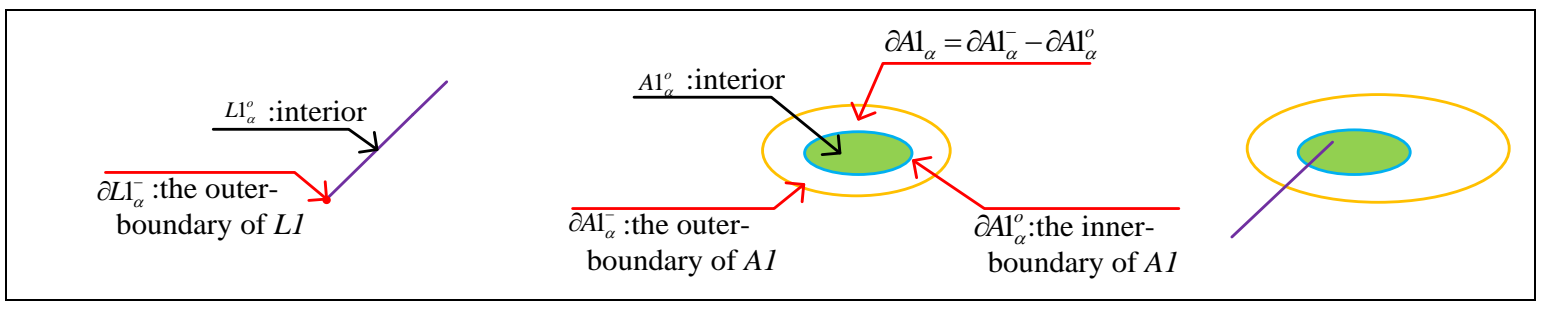

(a)

(b)

(c)

Figure 9: (a) Simple crisp line segment $L 1$; (b) Simple fuzzy region $A 1$ for given $\beta=0.4$; (c) The topological relation between $L 1$ and $A 1$

5) A simple fuzzy line segment $L 1$ for given $\alpha=0.5$ (figure10 (a)), a simple crisp region $A 1$ (figure10 (b)). The topological relation between them was shown in figure10(c). Since the intersection of two sets can be either 0 or 1, the topological relation between $L 1$ and $A l$ can be computed by equation (5) as: $R(L 1, A 1)=\left[\begin{array}{cccc}0 & 0 & 1 & 1 \\ 1 & 1 & 1 & 1\end{array}\right]$.

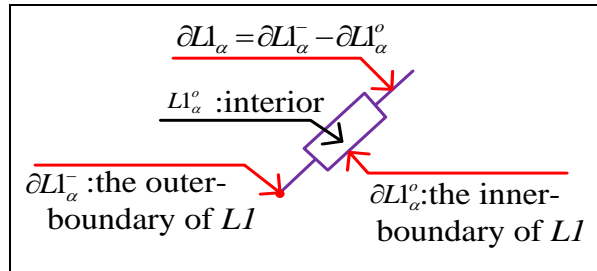

(a)

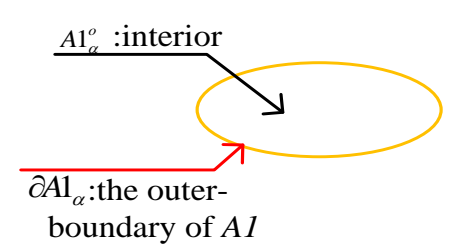

(b)

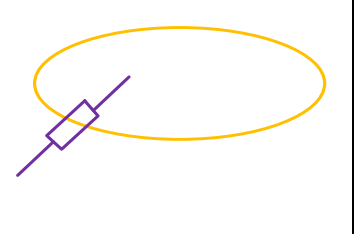

(c)

Figure 10: (a) Simple fuzzy line segment $L 1$ for given $\alpha=0.5$; (b) Simple crisp region Al; (c)

The topological relation between $L 1$ and $A l$ 
6) A simple fuzzy region $A 1$ for given $\alpha=0.5$ (figure11 (a)), a simple fuzzy region $A 2$ for given $\beta$ $=0.3$ (figure11 (b)), the topological relation between them was shown in figure11(c). Since the intersection of two sets can be either 0 or 1, the topological relation between $A 1$ and $A 2$ can be computed by equation (6) as: $R(A 1, A 2)=\left[\begin{array}{llll}1 & 1 & 1 & 1 \\ 1 & 1 & 1 & 1 \\ 1 & 1 & 0 & 0 \\ 1 & 1 & 0 & 0\end{array}\right]$.

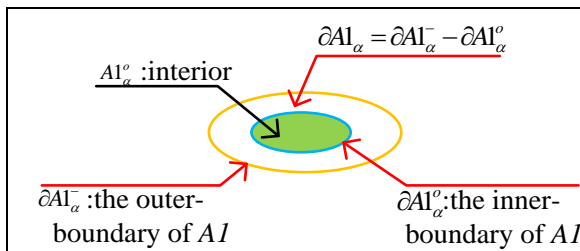

(a)

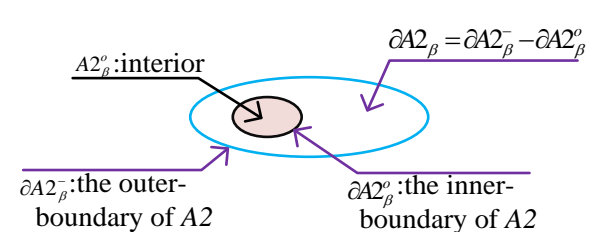

(b)

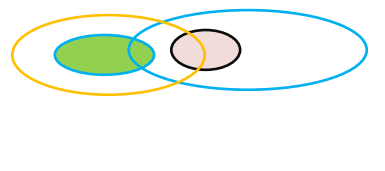

(c)

Figure 11: (a) Simple fuzzyregion $A$ l for given $\alpha=0.5$; (b) Simple fuzzy region $A 2$ for given $\beta$ $=0.3 ;$ (c) The topological relation between $A 1$ and $A 2$

7) A simple fuzzy region $A 1$ for given $\alpha=0.5$ (figure12 (a)), a simple crisp region $A 2$ (figure12 (b)), the topological relation between them was shown in figure12(c). Since the intersection of two sets can be either 0 or 1, the topological relation between $A 1$ and $A 2$ can be computed by equation (7) as: $R(A 1, A 2)=\left[\begin{array}{llll}1 & 1 & 1 & 1 \\ 1 & 1 & 1 & 1\end{array}\right]$.

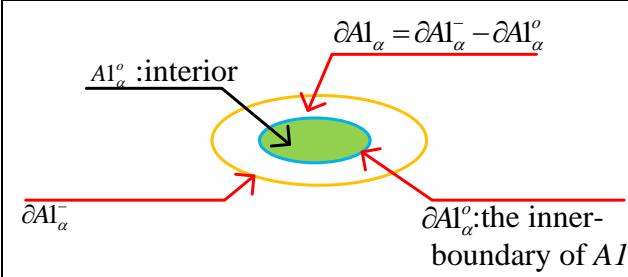

(a)

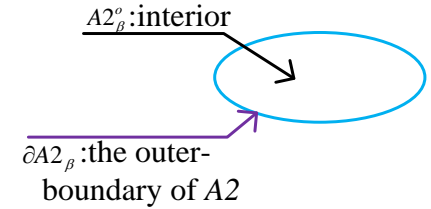

(b)

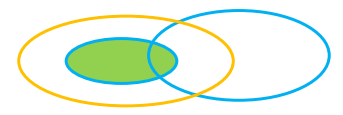

(c)

Figure 12: (a) Simple fuzzyregion $A 1$ for given $\alpha=0.5$; (b) Simple crisp region $A 2$; (c) the topological relation between $A 1$ and $A 2$

\subsection{Comparison with Existing Models}

In dealing with fuzzy spatial objects, Cohn and Gotts (1996) proposed the 'egg-yolk' model with two concentric sub-regions, indicating the degree of 'membership' in a vague/fuzzy region. In this model, the 'yolk' represents the precise part and 'egg' represents the vague/fuzzy part of a region. The 'egg-yolk' model is an extension of RCC theory into the vague/fuzzy region. A total of 46 relations can be identified (Cohn and Gotts, 1996). Based on the 9-intersection model 
$R_{9}(A, B)=\left[\begin{array}{lll}A^{\circ} \cap B^{\circ} & A^{\circ} \cap \partial B & A^{\circ} \cap B^{-} \\ \partial A \cap B^{\circ} & \partial A \cap \partial B & \partial A \cap B^{-} \\ A^{-} \cap B^{\circ} & A^{-} \cap \partial B & A^{-} \cap B^{-}\end{array}\right]$, which was proposed by Egenhofer and Franzosa (1991b),

Clementini and Di Felice defined a region with a broad boundary, by using two simple regions (Clementini and Di Felice, 1996, 1997). This broad boundary is denoted by $\Delta A$. More precisely, a broad boundary is a simple connected subset of $\mathrm{R}^{2}$ with a hole. Based on empty and non-empty invariance, Clementini and Di Felice's Algebraic model, $R_{9}(A, B)=\left[\begin{array}{lll}A^{\circ} \cap B^{\circ} & A^{\circ} \cap \Delta B & A^{\circ} \cap B^{-} \\ \Delta A \cap B^{\circ} & \Delta A \cap \Delta B & \Delta A \cap B^{-} \\ A^{-} \cap B^{\circ} & A^{-} \cap \Delta B & A^{-} \cap B^{-}\end{array}\right]$, gave a total of 44 relations between two spatial regions with a broad boundary.

For example, as shown in figure13(a, b), the extended 9-Intersection model proposed by Clementini and Di Felice $(1996,1997)$ yielded the same matrix, $R_{9}(A, B)=\left[\begin{array}{lll}0 & 1 & 1 \\ 1 & 1 & 1 \\ 0 & 1 & 1\end{array}\right]$, that is to say, the topological relations are same, but they are obviously different from each other as shown in figure13(a, b) . Meanwhile, Liu and Shi (2009) proposed a $3 \times 3$ integration model to compute the topological relations between fuzzy line segments, and discovered sixteen topological relations between simple fuzzy region and simple fuzzy line segment. However, the $3 \times 3$ integration model could not get the topological relation as shown in figure 13(c). Then, we will discuss the topological relation as shown in figure 13 of using the new $4 \times 4$ intersection model (equation (1), (6)) in this paper.

We use the new $4 \times 4$ intersection model to obtain the $4 \times 4$ matrix, as follows:

For figure13 (a), the topological relation matrix is: $R(A 1, A 2)=\left[\begin{array}{cccc}1 & 1 & 1 & 1 \\ 1 & 1 & 1 & 1 \\ 1 & 1 & 0 & 0 \\ 0 & 1 & 0 & 0\end{array}\right]$;

For figure13 (b), the topological relation matrix is: $R(A 1, A 2)=\left[\begin{array}{cccc}1 & 1 & 1 & 1 \\ 1 & 1 & 1 & 1 \\ 0 & 1 & 0 & 0 \\ 0 & 1 & 0 & 0\end{array}\right]$;

For figure13 (c), the topological relation matrix is: $R(L 1, A 1)=\left[\begin{array}{llll}0 & 1 & 0 & 0 \\ 0 & 1 & 1 & 1 \\ 1 & 1 & 0 & 0 \\ 1 & 1 & 0 & 0\end{array}\right]$.

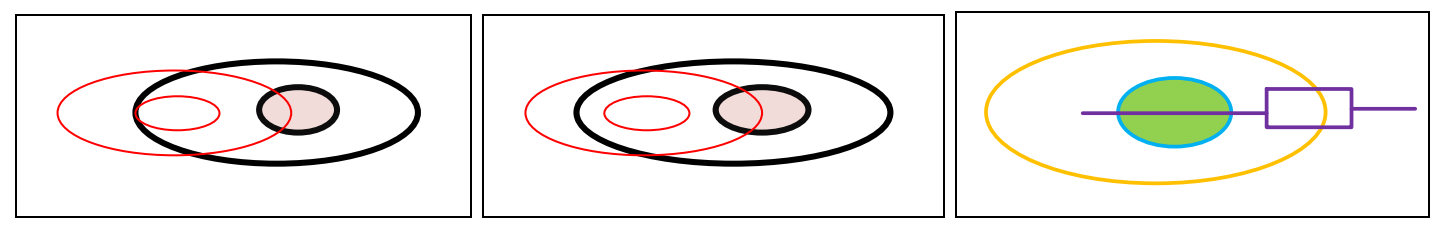

Bol. Ciênc. Geod., sec. Artigos, Curitiba, v. 21, no 2, p.389-408, abr-jun, 2015. 
(a)

(b)

(c)

Figure 13: (a), (b) Two different topological relations between region $A 1$ and $A 2$; (c)

Topological relation between a simple fuzzy line segment $L I$ and a simple fuzzy region $A I$

Through the above comparison analysis, the new proposed model (when taking different values of $\alpha$ and $\beta$ ) not only can compute the topological relations as listed in existing studies (Liu and Shi, 2009; Cohn et al. , 1996, 1997;Clementini and Di Felice,1996,1997), but also the topological relations not currently listed.

\section{CONCLUSION AND DISCUSSION}

Fuzzy topological relations between simple spatial objects can be used for fuzzy spatial queries and spatial analyses. This paper presented a model of fuzzy topological relations for simple spatial objects in GIS. Based on the research of Liu and Shi, we propose a new definition for simple fuzzy line segments and simple fuzzy regions based on the computational fuzzy topology. We also propose a new $4 \times 4$ intersection models to compute the fuzzy topological relations between simple spatial objects, as follows: (1) the topological relations of two simple crisp objects; (2) the topological relations between one simple crisp object and one simple fuzzy object; (3) the topological relations between two simple fuzzy objects. We have discussed some examples to demonstrate the validity of the new model. Through an experiment and comparisons of results, we showed that the proposed method can make finer distinctions, as it is more expressive than the existing fuzzy models.

In this study, fuzzy topology is dependent on the values of $\alpha$ and $\beta$ used in leveling cuts, and different values of $\alpha$ and $\beta$ generate different fuzzy topologies and may have different topological structures. When some applications of fuzzy spatial analyses, an optimal value of $\alpha$ and $\beta$ can be obtained by investigating these fuzzy topologies (Liu and Shi, 2006, Shi and Liu, 2007).

\section{ACKNOWLEDGEMENTS}

The authors would like to thank the Editor and the two anonymous reviewers whose insightful suggestions have significantly improved this letter.

This work was supported by the National Natural Science Foundation of China (No. 41201395, 41161069). Science and Technology Project of Jiangxi Provincial Education Department (No. GJJ14479).

\section{REFERENCES}

Bol. Ciênc. Geod., sec. Artigos, Curitiba, v. 21, no 2, p.389-408, abr-jun, 2015. 
Chang, C.L. "Fuzzy topological spaces." Journal of Mathematical Analysis and Applications, (24), 182-190, 1968.

Clementini, E., Di Felice, D.P. "An algebraic model for spatial objects with indeterminate boundaries." In: Burrough, P.A., Frank, A.U. (Eds.), Geographic Objects with Indeterminate Boundaries. Taylor \& Francis, London and Bristol, 155-169, 1996a.

Clementini, E., Sharma, J., Egenhofer, M.J. "Modeling topological spatial relations: Strategies for query processing." Computers and Graphics, 18(6), 815-822, 1994.

Clementini, E., Di Felice, P. “A model for representing topological relationships between complex geometric features in spatial databases.” Information Sciences, 90(1), 121-136, $1996 \mathrm{~b}$.

Clementini, E., Di Felice, P. “Approximate topological relations.” International Journal of Approximate Reasoning, 16(2), 173-204, 1997.

Clementini, E., Di Felice, P., Koperski, K. "Mining multiplelevel spatial association rules for objects with a broad boundary." Data \& Knowledge Engineering, 34(3), 251-270, 2000.

Cohn, A.G., Gotts, N.M. "The 'egg-yolk' representation of regions with indeterminate boundaries." In: Burrough, P.A., Frank, A.U. (Eds.), Geographic Objects with Indeterminate Boundaries, Taylor \& Francis, London and Bristol, 171-187, 1996.

Cohn, A.G., Bennett, B., Gooday, J., Gotts, N.M. "Qualitative spatial representation and reasoning with the region connection calculus.” GeoInformatica, 1(1), 1-44, 1997.

Dilo, A., de By, R.A., Stein, A. "A system of types and operators for handling vague spatial objects." International Journal of Geographical Information Systems, 21(4), 397-426, 2007.

Du, S.H., Qin, Q.M., Wang, Q., Ma, H. "Evaluating structural and topological consistency of complex regions with broad boundaries in multi-resolution spatial databases." Information Sciences, 178(1), 52-68, 2008a.

Du, S.H., Guo,L., Wang, Q., Qin, Q.M. "Efficiently computing and deriving topological relation matrices between complex regions with broad boundaries." ISPRS Journal of Photogrammetry \& Remote Sensing, (63), 593-609, $2008 \mathrm{~b}$.

Du, S.H., Qin, Q.M., Wang, Q. "Fuzzy description of topological relations I: a unified fuzzy 9intersection model.” In: Wang, L., Chen, K., Ong, Y.S. (Eds.), Advances in Natural Computation, Lecture Notes in Computer Science, 3612, 1260-1273, 2005a.

Du, S.H., Qin, Q.M., Wang, Q. "Fuzzy description of topological relations II: computation methods and examples." In: Wang, L., Chen, K., Ong, Y.S. (Eds.), Advances in Natural Computation, Lecture Notes in Computer Science, 3612, 1274-1279, $2005 \mathrm{~b}$.

Egenhofer, M., Franzosa, R. "Point-set topological spatial relations." International Journal of Geographical Information Systems, 5(2), 161-174, 1991a.

Egenhofer M, Herring J. "Categorizing Binary Topological Relationships between Regions, Lines, Points in Geographic Databases.” Oronoi: Technical Report, Department of Surveying Engineering, University of Maine, Oronoi, ME, $1991 \mathrm{~b}$.

Egenhofer, M., Franzosa, R. "On the equivalence of topological relations." International Journal of Geographical Information Systems, 8(6), 133-152, 1994.

Egenhofer, M., Mark, D. "Modeling Conceptual Neighborhoods of Topological Line-Region Relations.” International Journal of Geographical Information Systems, 9(5), 555-565, 1995. 
Egenhofer, M.J. "Query processing in spatial-query-by-sketch.” Journal of Visual Languages and Computing, 8(4), 403-424, 1997.

Li, C.M., Chen, J., Li, Z.L. "Raster-based method or the generation of Voronoi diagrams for spatial entities.” International Journal of Geographical Information Systems, 13(3), 209, 1999.

Long Z.G, Li S.Q. "A complete classification of spatial relations using the Voronoi-based nineintersection model." International Journal of Geographical Information Science, 27(10), 20062025, 2013.

Liu, K.F., Shi, W.Z. "Computation of fuzzy topological relations of spatial objects based on induced fuzzy topology." International Journal of Geographical Information Systems, 20(8), 857883, 2006.

Liu, K.F., Shi, W.Z. "Quantitative fuzzy topological relations of spatial objects by induced fuzzy topology." International Journal of Applied Earth Observation and Geoinformation, (11), 38-45, 2009.

Liu, K.F., Shi, W.Z., Zhang H. "A fuzzy topology-based maximum likelihood classification." ISPRS Journal of Photogrammetry and Remote Sensing, (66), 103-114, 2011.

Liu, Y.M., Luo, M.K. “Fuzzy Topology.” Singapore: World Scientific, 1997.

Paiva, J.A.C. "Topological equivalence and similarity in multi-representation geographic databases." Ph.D. Dissertation. Department of Surveying Engineering, University of Maine, 1998.

Randell D.A., Cui Z., Cohn A.G. "A spatial logic based on regions and connection." In Proceedings 3rd International Conference on Knowledge Representation and Reasoning, 25-29 October 1992, San Mate, M. Kaufmann, California, 165-176, 1992.

Shi, W.Z., Liu, K.F. "Modelling fuzzy topological relations between uncertain objects in GIS. "Photogrammetric Engineering and Remote Sensing, 70(8), 921-930, 2004.

Shi, W.Z., Liu, K.F. “A fuzzy topology for computing the interior, boundary, and exterior of spatial objects quantitatively in GIS.” Computer and Geoscience, 33(7), 898-915, 2007.

Shi, W.Z., Liu, K.F., Huang C.Q. "A Fuzzy-Topology-Based Area Object Extraction Method.” IEEE Transactions on Geoscience and Remote Sensing, 48(1), 147-154, 2010.

Tang, X.M., Kainz, W. "Analysis of topological relations between fuzzy regions in general fuzzy topological space." In: Proceedings of Spatial Data Handling Conference, Ottawa, Canada, 2002.

Tang, X.M., Kainz, W., Yu F. "Reasoning about changes of land covers with fuzzy settings." International Journal of Remote Sensing, 26(14), 3025-3046, 2005.

Tang, X.M. "Spatial object modeling in fuzzy topological spaces: with applications to land cover change.” Ph.D. Dissertation. University of Twente, 2004.

Winter, S. "Uncertain topological relations between imprecise regions." International Journal of Geographical Information Science, 14(5), 411-430, 2000.

Wong, C.K. "Fuzzy points and local properties of fuzzy topology." Journal of Mathematical Analysis and Applications, (46), 316-328, 1974.

Wu, G., Zheng, C. "Fuzzy boundary and characteristic properties of order homomorphisms." Fuzzy Sets and Systems, (39), 329-337, 1991.

Zadeh, L.A. "Fuzzy Sets.” Information and Control, (8), 338-353, 1965. 
Recebido em Outubro de 2014. Aceito em Março de 2015.

Bol. Ciênc. Geod., sec. Artigos, Curitiba, v. 21, no 2, p.389-408, abr-jun, 2015. 



\title{
ORIENTAÇÃO DE IMAGENS PRISM - ALOS UTILIZANDO DIFERENTES MODELOS DE PLATAFORMA
}

\section{Orientation of PRISM - ALOS images using different platform models}

\author{
Tiago Lima Rodrigues ${ }^{1}$ \\ Edson Aparecido Mitishita ${ }^{2}$ \\ Luiz Danilo Damasceno Ferreira ${ }^{2}$ \\ 1 Universidade Federal Rural do Rio de Janeiro - UFRRJ \\ Instituto de Tecnologia, Departamento de Engenharia \\ BR 465, km 7, 23890-000, Seropédica, RJ, Brasil \\ 2 Universidade Federal do Paraná \\ Curso de Pós-Graduação em Ciências Geodésicas \\ Caixa Postal 515 - 12201-970 - Curitiba - PR, Brasil
}

\section{Resumo:}

Imagens obtidas por sensores de varredura linear orbitais assumem característica dinâmica, uma vez que cada linha obtida pelo CCD apresenta um conjunto de parâmetros de orientação exterior (POE) diferentes. A modelagem matemática da estimativa dos POE para cada instante durante o tempo de formação da imagem tem sido alvo de pesquisas durante as duas últimas décadas. Este trabalho investigou a modelagem a partir da utilização da teoria do Movimento Uniformemente Variado (MUV), associando as acelerações desta às equações de Dinâmica Orbital. Primeiramente foi considerada uma órbita sem perturbações (Movimento Kepleriano) e posteriormente uma órbita com a perturbação proveniente da atração gravitacional terrestre levando em conta a sua elipticidade, representado pelo harmônico zonal de grau 2 (J2), a qual é indicada como uma das mais significativas perturbações. Também foram testados e comparados modelos de plataforma polinomiais. A partir do uso dos diferentes modelos de plataforma foram realizados diversos experimentos com duas imagens PRISM-ALOS. Com base em uma distribuição de pontos de verificação sobre as imagens, as exatidões planimétricas foram calculadas. De forma quase geral, os valores estimados de erro quadrático médio para os pontos de verificação foram muito próximos em termos de GSD (Ground Sample Distance).

Palavras-chave: Orientação exterior, PRISM-ALOS, Harmônico Zonal J2.

\begin{abstract}
:
Images obtained by orbital pushbroom sensor assume linear dynamic characteristic, since each line obtained by the CCD presents a different set of exterior orientation parameters (EOP). The mathematical modeling of the estimate of EOP for each point during the image formation time has been the subject of research over the last two decades. This work investigated the modeling from the use of the theory of Uniformly Accelerated Motion, involving the acceleration of this theory to the equations of Orbital Dynamics, considering an undisturbed orbit (Keplerian motion) and an orbit with the disturbance from Earth's gravitational attraction due to its ellipticity, represented by the zonal harmonic of degree 2 (J2), which is indicated as one of the most significant disturbance. We also tested and compared polynomial models. From the use of different platform models were performed several experiments with two PRISM-ALOS images. Based on a distribution of check
\end{abstract}


points on the images, planimetric accuracies were calculated. Almost general, the estimated values of mean square error for the check points were very close in terms of GSD (Ground Sample Distance).

Keywords: Exterior orientation, PRISM-ALOS, Zonal Harmonic J2.

\section{Introdução}

A utilização de imagens obtidas por plataformas orbitais como fonte de extração de informações espaciais, construção e atualização de documentos cartográficos tem sido cada vez mais explorada. Dentro de um determinado limite de escala, algumas vantagens destas imagens em relação às fotografias aéreas convencionais podem ser evidenciadas, tais como: baixo custo, imageamento de grandes áreas e frequência de aquisição de dados e sensores com resolução espacial cada vez mais finas, abre possibilidades de utilização destes produtos com grande relevância em estudos de diversas áreas do conhecimento.

Neste contexto, as imagens provenientes do satélite japonês ALOS (Advanced Land Observation Satellite), lançado em 24 de janeiro de 2006 e fora de operação desde 21 de abril de 2011, devido a problemas ocorridos nos sistemas de geração de energia, tiveram o objetivo de contribuir para o mapeamento, observação da cobertura da terra, monitoramento de desastres e levantamento de recursos naturais (Japan Aerospace Exploration Agency - JAXA, 2010).

Particularmente para a Cartografia brasileira, as imagens do satélite ALOS foram amplamente utilizadas tanto em instituições públicas, federais, municipais e estaduais, bem como no setor privado. Parte deste resultado é atribuído ao acordo de cooperação entre o Instituto Brasileiro de Geografia e Estatística - IBGE e a Alaska Satellite Facility - ASF, que estabelecia o IBGE como responsável pela distribuição das imagens do sensor PRISM-ALOS para órgãos dos governos federal, estadual e municipal, instituições de pesquisa e demais usuários não comerciais do Brasil, a preços acessíveis. O acordo chegou ao fim em meados do ano de 2011, porém as imagens ainda encontram-se em utilização, sendo comercializadas amplamente no Brasil e no mundo.

Para que haja a possibilidade de extração de informações geodésicas e/ou cartográficas destas imagens é necessária que seja realizada, além da correção radiométrica, a orientação exterior, isto é, a definição das posições do Centro Perspectivo (CP) do sensor e seus ângulos de orientação durante a formação da cena; e a orientação interior do sensor, a qual permite recuperar a geometria de imageamento. Atualmente os modelos matemáticos para orientação de imagens de varredura linear orbitais são definidos de acordo com a complexidade, exatidão e aplicabilidade, em duas classes, a saber (Toutin, 2004): modelos rigorosos, em geral, baseados no princípio da Colinearidade; e modelos ditos generalizados, baseando-se no uso de expressões polinomiais.

Os modelos rigorosos são indicados pela literatura como os que apresentam resultados potencialmente mais acurados (Jacobsen, 2007). Tais modelos objetivam reproduzir o processo físico de formação da cena, levando em conta as informações de geometria interna e externa do sensor e utilizando, em geral, o princípio de colinearidade com pontos. Outra alternativa é o modelo de coplanaridade com retas (Marcato junior e Tommaselli, 2013). Uma vez que estes princípios para sensores de varredura linear são adaptados à natureza dinâmica da formação da cena, deve haver uma preocupação quanto à modelagem das mudanças dos POE durante o processo de geração da cena, ou seja, um modelo matemático que melhor descreva as variações da posição e orientação da plataforma, durante o tempo de aquisição da cena.

Ao efetuar uma análise sobre os modelos que utilizam polinômios de $2^{\circ}$ grau para modelar a órbita, durante o tempo de imageamento, Michalis (2005) associou os termos lineares com a 
velocidade da plataforma e os termos quadráticos com as acelerações. A partir desta consideração, estes mesmos autores desenvolveram um modelo de plataforma denominado Modelo de Kepler, uma vez que as acelerações são estimadas a partir da solução do Problema dos Dois Corpos (Movimento Kepleriano).

No entanto, mesmo um arco de órbita pequeno e bem controlado como as de satélites de Sensoriamento Remoto apresentam influências de diversas perturbações, principalmente a atração devido ao potencial gravitacional terrestre e o arrasto atmosférico (Seeber, 2003). Segundo Light et al. (1980), algumas das causas de distorções em imagens orbitais, relacionadas à plataforma e à Terra são: movimento não elíptico da plataforma (órbita perturbada); influência da gravidade, da forma e do movimento da Terra. Desta forma, tais influências representam erros sistemáticos e devem ser consideradas na propagação dos POE.

Outro ponto também a ser considerado é que no Modelo de Kepler os pontos de apoio e verificação devem estar no Sistema de Coordenadas Geocêntrico Cartesiano Inercial (Michalis, 2005), o que implica em mais uma atividade a ser realizada para o uso deste modelo. Uma forma de contornar esta questão é utilizar o Problema dos Dois Corpos no Sistema de Coordenadas Geocêntrico Cartesiano Terrestre, acrescentando termos em função da velocidade angular de rotação da Terra conforme apresentado em Leick (2004). A desconsideração das componentes de Precessão e Nutação não causam prejuízo neste caso, tendo em vista que o intervalo de obtenção das cenas PRISM/ALOS é relativamente pequeno ( $6 \mathrm{~s})$.

Diante do apresentado, objetiva-se investigar o efeito da inserção de termos adicionais na aceleração proposta por Michalis (2005), no Modelo de Kepler, que representem as perturbações na órbita, bem como a parcela que faça com que o Problema dos Dois Corpos seja utilizado com coordenadas do Sistema de Coordenadas Geocêntrico Cartesiano Terrestre. Considerando que uma das perturbações orbitais mais significativas é a atração gravitacional terrestre devido a sua elipticidade, representada pelo harmônico zonal $\mathrm{J}_{2}$, somente esta pode ser levada em consideração. Outra questão é que, conforme citado, o intervalo de obtenção das cenas é pequeno, e, neste caso, as demais perturbações orbitais não apresentam influências significativas.

Apesar dos testes nesta pesquisa terem sido realizados com cenas PRISM do satélite ALOS, o qual se encontra fora de operação, as metodologias investigadas podem ser aplicadas em outros sensores de varredura linear orbitais e em imagens PRISM que ainda estejam sendo utilizadas.

\section{O Satélite ALOS e o sensor PRISM}

O satélite ALOS foi lançado pela JAXA, em 24 de janeiro de 2006, do centro espacial de Tanegashima (Japão). Sua órbita era circular heliossíncrona com altitude de 691,65 km (do equador) e inclinação de $98,16^{\circ}$. Como objetivos principais tinha-se a geração de dados cartográficos globais, monitoramento de recursos ambientais e naturais mundiais, monitoramento de grandes desastres em escala global e desenvolvimento de tecnologias para o futuro da observação da Terra (JAXA, 2010).

Um dos sensores instalado a bordo do ALOS era o sensor PRISM, composto por três sistemas ópticos independentes, permitindo o imageamento simultâneo nas direções vante (forward), nadir e ré (backward), podendo proporcionar visão estereoscópica e produção de Modelos Digitais de Superfície (MDS). As inclinações nominais das visadas vante e ré em relação ao nadir são de $\pm 23,8$ graus para ter razão base/altura de 1,0. A Figura 1 ilustra a composição do sensor. 


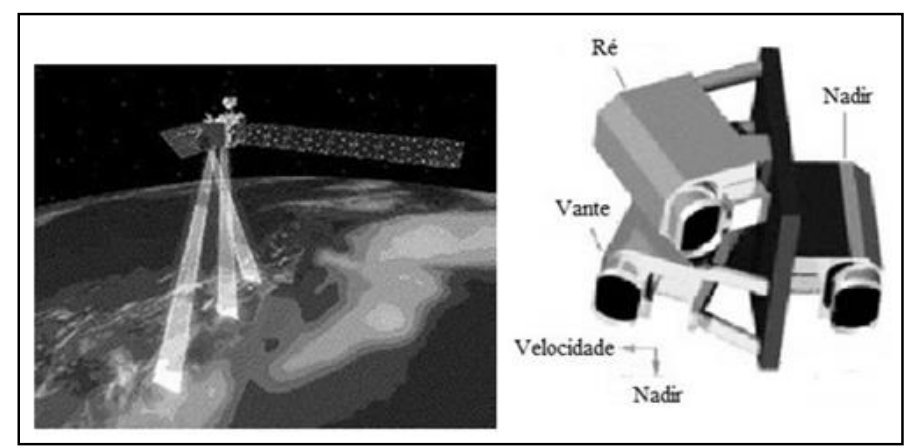

Figura 1: Geometria de funcionamento do sensor PRISM.

Fonte: Adaptado de JAXA (2010).

Algumas principais características do sensor PRISM e alguns dos parâmetros de orientação interior (POI) são apresentados na Tabela 1.

Tabela 1: Características e Parâmetros de orientação interior (POI) do sensor PRISM-ALOS.

\begin{tabular}{c|c}
\hline Características & POI \\
\hline Faixa espectral $0,52-0,77 \mu \mathrm{m}$ & Distância focal 1939 mm \\
\hline Resolução radiométrica $8 \mathrm{bits}$ & $\begin{array}{c}\text { Tamanho do pixel no elemento CCD } \\
0,0071 \mathrm{~mm}\end{array}$ \\
\hline Elementos de resolução espacial $2,5 \mathrm{~m}$ (nadir) & $\mathrm{N}^{\circ}$ de colunas do elemento CCD \\
Largura da faixa imageada & Tempo de integração da linha CCD \\
$70 \mathrm{~km}$ nadir e 35 km no modo tripleto & 0,00037 s/linha \\
\hline
\end{tabular}

As imagens do sensor PRISM são oferecidas com diversos níveis de processamento geométrico/radiométrico, a saber: o nível 1A, 1B1, 1B2-R e o nível 1B2G. Para utilização de modelos rigorosos devem ser utilizados os níveis $1 \mathrm{~A}$ ou 1B1, uma vez que a imagem deve estar sem reamostragem e sem projeção cartográfica que altere as condições geométricas originais de imageamento, a serem modeladas. Mais detalhes sobre os níveis podem ser vistos em JAXA (2010).

\section{Movimento kepleriano e perturbações orbitais}

A equação de movimento de um satélite artificial em torno de uma Terra esférica, sujeito apenas ao campo gravitacional desta é dada a partir da solução do Problema dos Dois Corpos (Bate et al., 1971; Seeber, 2003), no qual o vetor aceleração do satélite é dado por:

$$
\ddot{\vec{r}}=-\frac{G M}{r^{3}} \vec{r},
$$

onde $\ddot{\vec{r}}$ e $\vec{r}$ são respectivamente o vetor aceleração e posição da plataforma no Sistema de Coordenadas Geocêntrico Cartesiano Inercial, $M$ é a massa da Terra e G é a constante gravitacional universal $\left(6,673 \times 10^{-11}\right.$ $\mathrm{m}^{3} / \mathrm{Kg} . \mathrm{s}^{2}$ ), de forma que por exemplo para o sistema de referência WGS84, $G M=3,9860047$ x $10^{14}$ $\mathrm{m}^{3} \mathrm{~s}^{-2}$.

A Equação (1) também é conhecida como Equação do Movimento Kepleriano. Este movimento é considerado como uma primeira aproximação da órbita verdadeira do satélite, uma vez que não considera outras acelerações conhecidas como perturbações orbitais (BATE et al., 1971). Estas acelerações orbitais são forças atuantes de outras naturezas sobre o satélite. 
Rodrigues, T.L et al.

Segundo Seeber (2003), entre os principais efeitos que fazem com que a órbita altere-se com o tempo estão a não esfericidade e não homogeneidade na distribuição da massa da Terra, além do seu achatamento, e também efeitos decorrentes do arrasto atmosférico, pressão de radiação solar e perturbações gravitacionais de outros corpos, notadamente da Lua e do Sol. Devido às estas perturbações, o movimento do satélite fica sujeito a acelerações adicionais. Deste modo, a Equação (1) torna-se (Seeber, 2003):

$$
\ddot{\vec{r}}=-\frac{G M}{r^{3}} \vec{r}+\vec{A}
$$

onde $\vec{A}$ representa "todas" as acelerações perturbadoras que atuam sobre o satélite, ou seja:

$$
\vec{A}=\overrightarrow{A_{G}}+\overrightarrow{A_{S L}}+\overrightarrow{A_{P R}}+\overrightarrow{A_{A L}}+\overrightarrow{A_{M}}+\overrightarrow{A_{A}}
$$

onde $\overrightarrow{A_{G}}$ é aceleração devido à atração gravitacional terrestre; $\overrightarrow{A_{S L}}$ é a aceleração devido à atração gravitacional direta do Sol e da Lua; $\overrightarrow{A_{P R}}$ é a aceleração devido à pressão de radiação solar; $\overrightarrow{A_{A L}}$ é a aceleração devido ao albedo ou pressão de radiação solar indireta; $\overrightarrow{A_{M}}$ é a aceleração devido à atração gravitacional indireta do Sol e da Lua, ou marés e; $\overrightarrow{A_{A}}$ é a aceleração devido ao arrasto atmosférico.

\subsection{Campo gravitacional da Terra}

De acordo com Leick (2004), o vetor aceleração devido ao campo gravitacional da Terra real é dado por:

$$
\overrightarrow{A_{G}}=\left[\begin{array}{lll}
\frac{\partial V}{\partial X_{I}} & \frac{\partial V}{\partial Y_{I}} & \frac{\partial V}{\partial Z_{I}}
\end{array}\right]^{T}
$$

onde $V$ é o potencial gravitacional e $X_{I}, Y_{I}$ e $Z_{I}$ são coordenadas cartesianas geocêntricas inerciais. Uma vez que $V$ é uma função harmônica no exterior das massas planetárias, esta pode ser desenvolvida em uma expansão em série de harmônicos esféricos (Torgue, 2001):

$$
V=\frac{G M}{r}\left[1+\sum_{n=0}^{\infty} \sum_{m=0}^{n}\left(\frac{a_{e}}{r}\right)^{n}\left(C_{n m} \cos m \lambda+S_{n m} \operatorname{sen} m \lambda\right) P_{n m}(\cos \vartheta)\right],
$$

onde $P_{n m}$ é a Função Associada de Legendre, dada por:

com:

$$
P_{n m}(t)=\frac{1}{2^{n} n !}(1+t)^{\frac{m}{2}} \frac{d^{n+m}}{d t^{n+m}}\left(t^{2}-1\right)^{n}
$$

$$
t=\operatorname{sen} \vartheta
$$

onde $C_{n m}$ e $S_{n m}$ são os coeficientes dos harmônicos esféricos do potencial $V$; $a$ é o semi-eixo maior do elipsóide de referência adotado; $\vartheta$ e $\lambda$ são a co-latitude e a longitude geocêntricas, referentes a uma esfera de mesmo volume que o Elipsóide de Referência adotado.

Os coeficientes dos harmônicos esféricos do potencial estão relacionados às deformações que a Terra apresenta em relação a uma Terra perfeitamente esférica (Seeber, 2003). Deste modo, o 
coeficiente $\mathrm{C}_{00}=1$, representa a Terra com distribuição esférica de massa, e, para a origem do Sistema de Coordenadas coincidindo com o centro de massa da Terra, tem-se: $C_{10}=C_{11}=S_{11}=0$ e $\mathrm{S}_{00}=\mathrm{S}_{\mathrm{n} 0}=0$. Deste modo, a Equação (5) torna-se:

$$
V=\frac{G M}{r}\left[1+\sum_{n=2}^{\infty} \sum_{m=0}^{n}\left(\frac{a}{r}\right)^{n}\left(C_{n m} \cos m \lambda+S_{n m} \operatorname{sen} m \lambda\right) P_{n m}(\cos \vartheta)\right]
$$

Segundo Bate et al. (1971), Seeber (2003) e ainda Leick (2004), o coeficiente zonal $\mathrm{C}_{20}=-\mathrm{J}_{2}$ representa o efeito do achatamento da Terra no campo gravitacional, de modo que sua magnitude é aproximadamente 1000 vezes maior que os demais coeficientes dos harmônicos esféricos, o que o torna potencialmente mais significativo na determinação da aceleração devido à atração gravitacional terrestre. Ainda de acordo com Seeber (2003), de longe, a perturbação dominante em satélites de órbitas próximas da Terra é devido ao achatamento da mesma.

Utilizando então $n=2$ e m = 0, a Equação (8) em função de coordenadas cartesianas geocêntricas inerciais torna-se:

$$
V=\frac{G M \cdot a_{e}^{2}}{r^{3}} J_{2}\left(\frac{3}{2} \frac{Z^{2}}{r^{2}}-\frac{1}{2}\right)
$$

de forma que as componentes do vetor aceleração na Equação (4) levando em conta apenas o coeficiente zonal $\mathrm{J}_{2}$ pode ser obtida por:

$$
\begin{aligned}
\ddot{X}_{I} & =-\frac{G M}{r_{I}^{3}} X_{I}-\frac{3}{2} J_{2} \frac{G M a_{e}^{2}}{r_{I}^{5}} X_{I}\left(1-5 \frac{Z_{I}^{2}}{r_{I}^{2}}\right), \\
\ddot{Y}_{I} & =-\frac{G M}{r_{I}^{3}} Y_{I}-\frac{3}{2} J_{2} \frac{G M a_{e}^{2}}{r_{I}^{5}} Y_{I}\left(1-5 \frac{Z_{I}^{2}}{r_{I}^{2}}\right), \\
\ddot{Z}_{I} & =-\frac{G M}{r_{I}{ }^{3}} Z_{I}-\frac{3}{2} J_{2} \frac{G M a_{e}^{2}}{r_{I}^{5}} Z_{I}\left(1-5 \frac{Z_{I}^{2}}{r_{I}^{2}}\right),
\end{aligned}
$$

com:

$$
r_{I}=\sqrt{X_{I}^{2}+Y_{I}^{2}+Z_{I}^{2}}
$$

onde $X_{I}, Y_{I}, Z_{I}$, são as componentes da posição no Sistema de Coordenadas Geocêntrico Cartesiano Inercial. Para se trabalhar com coordenadas no Sistema de Coordenadas Geocêntrico Cartesiano Terrestre, deve-se acrescentar nas Equações (10) termos adicionais em função da velocidade angular de rotação da Terra $\Omega_{\mathrm{t}}$. Desta forma tem-se (Leick, 2004):

com:

$$
\begin{gathered}
\ddot{X}=-\frac{G M}{r^{3}} X-\frac{3}{2} J_{2} \frac{G M a_{e}^{2}}{r^{5}} X\left(1-5 \frac{Z^{2}}{r^{2}}\right)+\Omega_{t}^{2} X+2 \Omega_{t} \dot{Y}, \\
\ddot{Y}=-\frac{G M}{r^{3}} Y-\frac{3}{2} J_{2} \frac{G M a_{e}^{2}}{r^{5}} Y\left(1-5 \frac{Z^{2}}{r^{2}}\right)+\Omega_{t}^{2} Y+2 \Omega_{t} \dot{X}, \\
\ddot{Z}=-\frac{G M}{r^{3}} Z-\frac{3}{2} J_{2} \frac{G M a_{e}{ }^{2}}{r^{5}} Z\left(1-5 \frac{Z^{2}}{r^{2}}\right) .
\end{gathered}
$$

$$
r=\sqrt{X^{2}+Y^{2}+Z^{2}}
$$

onde $X, Y, Z, \dot{X}, \dot{Y}$ e $\dot{Z}$ são respectivamente as componentes de posição e velocidade no Sistema de Coordenadas Geocêntrico Cartesiano Terrestre. 


\section{Orientação de imagens de varredura linear}

Os modelos rigorosos para orientação de imagens geralmente são baseados no princípio de colinearidade ou de coplanaridade, utilizando retas ou pontos. No caso do princípio de colinearidade, tem-se que pontos no espaço imagem, espaço objeto e o $\mathrm{CP}$ da câmera são colineares. Este princípio é modelado através das Equações de Colinearidade, que, no caso de sensores de varredura linear, são modificadas, incluindo a modelagem das mudanças nos POE em função do tempo ou da coordenada $x_{s}$ do Sistema de Coordenadas do sensor (Gugan e Dowman, 1988; Orun e Natarajan, 1994).

Uma vez que cada linha corresponde a uma imagem diferente, a componente $x_{s}$ do espaço imagem é assumida como zero, uma vez que não há deslocamentos nesta direção (Gugan e Dowman, 1988). A Equação de Colinearidade modificada para sensores de varredura linear é apresentada a seguir:

$$
\begin{gathered}
0=x_{\mathrm{s}}=-f \frac{r_{11}\left(X_{i}-X_{S}\right)+r_{12}\left(Y_{i}-Y_{S}\right)+r_{13}\left(Z_{i}-Z_{S}\right)}{r_{31}\left(X_{i}-X_{S}\right)+r_{32}\left(Y_{i}-Y_{S}\right)+r_{33}\left(Z_{i}-Z_{S}\right)}, \\
y_{\mathrm{s}}=-f \frac{r_{21}\left(X_{i}-X_{S}\right)+r_{22}\left(Y_{i}-Y_{S}\right)+r_{23}\left(Z_{i}-Z_{S}\right)}{r_{31}\left(X_{i}-X_{S}\right)+r_{32}\left(Y_{i}-Y_{S}\right)+r_{33}\left(Z_{i}-Z_{S}\right)},
\end{gathered}
$$

sendo $X_{i}, Y_{i}$ e $Z_{i}$ as coordenadas do ponto no espaço objeto; $X_{S}, Y_{S}$ e $Z_{S}$ as coordenadas do CP do sensor no Sistema de Referencia Terrestre (SRT) num dado instante de tomada da linha com o ponto de coordenadas $X_{i}, Y_{i}$ e $Z_{i} ; x_{s}, y_{s}$ são as coordenadas do Sistema de Referência do Sensor (SRS), sendo $x_{S}$ na direção de deslocamento do satélite; $f$ é a distância focal nominal do sensor e; $r_{11}, \ldots, r_{33}$ são os componentes da matriz de rotação. Esta última tem o objetivo de alinhar o Sistema de Coordenadas do espaço imagem com o Sistema de Coordenadas do espaço objeto.

Mesmo partindo do princípio de colinearidade, de uma forma geral, os modelos rigorosos podem ser separados em duas classes, a saber: modelos Posição-Rotação e modelos Órbita-Atitude (Kim e Dowman, 2006).

Nos modelos órbita-atitude, para o alinhamento do sistema de referência do espaço imagem com o sistema de referência do espaço objeto são considerados dois sistemas de referência intermediários. Estes são: o Sistema de Referência da Plataforma (SRP) e o Sistema de Referência Orbital (SRO). Deste modo, são utilizados então o SRS, o SRP, o SRO e o SRT. Uma vez que são considerados todos estes sistemas de referência, os dados de órbita disponibilizados nos arquivos auxiliares das imagens, como posição e velocidade, podem ser utilizados. No caso desta modelagem, os ângulos de atitude da plataforma $(R, P, \Psi)$ apresentam significado físico, pois alinham diretamente o SRP com o SRO. Mais detalhes sobre a estrutura e aplicações deste modelo podem ser vistos em Radhadevi et al. (1994), Kim e Dowman (2006) e Marcato Júnior e Tommaselli (2013).

Os modelos posição-rotação são os modelos primeiramente desenvolvidos e mais utilizados nos aplicativos comerciais. A diferença entre este modelo e o modelo órbita-atitude é que para o alinhamento do sistema de referencia do espaço imagem com o do espaço objeto são considerados apenas o SRS e o SRT. Deste modo, apenas uma matriz de rotação é definida, sendo obtida em função de ângulos de atitude sem significado físico, denominados ômega, phi e kappa $(\omega, \varphi, \kappa)$. Esta característica impede que os dados de órbita provenientes dos metadados das imagens $(R, P$, $\psi)$ sejam utilizados diretamente neste modelo, a não ser que haja a priori a transformação indicada no item anterior. 
Para o caso dos modelos posição-rotação, diversas abordagens distintas foram desenvolvidas para a modelagem das variações dos POE durante a formação da cena. O modelo de plataforma desenvolvido por Gugan e Dowman (1988) apresenta o relacionamento entre os parâmetros de orientação exterior e o tempo $t$ modelado da seguinte forma:

$$
\begin{gathered}
X_{s}=X_{0}+a_{1} t+b_{1} t^{2}, \\
Y_{s}=Y_{0}+a_{2} t+b_{2} t^{2}, \\
Z_{s}=Z_{0}+a_{3} t+b_{3} t^{2}, \\
\omega=\omega_{0}+a_{4} t+b_{4} t^{2}, \\
\varphi=\varphi_{0}+a_{5} t+b_{5} t^{2}, \\
\kappa=\kappa_{0}+a_{6} t+b_{6} t^{2},
\end{gathered}
$$

onde $X_{0}, Y_{0}$ e $Z_{0}$ são as coordenadas do centro perspectivo do sensor na primeira linha da imagem; $a_{1}, a_{2}, \ldots, b_{5}, b_{6}$ são os coeficientes polinomiais da modelagem de mudança nos POE e; $t$ é um dado instante de tempo da formação da cena.

Entretanto, Orun e Natarajan (1994) propuseram um conjunto reduzido partindo das Equações (16), indicando que pequenas variações em $\omega$ tem o mesmo efeito que pequenas variações em $Y_{s}$ e; pequenas variações em $\varphi$ assemelham-se muito à pequenas variações em $X_{s}$. Neste caso, os autores indicaram que há a necessidade de se considerar como constante $\omega$ ou $Y$ e $\varphi$ ou $X$ do conjunto de parâmetros. Considerando que a estimativa da diferença de tempo $(t)$ é função linear da linha da imagem $(L)$, pode-se admitir que $L$ substitui a variação de tempo $t$, e as mudanças em unidades (fator de escala entre $t$ e $L$ ) podem ser absorvidas pelos coeficientes $a$ e $b$. Desta forma, as Equações (16) podem ser reescritas como:

$$
\begin{gathered}
X_{s}=X_{0}+a_{1} L+b_{1} L^{2}, \\
Y_{s}=Y_{0}+a_{2} L+b_{2} L^{2}, \\
Z_{s}=Z_{0}+a_{3} L+b_{3} L^{2}, \\
\kappa=\kappa_{0}+a_{4} L+b_{4} L^{2} .
\end{gathered}
$$

Diferentes configurações de modelos de plataforma em função da linha da imagem, considerando as injunções absolutas ou não em $\omega$ e $\varphi$ podem ser montadas. Exemplos podem ser vistos em Salamonowicz (1986), Gugan e Dowman (1988), Radhadevi et al. (1994), Bang e Cho (2001), Kim e Dowman (2006), Poli (2007), Jeong e Bethel (2008), Weser et al. (2008), Marcato Junior et al. (2011) e Rodrigues e Ferreira (2013).

\subsection{Modelo de Kepler}

Considerando que no caso dos modelos posição-rotação a propagação da posição do satélite, no modelo de plataforma, pode ser modelada a partir de um polinômio de segundo grau, Michalis (2005) apresentou a ideia de que os coeficientes lineares podem representar a velocidade da plataforma e os termos quadráticos as acelerações. 
Rodrigues, T.L et al.

A partir destas considerações, as acelerações utilizadas nos polinômios de segundo grau podem ser calculadas a partir da Equação do Movimento Kepleriano e as equações do modelo da plataforma, associadas a teoria do Movimento uniformemente variado (MUV) são dadas por:

$$
\begin{aligned}
& X_{c}(t)=X_{0}+u_{x} \tau-\frac{G M \cdot X_{0} \cdot \tau^{2}}{2 \cdot\left(X_{0}{ }^{2}+Y_{0}{ }^{2}+Z_{0}{ }^{2}\right)^{3 / 2}}, \\
& Y_{c}(t)=Y_{0}+u_{y} \tau-\frac{G M \cdot Y_{0} \cdot \tau^{2}}{2 \cdot\left(X_{0}{ }^{2}+Y_{0}{ }^{2}+Z_{0}{ }^{2}\right)^{3 / 2}}, \\
& Z_{c}(t)=Z_{0}+u_{z} \tau-\frac{G M \cdot Z_{0} \cdot \tau^{2}}{2 \cdot\left(X_{0}{ }^{2}+Y_{0}{ }^{2}+Z_{0}{ }^{2}\right)^{3 / 2}},
\end{aligned}
$$

onde $u_{x}, u_{y}, u_{y}$ são as componentes do vetor velocidade; $\tau$ é o produto entre $L$ e $d t$ que é o tempo de integração da linha CCD do sensor PRISM (Tabela 1). Para a utilização destes modelos, algumas considerações e indicações são apresentadas conforme descrito em Michalis e Dowman (2008):

- o satélite move-se ao longo de uma órbita bem definida e aproximadamente circular;

- as cenas são adquiridas com um intervalo de tempo constante de aquisição das linhas. Como resultado as coordenadas ao longo do trajeto da plataforma têm a mesma escala;

- a orientação das imagens deve ser realizada em um Sistema de Coordenadas Geocêntrico, a fim de evitar distorções causadas pela curvatura da Terra e da projeção cartográfica e para facilitar a integração com fontes de informações de metadados que podem estar disponíveis;

- o movimento do satélite durante o tempo de aquisição de imagens estéreo alongtrack é considerado um movimento Kepleriano.

Exemplos de aplicação deste modelo podem ser vistos em Dowman e Michalis (2003) utilizando cenas ASTER; Michalis e Dowman (2004), Michalis (2005), Michalis e Dowman (2008a) com cenas HRS-SPOT 5; com cenas do satélite CARTOSAT-I em Michalis e Dowman (2008b); Dowman et al (2010), Michalis e Dowman (2010) em cenas PRISM-ALOS e; em Rodrigues e Ferreira (2013) utilizando cenas HRC-CBERS 2B.

\section{Metodologia}

\subsection{Modelos para a orientação das imagens}

Nesta pesquisa, oito modelos de plataforma foram construídos e analisados. Uma vez que o ângulo $\kappa$ sofre variações devido ao movimento lateral do satélite (crab movement) de acordo com o argumento da latitude da órbita, para compensar o movimento de rotação da Terra (Satoru e Akihiro, 2011), investigou-se a influência de sua variação de forma linear e quadrática. Os ângulos $\omega$ e $\varphi$ foram considerados sem variações por serem bem controlados (acurácia de 1,08”) durante o tempo de formação das cenas (Satoru e Akihiro, 2011).

Para adaptar os modelos que utilizam coordenadas geocêntricas cartesianas inerciais ao uso das coordenadas geocêntricas cartesianas terrestres, as equações dos modelos da plataforma referentes às componentes das posições do satélite foram adaptadas, utilizando-se a teoria apresentada no sub-item 3.1 nas Equações (12) e (13). Nos modelos de 1 a 4 o parâmetro $d t$ utilizado para o cálculo de $\tau$ é considerado constante durante todo o tempo de formação das cenas. 
O modelo 1, denominado aqui de K1 é o modelo de Kepler, considerando os ângulos de atitude $\varphi$ e $\omega$ invariáveis durante o tempo de aquisição das imagens. O ângulo $\kappa$ é considerado variável e propagado com polinômio de $1^{\circ}$ grau. Os ângulos de atitude $\omega$ e $\varphi$, bem como o termo associado à variação do ângulo $\kappa$ são estimados no ajustamento de observações. Tem-se então:

$$
\begin{gathered}
X_{S}(t)=X_{0}+u_{x} t+\left[-\frac{G M \cdot X_{0}}{2 \cdot r^{3}}+\Omega_{t}^{2} X_{0}+2 \Omega_{t} u_{y}\right] \cdot t^{2} \\
Y_{S}(t)=Y_{0}+u_{y} t+\left[-\frac{G M \cdot Y_{0}}{2 \cdot r^{3}}+\Omega_{t}^{2} Y_{0}+2 \Omega_{t} u_{x}\right] \cdot t^{2}, \\
Z_{s}(t)=Z_{0}+u_{z} t-\frac{G M \cdot Z_{0}}{2 \cdot r^{3}} \cdot t^{2}, \\
\omega=\omega_{0}, \\
\varphi=\varphi_{0}, \\
\kappa=\kappa_{0}+d_{1} \cdot t .
\end{gathered}
$$

O modelo 2 foi denominado K2, sendo exatamente o modelo de Kepler, considerando os ângulos de atitude $\varphi$ e $\omega$ invariáveis durante o tempo de aquisição das imagens e $\kappa$ variável. Porém, o que o diferencia do anterior é o fato do ângulo $\kappa$ ser propagado a partir de um polinômio de $2^{\circ}$ grau, ou seja:

$$
\kappa=\kappa_{0}+d_{1} t+d_{2} t^{2}
$$

O Modelo 3 é o modelo de plataforma desenvolvido nesta pesquisa, denominado Modelo de órbita perturbada $\mathrm{J} 2$, e para os experimentos é denominado $\mathrm{J} 2$-1. A posição da plataforma é propagada a partir das Equações de Movimento Kepleriano, adicionando-se as acelerações devido à atração gravitacional terrestre, levando em consideração apenas o coeficiente $\mathbf{J}_{2}$ dos harmônicos esféricos do geopotencial. Nesta primeira configuração, consideram-se os ângulos de atitude $\varphi$ e $\omega$ invariáveis durante o tempo de aquisição das cenas, e o ângulo $\kappa$ é considerado variável e propagado com polinômio de $1^{\circ}$ grau. Os ângulos de atitude e a variação do ângulo $\kappa$ são estimados no processo de ajustamento de observações. O modelo de plataforma assume a forma:

$$
\begin{gathered}
X_{S}(t)=X_{0}+u_{x} t+\left[-\frac{G M}{r^{3}} X_{0}-\frac{3}{2} J_{2} \frac{G M a_{e}^{2}}{r^{5}} X_{0} \cdot\left(1-5 \frac{Z_{0}{ }^{2}}{r^{2}}\right)+\Omega_{t}{ }^{2} X_{0}+2 \Omega_{t} u_{y}\right] \cdot t^{2} \\
Y_{S}(t)=Y_{0}+u_{y} t+\left[-\frac{G M}{r^{3}} Y_{0}-\frac{3}{2} J_{2} \frac{G M a_{e}^{2}}{r^{5}} Y_{0} \cdot\left(1-5 \frac{Z_{0}{ }^{2}}{r^{2}}\right)+\Omega_{t}{ }^{2} Y_{0}+2 \Omega_{t} u_{x}\right] \cdot t^{2} \\
Z_{s}(t)=Z_{0}+u_{z} t+\left[-\frac{G M}{r^{3}} Z_{0}-\frac{3}{2} J_{2} \frac{G M a_{e}^{2}}{r^{5}} Z_{0} \cdot\left(1-5 \frac{Z_{0}{ }^{2}}{r^{2}}\right)\right] \cdot t^{2} \\
\omega=\omega_{0}, \\
\varphi=\varphi_{0}, \\
\kappa=\kappa_{0}+d_{1} \cdot \tau,
\end{gathered}
$$

onde:

$$
r=\sqrt{X_{0}^{2}+Y_{0}^{2}+Z_{0}^{2}}
$$

Uma vez que as imagens estão referenciadas ao ITRF97 (GRS80), os valores das constantes são $G M=3986005 \times 10^{8} \mathrm{~m}^{3} \mathrm{~s}^{-2}, a_{e}=6378137 \mathrm{~m}, \Omega_{t}=7292115 \times 10^{-11} \mathrm{rad} \mathrm{s}^{-1} \mathrm{e} J_{2}=1,08263 \times 10^{-3}$.

O modelo 4 aqui denominado de J2-2, é similar ao modelo 3 , porém considerando que o ângulo $\kappa$ é variável e propagado utilizando-se polinômio de $2^{\circ}$ grau (Equação (20)).

O modelo 5, denominado aqui de ON1, é o modelo proposto por Orun e Natarajan (1994), o qual considera os ângulos de atitude $\omega$ e $\varphi$ invariáveis durante o tempo de aquisição das imagens 
Rodrigues, T.L et al.

(Equações (17)). Estes receberam injunções absolutas, assumindo respectivamente os valores de zero e zero para a câmera nadir, e de zero e $-23,8^{\circ}$ para a câmera ré. Para o modelo 5 , o ângulo $\kappa$ é considerado variável e propagado com polinômio de $1^{\circ}$ grau. $\mathrm{O}$ ângulo $\kappa \mathrm{e}$ o termo associado à sua variação são estimados no ajustamento de observações.

O sexto modelo analisado (ON2) é o quinto modelo, porém considerando a variação do ângulo $\kappa$ de forma quadrática, ou seja:

$$
\kappa=\kappa_{0}+a_{4} L+b_{4} L^{2}
$$

O Modelo 7 (P1), considera a modelagem polinomial da trajetória, assim como o modelo proposto por Orun e Natarajan (1994), porém, o que o diferenciou deste último é a não aplicação das injunções absolutas nos ângulos $\varphi$ e $\omega$, ou seja, estes são estimados no ajustamento. Similarmente aos demais modelos, estes dois ângulos foram considerados invariáveis durante o tempo de aquisição das imagens. Neste modelo, o ângulo $\kappa$ é considerado variável e propagado com polinômio de $1^{\circ}$ grau.

O oitavo modelo testado (P2) é o sétimo modelo, porém considerando a variação do ângulo $\kappa$ de forma quadrática (Equação (20)).

O Sistema de Coordenadas do espaço objeto no caso dos modelos ON1, ON2, P1 e P2 foi o Sistema Geodésico Local, adotando como origem em cada cena a média das coordenadas dos pontos de apoio distribuídas sobre a mesma.

Para a estimativa dos parâmetros nos oito modelos, utilizou-se o Método dos Mínimos Quadrados com o método paramétrico (Gemael, 1994), tendo em vista que as equações dos modelos de orientação utilizados foram organizadas de maneira a isolar as observações como função dos parâmetros de forma explícita. Os parâmetros estimados nos ajustamentos em cada modelo são indicados na Tabela 2 a seguir.

Tabela 2: Parâmetros a serem estimados no ajustamento.

\begin{tabular}{c|c}
\hline $\begin{array}{c}\text { Modelo de } \\
\text { Plataforma }\end{array}$ & Parâmetros \\
\hline K1 e J2-1 & $X_{0}, Y_{0}, Z_{0}, u_{x}, u_{y}, u_{z}, \omega, \varphi, \kappa, d_{1}$. \\
\hline K2 e J2-2 & $X_{0}, Y_{0}, Z_{0}, u_{x}, u_{y}, u_{z}, \omega, \varphi, \kappa, d_{1}, d_{2}$. \\
\hline ON1 & $X_{0}, a_{1}, b_{1}, Y_{0}, a_{2}, b_{2}, Z_{0}, a_{3}, b_{3}, \kappa, a_{4}$. \\
\hline ON2 & $X_{0}, a_{1}, b_{1}, Y_{0}, a_{2}, b_{2}, Z_{0}, a_{3}, b_{3}, \kappa, a_{4}, b_{4}$. \\
\hline $\mathrm{P} 1$ & $X_{0}, a_{1}, b_{1}, Y_{0}, a_{2}, b_{2}, Z_{0}, a_{3}, b_{3}, \omega, \varphi, \kappa, a_{4}$ \\
\hline $\mathrm{P} 2$ & $X_{0}, a_{1}, b_{1}, Y_{0}, a_{2}, b_{2}, Z_{0}, a_{3}, b_{3}, \omega, \varphi, \kappa, a_{4}, b_{4}$. \\
\hline
\end{tabular}

\subsection{Estudos de caso}

Nesta pesquisa foram utilizadas duas imagens (15046/4100 e 15046/4045) pertencentes a um tripleto PRISM, de 20/11/2008, em nível de processamento 1B1. Estas imagens foram cedidas pelo Departamento de Cartografia da Faculdade de Ciências e Tecnologia da Universidade Estadual Paulista. A área de aproximadamente 35 x $35 \mathrm{~km}$ coberta por cada imagem abrange o município de Presidente Prudente - SP e região.

As coordenadas terrestres utilizadas, tanto no processo de orientação quanto no processo de 
verificação de acurácias, foram obtidas por (Toledo et al., 2010) a partir de rastreios com receptores GNSS (Global Navigation Satellite System), utilizando o método de posicionamento relativo estático com tempo de rastreio de, no mínimo, 30 minutos. Isto com a finalidade de atingir um erro menor que $0,5 \mathrm{~m}$, que corresponde a, aproximadamente, um terço do GSD (Ground Sample Distance). O processamento dos dados foi realizado com efemérides precisas no software TGO (Trimble Geometics Office).

Dois grupos de experimentos foram definidos baseados em diferentes quantidades de pontos de apoio e verificação. No primeiro grupo foram selecionados 14 pontos de apoio (PA) e 9 pontos de verificação (PV), sendo que em decorrências das duas cenas recobrirem quase o mesmo local, os pontos foram os mesmos paras ambas. No segundo grupo, as configurações foram invertidas, ou seja, 9 pontos de apoio (PA) e 14 de verificação. A Figura 2 apresenta a distribuição dos pontos de apoio e verificação nas duas cenas utilizadas nos dois grupos de experimentos. No espaço imagem, os pontos foram observados no aplicativo ERDAS/LPS 2010 de modo manual. Na pesquisa, a precisão considerada na medição foi de 1 pixel.

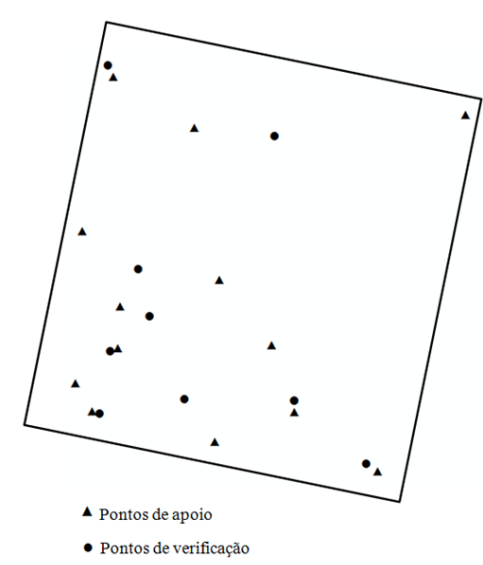

(a)

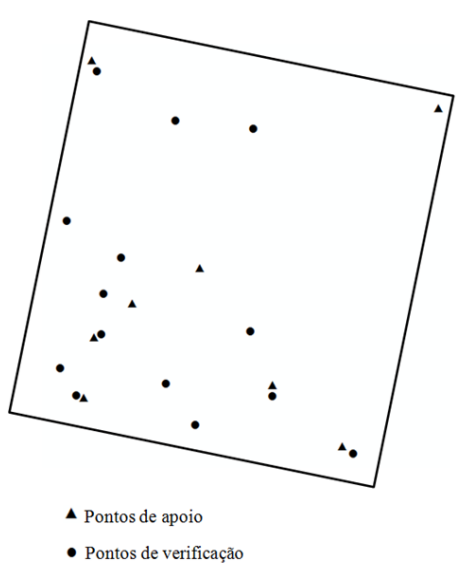

(b)

Figura 2: Distribuição dos pontos de apoio e verificação nas cenas do primeiro grupo de experimentos (a) e do segundo grupo de experimentos (b).

\section{Resultados}

\subsection{Resultados obtidos com a imagem em visada Ré}

Estes resultados referem-se à aplicação dos modelos apresentados no item 5.1 na orientação da imagem em visada ré, utilizando as duas configurações de pontos de apoio e verificação, sendo denominados experimentos de 1 a 16 respectivamente, conforme indicado na Tabela 3 a seguir. Após o ajustamento das observações, a partir dos pontos de apoio selecionados no espaço objeto utilizando cada um dos modelos, foi possível estimar os POE das imagens e suas respectivas precisões a partir das Matrizes Variância-Covariância (MVCs). Em todos os experimentos, em ambos os casos de distribuição de pontos de apoio, as precisões dos POE apresentaram comportamento semelhante com relação às ordens de grandeza. $\mathrm{O}$ valor mais alto de precisão chegou a no máximo duas ordens de grandeza a menos do que o valor do seu respectivo parâmetro. 
Tabela 3: Experimentos para a imagem em visada ré.

\begin{tabular}{|c|c|c|c|}
\hline \multicolumn{2}{|c|}{ Configuração de pontos de apoio 1} & \multicolumn{2}{|c|}{ Configuração de pontos de apoio 2} \\
\hline Experimento & Modelo & Experimento & Modelo \\
\hline 1 & K1 & 9 & K1 \\
\hline 2 & $\mathrm{~K} 2$ & 10 & $\mathrm{~K} 2$ \\
\hline 3 & $\mathrm{~J} 2-1$ & 11 & $\mathrm{~J} 2-1$ \\
\hline 4 & $\mathrm{~J} 2-2$ & 12 & $\mathrm{~J} 2-2$ \\
\hline 5 & ON1 & 13 & ON1 \\
\hline 6 & ON2 & 14 & ON2 \\
\hline 7 & P1 & 15 & P1 \\
\hline 8 & P2 & 16 & P2 \\
\hline
\end{tabular}

Como anteriormente citado, o ângulo $\kappa$ sofre variações devido ao movimento lateral do satélite (crab movement), e, conforme indicado no item 3.2, foram verificadas variações lineares e quadráticas. Com relação à variação linear, para os experimentos 1, 3, 9 e 11, os valores foram em média de aproximadamente 30\%/s. Neste caso, a não consideração desta pode acarretar em pequenos deslocamentos nas coordenadas do espaço objeto ao longo da cena. Com relação à variação quadrática, para os experimentos $2,4,10$ e 12, em média os valores ficaram em torno de alguns centésimos de " $/ s$, não sendo capaz de proporcionar deslocamentos significativos das cenas no caso de sua desconsideração. Esta afirmação pode ser comprovada a partir da Tabela 7 das raízes dos erros médios quadráticos (RMSE) dos pontos de verificação. Para os experimentos 5, 6, 13 e 14, tanto as variações lineares quanto as quadráticas apresentaram-se na ordem de grandeza de milésimos de "/linha. Para os experimentos 7, 8, 15 e 16, as variações lineares apresentaram-se na ordem de grandeza de milésimos de "/linha, e as variações quadráticas de $10^{-7}$ a $10^{-8}$ " /linha. De forma geral, as variações quadráticas de $\kappa$ não modificaram de forma significativa a acurácia das orientações, conforme pode ser visto mais adiante nos valores de RMSE dos pontos de verificação.

Outro grupo de resultados analisados foi o proveniente dos ajustamentos de observações, como o teste do Qui-quadrado para análise das variâncias a priori e posteriori, e os RMSE dos vetores dos resíduos (Tabela 4).

Tabela 4: Resultados obtidos nos ajustamentos para os experimentos da imagem em visada ré com a distribuição de pontos 1 e 2 .

\begin{tabular}{|c|c|c|c|}
\hline $\begin{array}{c}\text { Exp. (MP) com } \\
\text { distribuição de pontos } 1 \\
\end{array}$ & Resultados & $\begin{array}{c}\text { Exp. (MP) com } \\
\text { distribuição de pontos } 2 \\
\end{array}$ & Resultados \\
\hline $1(\mathrm{~K} 1)$ & $\begin{array}{c}\chi_{\text {calculado: }}^{2}: 12,0894 \\
\chi_{\text {teórico }}^{2}(18 ; 0,975): 31,53 \\
\operatorname{RMSE} x_{s}: 0,0049 \mathrm{~mm} \\
\operatorname{RMSEE} y_{s}: 0,0048 \mathrm{~mm}\end{array}$ & $9(\mathrm{~K} 1)$ & $\begin{array}{c}\chi_{\text {calculado: }}^{2} 9,0213 \\
\chi_{\text {teórico }}(8 ; 0,975): 17.53 \\
\text { RMSE } x_{s}: 0,0073 \mathrm{~mm} \\
\text { RMSE } y_{s}: 0,0019 \mathrm{~mm}\end{array}$ \\
\hline $2(\mathrm{~K} 2)$ & $\begin{array}{c}\chi_{\text {calculado: }}^{2} 11,6850 \\
\chi_{\text {teórico }}^{2}(17 ; 0,975): 30,19 \\
\operatorname{RMSE} x_{s}: 0,0051 \mathrm{~mm} \\
\operatorname{RMSEE} y_{s}: 0,0044 \mathrm{~mm}\end{array}$ & $10(\mathrm{~K} 2)$ & $\begin{array}{c}\chi_{\text {calculado: }}^{2} 9,0050 \\
\chi_{\text {teórico }}(7 ; 0,975): 16.01 \\
\text { RMSE } x_{s}: 0,0072 \mathrm{~mm} \\
\text { RMSE } y_{s}: 0,0021 \mathrm{~mm}\end{array}$ \\
\hline $3(\mathrm{~J} 2-1)$ & $\begin{array}{c}\chi_{\text {calculado: }}^{2} 9,2805 \\
\chi_{\text {térico }}^{2}(18 ; 0,975): 31,53 \\
\operatorname{RMSE} x_{s}: 0,0041 \mathrm{~mm} \\
\operatorname{RMSEE} y_{s}: 0,0044 \mathrm{~mm}\end{array}$ & $11(\mathrm{~J} 2-1)$ & $\begin{array}{c}\chi_{\text {calculado }}^{2}: 10,7892 \\
\chi_{\text {teórico }}^{\text {2 }}(8 ; 0,975): 17.53 \\
\text { RMSE } x_{s}: 0,0079 \mathrm{~mm} \\
\text { RMSE } y_{s}: 0,0024 \mathrm{~mm}\end{array}$ \\
\hline
\end{tabular}




\begin{tabular}{|c|c|c|c|}
\hline $4(\mathrm{~J} 2-2)$ & $\begin{array}{c}\chi_{\text {calculado }}^{2}: 9,1444 \\
\chi_{\text {teórico }}^{2}(17 ; 0,975): 30,19 \\
\text { RMSE } x_{s}: 0,0041 \mathrm{~mm} \\
\operatorname{RMSE~} y_{s}: 0,0043 \mathrm{~mm}\end{array}$ & $12(\mathrm{~J} 2-2)$ & $\begin{array}{c}\chi_{\text {calculado: }}^{2}: 10,7891 \\
\chi_{\text {teórico }}^{2}(7 ; 0,975): 16.01 \\
\text { RMSE } x_{s}: 0,0079 \mathrm{~mm} \\
\operatorname{RMSE} y_{s}: 0,0025 \mathrm{~mm}\end{array}$ \\
\hline $5(\mathrm{ON} 1)$ & $\begin{array}{c}\chi_{\text {calculado: }}^{2} 14.1930 \\
\chi_{\text {teórico }}^{2}(17 ; 0,975): 30,19 \\
\operatorname{RMSE} x_{s}: 0,0045 \mathrm{~mm} \\
\operatorname{RMSE} y_{s}: 0,0059 \mathrm{~mm}\end{array}$ & 13 (ON1) & $\begin{array}{c}\chi_{\text {calculado: }}^{2} 61,4200 \\
\chi_{\text {teórico }}^{2}(7 ; 0,975): 16.01 \\
\operatorname{RMSE} x_{s}: 0,0195 \mathrm{~mm} \\
\operatorname{RMSE} y_{s}: 0,0028 \mathrm{~mm}\end{array}$ \\
\hline $6(\mathrm{ON} 2)$ & $\begin{array}{c}\chi_{\text {calculado }}^{2}: 14,1468 \\
\chi_{\text {teórico }}^{2}(16 ; 0,975): 28,85 \\
\text { RMSE } x_{s}: 0,0044 \mathrm{~mm} \\
\operatorname{RMSE} y_{s}: 0,0059 \mathrm{~mm}\end{array}$ & 14 (ON2) & $\begin{array}{c}\chi_{\text {calculado: }}^{2} 61,2716 \\
\chi_{\text {teórico }}^{2}(6 ; 0,975): 14.45 \\
\operatorname{RMSE} x_{s}: 0,0195 \mathrm{~mm} \\
\operatorname{RMSE} y_{s}: 0,0028 \mathrm{~mm}\end{array}$ \\
\hline 7 (P1) & $\begin{array}{c}\chi_{\text {calculado }}^{2}: 7,5052 \\
\chi_{\text {teórico }}^{2}(15 ; 0,975): 27,49 \\
\text { RMSE } x_{s}: 0,0041 \mathrm{~mm} \\
\operatorname{RMSE} y_{s}: 0,0035 \mathrm{~mm}\end{array}$ & $15(\mathrm{P} 1)$ & $\begin{array}{c}\chi_{\text {calculado }}^{2}: 6,9935 \\
\chi_{\text {teórico }}^{2}(5 ; 0,975): 12.83 \\
\text { RMSE } x_{s}: 0,0066 \mathrm{~mm} \\
\text { RMSE } y_{s}: 0,0005 \mathrm{~mm}\end{array}$ \\
\hline $8(\mathrm{P} 2)$ & $\begin{array}{c}\chi_{\text {calculado }}^{2}: 7,4527 \\
\chi_{\text {teórico }}^{2}(14 ; 0,975): 26,12 \\
\text { RMSE } x_{s}: 0,0041 \mathrm{~mm} \\
\operatorname{RMSE} y_{s}: 0,0035 \mathrm{~mm}\end{array}$ & $16(\mathrm{P} 2)$ & $\begin{array}{c}\chi_{\text {calculado: }}^{2} 0,1802 \\
\chi_{\text {teórico }}^{2}(4 ; 0,975): 11,1433 \\
\operatorname{RMSE} x_{s}: 0,0009 \mathrm{~mm} \\
\operatorname{RMSE~} y_{s}: 0,0005 \mathrm{~mm}\end{array}$ \\
\hline
\end{tabular}

Observa-se na Tabela 4 que com exceção dos experimentos 13 e 14, a hipótese básica de $\hat{\sigma}_{0}^{2}=\sigma_{0}^{2}$ (com $\sigma_{0}^{2}=1$ ) não é rejeitada ao nível de significância de $5 \%$ no teste do Qui-quadrado. Nos resultados dos experimentos de 1 a 12 e de 15 e 16, as ordens de grandeza dos componentes dos vetores dos resíduos em $x_{s}$ e $y_{s}$ apresentaram-se adequadas, na maioria das vezes apresentando valores abaixo do pixel e na minoria das vezes chegando a apresentar valores em torno de 1 pixel. Nos experimentos 13 e 14 os valores dos resíduos foram mais elevados (apenas na componente $x_{s}$ ) em relação aos demais experimentos, chegando na grande maioria dos pontos a valores maiores do que 1 pixel, com valor máximo de $0,0371 \mathrm{~mm}$. Este fato levou à rejeição da hipótese básica no teste do Qui-quadrado. Isto pode ter sido causado por erros sistemáticos decorrentes da aplicação das injunções absolutas nos ângulos $\omega$ e $\varphi$, tendo em vista que nos experimentos 15 e 16, onde tais ângulos foram estimados nos ajustamentos, não houveram valores elevados de resíduo.

Embora a magnitude dos valores das componentes do vetor dos resíduos tenham sido diferentes, em todos os experimentos as médias dos mesmos foram próximas de zero ( $10^{-6}$ no máximo). Exceto para os experimentos 13 e 14 pode-se indicar que, considerando os testes na imagem em visada ré, os modelos matemáticos conseguiram representar satisfatoriamente a realidade física do processo.

Posteriormente à estimativa dos parâmetros e aplicação dos mesmos no modelo de Colinearidade inverso, a avaliação da acurácia das orientações foi realizada. Nas Equações de Colinearidade inversa, para o valor de $Z_{i}$ foram utilizados os valores dos próprios pontos de verificação. Neste processo, as coordenadas dos pontos de verificação, foram transformadas de coordenadas planoretanguares do sistema UTM $(\mathrm{E}, \mathrm{N})$ para coordenadas do Sistema Geodésico Local $\left(\mathrm{X}_{\mathrm{L}}, \mathrm{Y}_{\mathrm{L}}\right)$, uma vez que este Sistema de Coordenadas permite uma representação mais fiel da situação dos 
Rodrigues, T.L et al.

deslocamentos na superfície terrestre. A Tabela 5 a seguir apresenta a acurácia nas componentes $\mathrm{X}_{\mathrm{L}}$ e $\mathrm{Y}_{\mathrm{L}}$ em todos os modelos analisados na imagem em visada ré.

Tabela 5: Acurácia nas componentes $X_{L}, Y_{L}$ para os pontos de verificação nos experimentos da imagem em visada ré.

\begin{tabular}{|c|c|c|c|c|c|}
\hline \multirow{3}{*}{$\begin{array}{c}\begin{array}{c}\text { Exp. (Modelo) com } \\
\text { distribuição de pontos } 1\end{array} \\
1(\mathrm{~K} 1)\end{array}$} & \multicolumn{2}{|c|}{ RMSE (m) } & \multirow{3}{*}{$\begin{array}{c}\begin{array}{c}\text { Exp. (Modelo) com } \\
\text { distribuição de pontos } 2\end{array} \\
9(\mathrm{~K} 1)\end{array}$} & \multicolumn{2}{|c|}{ RMSE (m) } \\
\hline & \multicolumn{2}{|c|}{$\mathbf{X}_{\mathrm{L}} \quad \mathbf{Y}_{\mathrm{L}}$} & & & $\mathbf{Y}_{\mathbf{L}}$ \\
\hline & 1,961 & 1,468 & & 1,712 & 2,764 \\
\hline $2(\mathrm{~K} 2)$ & 1,948 & 1,502 & $10(\mathrm{~K} 2)$ & 1,718 & 2,725 \\
\hline $3(\mathrm{~J} 2-1)$ & 1,957 & 1,101 & $11(\mathrm{~J} 2-1)$ & 1,854 & 2,860 \\
\hline $4(\mathrm{~J} 2-2)$ & 1,990 & 1,116 & $12(\mathrm{~J} 2-2)$ & 1,862 & 2,856 \\
\hline 5 (ON1) & 2,714 & 2,442 & $13(\mathrm{ON} 1)$ & 2,495 & 16,190 \\
\hline $6(\mathrm{ON} 2)$ & 2,711 & 2,386 & $14(\mathrm{ON} 2)$ & 2,468 & 16,051 \\
\hline 7 (P1) & 1,834 & 2,350 & $15(\mathrm{P} 1)$ & 5,158 & 3,871 \\
\hline $8(\mathrm{P} 2)$ & 1,827 & 2,452 & $16(\mathrm{P} 2)$ & 5,124 & 4,666 \\
\hline
\end{tabular}

A partir da análise dos valores da Tabela 5 observa-se inicialmente que a consideração da variação quadrática do ângulo $\kappa$ não influenciou de maneira significativa na qualidade das orientações, apresentando-se por vezes ligeiramente melhor ou pior. Observa-se também que a adaptação dos modelos de plataforma nos experimentos de 1 a 4 e de 9 a 12 ao uso das coordenadas referenciadas ao Sistema de Coordenadas Geocêntricas Cartesianas Terrestres, apresentou-se eficaz, tendo em vista que os valores de RMSE alcançaram valores de em torno de 1 pixel ou menor. Em relação à inserção do termo que modela a perturbação orbital do satélite, proveniente da atração gravitacional terrestre devido a sua elipticidade, representada pelo harmônico zonal $\mathbf{J}_{2}$, tem-se que esta não alterou significativamente as acurácias das orientações, também se apresentando por vezes pouco melhor ou pior em reação aos demais modelos. Percebe-se ainda com os resultados da Tabela 5 que para o caso da imagem em visada ré houve uma menor flexibilidade de quantidade e distribuição de pontos de apoio nos modelos polinomiais com relação aos resultados de acurácia, e, que de forma geral, os experimentos que utilizaram os modelos ON1 e ON2 apresentaram piores resultados do que os experimentos utilizando os modelos P1 e P2. Um indicativo de tais resultados é a aplicação das injunções absolutas nos ângulos $\omega$ e $\varphi$ ao invés de estimá-los como parâmetros nos ajustamentos. Por fim, tem-se que os modelos K1, K2, J2-1 e J2-2 apresentaram-se próximos e com resultados ligeiramente melhores do que os modelos P1 e P2 na primeira distribuição de pontos de apoio. Já na segunda distribuição, a melhora foi mais significativa, atingindo diferenças métricas. Tal fato pode ser visualizado quando se efetua o cálculo dos deslocamentos planimétricos resultantes, conforme apresentado graficamente na Figura 3 a seguir. Em síntese, a utilização de modelos de plataforma polinomiais, com variação linear ou quadrática de $\kappa$, como já esperado, é mais influenciado pela distribuição e número de pontos de apoio na cena, do que os modelos que utilizaram a Equação de Movimento do satélite para modelagem da órbita.

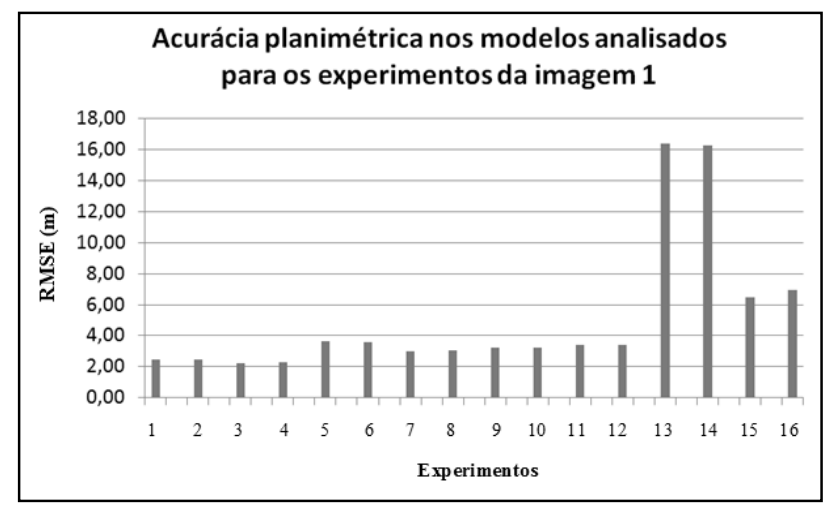

Figura 3: RMSE nos modelos analisados na imagem em visada ré. 
Com o objetivo de verificar se houveram tendências nos experimentos, testes de hipótese de tendência, utilizando a distribuição $t$ de student, com nível de confiança de $95 \%$ foram realizados. As hipóteses testadas foram H0: $\mu=0$ e H1: $\mu \neq 0$. O valor de $t$ amostral calculado é dado por:

$$
t=\frac{\mu-\mu_{0}}{s} \sqrt{n}
$$

onde $\mu$ é a média amostral, $\mu_{0}$ é a média populacional esperada (assumida como 0 - sem tendência), $s$ é o desvio padrão amostral e $n$ é o número de pontos de verificação. Na Tabela 6 são apresentados os resultados.

Tabela 6: Testes de tendência para os experimentos da imagem em visada ré.

\begin{tabular}{c|c|c|c|c|c|c|c}
\hline Exp. (MP) & $\begin{array}{c}\text { t calc./ } \\
\text { Comp. } \mathbf{X}_{\mathbf{L}}\end{array}$ & $\begin{array}{c}\mathbf{t} \text { calc./ } \\
\text { Comp. } \mathbf{Y}_{\mathbf{L}}\end{array}$ & $\mathbf{t}$ (gl;0,975) & Exp. (MP) & $\begin{array}{c}\text { t calc./ } \\
\text { Comp. } \mathbf{X}_{\mathbf{L}}\end{array}$ & $\begin{array}{c}\mathbf{t} \text { calc./ } \\
\text { Comp. } \mathbf{Y}_{\mathbf{L}}\end{array}$ & $\mathbf{t}$ (gl;0,975) \\
\hline $1(\mathrm{~K} 1)$ & 2,203 & 1,077 & 2,306 & $9(\mathrm{~K} 1)$ & 1,568 & 1,709 & 2,1604 \\
\hline $2(\mathrm{~K} 2)$ & 1,802 & 1,076 & 2,306 & $10(\mathrm{~K} 2)$ & 1,554 & 1,719 & 2,1604 \\
\hline $3(\mathrm{~J} 2-1)$ & 1,908 & 1,256 & 2,306 & $11(\mathrm{~J} 2-1)$ & 1,265 & 1,694 & 2,1604 \\
\hline $4(\mathrm{~J} 2-2)$ & 1,587 & 1,250 & 2,306 & $12(\mathrm{~J} 2-2)$ & 1,251 & 1,694 & 2,1604 \\
\hline $5(\mathrm{ON} 1)$ & 1,703 & 1,312 & 2,306 & $13(\mathrm{ON} 1)$ & 1,097 & 1,098 & 2,1604 \\
\hline $6(\mathrm{ON} 2)$ & 1,675 & 1,394 & 2,306 & $14(\mathrm{ON} 2)$ & 1,115 & 1,116 & 2,1604 \\
\hline $7(\mathrm{P} 1)$ & 2,018 & 1,295 & 2,306 & $15(\mathrm{P} 1)$ & 1,021 & 1,482 & 2,1604 \\
\hline $8(\mathrm{P} 2)$ & 1,990 & 1,209 & 2,306 & $16(\mathrm{P} 2)$ & 0,913 & 1,395 & 2,1604 \\
\hline
\end{tabular}

A partir da análise da Tabela 6 nota-se que nenhum experimento apresentou tendência significativa ao nível de confiança de $95 \%$ para ambas as componentes $\mathrm{X}_{\mathrm{L}}$ e $\mathrm{Y}_{\mathrm{L}}$.

\subsection{Resultados obtidos com a imagem em visada Nadir}

Estes resultados referem-se à aplicação dos modelos apresentados no item 5.1 na orientação da imagem em visada nadir, utilizando as duas configurações de pontos de apoio e verificação, sendo denominados experimentos de 17 a 32 respectivamente, conforme indicado na Tabela 7 a seguir.

Tabela 7: Experimentos para a imagem em visada nadir.

\begin{tabular}{cc|cc}
\hline \multicolumn{2}{c|}{ Configuração de pontos de apoio 1 } & \multicolumn{2}{c}{ Configuração de pontos de apoio 2 } \\
\hline \multicolumn{2}{c|}{ Experimento } & Modelo & \multicolumn{2}{c}{ Experimento } & Modelo \\
\hline 17 & K1 & 25 & K1 \\
\hline 18 & K2 & 26 & K2 \\
\hline 19 & J2-1 & 27 & J2-1 \\
\hline 20 & J2-2 & 28 & J2-2 \\
\hline 21 & ON1 & 29 & ON1 \\
\hline 22 & ON2 & 30 & ON2 \\
\hline 23 & P1 & 31 & P1 \\
\hline 24 & P2 & 32 & \\
\hline
\end{tabular}

Posteriormente à realização dos ajustamentos, estimou-se os parâmetros de orientação das imagens e suas respectivas precisões. Analogamente aos experimentos realizados na imagem em visada ré, as precisões dos parâmetros em todos os experimentos se mostraram adequadas às ordens de grandeza dos parâmetros. As variações lineares do ângulo $\kappa$ ficaram em média $40 \% / \mathrm{s}$ para os experimentos de 17 a 20 e de 25 a 28, enquanto que as quadráticas assumiram ordem de grandeza de centésimos de "/s para os experimentos 18, 20, 26 e 28. Para os experimentos de 21 a 24 e de 29 a 32 os padrões de resultado foram idênticos ao grupo de experimentos com a imagem em visada ré, que utilizam os mesmos modelos e configurações de ponto de apoio (experimentos de 5 a 8 e de 13 a 16). Similarmente ao citado nos resultados da imagem em visada ré, a consideração das variações quadráticas de $\kappa$ não foram capazes de alterar significativamente os valores de 
Rodrigues, T.L et al.

acurácia, conforme pode ser visto na Tabela 9 dos RMSE dos pontos de verificação.

De forma semelhante à análise dos resultados das orientações na imagem em visada ré, foram também analisados nas orientações da imagem em visada nadir, o teste do Qui-quadrado sobre as variâncias a priori e posteriori, e os RMSE dos vetores dos resíduos. Conforme apresentado na Tabela 8 a seguir, em todos os experimentos houve aceitação da hipótese básica $\left(\hat{\sigma}_{0}^{2}=\sigma_{0}^{2}\right)$ sobre o teste do Qui-quadrado, e, os RMSE das componentes $x_{s}$ e $y_{s}$ dos vetores dos resíduos ficaram próximos ou abaixo do valor de 1 pixel $(0,0071 \mathrm{~mm})$. Com tais resultados para a imagem em visada nadir, pode-se dizer que os modelos matemáticos funcionais utilizados conseguiram modelar adequadamente a realidade física do processo de orientação. Destaca-se aqui que os valores nos vetores dos resíduos apresentaram as mesmas ordens de grandeza das observações, contribuindo para a aceitação das hipóteses básicas, nas duas configurações de pontos de apoio em todos os experimentos. Neste caso, diferentemente dos experimentos 13 e 14, a possível componente sistemática decorrente da aplicação das injunções absolutas $\omega=0^{\circ}$ e $\varphi=0^{\circ}$ não se mostrou significativa. Tal resultado pode estar associado ao fato da imagem em visada nadir ter sido tomada próxima ao nadir. Também semelhantemente ao caso dos experimentos com a imagem em visada ré, em todos os experimentos as médias das componentes dos vetores dos resíduos foram próximas de zero $\left(10^{-6}\right.$ no máximo).

Tabela 8: Resultados obtidos nos ajustamentos para os experimentos da imagem em visada nadir.

\begin{tabular}{|c|c|c|c|}
\hline $\begin{array}{c}\text { Exp. (MP) com } \\
\text { distribuição de pontos } 1\end{array}$ & Resultados & $\begin{array}{c}\text { Exp. (MP) com } \\
\text { distribuição de pontos } 2\end{array}$ & Resultados \\
\hline $17(\mathrm{~K} 1)$ & $\begin{array}{c}\chi_{\text {calculado }}^{2}: 17,6198 \\
\chi_{\text {teórico }}^{2}(18 ; 0,975): 31,53 \\
\operatorname{RMSE~} x_{s}: 0,0074 \mathrm{~mm} \\
\operatorname{RMSE~} y_{s}: 0,0036 \mathrm{~mm}\end{array}$ & $25(\mathrm{~K} 1)$ & $\begin{array}{c}\chi_{\text {calculado }}^{2}: 9,0213 \\
\chi_{\text {teórico }}(8 ; 0,975): 17.53 \\
\text { RMSE } x_{s}: 0,0073 \mathrm{~mm} \\
\text { RMSE } y_{s}: 0,0019 \mathrm{~mm}\end{array}$ \\
\hline $18(\mathrm{~K} 2)$ & $\begin{array}{c}\chi_{\text {calculado }}^{2}: 16,9440 \\
\chi_{\text {teórico }}^{2}(17 ; 0,975): 30,19 \\
\operatorname{RMSE~} x_{s}: 0,0072 \mathrm{~mm} \\
\operatorname{RMSE~} y_{s}: 0,0037 \mathrm{~mm}\end{array}$ & $26(\mathrm{~K} 2)$ & $\begin{array}{c}\chi_{\text {calculado }}^{2}: 9,0050 \\
\chi_{\text {teórico }}^{2}(7 ; 0,975): 16,01 \\
\text { RMSE } x_{s}: 0,0072 \mathrm{~mm} \\
\text { RMSE } y_{s}: 0,0021 \mathrm{~mm}\end{array}$ \\
\hline $19(\mathrm{~J} 2-1)$ & $\begin{array}{c}\chi_{\text {calculado: }}^{2} 21,2710 \\
\chi_{\text {teórico }}^{2}(18 ; 0,975): 31,53 \\
\operatorname{RMSE~} x_{s}: 0,0083 \mathrm{~mm} \\
\operatorname{RMSE~} y_{s}: 0,0038 \mathrm{~mm}\end{array}$ & $27(\mathrm{~J} 2-1)$ & $\begin{array}{c}\chi_{\text {calculado: }}^{2} 10,7892 \\
\chi_{\text {teórico }}^{2}(8 ; 0,975): 17,53 \\
\text { RMSE } x_{s}: 0,0079 \mathrm{~mm} \\
\text { RMSE } y_{s}: 0,0024 \mathrm{~mm}\end{array}$ \\
\hline $20(\mathrm{~J} 2-2)$ & $\begin{array}{c}\chi_{\text {calculado }}^{2}: 21,2309 \\
\chi_{\text {teórico }}^{2}(17 ; 0,975): 30,19 \\
\text { RMSE } x_{s}: 0,0082 \mathrm{~mm} \\
\operatorname{RMSE~} y_{s}: 0,0039 \mathrm{~mm}\end{array}$ & $28(\mathrm{~J} 2-2)$ & $\begin{array}{c}\chi_{\text {calculado: }}^{2} 10,7891 \\
\chi_{\text {teórico }}^{2}(7 ; 0,975): 16,01 \\
\operatorname{RMSE~} x_{s}: 0,0079 \mathrm{~mm} \\
\operatorname{RMSE~} y_{s}: 0,0025 \mathrm{~mm}\end{array}$ \\
\hline $21(\mathrm{ON} 1)$ & $\begin{array}{c}\chi_{\text {calculado }}^{2}: 19,7926 \\
\chi_{\text {teórico }}^{2}(17 ; 0,975): 30,19 \\
\text { RMSE } x_{s}: 0,0074 \mathrm{~mm} \\
\operatorname{RMSE~} y_{s}: 0,0046 \mathrm{~mm}\end{array}$ & 29 (ON1) & $\begin{array}{c}\chi_{\text {calculado }}^{2}: 8,1828 \\
\chi_{\text {teórico }}^{2}(7 ; 0,975): 16,01 \\
\operatorname{RMSE} x_{s}: 0,0066 \mathrm{~mm} \\
\operatorname{RMSE~} y_{s}: 0,0027 \mathrm{~mm}\end{array}$ \\
\hline
\end{tabular}




\begin{tabular}{|c|c|c|c|}
\hline 22 (ON2) & $\begin{array}{c}\chi_{\text {calculado: }}^{2} 15,8385 \\
\chi_{\text {teórico }}(16 ; 0,975): 28,85 \\
\operatorname{RMSE} x_{s}: 0,0063 \mathrm{~mm} \\
\operatorname{RMSE} y_{s}: 0,0046 \mathrm{~mm}\end{array}$ & 30 (ON2) & $\begin{array}{c}\chi_{\text {calculado: } 2,6666}^{2} \\
\chi_{\text {teórico }}(6 ; 0,975): 14,45 \\
\operatorname{RMSE} x_{s}: 0,0031 \mathrm{~mm} \\
\operatorname{RMSE} y_{s}: 0,0027 \mathrm{~mm}\end{array}$ \\
\hline 23 (P1) & $\begin{array}{c}\chi_{\text {calculado: }}^{2} 10,7595 \\
\chi_{\text {teórico }}(15 ; 0,975): 27,49 \\
\operatorname{RMSE} x_{s}: 0,0058 \mathrm{~mm} \\
\operatorname{RMSE} y_{s}: 0,0029 \mathrm{~mm}\end{array}$ & 31 (P1) & $\begin{array}{c}\chi_{\text {calculado: } 6,9935}^{2} \\
\chi_{\text {teórico }}^{2}(5 ; 0,975): 12,83 \\
\text { RMSE } x_{s}: 0,0066 \mathrm{~mm} \\
\operatorname{RMSE} y_{s}: 0,0005 \mathrm{~mm}\end{array}$ \\
\hline $24(\mathrm{P} 2)$ & $\begin{array}{c}\chi_{\text {calculado: }}^{2} 9,7775 \\
\chi_{\text {teórico }}^{2}(14 ; 0,975): 26,12 \\
\operatorname{RMSE} x_{s}: 0,0054 \mathrm{~mm} \\
\operatorname{RMSE} y_{s}: 0,0029 \mathrm{~mm}\end{array}$ & $32(\mathrm{P} 2)$ & $\begin{array}{c}\chi_{\text {calculado: }}^{2} 0.1802 \\
\chi_{\text {teórico }}^{\text {(4;0,975): } 11,14} \\
\text { RMSE } x_{s}: 0,0009 \mathrm{~mm} \\
\operatorname{RMSE} y_{s}: 0,0005 \mathrm{~mm}\end{array}$ \\
\hline
\end{tabular}

Com os parâmetros estimados, aplicaram-se os mesmos nos modelos de Colinearidade inversos com a finalidade de investigar a acurácia das orientações. Nos valores de $Z_{i}$ foram utilizados os próprios valores dos pontos de verificação. Todas as coordenadas foram transformadas em coordenadas do Sistema Geodésico Local antes desta análise. A Tabela 9 a seguir apresenta a acurácia nas componentes $\mathrm{X}_{\mathrm{L}}$ e $\mathrm{Y}_{\mathrm{L}}$ em todos os experimentos analisados na imagem em visada nadir.

Tabela 9: Acurácia nas componentes $X_{L}$ e $Y_{L}$ para os pontos de verificação nos experimentos da imagem em visada nadir.

\begin{tabular}{c|c|c|c|c|c}
\hline $\begin{array}{c}\text { Exp. (Modelo) } \\
\text { com distribuição } \\
\text { de pontos 1 }\end{array}$ & \multicolumn{2}{|c|}{ RMSE (m) } & \multicolumn{2}{c|}{$\begin{array}{c}\text { Exp. (Modelo) } \\
\text { com distribuição } \\
\text { de pontos 2 }\end{array}$} & \multicolumn{2}{c}{ RMSE (m) } \\
$\mathbf{X}_{\mathbf{L}}$ & $\mathbf{Y}_{\mathbf{L}}$ & $\mathbf{Y}_{\mathbf{L}}$ \\
\hline $17(\mathrm{~K} 1)$ & 0,937 & 1,915 & $25(\mathrm{~K} 1)$ & 1,712 & 2,767 \\
\hline $18(\mathrm{~K} 2)$ & 1,100 & 1,923 & $26(\mathrm{~K} 2)$ & 1,720 & 2,728 \\
\hline $19(\mathrm{~J} 2-1)$ & 1,062 & 1,865 & $27(\mathrm{~J} 2-1)$ & 1,857 & 2,863 \\
\hline $20(\mathrm{~J} 2-2)$ & 1,125 & 1,865 & $28(\mathrm{~J} 2-2)$ & 1,865 & 2,859 \\
\hline $21(\mathrm{ON} 1)$ & 1,640 & 2,448 & $29(\mathrm{ON} 1)$ & 2,393 & 2,433 \\
\hline $22(\mathrm{ON} 2)$ & 1,614 & 1,630 & $30(\mathrm{ON} 2)$ & 2,191 & 2,620 \\
\hline $23(\mathrm{P} 1)$ & 0,765 & 3,007 & $31(\mathrm{P} 1)$ & 5,156 & 3,872 \\
\hline $24(\mathrm{P} 2)$ & 0,789 & 2,475 & $32(\mathrm{P} 2)$ & 5,122 & 4,667 \\
\hline & & & & &
\end{tabular}

Efetuando-se o cálculo dos deslocamentos planimétricos resultantes, a comparação gráfica é apresentada na Figura 4 a seguir. 
Rodrigues, T.L et al.

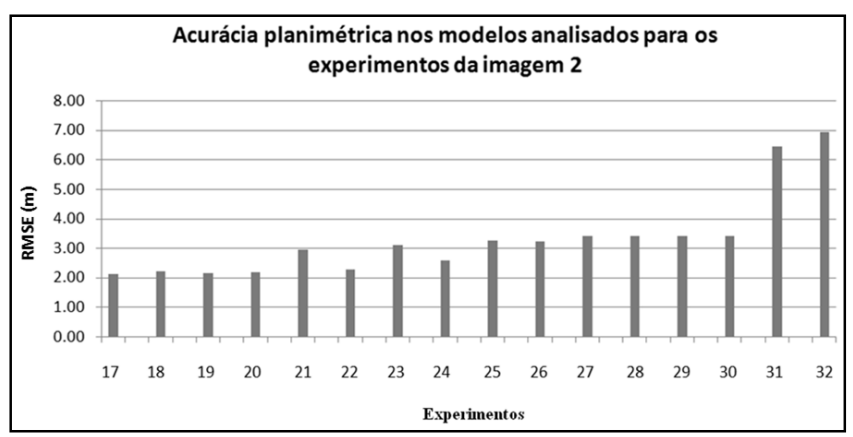

Figura 4: RMSE nos modelos analisados na imagem em visada nadir.

Nota-se a partir da análise da Tabela 9 e da Figura 6 que de forma semelhante ao estudo da imagem em visada ré, a inclusão da variação quadrática do ângulo $\kappa$ não apresentou influencia significativa (diferença máxima na ordem do decímetro) na acurácia das orientações, apresentando-se por vezes pouco melhor ou pior. A inflexibilidade dos modelos polinomiais quanto à quantidade de pontos de apoio e a acurácia posicional, verificada no estudo da imagem em visada ré, ocorreu apenas para os modelos P1 e P2 neste estudo da imagem em visada nadir. Para os demais modelos usando as duas configurações de distribuição de pontos de apoio, os resultados de acurácia planimétrica não se alteraram de forma significativa (menor que 1 pixel). Também de forma contrária ao estudo da imagem em visada ré, os experimentos que utilizaram os modelos ON1 e ON2 apresentaram resultados de acurácia planimétrica mais próximos dos resultados dos outros modelos. Conforme já citado na análise da precisão dos ajustamentos, isso pode ter ocorrido em função da imagem ter sido tomada próxima ao nadir, concordando mais com a ideia das injunções absolutas aplicadas $\omega$ $=0^{\circ}$ e $\varphi=0^{\circ}$. De uma forma geral, para as duas distribuições de pontos de apoio, as acurácias planimétricas obtidas pelos modelos K1, K2, J2-1 e J2-2 apresentaram-se próximas das obtidas pelos demais modelos, com exceção dos modelos P1 e P2 nos experimentos 31 e 32. Com relação à adaptação dos modelos K1, K2, J2-1 e J2-2 ao uso de coordenadas referenciadas ao Sistema de Coordenadas Geocêntricas Cartesianas Terrestres mostrou-se adequada, visto os valores de RMSE apresentarem-se em torno de 1 pixel ou pouco mais $(\sim \mathrm{dm})$ que o valor métrico deste. Por fim, observou-se também que a inserção do termo que modela a perturbação orbital do satélite proveniente da atração gravitacional terrestre devido a sua elipticidade, não alterou significativamente as acurácias planimétricas, apresentando por vezes resultados ligeiramente melhores ou piores em relação aos modelos que não as consideraram.

Em relação à análise de presença de tendências, realizou-se também testes de hipótese utilizando a distribuição $t$ de student, com as mesmas configurações dos experimentos com a imagem 1 . Os resultados são apresentados na Tabela 10.

Tabela 10: Testes de tendência para os experimentos da imagem em visada nadir.

\begin{tabular}{|c|c|c|c|c|c|c|c|}
\hline $\begin{array}{l}\text { Exp. } \\
\text { (MP) }\end{array}$ & $\begin{array}{c}\mathbf{t} \\
\text { calc. } \\
/ \\
\text { Com } \\
\mathbf{p .} \\
\mathbf{X}_{\mathbf{L}}\end{array}$ & $\begin{array}{c}\mathbf{t} \\
\text { calc. } \\
/ \\
\text { Com } \\
\text { p. } \\
\mathbf{Y}_{\mathbf{L}}\end{array}$ & $\begin{array}{c}\mathbf{t} \\
(\mathbf{g l} ; 0,97 \\
\mathbf{5})\end{array}$ & $\begin{array}{l}\text { Exp. } \\
\text { (MP) }\end{array}$ & $\begin{array}{c}t \text { calc./ } \\
\text { Comp. } \\
\text { X }_{L}\end{array}$ & $\begin{array}{c}t \text { calc./ } \\
\text { Comp } \\
. Y_{L}\end{array}$ & $\begin{array}{c}\text { t } \\
(\mathrm{gl} ; \mathbf{0 , 9 7} \\
\mathbf{5})\end{array}$ \\
\hline 17 (K1) & $\begin{array}{c}1,20 \\
4\end{array}$ & $\begin{array}{c}1,61 \\
5\end{array}$ & 2,306 & $25(\mathrm{~K} 1)$ & 1,573 & 1,709 & 2,160 \\
\hline
\end{tabular}




\begin{tabular}{c|c|c|c|c|c|c|c}
\hline $18(\mathrm{~K} 2)$ & $\begin{array}{c}1,29 \\
5\end{array}$ & $\begin{array}{c}1,59 \\
0\end{array}$ & 2,306 & $26(\mathrm{~K} 2)$ & 1,556 & 1,719 & 2,160 \\
\hline $\begin{array}{c}19(\mathrm{~J} 2- \\
1)\end{array}$ & $\begin{array}{c}1,28 \\
9\end{array}$ & $\begin{array}{c}1,65 \\
2\end{array}$ & 2,306 & $27(\mathrm{~J} 2-1)$ & 1,264 & 1,694 & 2,160 \\
\hline $\begin{array}{c}20(\mathrm{~J} 2- \\
2)\end{array}$ & $\begin{array}{c}1,23 \\
5\end{array}$ & $\begin{array}{c}1,65 \\
8\end{array}$ & 2,306 & $28(\mathrm{~J} 2-2)$ & 1,254 & 1,694 & 2,160 \\
\hline $\begin{array}{c}21 \\
(\mathrm{ON} 1)\end{array}$ & $\begin{array}{c}1,80 \\
3\end{array}$ & $\begin{array}{c}1,67 \\
6\end{array}$ & 2,306 & $29(\mathrm{ON} 1)$ & 1,694 & 1,269 & 2,160 \\
\hline $\begin{array}{c}22 \\
(\mathrm{ON} 2)\end{array}$ & $\begin{array}{c}1,43 \\
1\end{array}$ & $\begin{array}{c}0,97 \\
6\end{array}$ & 2,306 & $30(\mathrm{ON} 2)$ & 1,497 & 1,923 & 2,160 \\
\hline $23(\mathrm{P} 1)$ & $\begin{array}{c}1,14 \\
2\end{array}$ & $\begin{array}{c}1,33 \\
7\end{array}$ & 2,306 & $31(\mathrm{P} 1)$ & 1,022 & 1,482 & 2,160 \\
\hline $24(\mathrm{P} 2)$ & $\begin{array}{c}1,17 \\
5\end{array}$ & $\begin{array}{c}1,28 \\
0\end{array}$ & 2,306 & $32(\mathrm{P} 2)$ & 0,913 & 1,395 & 2,160 \\
\hline
\end{tabular}

Nota-se a partir da Tabela 10 que, assim como nos experimentos com a imagem 1, nenhum experimento apresentou tendência ao nível de confiança de $95 \%$ para ambas as componentes $\mathrm{X}_{\mathrm{L}}$ e $Y_{L}$.

\section{CONCLUSÕES E RECOMENDAÇÕES}

A partir da análise feita sobre os resultados provenientes da utilização da variação linear ou quadrática do ângulo $\kappa$, em ambos os grupos de experimentos, verificou-se que a diferença na acurácia das orientações não se modificou de forma significativa.

Com relação à adaptação dos Modelos de Kepler e órbita perturbada J2 ao uso de coordenadas referenciadas ao Sistema de Coordenadas Geocêntricas Cartesianas Terrestres, para todos os experimentos os resultados se mostraram adequados, tendo em vista que os valores de RMSE alcançaram valores em torno de 1 pixel. Isto possibilita a eliminação da necessidade primária de transformação das coordenadas do espaço objeto para o Sistema de Coordenadas Geocêntrico Cartesiano Inercial.

$\mathrm{Na}$ análise final sobre as acurácias das orientações, para a imagem em visada ré com a primeira distribuição de pontos de apoio, com 14 pontos de apoio e 9 pontos de verificação (Figura 2a), os modelos de Kepler e os modelos considerando a aceleração devido ao geopotencial apresentaramse próximos, com resultados pouco melhores do que os modelos polinomiais com e sem injunções absolutas em $\omega$ e $\varphi$. Já na segunda distribuição, com 9 pontos de apoio e 14 pontos de verificação (Figura 2b), a melhora foi mais significativa, atingindo diferenças métricas. Para ambas as distribuições de pontos, os experimentos que utilizaram os modelos polinomiais, com injunções absolutas em $\omega$ e $\varphi$, apresentaram resultados menos acurados do que os dos experimentos com os modelos polinomiais sem a aplicação das injunções. A causa de tais resultados é a aplicação das injunções absolutas nos ângulos $\omega$ e $\varphi$ ao invés de estimá-los como parâmetros nos ajustamentos.

Ainda com relação às acurácias, no caso da imagem em visada nadir, em ambas as distribuições de pontos de apoio, as acurácias planimétricas obtidas pelos modelos de Kepler, e pelos modelos considerando a aceleração devido ao geopotencial, apresentaram-se próximas das obtidas pelos demais modelos. A exceção ocorreu comparando-se aos resultados do modelo polinomial, sem 
injunções absolutas em $\omega$ e $\varphi$, na segunda distribuição de pontos de apoio. Ao contrário dos resultados da imagem em visada ré, os experimentos que utilizaram os modelos polinomiais, com injunções absolutas em $\omega$ e $\varphi$, apresentaram resultados de acurácia planimétrica mais próximos dos resultados dos outros modelos, possivelmente pelas injunções absolutas aplicadas $\left(\omega=0^{\circ}\right.$ e $\varphi$ $=0^{\circ}$ ) representarem mais acuradamente a situação física de obtenção da imagem em visada nadir.

Ao analisar a flexibilidade na quantidade e distribuição de pontos de apoio sobre as imagens, com relação aos resultados de acurácia, houve também divergência. Para a imagem em visada ré observou-se uma menor flexibilidade nos modelos polinomiais, no sentido de que quanto menos pontos, menor a acurácia. Já para a imagem em visada nadir, a quantidade reduzida de pontos proporcionou piores resultados de acurácia somente para os modelos polinomiais sem injunções absolutas em $\omega$ e $\varphi$.

Como apresentado, os resultados das orientações das duas imagens com o modelo considerando a aceleração devido ao geopotencial se mostraram muitos próximos das orientações com o Modelo de Kepler. Ou seja, a inserção no Modelo de Kepler do termo que modela a perturbação orbital do satélite proveniente da atração gravitacional terrestre devido a sua elipticidade, não alterou os resultados de forma significativa em relação ao uso do Movimento Kepleriano no modelo de plataforma. Desta forma, para os casos de orientação exterior de apenas uma imagem, qualquer um dos dois modelos pode ser utilizado. Cabe ressaltar que os resultados para o Modelo de Kepler obtidos nesta pesquisa concordaram em ordem de grandeza com os obtidos por Dowman et al. (2011) e Michalis e Dowman (2010).

Deve-se ainda verificar em trabalhos futuros se há influência ou não da consideração da aceleração proposta pelo potencial gravitacional terrestre devido a sua elipticidade, representado pelo harmônico zonal de grau 2 (J2), nos casos de fototriangulação com imagens na mesma órbita, na mesma data, conforme proposto em Michalis (2005). Isto é, utilizando-se apenas a posição e velocidade da primeira linha da primeira imagem do tripleto PRISM-ALOS e propagando a órbita durante todo o imageamento do tripleto (105 segundos). Recomenda-se ainda a realização de experimentos com menos pontos de apoio e com uma distribuição geométrica ruim, a fim de verificar o potencial dos modelos que utilizam os dados orbitais na estimação dos POEs que descrevem a trajetória da plataforma.

\section{AGRADECIMENTOS}

Os autores agradecem ao Departamento de Cartografia da Faculdade de Ciências e Tecnologia da Universidade Estadual Paulista, campus de Presidente Prudente, por ceder as imagens e pontos de apoio utilizados nesta pesquisa.

\section{REFERÊNCIAS BIBLIOGRÁFICAS}

Bang, Kiin, and Cho, Woosang "Analysis of EOC Sensor Model". Paper presented at the FIG Working Week, Seoul, Korea, May 6-11, 2001.

Bate, Roger R., Mueller, Donald D., and White, Jerry. Fundamentals of Astrodynamics. Dover, 1971. 
Dowman, Ian, and Michalis, Pantelis "Generic rigorous model for along track stereo satellite sensors". Paper presented at the ISPRS workshop on High resolution mapping from Space, Hanover, Niedersachsen, October 4-6, 2003.

Dowman, Ian, Michalis, P., and Li, Zhenhong "Analysis of Urban Landscape Using Multi Sensor Data". Paper presented at the $4^{\text {th }}$ ALOS PI Symposium, Tokyo, Japan, November 15-17, 2010.

Gemael, Camil. Introdução ao ajustamento de observações: aplicações geodésicas. Curitiba: UFPR, 1994.

Gugan, David, and Dowman, Ian. "Topographic mapping from SPOT imagery" Photogrammetric Engineering \& Remote Sensing 54 (1988): 1409-14. Acessed November 11, 2011. doi: 10.1111/j.1477-9730.1987.tb00581.x.

Jacobsen, Karsten "Orientation of high resolution optical space images". Paper presented at the ASPRS 2007 Annual Conference, Tampa, Flórida, May 7-11, 2007.

Japan Aerospace Exploration Agency - JAXA, ALOS User Handbook, 2007. Acessed November 11, 2011. http://www.eorc.jaxa.jp/ALOS/en/doc/alos_userhb_en.pdf.

Jeong, In-seong, and Bethel, James "Trajectory modeling for satellite image triangulation". Paper presented at the XXI ISPRS Congress, Comission I, Beijing, China, July 3-11, 2008.

Kocaman, Sultan, and Armin Gruen "Geometric modeling and validation of ALOS/PRISM imagery and products". Paper presented at the XXI ISPRS Congress, Comission I, Beijing, China, July 3-11, 2008.

Kim, Taejung and Dowman, Ian. "Comparison of two physical sensor models for satellite images: Position-Rotation model and Orbit-Attitude model" The Photogrammetric Record 21 (2006): 110 23. Acessed May 23, 2009. doi: 10.1111/j.1477-9730.2006.00363.x.

Leick, Alfred. GPS Surveying. New Jersey: John Wiley \& Sons, 2004.

Light, Donald L. "Satellite Photogrammetry" In Manual of Photogrammetry, edited by Chester C. Slama, Charles Theurer,and Soren W. Henriksen, 883-977. Virginia: American Society of Photogrammetry, 1980.

Marcato Junior, José and Tommaselli, Antonio Maria Garcia. "Exterior orientation of CBERS-2B imagery using multi-feature control and orbital data" ISPRS Journal of Photogrammetry and Remote Sensing 79 (2013): 219-25. Acessed January 27, 2015. doi: 10.1016/j.isprsjprs.2013.02.018.

Marcato Junior et al., "Orientação de imagens CBERS-2B usando o modelo rigoroso de colinearidade com dados orbitais" Boletim de Ciências Geodésicas 17 (2011): 401- 16. Acessed November 11, 2012. doi: 10.1590/S1982-21702011000300005.

Michalis, Pantelis. "Generic rigorous model for along track stereo satellite sensors." PhD diss., University College London, 2005.

Michalis, Pantelis, and Dowman, Ian "A rigorous model and DEM generation for SPOT5-HRS". Paper presented at the XX ISPRS Congress, Comission I, Istanbul, Turkey, July 12-23, 2004.

Michalis, Pantelis, and Dowman, Ian. "A Generic Model for Along Track Stereo Sensors Using Rigorous Orbit Mechanics" Photogrammetric Engineering and Remote Sensing 74 (2008a): 30309. Acessed July 13, 2011. doi: 10.14358/PERS.74.3.303.

Michalis, Pantelis, and Dowman, Ian "Exterior orientation improved by the coplanarity equation and DEM generation for Cartosat-1". Paper presented at the XXI ISPRS Congress, Comission I, Beijing, China, July 3-11, 2008 b.

Michalis, Pantelis, and Dowman, Ian "Noise-Reduction and exterior orientation improvement by the coplanarity equation for ALOS-PRISM". Paper presented at the $4^{\text {th }}$ ALOS PI Symposium, Tokyo, Japan, November 15-17, 2010.

Orun, Ahmet B, and Natarajan, Krishnaler . "A Modified Bundle Adjustment Software for SPOT Imagery and Photography: Tradeoff" Photogrammetric Engineering and Remote Sensing 60 (1994): 1431-37. 
Poli, Daniela. "A Rigorous Model for Spaceborne Linear Array Sensors" Photogrammetric Engineering and Remote Sensing 73 (2007): 187 - 96. Acessed November 11, 2011. doi: 10.14358/PERS.73.2.187.

Radhadevi, Pullur V, Sasikumar, T.P., and Ramachandran, Rajaraman. "Orbit attitude modelling and derivation of ground co-ordinates from spot stereopairs" Journal of Photogrammetry and Remote Sensing 49 (1994): 22-28. Acessed April 17, 2009. doi: 10.1016/0924-2716(94)90043-4.

Rodrigues, Tiago L, and Ferreira, Luiz Danilo Damasceno “Aplicação do movimento kepleriano na orientação de imagens HRC - CBERS 2B" Boletim de Ciências Geodésicas 19 (2013): 11434. Acessed May 1, 2013. doi: 10.1590/S1982-21702013000100008.

Salamonowick, Paul H. "Satellite orientation and position for geometric correction of scanner imagery" Photogrammetric Engineering and Remote Sensing 52 (1986): 491-99.

Satoru, Watanabe, and Akiriho, Hirao "Development of the Earth Observation Satellite "DAICHI" (ALOS)" NEC Technical Journal 6 (2011): 62-66.

Seeber, Günter. Satellite Geodesy: foundations, methods, and applications. Berlim: Walter de Gruyter, 2003.

Toledo et al., "Fototriangulação em bloco de imagens ALOS/PRISM para mapeamento na escala 1:25000 da região de Presidente Prudente - SP" Trabalho de conclusão de curso de graduação, Universidade Estadual Paulista, 2010.

Torgue, Wolfgang. Geodesy. Berlin; New York: Walter de Gruyter, 2001.

Toutin, Thierry "Geometric processing of Remote Sensing images: models, algorithms and methods" International Journal of Remote Sensing 25 (2004): 1893-924. Acessed April 13, 2009. doi: 10.1080/0143116031000101611.

Weser et al., "Development and testing of a generic sensor model for pushbroom satellite imagery" The Photogrammetric Record 23 (2008): 255-74. Acessed November 11, 2011. doi: 10.1111/j.1477-9730.2008.00489.x.

Recebido em Novembro de 2014. Aceito em Março de 2015. 



\title{
A NOTE ON THE CONVENTIONAL OUTLIER DETECTION TEST PROCEDURES
}

\author{
Considerações sobre testes convencionais de detecção de ouliers
}

\author{
JIANFENG GUO \\ Info Engineering University, P.O.Box 603, 62 Kexuedadao Rd, 450001, Zhengzhou, China \\ Email: jianfeng.guo@gmail.com
}

\begin{abstract}
:
Under the assumption of that the variance-covariance matrix is fully populated, Baarda's w-test is turn out to be completely different from the standardized least-squares residual. Unfortunately, this is not generally recognized. In the limiting case of only one degree of freedom, all the three types of test statistics, including Gaussian normal test, Student's t-test and Pope's Tau-test, will be invalid for identification of outliers: (1) all the squares of the Gaussian normal test statistic coincide with the goodness-of-fit (global) test statistic, even for correlated observations. Hence, the failure of the global test implies that all the observations will be flagged as outliers, and thus the Gaussian normal test is inconclusive for localization of outliers; (2) the absolute values of the Tau-test statistic are all exactly equal to one, no matter whether the observations are contaminated. Therefore, the Tau-test cannot work for outlier detection in this situation; and (3) Student's t-test statistics are undefined.
\end{abstract}

Keywords: Outlier; Gaussian normal test; Student's t-test; Tau-test; RAIM.

\section{Resumo:}

Assumindo que a matriz Variância-Covariância das observações foi obtida, a análise dos resíduos obtidos pelos mínimos quadrados não corresponde ao teste w de Baarda. Geralmente, esta consideração não é aceita na comunidade. Em casos especiais, onde os graus de liberdade são igual a 1 (um), todos os 3 (três) tipos de testes estatísticos, incluindo o teste de normalidade de Gauss, o teste t-Students e o teste Tau-Pope, não podem ser aplicados para detecção de outliers: (1) todos os quadrados do teste de normalidade de Gauss, coincidem com o teste estatístico global, mesmo para observações correlacionadas. Assim, a falha do teste global implica em observações classificadas como outliers e, então, o teste de normalidade de Gauss é inconclusivo para a detecção de outliers; (2) os valores absolutos do teste Tau são exatamente iguais a um, não importando se as observações estão eivadas de erros. Portanto, nesta situação, o teste Tau não é eficiente para detecção de outliers, e (3) as estatísticas do teste t-Student são indefinidas.

Palavras-chave: Oultier; Teste de normalidade de Gauss; Teste t-Student; Teste Tau; RAIM. 


\section{Introduction}

Least-squares (LS) estimation is the predominant technique for geodetic data processing. However, LS estimation is sensitive to outliers (Wolf and Ghilani, 1997; Koch, 1999; Leick, 2004). One way to circumvent this difficulty is to adopt the conventional outlier detection test procedures (see e.g., Baarda, 1968; Pope, 1976; Kok, 1984). In these procedures, the test statistics used for outlier identification include those of the Gaussian normal test, Student's t-test and Pope's $\tau$-test. All these test statistics can be based on Baarda's w-test or the standardized LS residual.

It should be pointed out that Baarda's w-test statistic coincides with the standardized LS residual under the diagonality assumption of the weight matrix. However, these two kinds of test statistics may be completely different in the case of correlated observations. Unfortunately, this is not generally recognized (Guo et al., 2010).

Baselga (2011) presented an angular resection problem with one redundancy, in which the observations were supposed to be uncorrelated. Numerical results state that the standardized LS residual flags all observations. One interesting problem is that of determining whether the conventional outlier detection test procedures, for uncorrelated or correlated observations, can work in the limiting case of only one degree of freedom.

The paper is organized as follows: Firstly, the conventional outlier detection test procedures are briefly overviewed. Under the condition of one redundancy, limitations of three types of test statistics used for outlier identification are addressed. An example associated with a GPS baseline RAIM (Receiver Autonomous Integrity Monitoring) scheme concludes the investigations.

\section{Model description}

Consider the linear Gauss-Markov model defined by Koch (1999)

$$
E(\boldsymbol{L})=\boldsymbol{A} \boldsymbol{X} \text { with } \operatorname{Cov}(\boldsymbol{L})=\sigma^{2} \boldsymbol{P}^{-1}
$$

where $\boldsymbol{L}$ is the $n \times 1$ vector of normally distributed observations, $\boldsymbol{A}$ the $n \times u$ design matrix with full column rank, $\mathbf{X}$ the $u x l$ vector of unknowns, $\mathbf{P}$ the weight matrix of $\boldsymbol{L}$ and $\boldsymbol{\sigma}^{2}$ the a-priori variance factor of unit weight.

The weighted LS estimator of the unknowns in model (1) is obtained as

$$
\hat{\boldsymbol{X}}=\left(\boldsymbol{A}^{T} \boldsymbol{P} \boldsymbol{A}\right)^{-1} \boldsymbol{A}^{T} \boldsymbol{P L}
$$

and the LS residual vector as

$$
\boldsymbol{V}=\boldsymbol{L}-\boldsymbol{A X}=\boldsymbol{R} \boldsymbol{L}
$$

where $\boldsymbol{R}=\boldsymbol{I}-\boldsymbol{A}\left(\boldsymbol{A}^{T} \boldsymbol{P A}\right)^{-1} \boldsymbol{A}^{T} \boldsymbol{P}$. The matrix $\mathbf{R}$ plays a pivotal role in linear adjustment techniques since it contains extremely useful information (Huber and Ronchetti, 2009; Guo, 2014).

The formulation for the most fundamental test statistic in LS estimation is given by 


$$
\frac{\boldsymbol{V}^{T} \boldsymbol{P} \boldsymbol{V}}{\sigma^{2}}=\frac{\hat{\sigma}^{2}}{\sigma^{2}}(n-u) \sim \chi^{2}(n-u)
$$

Under the assumption of normality, based on this statistic, the goodness-of-fit test (Wolf and Ghilani, 1997; Leick, 2004) can be performed to find out whether the adjustment results are valid.

\section{Mean-shift outlier detection model}

In conventional outlier detection test procedures, it is usually assumed that there is only one (possible) outlier exists in the observations (see Baarda, 1968; Pope, 1976; Baselga, 2011). Let us assume that an outlier exists in the $\boldsymbol{i}$ th observation so that the mean-shift outlier model should have read (Chatterjee and Hadi, 1988)

$$
E(\boldsymbol{L})=\boldsymbol{A} \boldsymbol{X}+\boldsymbol{c}_{i} \nabla_{i} \text { with } \operatorname{Cov}(\boldsymbol{L})=\sigma^{2} \boldsymbol{P}^{-1},
$$

where $\left[\begin{array}{ll}\boldsymbol{A} & \mathbf{c}_{i}\end{array}\right]$ has full column rank and $\boldsymbol{c}_{i}$ is the $\boldsymbol{i}$ th canonical unit vector with all zeros except for a one as its $i$ th entry.

By employing the LS principle, one obtains the estimates

$$
\left\{\begin{array}{l}
\hat{\nabla}_{i}=\left(\boldsymbol{c}_{i}^{T} \boldsymbol{P} \boldsymbol{R} \boldsymbol{c}_{i}\right)^{-1} \boldsymbol{c}_{i}^{T} \boldsymbol{P} \boldsymbol{R} \boldsymbol{L} \\
\hat{\boldsymbol{X}}_{[i]}=\left(\boldsymbol{A}^{T} \boldsymbol{P} \boldsymbol{A}\right)^{-1} \boldsymbol{A}^{T} \boldsymbol{P}\left(\boldsymbol{L}-\boldsymbol{c}_{i} \hat{\nabla}_{i}\right)
\end{array}\right.
$$

since

$$
\boldsymbol{P R}=\boldsymbol{R}^{T} \boldsymbol{P}=\boldsymbol{R}^{T} \boldsymbol{P R}
$$

Therefore, the residual vector of the above mean-shift outlier model is given by

$$
\begin{aligned}
\boldsymbol{V}_{[i]} & =\boldsymbol{L}-\boldsymbol{c}_{i} \hat{\nabla}_{i}-\boldsymbol{A} \hat{\boldsymbol{X}}_{[i]} \\
& =\boldsymbol{R}\left(\boldsymbol{L}-\boldsymbol{c}_{i} \hat{\nabla}_{i}\right)=\boldsymbol{V}-\boldsymbol{R} \boldsymbol{c}_{i} \hat{\nabla}_{i}
\end{aligned}
$$

It follows that

$$
\begin{aligned}
\boldsymbol{V}_{[i]}^{T} \boldsymbol{P} \boldsymbol{V}_{[i]} & =\boldsymbol{L}^{T} \boldsymbol{P}\left(\boldsymbol{V}-\boldsymbol{R} \boldsymbol{c}_{i} \hat{\nabla}_{i}\right)-0 \\
& =\boldsymbol{L}^{T} \boldsymbol{P} \boldsymbol{V}-\left(\boldsymbol{c}_{i}^{T} \boldsymbol{P} \boldsymbol{R} \boldsymbol{L}\right)^{2}\left(\boldsymbol{c}_{i}^{T} \boldsymbol{P} \boldsymbol{R} \boldsymbol{c}_{i}\right)^{-1} \\
& =\boldsymbol{V}^{T} \boldsymbol{P} \boldsymbol{V}-\sigma^{2} w_{i}^{2}
\end{aligned}
$$

in which

$$
w_{i}=\frac{\boldsymbol{c}_{i}^{T} \boldsymbol{P} \boldsymbol{R} \boldsymbol{L}}{\sigma \sqrt{\boldsymbol{c}_{i}^{T} \boldsymbol{P} \boldsymbol{R} \boldsymbol{c}_{i}}} \sim \mathcal{N}(0,1)
$$

is the $\boldsymbol{i}$ th Baarda's w-test statistic (Baarda, 1968). 


\section{Three kinds of test statistics used for outlier detection}

Three different test statistics, including those for the Gaussian normal test, Pope's $\tau$-test and Student's t-test, are used in conventional outlier detection procedures.

With the aid of the mean-shift outlier model (Chatterjee and Hadi, 1988; Guo, 2013), the problem of outlier identification in model (1) can be carried out in terms of the following hypothesis in model (5)

$$
H_{0 i}: \nabla_{i}^{2}=0 \text { vs. } H_{a i}: \nabla_{i}^{2}>0 \text {. }
$$

The test statistic

$$
T_{i}=w_{i}^{2}=\frac{\left(\boldsymbol{c}_{i}^{T} \boldsymbol{P} \boldsymbol{R} \boldsymbol{L}\right)^{2}}{\sigma^{2} \boldsymbol{c}_{i}^{T} \boldsymbol{P} \boldsymbol{R} \boldsymbol{c}_{i}},
$$

defines the uniformly most powerful test for testing $H_{0 i}$ versus $H_{a i}$ at a given level of significance (Baarda, 1968; Kargoll, 2007; Guo et al., 2010), provided that no other outliers exist.

In practice, it is more convenient to use the square root of the test statistic $\mathrm{T}_{i}$, namely, the Baarda's w-test statistic $w_{i}$ (Baarda, 1968). If the variance factor is unknown, the parameter $\sigma$ involved in the w-test may be replaced by its estimate. This will lead to either Pope's $\tau$-test statistic

$$
\tau_{i}=\frac{w_{i}}{\sqrt{\hat{\sigma}^{2} / \sigma^{2}}} \sim \tau(n-u) .
$$

or to Student's t-test statistic

$$
t_{i}=\frac{w_{i}}{\sqrt{\hat{\sigma}_{[i]}^{2} / \sigma^{2}}} \sim t(n-u-1)
$$

with

$$
\hat{\sigma}_{[i]}^{2}=\boldsymbol{V}_{[i]}^{T} \boldsymbol{P} \boldsymbol{V}_{[i]} /(n-u-1)
$$

The standardized LS residual

$$
\tilde{v}_{i}=\frac{v_{i}}{\sigma \sqrt{\boldsymbol{c}_{i}^{T} \boldsymbol{R P}^{-1} \boldsymbol{c}_{i}}} \sim \mathcal{N}(0,1)
$$

has been extensively employed to test whether the $i$ th observation is an outlier, both in the geodetic and the statistical literature, always assuming that the variance factor is given.

If the variance factor is unknown, either the so-called internally Studentized residual

$$
\tilde{\tau}_{i}=\frac{\tilde{v}_{i}}{\sqrt{\hat{\sigma}^{2} / \sigma^{2}}} \sim \tau(n-u)
$$

or the externally Studentized residual 


$$
\tilde{t}_{i}=\frac{\tilde{v}_{i}}{\sqrt{\hat{\sigma}_{[i]}^{2} / \sigma^{2}}} \sim t(n-u-1)
$$

can be used instead of the standardized LS residual.

\section{Limitation of conventional outlier detection test procedures}

Conventional outlier detection test procedures have been used in many geodetic applications. However, can these procedures still work if there is only one degree of freedom, namely $n-u=$ 1 ?

In this limiting case, there is no redundancy in the mean-shift outlier model (5). This implies immediately that

$$
\boldsymbol{V}_{[i]}=0
$$

which, in combination with (9) and (12) yields

$$
w_{i}^{2}=\boldsymbol{V}^{T} \boldsymbol{P} \boldsymbol{V} / \sigma^{2}
$$

and thus

$$
w_{i}^{2} \equiv(n-u) \hat{\sigma}^{2} / \sigma^{2} \sim \chi^{2}(1), \text { for } i=1,2, \cdots, n
$$

since $n-u=1$.

By virtue of (9), (20) can be rewritten as

$$
\boldsymbol{L}^{T} \frac{\boldsymbol{R}^{T} \boldsymbol{P} \boldsymbol{c}_{i} \boldsymbol{c}_{i}^{T} \boldsymbol{P} \boldsymbol{R}}{\boldsymbol{c}_{i}^{T} \boldsymbol{P} \boldsymbol{R} \boldsymbol{c}_{i}} \boldsymbol{L}=\sigma^{2} w_{i}^{2}=\boldsymbol{V}^{T} \boldsymbol{P} \boldsymbol{V}=\boldsymbol{L}^{T} \boldsymbol{P} \boldsymbol{R} \boldsymbol{L}
$$

Since these two quadratic forms coincide for any realization of the random observation vector $\boldsymbol{L}$, and since both $\boldsymbol{R}^{T} \boldsymbol{P} c_{i} \boldsymbol{c}_{i}{ }_{i}^{T} \boldsymbol{P}$ and $\boldsymbol{P R}$ are symmetric, one can obtain

$$
\frac{\boldsymbol{P R} \boldsymbol{c}_{i} \boldsymbol{c}_{i}^{T} \boldsymbol{R}^{T} \boldsymbol{P}}{\boldsymbol{c}_{i}^{T} \boldsymbol{P} \boldsymbol{R} \boldsymbol{c}_{i}}=\boldsymbol{P R}
$$

It follows immediately that

$$
\frac{\boldsymbol{c}_{i}^{T} \boldsymbol{R} \boldsymbol{c}_{i} \boldsymbol{c}_{i}^{T} \boldsymbol{R}^{T} \boldsymbol{c}_{i}}{\boldsymbol{c}_{i}^{T} \boldsymbol{P} \boldsymbol{R} \boldsymbol{c}_{i}}=\boldsymbol{c}_{i}^{T} \boldsymbol{R} \boldsymbol{P}^{-1} \boldsymbol{c}_{i}
$$


and

$$
\frac{\boldsymbol{c}_{i}^{T} \boldsymbol{R} \boldsymbol{c}_{i} \boldsymbol{c}_{i}^{T} \boldsymbol{P R L}}{\boldsymbol{c}_{i}^{T} \boldsymbol{P} \boldsymbol{R} \boldsymbol{c}_{i}}=\boldsymbol{c}_{i}^{T} \boldsymbol{R L}
$$

Therefore, with the definition of $9 / c$ it follows that

$$
\begin{aligned}
\tilde{v}_{i} & =\frac{\boldsymbol{c}_{i}^{T} \boldsymbol{R} \boldsymbol{c}_{i} \boldsymbol{c}_{i}^{T} \boldsymbol{P R \boldsymbol { L }}}{\sigma \cdot \boldsymbol{c}_{i}^{T} \boldsymbol{P} \boldsymbol{R} \boldsymbol{c}_{i}} / \sqrt{\frac{\boldsymbol{c}_{i}^{T} \boldsymbol{R} \boldsymbol{c}_{i} \boldsymbol{c}_{i}^{T} \boldsymbol{R} \boldsymbol{c}_{i}}{\boldsymbol{c}_{i}^{T} \boldsymbol{P} \boldsymbol{R} \boldsymbol{c}_{i}}} \\
& =\operatorname{sgn}\left(\boldsymbol{c}_{i}^{T} \boldsymbol{R} \boldsymbol{c}_{i}\right) \cdot w_{i}
\end{aligned}
$$

which in combination with (21) yields

$$
w_{i}^{2}=\tilde{v}_{i}^{2} \equiv \hat{\sigma}^{2} / \sigma^{2} \sim \chi^{2}(1), \text { for } i=1,2, \cdots, n \text {. }
$$

where $\operatorname{sgn}(\cdot)$ denotes the signum function.

Substituting (21) into (13) gives

$$
\tau_{i}=\operatorname{sgn}\left(w_{i}\right)
$$

Analogically, the following result can be obtained

$$
\tilde{\tau}_{i}=\operatorname{sgn}\left(\tilde{v}_{i}\right)
$$

With (21), and (27) - (29) one can conclude that, in the limiting case of only one degree of freedom, (1) the Student's t-test statistics are undefined (degenerate); (2) all the squares of Gaussian normal test coincide with the goodness-of-fit (global) test, even for correlated observations. That is, the failure of the global test implies all the observations will be flagged as outliers, and thus the Gaussian normal test is invalid for localization of outliers; and (3) the $\tau$-test also becomes inappropriate, because the absolute values of the $\tau$-test statistics equal to one no matter whether the observations are contaminated by outliers.

These results can be used in GPS Receiver Autonomous Integrity Monitoring (RAIM) scenario. The GPS receiver needs at least four satellites to yield a three-dimensional position (latitude, longitude, and altitude) and time solution. In order for a GPS receiver to perform RAIM or fault detection function, a minimum of five visible satellites with satisfactory geometry must be visible to it. However, six or more satellites are required to identify the faulty satellite and exclude it from the navigation solution (Parkinson and Axelrad, 1988; Brown, 1992; Langley 1999).

\section{An illustrative example}

The differential GPS positioning technique (Leick, 2004) has been widely used to cancel all error sources common to two GPS receivers on a short baseline. A static experimental data set was collected with a sampling interval of 1 second and a cut-off elevation angle of $15^{\circ}$ on 3 August 2005, in Wuhan, China. The length of the baseline is approximately $6 \mathrm{~km}$. At a special measurement epoch, only five satellites were visible. The satellites were PRN 19, 27, 8, 11 and 
28. The numerical details of the linearized GPS double-differenced (DD) pseudorange equations are presented in Table 1.

Table 1: Numerical details of the linearized GPS DD pseudorange equations

\begin{tabular}{ccc|c|cccc}
\hline \multicolumn{3}{c|}{ Design matrix } & Observations & \multicolumn{4}{|c}{ Variance-covariance matrix } \\
\hline 0.5090 & 0.8925 & 0.4924 & -1.3633 & 7.6103 & -2.2186 & 0 & 0 \\
0.3399 & -0.3014 & -0.4005 & 1.8606 & -2.2186 & 4.7472 & -2.5285 & 0 \\
-0.8703 & 0.1303 & 0.5344 & -1.5239 & 0 & -2.5285 & 5.5016 & -2.9731 \\
1.2330 & -0.4236 & -0.5118 & 1.9904 & 0 & 0 & -2.9731 & 8.8210 \\
\hline
\end{tabular}

The calculated value of the goodness-of-fit test statistic $(0.1637)$ is less than the critical value that corresponds to the 0.01 significance level. Therefore, the underlying adjustment appears valid. The calculated values of the Gaussian normal and Pope's $\tau$-test statistics are listed in Table 2.

Table 2: Calculated values of some one-dimensional test statistics

\begin{tabular}{c|c|c|c|c|c}
\hline Observation no. & Residual & $w_{i}$ & $\tau_{i}$ & $\tilde{v}_{i}$ & $\tilde{\tau}_{i}$ \\
\hline 1 & -0.0739 & 0.4046 & 1 & -0.4046 & -1 \\
2 & 0.6852 & 0.4046 & 1 & 0.4046 & 1 \\
3 & 0.0566 & 0.4046 & 1 & 0.4046 & 1 \\
4 & -0.4073 & -0.4046 & -1 & -0.4046 & -1 \\
\hline
\end{tabular}

For purposes of illustration, an artificial outlier of $+20(\mathrm{~m})$ is introduced to the first observation. In this situation, the calculated value of the goodness-of-fit test statistic of 10.5651 is clearly unacceptable; for, 6.6349 is the critical value at the 0.01 significance level. All the observations are flagged as outliers by using the Gaussian normal test at the 0.001 significance level (cf. Table 3). Table 3: Results after outlier simulation of $+\mathbf{2 0} \mathbf{~} \mathbf{m}$ in obs. \#1

\begin{tabular}{c|c|c|c|c|c}
\hline Observation no. & Residual & $w_{i}$ & $\tau_{i}$ & $\tilde{v}_{i}$ & $\tilde{\tau}_{i}$ \\
\hline 1 & -0.5938 & 3.2504 & 1 & -3.2504 & -1 \\
2 & 5.5053 & 3.2504 & 1 & 3.2504 & 1 \\
3 & 0.4550 & 3.2504 & 1 & 3.2504 & 1 \\
4 & -3.2725 & -3.2504 & -1 & -3.2504 & -1 \\
\hline
\end{tabular}

As demonstrated before, in this limiting case of only one redundancy, neither Baarda's w-test statistic nor the standardized LS residual can be used to identify the single outlying observation. Worse still, the calculated value of Pope's $\tau$-test statistic is equal to either 1 or -1 , no matter whether the observations are contaminated by outliers or not. 


\section{Conclusions}

Following the pioneering work by W. Baarda, conventional outlier detection test procedures have been extensively adopted and investigated in geodesy. The test statistics involved in these test procedures include those of Gaussian normal test, Student's t-test, and Pope's $\tau$-test. All these test statistics can be based on Baarda's w-test or the standardized LS residual.

However, in the situation of only one redundancy, (1) Student's t-test statistics are undefined; (2) Pope's $\tau$-test statistics are also invalid, because their absolute values equal to one no matter whether the observations are contaminated by outliers or not; and (3) failure of the global test implies that all the observations will be flagged as outliers and, thus, the Gaussian normal test is inappropriate for the localization of outliers.

A fundamentally efficient approach to control the influence of outliers is based on robust estimation techniques. Obviously, robust estimation methods will perform inconclusively in this limiting case, if the downweighting strategy involved therein is based on any of the aforementioned test statistics.

As a result, without additional information or new observation(s), it is unrealistic to expect that the deteriorating effect of an observation with outlier on the parameter estimates can be reduced in the case of only one degree of freedom.

\section{ACKNOWLEDGEMENT}

This research was sponsored by National Key Basic Research Program of China (2012CB825604), and the Natural Science Foundation of China (Grant Nos. 41474029 and 40874007). The author is also supported by the China Scholarship Council (File No. 2011317045).

\section{REFERENCES}

Baarda W. A testing procedure for use in geodetic networks. Netherlands Geod. Comm., Publ. on Geodesy, 1968, New Series, 2(5), Delft, The Netherlands.

Baselga, S. "Nonexistence of rigorous tests for multiple outlier detection in least-squares adjustment." Journal of Surving Engineering, 137(2011): 109-12.

Brown, R. "A baseline GPS RAIM scheme and a note on the equivalence of three RAIM methods." Navigation, 39(1992): 301-6.

Chatterjee, S., and Hadi, A. Sensitivity analysis in linear regression. New York: Wiley, 1988.

Guo, J. "Analytical quality assessment of iteratively reweighted least-squares (IRLS) method." Boletim de Ciencias Geodesicas, 20(2014): 132-41.

Guo, J. "The case-deletion and mean-shift outlier models: equivalence and beyond." Acta Geodaetica et Geophysica, 48(2013): 191-7.

Guo, J., Ou, J., and WANG, H. "Robust estimation for correlated observations: two local sensitivity-based downweighting strategies.” Journal of Geodesy, 84(2010): 243-250. 
Huber, P., and Ronchettie, M. Robust statistics, 2nd Ed. New York: Wiley, 2009.

Kargoll, B. "On the theory and application of model misspecification tests in geodesy." PhD diss., University of Bonn, 2007.

Koch, K. Parameter estimation and hypothesis testing in linear models, 2nd Ed. Berlin: Springer, 1999.

Kok, J. On data snooping and multiple outlier testing. NOAA Technical Report, NOS NGS. 30, U.S. Department of Commerce, Rockville, MD, 1984.

Langley, R. "The integrity of GPS." GPS World, 10(1999): 60-3.

Leick, A. GPS satellite surveying, 3rd Ed. New York: Wiley, 2004.

Parkinson, B., and Axelrad, P. "Autonomous GPS integrity monitoring using the pseudorange residual." Navigation, 35(1988): 255-74.

Pope, A. The statistics of residuals and the detection of outliers. NOAA Technical Report, NOS 65, NGS 1 Rockville, MD, 1976.

Wolf, P., and Ghilani, C. Adjustment computations: statistics and least squares in surveying and GIS, 3rd Ed. New York: Wiley, 1997.

Recebido em novembro de 2014. Aceito em março de 2015. 